\author{
UNIVERSIDADE DE SÃO PAULO \\ MUSEU DE ARQUEOLOGIA E ETNOLOGIA \\ PROGRAMA DE PÓS GRADUAÇÃO EM ARQUEOLOGIA
}

PEDRAS E TINTAS QUE CONTAM HISTÓRIAS: OS CAÇADORES COLETORES TARDIOS DOS ABRIGOS VERMELHOS, MT

TATIANE DE SOUZA

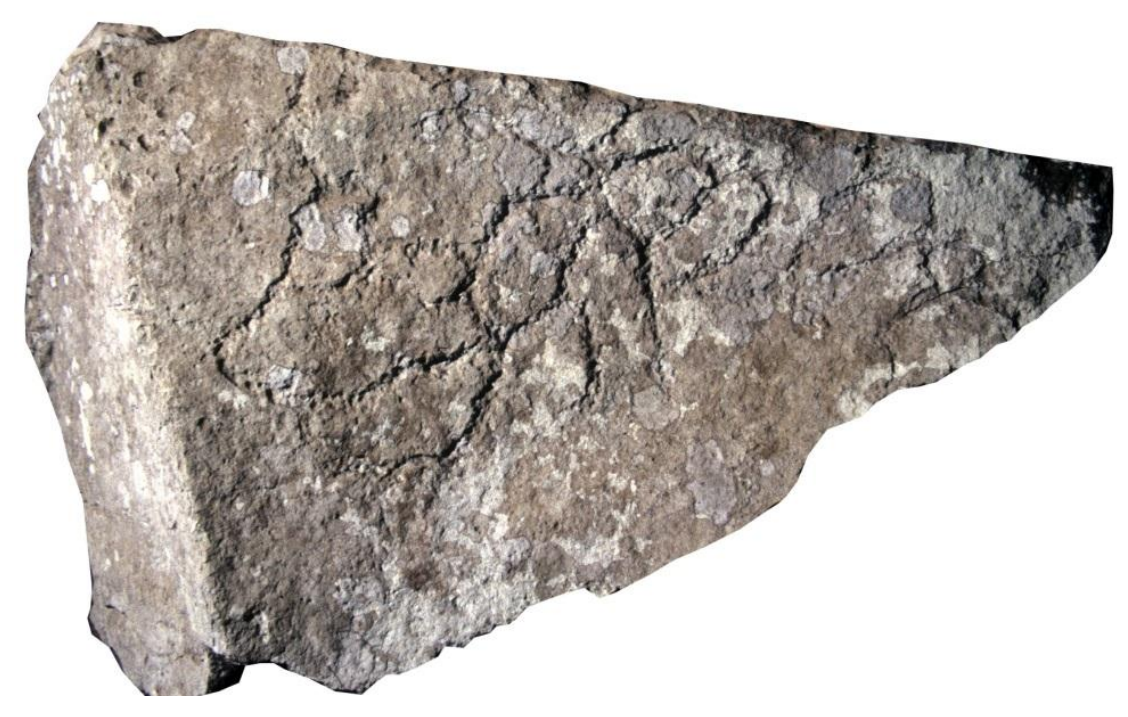

Linha de Pesquisa: Arqueologia e Identidade

São Paulo

2014

Imagem de Capa: Bloco Picotado, alocado no CIII, Painel 3. Foto: D.Vialou 
TATIANE DE SOUZA

\title{
PEDRAS E TINTAS QUE CONTAM HISTÓRIAS: OS CAÇADORES - COLETORES TARDIOS DOS ABRIGOS VERMELHOS, MT
}

\begin{abstract}
Dissertação de Mestrado em Arqueologia para a obtenção do título de Mestre em Arqueologia pela Universidade de São Paulo, Programa de PósGraduação em Arqueologia, Museu de Arqueologia e Etnologia da Universidade de São Paulo.
\end{abstract}

Orientador: Prof. Dr. Paulo DeBlasis

Versão revisada e corrigida

São Paulo 
Dedicatória:

À Maria,

Amor e Gratidãa 


\section{Agradecimentos:}

Meu agradecimento especial é dirigido ao meu orientador Dr. Paulo DeBlasis, pela sua valiosa orientação desde 2007 até o presente, que tornou viável a minha iniciação científica e mestrado, pela dedicação e paciência durante todo o percurso, generosidade e amizade.

Meus agradecimentos institucionais são dirigidos à CAPES - (Coordenação de Aperfeiçoamento de Nível Superior) pelos dois anos de bolsa de estudo concedida a esta pesquisa, a qual se tornou fundamental para a concretização do trabalho.

Agradeço igualmente à profa. Dra. Águeda Vilhena Vialou e ao Prof. Dr. Denis Vialou pela disponibilidade, atenção e respeito dispensados a este trabalho e aos comentários da banca do exame de qualificação que fizeram preciosas observações, a qual participaram as professoras Dra. Águeda Vilhena Vialou e a professora Dra. Maria Mercedes Martinez Okumura. Em momento de conclusão, agradeço à Dra. Cristiana Nunes Barreto Galvão e ao Prof. Dr. Andrei Isnardis Horta que apontaram lacunas importantes que tentei saná-las na medida do possível.

Este trabalho se desenvolveu em várias parcerias e etapas das quais participaram diferentes pessoas. Agradeço a Carlos Alberto Rizzi, (Doutorando em Geografia - USP) pela paciência e respeito pelo tema do trabalho. Agradeço igualmente ao Departamento de Geografia onde aprendi sobre o comportamento das rochas, sobre a geografia estrutural e a importância da paisagem em especial, meus agradecimentos aos laboratórios de Climatologia e Geomorfologia, aos seus professores e alunos.

Agradeço ao Instituto de Matemática e Estatística da Universidade de São Paulo que me revelou uma das mais belas e elegantes ciências, através do qual pude introduzir no meu próprio pensamento a beleza da parcimônia dos métodos quantitativos. Meus agradecimentos especiais são ao professor Dr. Pedro Peixoto, que desenvolveu um programa específico para o tratamento de dados da coleção lítica de Abrigos Vermelhos.

Em segundo momento de pesquisa, agradeço especialmente ao geólogo do Instituto de Geologia da Universidade de São Paulo, Itamar Brancaleon, que direcionou minha aprendizagem sobre o software Surfer 11.0 e a Tatiana Iaconis Pitcher que com seu olhar arguto de geógrafa teve a tenacidade de checar e corrigir incongruências nas imagens e mapas. 
Meus agradecimentos também são dirigidos à Scheila Rotandaro Koch, parceira de caminhada de vida e a Cláudio W. Duarte pela ajuda e senso de humor, para Lygia Ferreira Rocco e Enzo Ferreira Rocco Ribeiro Maciel que se disponibilizaram a me ajudar em minha fase final de elaboração de trabalho, Irmina Doneux Santos por sua capacidade de doação, João Estevam de Argos pelo lirismo necessário, Rodrigo de Lima pelos momentos de descontração e amizade, Juliana Figueira da Hora pela tranquilidade e delicadeza, Lorena Diana Gallo pela lucidez e ao querido Danilo Tabone (in memoriam). Agradeço também a todas as pessoas da Semana de Arqueologia (2013), e a Fernando Ozório de Almeida e Eduardo Bespalez que observaram a cerâmica do sítio.

Dentre os mais próximos, meus agradecimentos expressa a mais profunda gratidão pela família Buarque Falcão. Meus agradecimentos especiais são dirigidos à Fábio Luiz Buarque Falcão, Lucia Buarque Falcão, Diogenes Buarque Falcão, Elisabete Brenda Buarque Falcão, Elder Buarque Falcão, Ana Clarice Buarque Falcão Mesquita e Robson Mesquita.

Por fim, agradeço aos meus amigos de longa data, Michele Silva pela revisão de texto final, Fabiana Medeiros Alves cujos caminhos da fé se tornaram para mim menos preconceituosos, à Érica Marteze Chandelier Pereira que me ancorou com sua praticidade, à Juliana Graciani que me protegeu da perversão humana, a Vagner Antonio da Silva e Bernardo Goldberger pela disposição em ajudar no último momento. 
AD INITIUM

O vento soprava pelo simples prazer de soprar...

Era o tempo em que dávamos o nome primeiro a todas as coisas e cada nome era um poema maduro de símbolos e perfumado de metáforas luzidias. Era, na verdade, o tempo sem os fardos preocupados das filogéneses e ontogéneses, sem conceitos e preconceitos.

Era o tempo em que andávamos nus pintando

símbolos e riscando gravuras sobre as paredes pedra útero das cavernas pelo mágico prazer de criar sem estéticas e as frias racionalidades simplesmente pintar riscar poetar e nada mais...

Namibiano Ferreira Poeta Angolano 


\section{RESUMO}

Esta pesquisa constrói o argumento de que a indústria lítica de Abrigos Vermelhos não corresponde à falta de padronização técnica ou a degeneração das habilidades dos artesãos ocorridas a partir de repertórios tecnológicos líticos do início do Holoceno. Em interface com a Arqueologia de Lugar, a noção de contexto é utilizada para substituir esta argumentação, pela noção de intencionalidade de produção deste conjunto artefatual em meio à relação estabelecida com outros vestígios arqueológicos no sítio, preferivelmente à noção de informalidade, de oportunismo e de irregularidade dos procedimentos técnicos atribuídos habitualmente à produção lítica do período de transição entre horizontes caçadores-coletores e ceramistas.

Palavras chave - Contexto, informalidade lítica, intencionalidade, arte rupestre, abrigo rochoso. 


\begin{abstract}
This research builds the argument that the lithic industry from Abrigos Vermelhos does not correspond with a lack of technical standardization or with the degeneration of the ability of the craftsmen that occurred since the lithic technological repertories of the beginning of the Holocene. Interfacing with the Archaeology of Place, the idea of context is used to replace this reasoning with the idea of intentionality of production of this set of artifacts amidst the stablished relation with other archaeological remains on the site, preferably to the notion of informality, opportunism and unevenness of the technical procedures usually assigned to the lithic production of the transition period between the hunter-gatherer and potter horizons.
\end{abstract}

Key Words - Context, Lithic Informality, Intentionality, Rock Art, Rockshelter. 


\section{Lista de Ilustração}

\section{Lista de Figuras}

1 - Abrigos Vermelhos no Perímetro da Cidade de Pedra 9

2 - Erosão diferencial na Cidade de Pedra 21

3 - Abrigos Vermelhos: Topografias, Fitounidades e Fitogrupos regionais 25

4 - Rio Vermelho e a zona ripária da Cidade de Pedra 27

5 - Fontes de Captação de Recursos Litológicos 30

6 - Posição topográfica de Abrigos Vermelhos. Modelagem de Relevo 32

7 - A microbacia de Abrigos Vermelhos. Modelagem de Relevo 33

8 - Conjunto 1 de Arte Rupestre $\quad 37$

9 - Conjunto 2 de Arte Rupestre 38

10-Conjunto 3 de Arte Rupestre 39

11-Conjunto 4 de Arte Rupestre $\quad 40$

12-Conjunto 4 de Arte Rupestre 41

13-Croqui esquemático da área de escavação de Abrigos Vermelhos 42

14- Laje arenítica na área de contato interna e externa do abrigo 43

15- Camada sedimentar dos Abrigos Vermelhos 44

16- Distribuição dos materiais arqueológicos nas quadras escavadas. $\quad 47$

17 - Quadro de Datações de Abrigos Vermelhos 50

18 - Croqui organizado conforme a ordem cronológica 51

19 - Estruturas de combustão das quadras $13 \mathrm{G}, 17 \mathrm{G}$ e $11 \mathrm{~J}$

20 - Estruturas de combustão das quadras $14 \mathrm{~L}, 13 \mathrm{~L}, 12 \mathrm{~L}$

21 - Estruturas de combustão no setor externo do sítio 55

22 - Perfil estratigráfico do sítio e a distribuição das peças em estratigrafia $\quad 57$

23 - Plano da área de escavação $\quad 58$

24 - Distribuição estratigráfica do sílex $\quad 60$

25 - Distribuição espacial do sílex $\quad 61$

26 - Distribuição estratigráfica do arenito silicificado de fina granulometria $\quad 62$

27 - Distribuição espacial do arenito silicificado de fina granulometria 63

28 - Distribuição estratigráfica do arenito de grossa granulometria 64

29 - Distribuição espacial do arenito de grossa granulometria 65

30 - Distribuição estratigráfica do óxido de ferro 66

31 - Distribuição espacial do óxido de ferro $\quad 67$

32 - Distribuição estratigráfica do óxido de ferro com marca de uso 68

33 - Distribuição espacial do óxido de ferro com marca de uso 68

34 - Distribuição estratigráfica da rocha verde $\quad 69$

35 - Distribuição espacial da rocha verde $\quad 70$

36 - Distribuição estratigráfica dos fragmentos cerâmicos 71

37 - Distribuição espacial dos fragmentos cerâmicos $\quad 72$

$\begin{array}{ll}38 \text { - As remontagens em perspectiva espacial } & 74\end{array}$

39 - As remontagens em perspectiva estratigráfica $\quad 76$

40 - Microsequências de lascamento em sílex e arenito silicificado 81

41 - Análise de PCA (Análise de Componentes Principais) 83

42 - Dendrogramas da análise de agrupamento de sílex e arenito silicificado $\quad 84$

43 - Gráfico com a distribuição das mps, classes e classes de lascas $\quad 88$

44 - Correlações entre os atributos de análise contínuos 91

45 - Frequência e média marginal (mm) C1 Sílex 92

46- Frequência e média marginal (mm) C2 Sílex 93 
47- Frequência e média marginal $(\mathrm{mm}) \mathrm{C} 1$ arenito silicificado

48 - Frequência e média marginal $(\mathrm{mm}) \mathrm{C} 2$ arenito silicificado

49 - Frequência e média marginal $(\mathrm{mm}) \mathrm{C} 3$ arenito silicificado

50 - Frequência e média marginal $(\mathrm{mm}) \mathrm{C} 4$ arenito silicificado

51 - Frequência e média marginal $(\mathrm{mm}) \mathrm{C} 5$ arenito silicificado

52 - Frequência e média marginal $(\mathrm{mm}) \mathrm{C} 6$ arenito silicificado

53 - Frequência e média marginal $(\mathrm{mm}) \mathrm{C} 7$ arenito silicificado

101

54 - Frequência e média marginal $(\mathrm{mm}) \mathrm{C} 8$ arenito silicificado

102

55 - Frequência e média marginal (mm) C9 arenito silicificado 104

56 - Frequência e média marginal $(\mathrm{mm}) \mathrm{C} 10$ arenito silicificado 105

57 - Frequência e média marginal $(\mathrm{mm}) \mathrm{C} 11$ arenito silicificado 106

58 - Frequência e média marginal (mm) C12 arenito silicificado 107

59 - Frequência e média marginal (mm) Rocha Verde 109

60 - Frequência e média marginal Óxido de Ferro 110

61 - Artefatos do conjunto $1 \quad 112$

62 - Desenho de observação 113

63 - Artefatos do conjunto $2 \quad 115$

64 - Detalhes dos gumes dos artefatos do conjunto $2 \quad 115$

$\begin{array}{ll}65-\text { Artefatos do conjunto } 3 & 116\end{array}$

$\begin{array}{ll}66-\text { Artefatos do conjunto } 4 & 118\end{array}$

67 - Detalhes dos retoques do conjunto $4 \quad 118$

68 - Artefatos do conjunto $5 \quad 120$

69 - Face interna dos artefatos B,C,D 120

70 - Desenho de observação 121

$\begin{array}{ll}71 \text { - Desenho de observação } & 121\end{array}$

72 - Artefatos do conjunto $6 \quad 123$

73 - Desenho de observação 123

74 - Artefatos do conjunto $7 \quad 124$

75 - Artefatos do conjunto $8 \quad 125$

76 - Artefatos do conjunto $9 \quad 126$

$\begin{array}{ll}77 \text { - Artefatos do conjunto } 10 & 127\end{array}$

78 - Plaquetas, seixos, blocos e fragmentos de óxido de ferro 129

79- Desenho de observação 129

80 - Frequência do material distribuído nas quadras 143

81 - Distribuição das datações radiométricas em setores $\quad 144$

82 - Média geral da profundidade do material $\quad 145$

83 - Média geral da profundidade da rocha verde e da cerâmica 146

84 - Média geral do sílex, arenito silicificado e óxido de ferro 148

85 - Setor A - Croqui 151

86 - Painel I, CII $\quad 152$

87 - Setor B - Croqui 153

88 - Setor C - Croqui $\quad 155$

89 - Setor D -Croqui 158 


\section{Lista de tabelas}

1 - Medida e peso do sílex

2 - Medida e peso do arenito silicificado de fina granulometria 62

3 - Medida e peso do arenito silicificado de grossa granulometria $\quad 64$

4 - Medida e peso do óxido de ferro 66

$\begin{array}{ll}5 \text { - Medida e peso da rocha verde } & 69\end{array}$

$\begin{array}{ll}6 \text { - Medida e peso dos vestígios cerâmicos } & 71\end{array}$

$\begin{array}{ll}7 \text { - Lista com as remontagens } & 75\end{array}$

8 - Atributos de análise das matérias primas líticas sílex e arenito silicificado $\quad 82$

9 - Distribuição dos materiais líticos $\quad 87$

10 - Classes de análise do material lítico. $\quad 88$

11 - Distribuição das classes de análise das lascas $\quad 89$

12 - Conjuntos líticos conforme os métodos A, B, C 130

13 - Média das classes de análise nominais do método A 131

14 - Média das classes de análise nominais do método B 132

15 - Média das classes de análise nominais do método C 134

16 - Média da ausência de córtex nas matérias-primas líticas 141 


\section{Lista de Siglas}

BAP - Bacia do Alto Paraguai

SDf - Arenito de granulação grossa, feldspática e caulinítica, com níveis e lentes de

conglomerados e estratificações cruzadas planas e largas
N4a - Depósitos conglomeráticos, arenosos e pelíticos

NP2cu - Metaconglomerados polimíticos, meta- arenitos, meta-arcósios, metassiltitos, filitos, microconglomerados, metaconglomerados e metacalcários

CPaq - Sequências sedimentares arenosa com três níveis; superior (arenito com estratificação cruzada), médio (com estratificação cruzada plano-paralela) e inferior (arenitos com lentes de diamictitos)

N1d1 - Zona basal com rochas subjacentes, alteradas, areias, argilas e níveis conglomeráticos parcialmente lateralizados; um zona média concrecionária de lateritos ferriginosos compactos; uma zona superior com solos argilosos 


\section{$\underline{\text { Sumário }}$}

INTRODUÇÃO

1 O LUGAR COMO FOCO DE INTERAÇÃO CULTURAL 11

2 OS ASPECTOS PAISAGÍSTICOS DA CIDADE DE PEDRA 18

2.1 A CIDADE DE PEDRA E AS RELAÇÕES COM AS FORMAÇÕES AMBIENTAIS CIRCUNDANTES

2.2 A CIDADE DE PEDRA E AS RELAÇÕES COM AS FORMAÇÕES AMBIENTAIS INTERNAS 26

2.3 ABRIGOS VERMELHOS E O CONTEXTO DA CIDADE DE PEDRA 32

2.4 SÍNTESE DO CAPÍTULO 34

3 A TEMPORALIDADE E A ESPACIALIDADE DE ABRIGOS VERMELHOS

3.1 A ESTRUTURA FÍSICA DOS ABRIGOS VERMELHOS 36

3.2 A METODOLOGIA DE CAMPO E CAMPANHAS ARQUEOLÓGICAS 45

3.3 AS ESTRUTURAS DE COMBUSTÃO E A CRONOLOGIA DO SÍTIO: QUATRO SETORES DISTINTOS

3.3.1 Setor A: Horizonte cronológico (830+- 50 AP até1470 +-40 AP)

3.3.2 Setor B: Horizonte cronológico (1890+- AP até $2080+-50$ AP) 52

3.3.3 Setor C: Horizonte cronológico ( $545+-55$ AP até $3400+-35$ AP) 53

3.3.4 Setor D: Horizonte cronológico $(3450+-35$ até $4120+-60$ AP) 54

3.4 ESTUDOS DE PROCESSOS FORMATIVOS: HÁ HORIZONTES

CRONOLÓGICOS PRESERVADOS? 60

3.4.1 A distribuição do sílex $\quad 62$

3.4.2 A distribuição do arenito silicificado de fina granulometria 64

3.4.3 A distribuição do arenito silicificado de grossa granulometria 59

3.4.4 A distribuição do óxido de ferro 66

$\begin{array}{ll}3.4 .5 \text { A distribuição da rocha verde } & 69\end{array}$

$\begin{array}{ll}3.4 .6 \text { A distribuição da cerâmica } & 71\end{array}$

3.5 AS REMONTAGENS

3.6 SÍNTESE DO CAPÍTULO 76

\section{PROCESSOS TECNOLÓGICOS NAS MATÉRIAS PRIMAS LÍTICAS}

4.1 CLASSIFICAÇÃO DAS MATÉRIAS PRIMAS LÍTICAS 81

4.2 CLASSIFICAÇÃO TECNOLÓGICA DO MATERIAL LÍTICO DE ABRIGOS VERMELHOS

4.2.1 Análise geral da indústria lítica de Abrigos Vermelhos 87

4.2.2 Correlações entre comprimento, largura e espessura $\quad 89$

4.3 ANÁLISE TECNOLÓGICA DOS CONJUNTOS LITOLÓGICOS 92 
4.3.1 Conjunto 1 de sílex $\quad 92$

4.3.2 Conjunto 2 de sílex $\quad 93$

$\begin{array}{ll}\text { 4.3.3 Conjunto } 1 \text { de arenito silicificado } & 94\end{array}$

4.3.4 Conjunto 2 de arenito silicificado $\quad 95$

4.3.5 Conjunto 3 de arenito silicificado 96

$\begin{array}{ll}\text { 4.3.6 Conjunto } 4 \text { de arenito silicificado } & 97\end{array}$

4.3.7 Conjunto 5 de arenito silicificado $\quad 98$

$\begin{array}{lr}\text { 4.3.8 Conjunto } 6 \text { de arenito silicificado } & 100\end{array}$

$\begin{array}{ll}\text { 4.3.9 Conjunto } 7 \text { de arenito silicificado } & 101\end{array}$

$\begin{array}{ll}\text { 4.3.10 Conjunto } 8 \text { de arenito silicificado } & 102\end{array}$

$\begin{array}{ll}\text { 4.3.11 Conjunto } 9 \text { de arenito silicificado } & 103\end{array}$

$\begin{array}{ll}\text { 4.3.12 Conjunto } 10 \text { de arenito silicificado } & 104\end{array}$

$\begin{array}{ll}\text { 4.3.13 Conjunto } 11 \text { de arenito silicificado } & 106\end{array}$

4.3.14 Conjunto 12 de arenito silicificado 107

$\begin{array}{ll}\text { 4.3.15 Conjunto } 1 \text { de Rocha } & 108\end{array}$

4.3.16 Conjunto 1 de Óxido de Ferro 109

4.4 ANÁLISE ARTEFATUAL 111

$\begin{array}{ll}\text { 4.4.1 Conjunto artefatual } 1 & 112\end{array}$

$\begin{array}{ll}\text { 4.4.2 Conjunto artefatual } 2 & 114\end{array}$

$\begin{array}{ll}\text { 4.4.3 Conjunto artefatual } 3 & 116\end{array}$

$\begin{array}{ll}\text { 4.4.4 Conjunto artefatual } 4 & 117\end{array}$

$\begin{array}{ll}\text { 4.4.5 Conjunto artefatual } 5 & 119\end{array}$

$\begin{array}{ll}\text { 4.4.6 Conjunto artefatual } 6 & 122\end{array}$

$\begin{array}{ll}\text { 4.4.7 Conjunto artefatual } 7 & 124\end{array}$

$\begin{array}{ll}\text { 4.4.8 Conjunto artefatual } 8 & 124\end{array}$

$\begin{array}{ll}\text { 4.4.9 Conjunto artefatual } 9 & 125\end{array}$

$\begin{array}{ll}\text { 4.4.10 Conjunto artefatual } 10 & 126\end{array}$

$\begin{array}{ll}\text { 4.4.11Conjunto artefatual } 11 & 127\end{array}$

$\begin{array}{ll}\text { 4.5 SÍNTESE DO CAPÍTULO } & 130\end{array}$

\section{RETOMANDO AS ESCALAS DE ANÁLISE}

5.1 O SENTIDO DE LUGAR EM DIFERENTES ESCALAS 136

$\begin{array}{ll}\text { 5.1.1Setor A } & 151\end{array}$

5.12.Setor B 152

5.13 Setor C 154

$\begin{array}{ll}\text { 5.1.4 Setor D } & 157\end{array}$

$\begin{array}{ll}\text { 5.2 CONSIDERAÇOES FINAIS } & 158\end{array}$

6 REFERÊNCIAS BIBLIOGRÁFICAS 161

APÊNDICE 1 VARIÁVEIS OBSERVADAS NA INDÚSTRIA L'TICA 179

APENNDICE 2 REMONTAGENS: PERSPECTIVA VERTICAL 180

APÊNDICE 3 FREQUÊNCIAS TECNOLÓGICA DOS CONJUNTOS LÍTICOS 183

APÊNDICE 4 DISTRIBUIÇÃO DAS FREQUÊNCIAS DOS MATERIAIS NAS QUADRAS 


\section{INTRODUÇÃO}

Este estudo trata da cultura material lítica vista em contexto de deposição e associada a outros vestígios arqueológicos no sítio Abrigos Vermelhos, assim como estabelece integração com escalas mais amplas de análise referentes ao contexto paisagístico da Cidade de Pedra.

Parte-se da premissa que este sítio foi visitado ao longo do tempo por diferentes grupos, tendo em vista a longa cronologia e as evidências de mudanças técnicas encontradas na cultura material lítica e na arte parietal. Entende-se que a compreensão do sítio implica em analisar os vestígios arqueológicos em conjunto, e, portanto, estabelecer relações entre o solo de ocupação, o registro rupestre e características da paisagem.

Deseja-se adentrar no arranjo e na organização espacial, identificando os componentes materiais e as relações estabelecidas entre eles a partir destas associações. Estas relações concernem a realizar, para o solo de ocupação, o que já foi estabelecido para a arte rupestre no sítio, ou seja, o mapeamento da diversidade, sucessão e arranjo espacial de processos tecnológicos, conectando-os a possíveis áreas de deposição e, consequentemente, a outros registros arqueológicos.

Abordar a indústria lítica de Abrigos Vermelhos em contexto de deposição traz em seu bojo duas questões amplamente discutidas na arqueologia do planalto central. A primeira refere-se a transição de um horizonte caçador-coletor para ceramista ao longo do holoceno médio em sítios lito-cerâmicos como Abrigos Vermelhos. A segunda está ligada à caracterização de indústrias líticas consideradas de pouca elaboração técnica presentes em abrigos rupestres neste período.

Para o Planalto Central, Robrahn Gonzalez (1996, p.19) afirma que as evidências parecem favorecer a hipótese de continuidade de produção lítica entre estratos acerâmicos e cerâmicos. Corroborando esta exposição, os estudos direcionados para o médio curso do rio Vermelho, sugerem continuidade na produção lítica, interpretados como indicativo de transição, manutenção e estabilidade dos assentamentos pré-ceramistas e ceramistas da área (WÜST, 1990, p.1).

Entretanto, há evidências em contrário, uma vez que estudos realizados no baixo curso do rio Vermelho, no abrigo rupestre Ferraz Egreja, dentro da Cidade de Pedra, indicam ruptura entre níveis estratigráficos acerâmicos e cerâmicos por volta de 2.000 AP (VIALOU, 2006, p.159-161), indiciados por uma série de vestígios materiais líticos e cerâmicos relacionados a intervalos de datações distintas, relativos a fragmentos cerâmicos e materiais 
lítico lascados em quartzito, arenito, sílex e adornos, produzidos em quartzo e óxido de ferro em até 2.000 AP, enquanto outros setores de escavação, em períodos recuados a este, não apresentam material cerâmico, mas possuem quartzito, arenito, sílex e óxido de ferro (VIALOU, 2006, p.160-161).

Esta abordagem contrapõe os trabalhos efetuados até o momento no vale do rio São Lourenço, sob o ponto de vista da cultura material lítica que sugerem a continuidade da produção tecnológica entre grupos caçadores-coletores tardios e ceramistas e a contiguidade ininterrupta dos contextos deposicionais e contato entre ambos. Vale dizer, entretanto, que o contexto de deposição lítica na área de pesquisa é anterior à presença de tradições cerâmicas e uma reflexão sobre estes processos da interação entre caçadores coletores-tardios e ceramistas deve refletir variadas respostas ao período e tipo de contato entre ambos.

A segunda questão concerne à caracterização tecnológica destas indústrias líticas em que o período entre 11.000 e 8.000 AP teria compreendido duas grandes tradições líticas bem definidas do Brasil: a Tradição Umbu no sudeste e sudoeste do país e a Tradição Itaparica na porção central e nordeste (ARAUJO \& PUGLIESE, 2009, p.171). No entanto, ao lado do sistema tecnológico Itaparica, há indústrias líticas baseadas em formas e volumes naturais e de difícil percepção dos estigmas precursores deste sistema tecnológico (LOURDEAU, 2010, p.382).

A indústria lítica de Abrigos Vermelhos encontra sua correlação tecnológica relacionada ao período de transição entre a tecnologia Itaparica e as indústrias do Holoceno médio a partir da fase Serranópolis, com início a partir de 8.500 AP (LOURDEAU, 2006, p.690). Esta indústria lítica foi caracterizada por Pedro Ignácio Schmitz como uma indústria mal definida de lascas irregulares com goivas, bicos, furadores e raspadores pequenos e lascas maiores e mais espessas, desprendidas por percussão (SCHMITZ, 1987, p.34) e de diversos tamanhos (SCHMITZ et al., 2004, p.179).

Estas indústrias pouco definidas cobrem quase completamente o planalto central durante o holoceno médio em abrigos rupestres de Goiás, no Vale do Paranaíba, GO e Alto Araguaia, na Chapada do Parecis e alguns sítios do rio Vermelho em MT (ROBRAHN GONZALEZ, 1996, p.16), com datações que variam entre 8.500 AP, podendo chegar até 4.000 AP em regiões como Caiapônia - GO (SCHMITZ et al., 1986, p.279) e mesmo épocas mais recentes.

Sobre esta caracterização, são aventadas duas hipóteses correlacionadas que explicariam a queda do investimento técnico de produção a partir da fase Serranópolis, culminando num processo de regionalização (BUENO, 2007, p.33; DILLEHAY, 1999-2000 
p.207). A primeira é de cunho arqueológico e seria causado pelo gradual sedentarismo provocado por mudança no modo de vida caçador-coletor para ceramista (Schmitz, 1981, apud, KIPNIS, 1998, p.587; WÜST 1990, p.16), que culminaria na pouca, curta ou variada organização da tecnologia (SCHMITZ, et. al. 1986, p. 280; BUENO, 2007, p.33; RODET, 2006, p.112; FOGAÇA, 2001, p.346). Assim, todo material não enquadrado numa ou noutra tradição lítica foi considerado processo de regionalização (ARAUJO \& PUGLIESE, 2009, p.171). A segunda, pressupõe fatores ambientais, de modo que a regionalização teria suas causas vinculadas às circunstâncias provocadas por alterações climáticas desde o final do Pleistoceno (KIPNIS, 2003, p.583), iniciando um processo de simplificação técnica ocorrida por volta de 9.000/8.000 AP (BUENO, 2007, p.31).

Neste viés interpretativo há um discurso fortemente vinculado a fatores ambientais na definição da queda do investimento técnico na produção de repertórios artefatuais líticos. Destarte, é fato que ainda pouco se conhece ou mesmo se discute as causas ou razões da existência artefatual a partir de sua própria composição, relacionando este decréscimo de aprimoramento técnico aos fatores de interferência externa do meio, como mudanças climáticas. Não obstante, considera-se pertinente introduzir nesta discussão um elemento até o momento pouco considerado perante a existência de repertórios artefatuais líticos de caçadores coletores-tardios: a arte rupestre.

Cientes de que o sítio Abrigos Vermelhos comporta um rico contexto de produção de arte rupestre e que esta pesquisa é direcionada para uma abordagem contextual, não é possível deixar de incluí-la em nossa análise. Líticos e arte rupestre encontram-se em associação a partir de contextos muito antigos de períodos paleoíndio em abrigos rupestres, seguramente há pelo menos $12.000 \mathrm{AP}$, alguns com claras evidências de correlação estratigráfica, como aqueles encontrados por Anna Roosevelt, no sítio Pedra Pintada, no Pará (ROOSEVELT, 1996, p.337-338).

A arte rupestre pintada nos paredões ou gravada em blocos aparece inquestionavelmente apenas a partir de 9.000 e 8.000 AP na Lapa do Boquete MG e na Pedra Furada no Piauí, embora haja evidências da preparação de pigmentos desde 11.000 AP em vários sítios de Minas Gerais, como em Santana do Riacho, Lapa do Boquete, e em Santa Elina, MT (PROUS 1997, p.18; MARTINS \& KASHIMOTO, 2009, p.39). De maneira ampla, nota-se que a produção de grafismos pintados e gravados em lajeados espalha-se pelo planalto central, sendo grande a quantidade de tintas, paletas e moedores datados em níveis anteriores a 5.000 AP (PROUS, 1980, p.163). 
Comparativamente, a arte rupestre permanece um elemento associado à ocorrência do repertório artefatual lítico ao longo do tempo e ocorre concomitantemente às mudanças ocasionadas na queda na produção de artefatos planos convexos da Tradição Itaparica (LOURDEAU, 2010, p.51). Está presente nos primórdios de ocupações pré-cerâmicas em sítios do cerrado, assumindo contornos importantes em relação aos processos de manipulação e domesticação de plantas muito antes do aparecimento dos primeiros grupos ceramistas (PROUS, 1980, p.163), não envolvendo necessariamente a relação imediata e direta entre processo de horticultura e sedentarismo (HORTA, 2009, p.248).

Sobre a questão, é importante destacar que registros arqueológicos distintos durante o holoceno médio começam a apresentam evidências de interações estabelecidas entre si. Embora as pinturas rupestres e os conjuntos líticos da Gruta da Pedra Pintada, PA sejam vistos por Roosevelt $(1991,1992)$ como conectados e pertencentes a um período paleoíndio (PEREIRA, 2003, p.28), tornam-se evidentes as correlações entre os vestígios arqueológicos, em contextos amazônicos como no sítio da Ilha dos Martírios, PA, em que há representações de zoomorfos, antropomorfos, mas também de machados (PEREIRA, 2003, p.117).

Outras evidências apontam para a identificação dos conjuntos rupestres no noroeste do Pará e do material cerâmico, particularmente da cerâmica Tapajós, que revelou uma série de semelhanças temáticas e estilísticas entre os conjuntos rupestres e os motivos representados nesta cerâmica (PEREIRA, 2003, p.232). Por fim, as relações entre conjuntos rupestres e cultura material foram reforçadas no sudeste do Amapá, local em que um fragmento cerâmico encontrado comporta a figura de um antropomorfo (PEREIRA, 2003, p.233).

Assim, vai-se trabalhar neste estudo com a ideia de que os vestígios líticos e parietais encontram-se associados no contexto de atividades que demandam a articulação de ambos os procedimentos, produção lítica e parietal, arte e técnica, chão e parede.

Ao refletir sobre o que poderia significar este aspecto dos conjuntos tecnológicos líticos menos padronizados ou simplificados, cabe dizer que não se faz costumeiramente estudos de material lítico associado às demais dimensões do registro arqueológico ou "aos contextos de deposição que compõem os achados líticos" (HORTA, 2007, p.195), de modo que pensar sobre o nexo que conecta os elementos técnicos do lítico aos elementos técnicos da arte rupestre, é considerar as razões de por que o este repertório artefatual não é ativamente transformado para ser vetor de identidades ou expressar relações simbólicas, tal qual o caso da arte rupestre, produzida para ações intencionais significativas.

Nesta direção, alguns contextos arqueológicos similares de abrigos rupestres com período de ocupação pré-cerâmico e cerâmico estão sendo estudados na porção sul e central 
da África (DONSOW, 1994; THORP, 1996; HALL \& SMITH, 2000; VAN DOORNUM 2007, 2008), produzindo indícios de uma sequência de interações mais complexas do que se supunha para este período. Estes indícios se reportam à troca de informações e conhecimentos sobre estratégias de caça, trabalhos com peles, madeira e produção de arte rupestre, podendo ocorrer a troca de informações sem ocorrer necessariamente o processo de sedentarização (VAN DOORNUM, 2008, p.272).

A partir destas considerações, temos a oportunidade de inquerir em Abrigos Vermelhos se o repertório lítico apresenta traços de uma tecnologia lítica antiga que demonstrem filiações técnicas específicas; se apresenta transições entre uma tecnologia bem elaborada e se estas técnicas se relacionam com a continuidade ou mudança tecnológica na estratigrafia. $O$ foco de estudo recai sobre a conexão mantida entre as atividades líticas e outros tipos de registro arqueológico, tais como estruturas de fogueira e arte rupestre, fornecendo elementos para que seja discutido o uso sucessivo do espaço, assim como contato e relações de ocupações no sítio e áreas adjacentes a ele.

Embora estejamos propensos a ver um aparte espacial entre contextos de produção de arte e lítico, mantendo acentuadas diferenças quanto ao posicionamento específico e ao tratamento técnico, ou seja, enquanto que os materiais líticos ocupam os solos, a arte rupestre permanece isolada e privilegiada do ponto da visualização espacial, deve-se ter em conta que tanto o depósito da arte rupestre quanto do material lítico estão no mesmo lugar, e que, aqueles que visitaram o abrigo podem ter reinscrito significados para estas atividades ao longo do tempo.

\section{A Cidade de Pedra}

As primeiras descobertas arqueológicas constam de 1982, no âmbito de trabalho de uma equipe franco-brasileira composta por pesquisadores do Museu de Arqueologia e Etnologia da Universidade de São Paulo, MAE-USP e do Muséum National d'Histoire Naturelle MNHN- França (VIALOU, 2013, p.13). Esta equipe desenvolve pesquisas sistemáticas há trinta anos na região da Serra das Araras, ao norte e na região de Rondonópolis, ao sudoeste de MT, local onde se situa a Cidade de Pedra. Os objetivos são diversificados tanto do ponto de vista ambiental, quanto no que diz respeito aos vestígios culturais. Desse modo, os interesses dirigem-se para escavações e estudo da arte rupestre, mas também para a geologia, a sedimentologia, a palinologia e antracologia, através da abordagem multidisciplinar que caracteriza o projeto. 
Através de um programa de pesquisa intitulado Pré-História e Paleoambiente no Mato Grosso (VIALOU, 2013, p.13), direcionado para a Cidade de Pedra, o estudo foi programado para que abrangesse uma área restrita e delimitada entre "o rio Vermelho, ao norte, e pelo rio Ponte de Pedra, a leste, pela chapada ou platô com suas culturas ao sul, e a oeste por um vale aberto, separando as áreas do vale das formações rochosas" (VIALOU, 2013, p.14), [figura $1]$.

As prospecções, escavações, sondagens e coletas de superfície em sítios da região mostram a intensidade das ocupações ao longo de alguns milhares de anos, tendo-se atualmente registrados "167 sítios arqueológicos, dos quais 2 são funerários, 158 são abrigos rupestres e 9 são sítios a céu aberto" (TOLEDO, 2013, p.19). No local onde se encontram estes sítios, a paisagem arenítica ruiniforme foi denominada pela equipe de pesquisadores que ali trabalham de "Cidade de Pedra". Esta nomenclatura é derivada das características físicas que o processo de desnudamento erosivo das rochas sedimentares sofreu ao longo dos milênios, causando a impressão de uma paisagem urbana.

A Cidade de Pedra pertence ao município de Rondonópolis, localizado a extremo sudoeste de MT, dentro de uma área aproximada de 16.000 ha, com coordenadas $16^{\circ} 30^{\prime} \mathrm{e} 16^{\circ}$ $35^{\prime}$ de latitude sul, e as coordenadas $54^{\circ} 45^{\prime}$ e $55^{\circ} 55^{\prime}$ de longitude Greenwich Oeste (TOLEDO, 2006, p.28). Estruturalmente está imersa em uma série de estratos areníticos, principalmente derivados da Formação Geológica Furnas (SILVA, 2005, p.56), cuja paisagem apresenta milhares de formas erodidas designadas como morros (VIALOU, 2006, p.51).

Para o baixo rio Vermelho, as datas radiométricas, asseguram um horizonte cronológico bem estabelecido há pelo menos 6.000 AP (WÜST, 1990, p.366), podendo recuar para datações bastante antigas de até 9.500 AP para o sítio Morro Solteiro (FONTUGNE, 2013, p.48-49). Circunscritos a este horizonte, estão os abrigos rupestres Abrigos Vermelhos e Ferraz Egreja, contidos em um período de ocupação de 5.000 anos sem que se note interrupção. É digno de nota que, ambos os sítios são assentamentos sob "a proteção de blocos testemunhos areníticos exibindo no sedimento arenoso uma abundante indústria lítica associada a uma menor quantidade de fragmentos cerâmicos” (DeBLASIS, 1993, p.221).

A arte rupestre nos Abrigos Vermelhos também conserva conexões importantes com outros sítios da Cidade de Pedra, partilhando os padrões descritos para a área, em que são distintas três fases de execução técnica. Dessas três fases, a fase mais antiga é a pictural, composta de sinais e de alguns animais e humanos, sucedida por picoteamento, e, às vezes gravura; e a terceira, composta de traços finos e filiformes, tais como traços de um lápis grosso (VIALOU, 2006, p.56-57). 
Devido às semelhanças encontradas entre a cultura material de Abrigos Vermelhos e o contexto arqueológico que o cerca concernente à deposição de material lítico, cerâmico e de arte rupestre, é possível pensar neste sítio como parte integrada de uma paisagem que fornece evidências materiais de redes espaciais interligadas de pessoas e recursos. Abrigos Vermelhos é um lugar conhecido, visitado e lembrado ao longo dos milênios, revelando o processo de reconhecimento de seu posicionamento na paisagem e modos de organização da cultura material.

O sítio Abrigos Vermelhos situa-se na parte central de um extenso e aplainado patamar, localizado entre o topo da chapada e a escarpa da serra, tendo abaixo os terrenos planos às margens do rio Vermelho (DeBLASIS, 2006, p.145). Corresponde a um conjunto de afloramentos areníticos formados por processos de erosão diferencial, "de cerca de 10 metros de altura com aproximadamente 20 metros quadrados de área abrigada" (PAILLET, 2006, p.91). Além de exibir um importante conjunto de vestígios no solo, apresentam também inúmeros conjuntos de grafismos rupestres em suas paredes, tanto internas como externas.

As escavações arqueológicas foram efetuadas durante a década de 1990, contabilizando cinco campanhas e uma área total escavada de 49 metros $^{2}$, que recuperaram em sua maior parte vestígios líticos lascados, matéria corante, seixos e blocos rochosos sem evidências de lascamento e poucos fragmentos cerâmicos. Este sítio abriga também uma série de fogueiras estruturadas com dimensões e formatos distintos, localizadas tanto na área abrigada, quanto fora dela.

As cerca de 540 unidades gráficas foram detalhadamente descritas do ponto de vista técnico, estilístico e de inserção no suporte (PAILLET, 2006, p.91-94), de modo que, há pelo menos oito técnicas diferentes registradas, sendo o desenho a traço a técnica mais comum. De fato, "lápis" foram encontrados no solo de ocupação. A gravura picoteada é também uma técnica habitual no sítio, embora esteja apenas em alguns painéis, enquanto outras técnicas combinam o picoteamento e ou o desenho e pintura (PAILLET, 2006, p.100).

A presença de cerâmica em abrigos rupestres da região faz parte da problemática das ocupações concomitantes entre abrigos rupestres e aldeias de grupos ceramistas (MONTEIRO, 2006, p.8). Conforme os resultados de análise estabelecidos por Monteiro (1996), os sítios a céu aberto da Cidade de Pedra estão associados à tradição URU e TUPI, enquanto os abrigos sob rocha, Abrigos Vermelhos, Ferraz Egreja, Cipó, Antiqueira e Arqueiros, apresentam uma maior diversidade de características tecnológicas (MONTEIRO, 2006, p.46). 
Nos Abrigos Vermelhos, a partir de uma amostra diminuta de material cerâmico, a análise tecnológica evidencia tempero de fibras vegetais ou de caco moído, com potes pequenos que apresentam lábios arredondados, inclinação fechada e diâmetro máximo de 20 $\mathrm{cm}$, de modo que, comparativamente às características tecnológicas estabelecidas para o sítio Ferraz Egreja, outro abrigo rupestre importante da área, o horizonte de ocupação ceramista de Abrigos Vermelhos poderia recuar até 2.000 AP e as características tecnológicas da cerâmica remeter a outro contexto ambiental que não o núcleo central da Cidade de Pedra, localizado no Pantanal Matogrossense, onde é constatada a presença cauixi, cuja ocorrência não consta no rio Vermelho (Wüst, 1990, apud, MONTEIRO, 2006, p.63).

Tendo delineado a síntese dos principais vestígios arqueológicos e os achados recuperados de Abrigos Vermelhos, tem-se em vista que a cultura material lítica e as estruturas de combustão parecem ser bons indicadores cronoculturais, podendo apresentar diferenças cronoestratigráficas e tecnológicas dentro das áreas interna e externa do abrigo, podendo evidenciar diferenças no uso do espaço e apontar para relações entre ocupações, grupos e tecnologias distintas. 

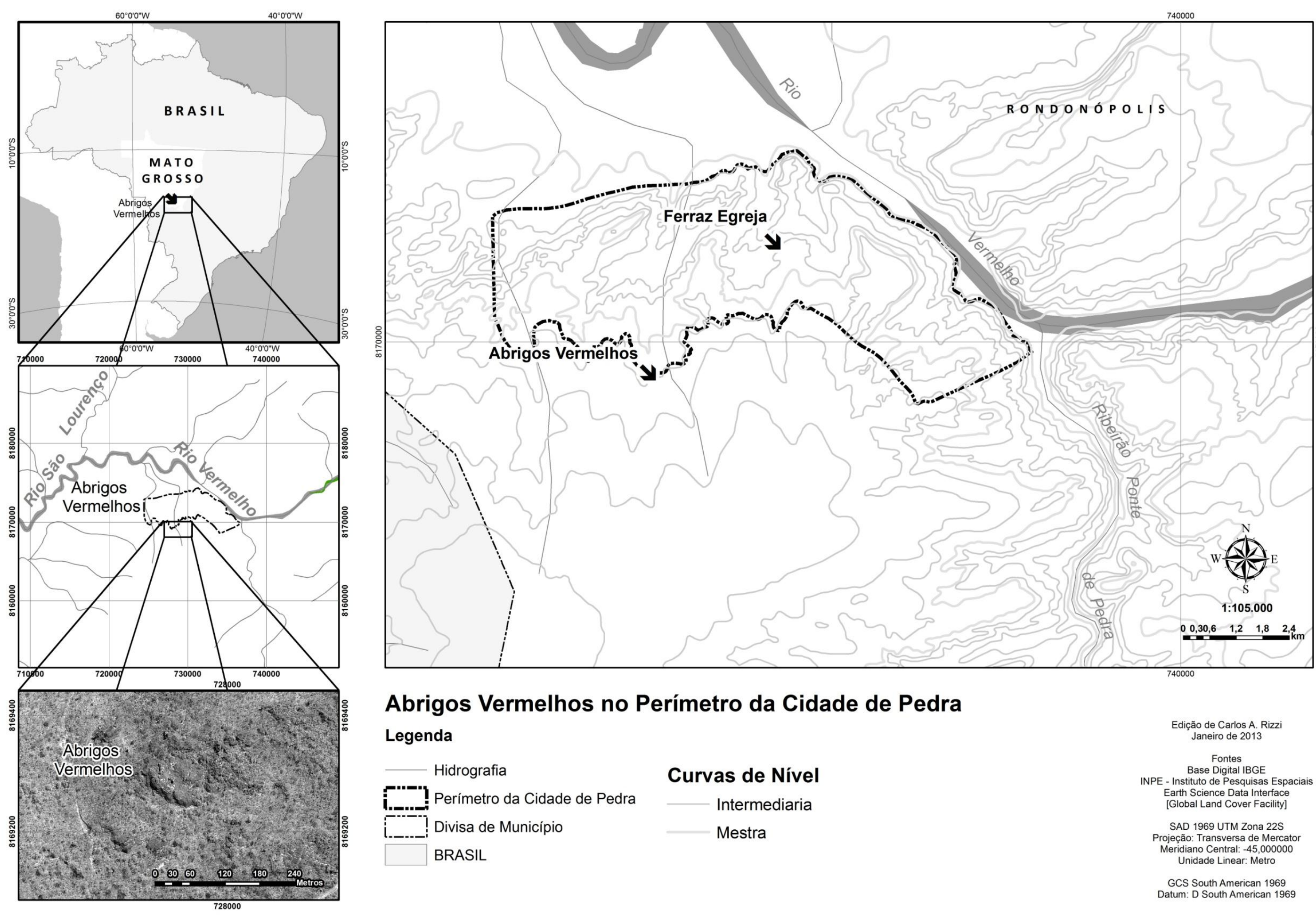

\section{Abrigos Vermelhos no Perímetro da Cidade de Pedra}

Legenda

Hidrografia

Perímetro da Cidade de Pedra

Divisa de Município BRASIL

\section{Curvas de Nível}

Intermediaria

Mestra
Edição de Carlos A. Rizzi Janeiro de 2013

Fontes

INPE - Instisto digheal IBGE Espaciais Earth Science Data Interface
[Global Land Cover Facility]

SAD 1969 UTM Zona 22S Projeção: Transversa de Mercator Meridiano Central: - 45,000000
Unidade Linear: Metro

GCS South American 1969 
Partindo desta premissa, estabelecemos como proposta de pesquisa a análise da tecnologia lítica vista em contexto de deposição e de articulação com a paisagem dos Abrigos Vermelhos, de modo a considerar a hipótese se uma tecnologia lítica mais refinada e antiga torna-se menos refinada com o tempo, ou trata-se de um padrão tecnológico homogêneo com variações relacionadas ao uso do sítio e sua localização na paisagem? Além disso, procura-se por indícios sobre como o padrão tecnológico se relaciona a outros vestígios arqueológicos presentes no abrigo e como estas relações evidenciam mudanças no sentido que o lugar apresenta ao longo do tempo.

As questões deste estudo se desdobram em diferentes escalas de análise com alcances distintos. A escala permite relacionar o objeto de pesquisa em diferentes níveis. No capítulo I, são delimitados os preceitos teóricos e metodológicos que norteiam os rumos da pesquisa, enquanto o capítulo II traz o estudo da fisiografia regional da Cidade de Pedra no que se refere à geologia, à topografia e à vegetação, tentando abandonar a ideia de entorno ambiental de um sítio arqueológico como cenário ou pano de fundo, passando a vê-lo como elemento de escolha e determinação dos elementos naturais que melhor servem aos interesses de grupos sociais em suas redes de comunicação, caminhos e recursos. Em seguida, o capítulo III versa sobre o sítio arqueológico, considerando a descrição de suas características estruturais, a documentação de campo sobre o processo de escavação e análises que incluem o material arqueológico em estratigrafia. Esta escala de análise avança no exame e na construção de uma cronologia cultural para o sítio. O capítulo IV é a análise das técnicas empreendidas nas matérias-primas líticas e dos processos técnicos de produção em cada uma delas. O capítulo V de certo modo, conecta todas as escalas de análise e concentra boa parte dos esforços empreendidos neste trabalho no sentido de desenvolver o propósito de trabalhar o espaço interno do abrigo como local de interação entre atividades e registros arqueológicos distintos, quase sempre tratados separadamente. 


\section{Capítulo I}

O sagrado e o profano podem não ser sempre reproduzidos através de esferas separadas

(BRÜCK \& GOODMAN, 1999, p.4)

\section{O LUGAR COMO FOCO DE INTERAÇÃO CULTURAL}

Ao longo da história da arqueologia a unidade de análise fundamental é o sítio arqueológico. A definição de sítio arqueológico pode ser compreendida de diferentes modos. Através do século XIX aumentou o interesse a respeito dos materiais arqueológicos descobertos e sobre a variação cultural que derivavam destes achados, elaborando cronologias dos sítios e assim determinando quais elementos eram sincrônicos e quais eram diacrônicos (TRIGGER, 1989, p.156). Durante o século XX esta concepção modificou e sítios arqueológicos foram compreendidos como lugares fixos na topografia onde o homem poderia periodicamente pausar e executar ações (BINFORD, 1982, p.6), ou ainda, ser considerado como um locus geográfico, articulado de atividades humanas e associado a conjuntos de estruturas (CLARKE, 1977, p.11). Atualmente, o sítio arqueológico também é visto dentro de uma escala fenomenológica, o qual seus ocupantes dão significados a suas vidas através de sua materialidade e atividades técnicas construídas (DOBRES, 1999, p.172).

Estas definições interferem na compreensão de como sítios arqueológicos são interpretados em função de seus conjuntos artefatuais e de relações mantidas com seus arredores, de modo que os traços da presença humana, explicam-se, ou por meio da atuação de grupos distintos dentro de um mesmo espaço, ou por diferentes atividades praticadas por um mesmo grupo dentro do mesmo espaço (WARGO, 2009, p.40). No primeiro caso a variabilidade artefatual foi relacionada à recorrência e constância de ocupação de um sítio pelo mesmo grupo, enquanto no segundo foi relacionada aos traços deixados dentro de um sítio ou conectada a um sistema maior que integram vários sítios às atividades de mobilidade dentro de uma rede territorial. Esta problemática faz parte de um debate estabelecido na década de 1960 entre Lewis Binford e François Bordes, denominado debate mousteriense. Este debate travado na década de 1960, entre o arqueólogo americano Lewis Binford e o 
arqueólogo francês François Bordes e pode ser sintetizado como uma ampla diferenciação de significado e interpretação dos conjuntos artefatuais líticos durante o Paleolítico Médio.

Isto posto, a definição de sítio arqueológico enquanto lugar é crucial para este trabalho. Considera-se que um lugar atinge realidade concreta "quando temos experiência dele" (TUAN, 1983, p.21). Definido de outra maneira, é um locus de convivência das pessoas com o mundo material, de modo que a "extensão de horizontes começa em um lugar e se estende para outros lugares" (ZEDEÑO, 2000, p.106). A partir destas considerações este trabalho se apoia em princípios teóricos e metodológicos que exploram a articulação entre a experiência com o lugar e a extensão do lugar na paisagem (BINFORD, 1982, p.6; CASEY, 1996, p.25, ZEDEÑO, 2000, p.106).

É digno de nota que nesta abordagem os pesquisadores reconhecem que o sítio arqueológico abrange uma extensão maior com seu entorno que o próprio locus de atividades concentradas. Assim, "atalhos, estradas e caminhos foram reconhecidos como lugares em seus próprios termos, com intercurso social e associações na cultura material" (ZEDEÑO \& STOFLE, 2003, p.59).

A arqueologia de Lugar é uma ferramenta teórica metodológica que propõe metodologias de organização do espaço interno de um sítio arqueológico e do ambiente que o cerca, sugerindo que seja substituído o conceito de espaço como uma unidade de análise abstrata pelo conceito de lugar, ou a constatação de que indivíduos ou grupos desenvolvem relações de interdependência com lugares e recursos (ZEDEÑO \& STOFLE, 2003 p.61), e por isto, foi definida como ferramenta para o entendimento dos recursos líticos vistos em diferentes resoluções.

Delimitado os princípios gerais que norteia o trabalho, o objeto de pesquisa está direcionado para o entendimento da materialidade existente no espaço interno de Abrigos Vermelhos e a materialidade existente em seu entorno imediato conectadas por diferentes escalas de análise. Modelos interpretativos de paisagem pressupõem que a relação entre o homem e a natureza se faz através de escalas de análise (ZEDEÑO, 2000, p.102).

A escala de análise neste estudo é compreendida operacionalmente como uma "relação entre unidades de análise que delimitam fenômenos e designam a abrangência ou hierarquia entre estes fenômenos" (DUNNELL, 2007, p.189), mas compartilha da perspectiva teórica em que o conceito de escala é compreendido no sentido exposto por Dobres (1999, p.142-145), referindo-se os traços físicos que envolvem os agentes pré históricos, traçando suas ações materialmente. 
Deste modo, o mergulho na microescala requer o entendimento da macroescala e de seus processos transformativos (Marquardt, 1992, apud, DOBRES 1999, p.129), dividindo a hierarquia ou abrangência de fenômenos em três escalas de análise. A primeira escala descreve a fisiografia regional da Cidade de Pedra. A descrição da fisiografia regional da Cidade de Pedra apresenta o propósito de entender seu posicionamento em relação ao seu entorno regional e de Abrigos Vermelhos em relação à Cidade de Pedra e coloca no centro da discussão o conceito de estrutura, concebido como "o meio e o resultado da interação social e recursos materiais disponíveis para indivíduos e grupos" (DOBRES \& HOFFMAN, 1994, p.222).

Os recursos analíticos para a operacionalização desta escala foi a utilização de uma base documental cartográfica digitalizada e disponibilizada pelo IBGE, INCRA, RADAMBRASIL e PROJETO SIVAN. Foram consultadas cartas geográficas em escala de 1:100.000, em formato vetorial da área de pesquisa, respectivamente: Folha SE 21 - XB-I Fazenda Prata, Folha SE 21- XB-II Rondonópolis, Folha SE 21 - XB -IV Fazenda Taiamã, Folha SE 21- X-BV Anhumas. Esta análise resultou na organização das informações geográficas a partir do uso do software ArcGIS e do aplicativo ArcSCENE para a modelagem de relevo. A cartografia digital apresentou-se como uma alternativa eficaz, permitindo detectar, localizar e representar de maneira eficiente os recursos naturais e promover a organização do espaço.

A segunda escala de análise é concernente ao estudo estrutural do sítio arqueológico e do arranjo espacial dos elementos registrados e ou recuperados no momento da escavação. Esta escala explora a homogeneidade ou heterogeneidade do depósito arqueológico e analisa a continuidade ou mudança nos estratos estratigráficos em busca por evidências de eventos. Eventos são considerados neste trabalho pontos no espaço que podem ser isolados em relação às coordenadas $\mathrm{x}, \mathrm{y}$, mas, que introduz a dimensão tempo, marcada pela análise da profundidade (z), fornecendo sentido à estrutura (DOBRES, 1999, p.165).

Como procedimentos analíticos foram realizadas análises de movimentação vertical e horizontal das peças em estratigrafia e da área escavada a partir do software GOLDEN SURFER 11.0, testando a influência do peso e do tamanho das peças sobre um eventual processo de dispersão horizontal e movimentação vertical. O método de estimativa para modelagem de superfícies escolhido foi a triangulação linear. Este método de análise gera mapas de contornos e pontos derivados do padrão original dos dados, de modo que as estimativas produzidas, limitam-se à área amostrada, não extrapolando as informações de dados originais em mapas de estimativas dos dados (LANDIM et. al., 2002, p.2). 
Além disso, foram realizadas remontagens que suprem informações precisas sobre o comportamento da movimentação horizontal e vertical das peças. A remontagem é o método de análise que coloca mais precisamente a perspectiva de isolamento de áreas de atividades (ARAUJO, 1995, p.5; HOFMAN, 1992, p.1; VILLA, 1982, p. 279), buscando compreender a distribuição espacial e vertical das peças, provendo uma medida comparativa do padrão, intensidade ou duração de ocupação do sítio (HOFMAN, 1992, p.1).

A terceira escala de análise é do estudo da manufatura dos artefatos líticos e perpassa pelo estudo do repertório artefatual lítico sob o ponto de vista do discernimento das técnicas empregadas. A perspectiva teórica metodológica adotada inclui a análise dos materiais líticos, considerando as decisões que concernem às sequências de produção destes artefatos, mas também inserem questões a respeito do contexto social que estrutura e fornece significado a eles (DOBRES, 1999, p.164).

Nesta direção, a primeira questão envolve a necessidade de delimitação de um método que sistematize este repertório artefatual, denominado expediente e caracterizado até o momento pelas curtas sequências de lascamento, pela extração de matérias-primas abundantes de contextos circundantes e pelo aproveitamento de matérias-primas sem transformação intensiva (BUENO, 2007, p.32).

A partir desta caracterização, propõe-se para o estudo da indústria de Abrigos Vermelhos a articulação entre as características físicas das matérias-primas e as sequências de lascamento, realizando a classificação de conjuntos litológicos segundo parâmetros de observação macroscópicos das texturas das rochas, para, em seguida, descrever a tecnologia do material lítico contido no interior destes conjuntos litológicos, segundo o método da chaînes operatóires. O principal aspecto neste sentido é a tentativa de reunir séries de lascamento maiores que cada microsérie de lascamento em si, mas não tão generalizantes a ponto de se perder processos técnicos de lascamento peculiares.

Partir da classificação da matéria-prima e não da tecnologia foi um caminho escolhido para articular as curtas sequências líticas da coleção. Uma situação comum na Arqueologia é definir o que é significativamente relevante para uma classificação. Uma decisão deste porte implica o que classificar e a definição de uma estratégia de classificação, e, por consequente, que a classificação é a pedra angular da sistematização arqueológica (DUNNELL, 2007, p.67).

Para realizar a classificação das matérias-primas líticas, organizamos uma estrutura de análise pautada nas características macroscópicas da textura das rochas sedimentares clásticas (arenitos silicificados) e a estendemos às rochas sedimentares não clásticas (sílex), realizada 
em lupa binocular com resolução de 40 vezes de aumento. Foi assumida como definição de textura, "o aspecto físico e o arranjo dos componentes das rochas sedimentares, no que diz respeito ao tamanho, forma e disposição (orientação e aglutinação) dos grãos ou partículas, portanto, trata-se do aspecto físico da rocha" (SGARBI, 2012, p.310).

Nesta perspectiva, adentramos minimamente no universo dos artesãos que aprenderam a sentir as características das rochas para "prever seu comportamento e selecionar as matériasprimas levadas aos sítios arqueológicos a partir dos atributos físicos macroscópicos" (ARAUJO 1991, p.108). Tom Miller (1972) já alertava que fazia muita falta ao estudante de tecnologia lítica um estudo científico sobre o comportamento das rochas.

Esta análise foi realizada com a ferramenta matemática da análise de agrupamento ou cluster, gerada no software SPSS. O princípio básico de aplicação da análise de agrupamento é que, quanto menor a distância euclidiana, maior tonar-se a afinidade entre os subconjuntos, até que se forme um conjunto total que englobe todas as peças. Este tipo de análise tem em vista a tentativa de explicar conceitos de homogeneidade e separação sob o ponto de vista matemático e leva em consideração diferentes critérios de análise (EVERITT et. al., 2001, p.7).

Após a organização das matérias-primas líticas em uma classificação litológica, utilizamos o método das chaînes opératoires para organizar e descrever a tecnologia lítica. A chaîne opératoire é uma estratégia particularmente útil para identificar e descrever em detalhamento empírico a sequência de estágios técnicos (DOBRES, 1999, p.165).

Desta forma, o interesse de análise é o mais elementar possível e refere-se à detecção de técnicas que podem ser definidas como um encadeamento de ações pré-estabelecidas que se conecta a um método de lascamento (TIXIER et. al., 1992, p.106). Um método de lascamento ordena uma sequência de ações executadas de modo relativamente planejado e integra um sistema técnico ou a análise da interdependência de vários subsistemas ligadas a específicas atividades (TIXIER et. al., 1992, p.12).

O princípio operacional é a detecção de sequências de produção e a detecção dos suportes de produção. Por meio do reconhecimento do suporte é possível revelar o objetivo do artesão (DeBLASIS, 1988, p.77; FOGAÇA, 2001, p.113). A definição de suporte é importante para entendermos o que exatamente procuramos. O suporte pode ser definido como um elemento sobre o qual um objeto é talhado ou lascado (TIXIER et. al., 1992, p.76), ou fornece informações sobre um sistema de debitagem, relacionado à exploração de um núcleo (Boëda, 1997, apud, VIANA, 2005, p.20), revelando a história de produção tecnológica e de confecção de instrumentos (VIANA, 2005, p.18). É pertinente lembrar que a 
debitagem pode ser caracterizada pela obtenção de uma lasca que servirá como suporte da produção de um artefato, enquanto a façonnage pode ser caracterizada como a etapa de estruturação volumétrica da peça (LOURDEAU, 2010, p.74), enquanto o retoque é considerado a etapa de finalização do artefato (TIXIER et. al., 1992, p.67).

Procura-se nesta terceira escala de análise que esta seja uma ferramenta que sirva à exploração do contexto social sem que se generalize processos sociais somente a partir dos procedimentos técnicos executados nas matérias primas líticas. Sob esta perspectiva, o conceito de técnica vem se ampliando nas últimas décadas, como por exemplo, quando considerado que não há separação da esfera comunicativa do comportamento técnico da esfera da produção de identidade (Ingold, 1993, apud, DOBRES, 1999, p136).

Também é necessário sublinhar que esta concepção é oriunda do salto qualitativo na abordagem conceitual que a tecnologia vem sofrendo nas últimas décadas. Primeiramente, o conceito de técnica, processo técnico e intenção técnica tem se alargado nas décadas posteriores à introdução das chaînes opératoires por aqueles que fazem uso da Antropologia da Tecnologia (SORESSI \& GINESTE, 2011, p.335-336), de modo que esta desvincula a produção artefatual de um pensamento unicamente evolucionista (WHITAKKER, 1994, p.58).

Não obstante, é também necessário refletir sobre o alcance deste método. A partir de uma abordagem que considera as habilidades estabelecidas entre as técnicas humanas e as matérias-primas, ele deixa pouca margem à compreensão do artefato fora de uma perspectiva que considera um design pré-estabelecido (INGOLD, 2001, p.18). Além disso, os mesmos atributos de análise podem ser produzidos por meio da utilização de diferentes métodos (BOËDA, 2006, p.38-43), de maneira que a discriminação dos procedimentos técnicos, tornam-se em certa medida, subjetiva quando não há uma sequência de lascamento muito clara (SULLIVAN \& ROZEN, 2009, p.307).

Cientes destas limitações, ainda assim é útil trabalhar com este tipo de metodologia em indústrias líticas como a de Abrigos Vermelhos, tidas como expedientes ou "sem um aparente projeto de redução e preparação de um núcleo" (TIXIER, et. al., 1992, p.46). Em Abrigos Vermelhos temos a quase completa ausência de núcleos, e, dentre aqueles recuperados, há pouca informação devido ao esgotamento ou ao processo de fragmentação térmica, de modo que a coleção é significativamente composta por produtos de debitagem e de façonnage, reduzindo nosso estudo às séries de lascas e aos próprios artefatos.

As informações advindas deste tipo de vestígio são valiosas, tendo em vista que é preciso considerar que a debitagem é um processo redutivo, de modo que as observações das 
séries de lascas são importantes para a discriminação de tipos de núcleos, tipos de técnicas, controle, pré-determinação e reduções próprias às indústrias líticas particulares. Os atributos da análise tecnológica estão contidos no APÊNDICE 1.

Por fim, observamos as relações com o conjunto de representações gráficas a partir dos processos de redução do óxido de ferro e de relações estratigráficas no solo de ocupação. Ampliamos a noção de participação da cadeia operatória lítica, introduzindo o instrumental de produção de arte neste processo, reafirmando que rotinas de gestos técnicos que transformam um material lítico de pouca transformação ou usado in natura em recurso altamente cultural, mantém um sentido de encadeamento organizado de produção, tal qual em outras matérias primas líticas.

É importante ressaltar que tanto a produção lítica quanto a arte rupestre parece ser executadas em pequenas sequências ou fases, de modo que os dados fornecidos pela tecnologia lítica e os dados fornecidos pela arte rupestre são similares quanto à sequência de produção. $\mathrm{O}$ estudo do conjunto de representações gráficas indica que estas não foram realizadas em apenas uma fase e apenas um único período (VIALOU, 2003, p.496), e que as fases de execução de atividades rupestres são consideradas de pouca duração (VIALOU, 2006, p.128), sendo atribuída à arte rupestre, uma característica detectada nos materiais líticos, ou curtas sequências de produção.

A partir desta perspectiva, realizar análises do material lítico em cada escala de análise é um procedimento de análise metodológica que abre espaço para a sua retomada posterior em conjunto. Pretende-se que seja um instrumento que valide através de descrições de contextos espaciais do entorno do sítio, através de testes específicos das áreas de atividades no sítio e de discriminações tecnológicas e conexões com outros vestígios arqueológicos, reflexões sobre a ocupação do sítio e do sentido atribuído ao lugar ao longo do tempo. 


\section{Capítulo II}

Nada que seja visível é entendido pelo sentido da visão isoladamente, salvo a luz e as cores.

(Alhazen 1038 d.C., apud, GOMBRICH, 1995, p.16)

\section{OS ASPECTOS PAISAGÍTICOS DA CIDADE DE PEDRA}

\subsection{A CIDADE DE PEDRA E AS RELAÇÕES COM AS FORMAÇÕES AMBIENTAIS CIRCUNDANTES}

Este subcapítulo discriminará os aspectos estruturais do posicionamento da Cidade de Pedra em relação ao seu entorno imediato em função dos aspectos geoestruturais. A contextualização da Cidade de Pedra procura colocar em evidência o contato com áreas circundantes e potenciais relações apontadas pela cultura material a partir da presença de matérias-primas, quiçá alóctones, ou, comprovadamente alóctones. Procura-se relacionar a Cidade de Pedra às suas cercanias mais altas representadas pelo Planalto dos Alcantilados, mas também às suas áreas mais baixas, incluídas na bacia do São Lourenço.

Concorda-se com o fato de que a história de ocupação humana de uma área não se concebe em torno de construções de lugares sozinhos, específicos, herméticos ou desprovidos de materialidade, mas sempre está sob a condição de uma situação integradora (BERLEANT, 1992, p.12). Deste modo, procura-se pinçar elementos materiais que permitam atribuir à Cidade de Pedra um espaço cujas forças culturais exibem um papel em como vemos o ambiente e como agimos nele.

Embora, dentro da tradição científica ocidental, desde o século XVIII o espaço tem sido considerado o da física e o da matemática, ou, o da razão pura, medido por padrões universais em dimensões como distância, tamanho, forma e volume (BECK, 1967, p.21), a definição de espaço abre precedente para a concepção de uma forma híbrida entre natureza e cultura como primeiro passo de intersecção entre repertórios técnicos humanos e sua composição ambiental.

Para considerar a região da Cidade de Pedra como uma unidade física particular, é necessário primeiro ter em vista o que a cerca, e, neste sentido, é preciso abranger a macrounidade da qual a Cidade de Pedra é constituinte, ou a Bacia do Alto Paraguai, (BAP). Aziz Ab'Saber (2010), já explicitava que o estudo das superfícies aplainadas em uma 
província geomorfológica, tal qual o caso da Bacia do Alto Paraguai, auxilia substancialmente a compreensão da história fisiográfica regional de um determinado lugar (AB'SABER, 2010, p. 494).

A Bacia do Alto Paraguai é parte integrante da Bacia do Prata, com uma área estimada de $466.000 \mathrm{~km}^{2}$, compartilhada pelo centro oeste brasileiro e nordeste do Paraguai (AYRES, 2004, p.35). Em território brasileiro, a área é de $363.442 \mathrm{~km}^{2}$, sendo circunscrita ao MS e MT, e se divide em duas porções: uma superior planáltica e outra inferior de planície (AYRES, 2004, p.35).

O principal rio que a banha é o rio Paraguai, nascendo na Chapada dos Parecis e apresentando a maior parte de sua extensão contida dentro dos estados do MT e MS, compreendendo cotas acima de 200 metros para suas porções planálticas e uma significativa área de deposição de sedimentos aluviais recentes em sua porção pantaneira, que avança em direção à Bolívia e ao Paraguai, com altitudes que oscilam entre 100 a 150 metros (ROSS, 1995, p.64).

Segundo Adámoli (2000) é a topografia que condiciona a maior parte dos processos regionais nesta região. Não obstante, é importante observar que para o centro oeste não há uma separação nítida nos divisores de água, fazendo com que as drenagens das diferentes bacias estejam próximas umas das outras (AZEVEDO \& MONTEIRO, 2003, p.5), apontando que os marcos naturais das áreas de contato entre planalto e planície não são claramente definidos, sendo as características de solo e de vegetação importantes parâmetros na complementação de definições de fronteiras naturais (SILVA \& ABDON, 1998, p.17041705).

Nesta pesquisa, as relações fisiográficas da Cidade de Pedra concernem às áreas de planície do Pantanal mato-grossense e das chapadas que a cercam. O Pantanal matogrossense está ladeado ao norte e ao sul por uma série de composições geológicas serranas e planálticas. A porção norte é composta pela Província Serrana, divisora de águas entre as bacias dos rios Cuiabá e Paraguai, participantes da bacia hidrográfica do Paraná; e dos rios Arinos e Teles Pires, pertencentes à bacia hidrográfica do Amazonas (ROSS, 1991, p.21).

A porção sudoeste é delimitada pelos interflúvios intermediários elevados do planalto do Alto São Lourenço-Itiquira-Taquari (AB’SABER, 2010, p.494), cujos limites são marcados pelas bordas escarpadas, correspondente à frente de cuestas, denominada localmente de Serra de São Jerônimo (PINTO, 1988, p.81). A unidade de relevo de maior interesse é a porção sudoeste do Pantanal Matogrossense, relacionadas às porções das terras 
altas na região leste, direção do norte para o sul, que inclui o planalto dos Alcantilados (AYRES, 2004, p.25).

O planalto dos Alcantilados é formado por um conjunto de relevo muito dissecado, elaborado em litologias da Formação Aquidauana e da Formação Ponta Grossa que originou patamares estruturais em diferentes níveis altimétricos que está articulado ao sul com o Planalto Taquari, a oeste com a Chapada dos Guimarães, e a leste adentra o estado de Goiás (NÁPOLIS, 2010, p.35). A área comporta uma série de afloramentos litológicos, de onde pode ser proveniente parte das matérias-primas encontrada dentro dos sítios da Cidade de Pedra, composta por seixos transportados ao longo do rio Vermelho.

Abaixo do Planalto dos Alcantilados está a Depressão de Rondonópolis, com cotas de 300 a 500 metros (AYRES, 2004, p.25-28). Esta é a unidade geoestrutural a qual a Cidade de Pedra está diretamente vinculada. A Depressão de Rondonópolis apresenta diferentes critérios geográficos, cujo maior interesse para este estudo é a existência da Formação Geológica Furnas.

É a formação geológica Furnas que estrutura a maior parte dos processos geológicos atuantes na região da Cidade de Pedra. Geomorfologicamente, é resultante de um intenso fraturamento que causou erosão na forma de cuestas, escarpas de falha e morros testemunhos, de modo que os arenitos formam relevos residuais e erosão diferencial ao longo das fraturas, onde estratificações cruzadas são amplamente avistadas (AUBRY, 2006, p.21). Situada em cotas inferiores a 300 metros, esta região encontra-se abaixo da Formação Ponta Grossa, sendo composta por arenitos de granulação grossa e média com grau incipiente ou parcialmente silicificado, além de importantes descontinuidades físicas e variações granulométricas (SILVA, 2005, p.43).

Este conjunto morfoestrutural formado por patamares estruturais escalonados, topograficamente compreendidos como uma área pedregosa de maior declividade com ilhas de vegetação circunscrita e específica de áreas rochosas (AZEVEDO \& MONTEIRO, 2003, p.32), recebeu o nome de Cidade de Pedra pelos pesquisadores que ali trabalham há 30 anos. Este local pode ser considerado uma vertente com patamares elevados e áreas de planícies em sua base, o que lhe confere um padrão de inserção condizente em relação a outras regiões da BAP, estando imersa em meio a uma série de formações geológicas semelhantes do cerrado brasileiro que compreende a configuração planalto-vertente-planície.

Nesta localização ocorre um acentuado processo de desnudamento e erosão, o qual esculpe formas pelo desgaste e traz à tona uma série de formas erodidas designadas em solos e mantos de alteração, notadamente em regiões submetidas a clima tropical úmido (SGARBI, 
2012, p.329). O processo de desnudação na região da Cidade de Pedra é um fator bastante acentuado e um fator relevante para a caracterização dos aspectos visuais e sensoriais, quando se observa seus morros testemunhos esculpidos formas diversas.

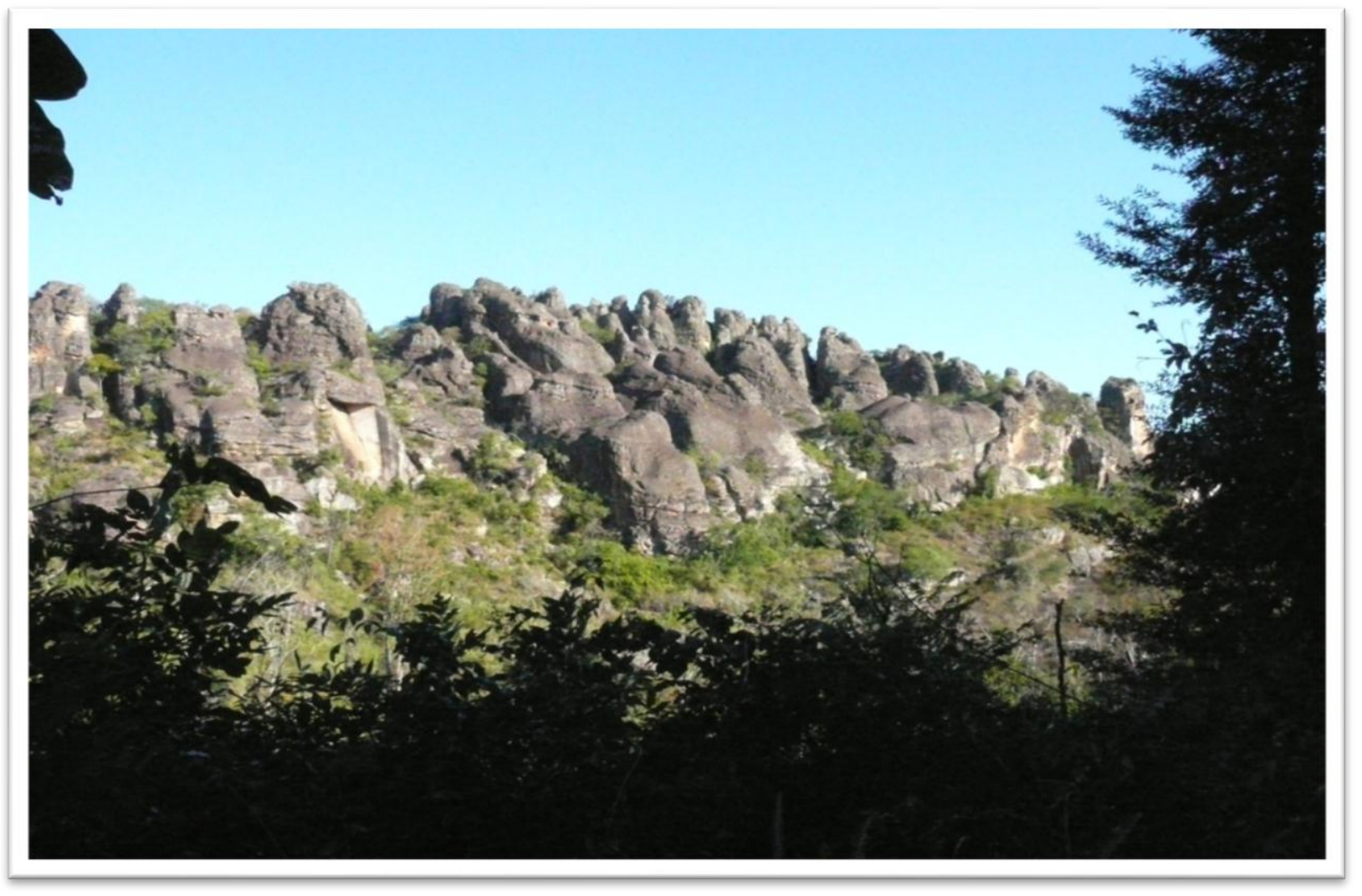

Figura 2- Erosão diferencial da Cidade de Pedra. Foto- I. Doneux, 2009.

Distinções em função da rugosidade topográfica ou índice de dissecação do relevo conforme o percurso que o rio Vermelho faz, produzem condições espaciais de compartimentação e formação de microambientes, que foram notados pelos pesquisadores e estabeleceram as divisões de estudo em função da segmentação estrutural da área. Nota-se, portanto, a congruência da ocupação humana na Cidade de Pedra no período Holocênico em relação a outras áreas do cerrado, que apresentam falésias e paredões de vertentes com processos erosivos e mata orográfica circundante.

Uma vez delimitadas as áreas planálticas que circundam a Cidade de Pedra, é necessário também considerar as áreas adjacentes localizadas na planície até a extensão das cercanias do Pantanal mato-grossense. O contato com esta região é proposta em função da existência de uma área fonte de extração de matéria-prima metassedimentar denominada 
rocha verde. Esta é encontrada em uma série de sítios da Cidade de Pedra, incluindo Abrigos Vermelhos.

Segundo Silva $(2005$, p. 34) a rocha verde não se trata de rocha sedimentar e há dificuldade em afirmar que se trate de uma rocha ígnea. Sua petrografia sugere metamorfismo, mas o protólito (minerais formadores de uma nova rocha) não foi encontrado (SILVA, 2005, p.34), de modo que na região de Rondonópolis há uma situação de metamorfismo que não é descrita na região da área e que a primeira vista passa por uma rocha ígnea que não existe na área (SILVA, 2005, p.46-47).

No médio e baixo curso do rio Vermelho predomina declividades entre 0 a $15 \%$, enquanto que, o relevo no seu curso superior é caracterizado por declividades entre 15 a $70 \%$ (WÜST, 1990, p. 21). No baixo trecho, o rio Vermelho e o córrego Arareau, que cortam o município de Rondonópolis, deságuam na bacia do rio São Lourenço, que, por sua vez, se direciona para o Pantanal mato-grossense. Este complexo compreende também o ribeirão Ponte de Pedra, localizado em área peri-pantaneira da bacia hidrográfica do rio Vermelho (NARDES, 2005, p.11).

O município de Rondonópolis tem importantes mananciais hídricos que podem ser explorados tanto pelas suas possibilidades de reserva de aquífero quanto pela alta densidade hidrográfica (NARDES, 2005, p.31), de modo que no período das cheias são avistadas formações como lagoas e braços abandonados nas margens do rio (WÜST, 1990, p.30).

Nota-se também uma rede hidrográfica menor, ramificada e intermitente de rios e riachos, que diminuem a vazão na época de seca, contrapondo-se ao amplo vale drenado pelo rio Vermelho (WÜST, 1990, p.19), quase desaparecendo, ou mesmo desaparecendo em determinadas épocas do ano, embora seja característica do cerrado a preservação intensiva dos padrões de perenidade dos cursos d'água regionais ao longo do ano (AB’SABER, 2003, p.38).

A planície do rio Vermelho comunica-se com a bacia do rio São Lourenço e, este, por sua vez, engloba a subdivisão de áreas não ou pouco inundáveis do Pantanal mato-grossense que mantém contato com Rondonópolis, representadas pelas baías que se situam entre as cidades de Santo Antônio do Leverger e Barão de Melgaço, com áreas alagáveis denominadas várzeas ou baixadas (SILVA \& SILVA, 1995, p.26).

$\mathrm{O}$ aspecto mais significativo desta configuração regional que atinge em certa medida, a Cidade de Pedra é o pulso das enchentes, fator a ser explorado e que se comunica diretamente com o fluxo das águas do rio Vermelho, cuja consolidação do regime da época das cheias produz mudanças significativas nas unidades paisagísticas da região do Pantanal 
(SILVA \& SILVA, 1995, p 28).

Mudanças significativas das unidades paisagísticas do Pantanal apresentam dependência do regime das chuvas e as rotas migratórias de peixes que influenciam a o alto nível de psicosidade do rio Vermelho e afluentes e a conspicuidade da área do ecótono da Cidade de Pedra, evidenciada pela presença de peixes de médio e grande porte da ordem dos Characiformes e da ordem dos Siluriformes ${ }^{1}$ (SANTANA-PORTO et. al., 2005, p.2) e o turgir de uma rede hidrográfica intermitente de rios e riachos que aumentam a vazão na época de chuva e adentram na Cidade de Pedra. Dentre estes, está presente o córrego da Sucuri que se localiza a poucos metros do sítio Abrigos Vermelhos.

As riquezas dos elementos naturais não deve ter passado desapercebidas aos habitantes dos abrigos rupestres e das áreas de vertentes, dada que a composição arbustiva do cerrado, além das diferenças de composição arbórea que possui a beleza dos períodos de florada, tornam-se também recursos aproveitáveis conforme seus frutos, cascas e óleos, não somente devido ao seu grande teor nutritivo, mas em função de propriedades medicinais, artesanais e estéticas.

Por outro lado, elementos de um ambiente ribeirinho regulado pelos períodos de seca e de cheias, produzindo lagoas, braços abandonados e estrangulamentos, nos informam sobre os reservatórios de peixes, sobre as prováveis épocas de fartura e as estratégias de cultivo das áreas de planície, proporcionando a imagem da conspicuidade visual da área do ecótono. A conspicuidade visual da área de ecótono refere-se à clara visibilidade estética e correlação da disponibilidade em abundância dos recursos materiais.

Esta composição específica da Cidade de Pedra formada pela área de ecótono cerrado - floresta formam microclimas que se relacionam com as condições de solo e topografia (RATTER, 1992, 41), de modo que produzem respostas diferenciadas de ocupação, revelando diferenças entre suportes naturais distintos. No caso da Cidade de Pedra estes mecanismos naturais parecem se comportar mais como uma zona de atratividade do que como uma zona de contenção ou corredor de passagem entre um bioma e outro.

\footnotetext{
${ }^{1}$ Representantes da ordem Characiformes nos rios Vermelho e São Lourenço: Piraputanga (Brycon hilarii); Dourado (Salminus maxillosus); Curimbatá (Prochilodus lineatus); Pacupeva (Metynnis maculatus); Piranha (Pygocentrus nattereri); Cachorra (Hydrolycus scomberoides); Pacu (Piaractus mesopotamicus); e da ordem Siluriforme- Jaú (Paulicea luetkni); Barbado (Pinirampus pirinampus); Palmito (Ageneiosus brevifilis); Bico de Pato (Schizodon isognathus); Mandi amarelo (Pimelodus maculatus); Cachara (Pseudoplatystoma fasciatum ); Jurupoca (Hemisorubim platyrrhynchus); Cascudo (Hypostomus plecostomus), (SANTANAPORTO et al, 2005, p.2).
} 
Estes dados são corroborados pela possibilidade de acesso facilitado em determinadas épocas do ano, pela conspicuidade do cerrado e pela amenidade do clima que favorece a atração de fauna e de pessoas a partir de áreas mais quentes ou muito mais úmidas. A cultura material também aponta para evidencias de que as relações humanas foram mantidas com áreas fora do perímetro das formações rochosas areníticas do núcleo central da Cidade de Pedra, notadamente com o Pantanal mato-grossense, como consta a partir da presença de rocha metassedimentar oriunda de regiões peripantaneiras, além dos elementos presentes nos antiplásticos de fibras vegetais contidas na cerâmica de Abrigos Vermelhos, e possivelmente coletados nesta região. 


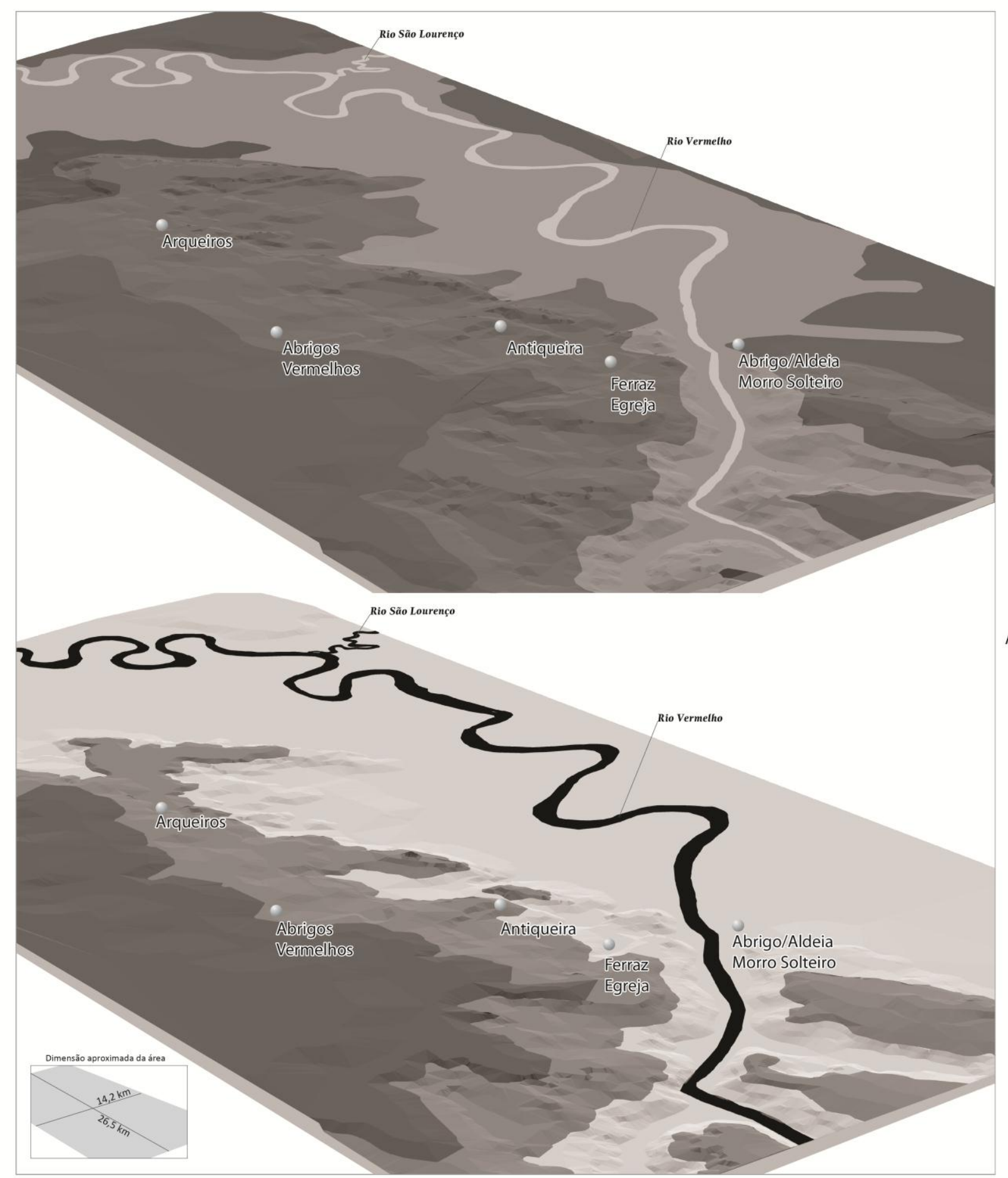

MODELAGEM DE RELEVO - ABRIGOS VERMELHOS

Topografia, Fitounidades e fitogrupos regionais

DOMÍNIO DO CERRADO Fitounidades e fitogrupos paisagísticos LEGENDA

\section{$\sum$ Hidrografia}

Fitounidades e Fitogrupos Domínio Morfoclimático dos Cerrados

Antropismo - Pecuária [pastagens] e savana (campos abertos)

Contato Savana / Floresta Estacional - encrave/Savana Florestada+Floresta Estacional Decidual Submontana Dossel emergente

Floresta Estacional Semidecidual Aluvial Dossel emergente+Formação Pioneiras com influência fluvial e / ou lacustre - herbacea sem palmeiras

Fonte: SIVAM, PROBIO MMA.

PERFIL TOPOGRÁFICO - ABRIGOS VERMELHOS

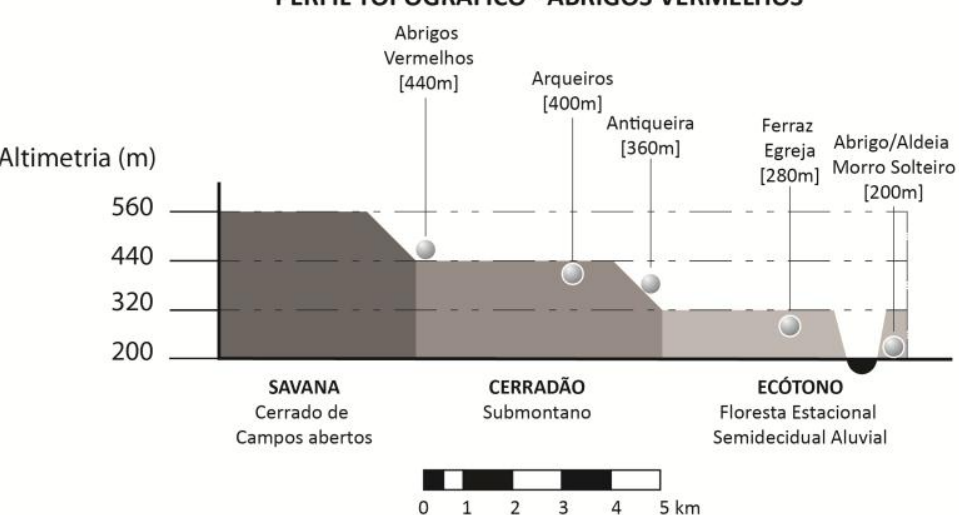

TOPOGRAFIA REGIONAL DA PAISAGEM

LEGENDA

$\Sigma$ Hidrografia

Altimetria $(\mathrm{m})$

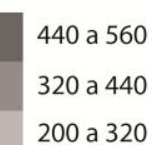

Fonte: INPE, EMBRAPA 


\subsection{A CIDADE DE PEDRA E AS RELAÇÕES COM AS FORMAÇÕES AMBIENTAIS INTERNAS}

Os dados que nos ajudam a compreender a condição de contato e integração de Abrigos Vermelhos em relação aos demais sítios da Cidade de Pedra são aqueles realizados até o momento com foco na antracologia (BACHELET, 2011) e nas fontes de captação de recursos litológicos (SILVA, 2005). Estes dados reúnem condições para pensarmos em Abrigos Vermelhos como um local que guarda semelhanças não somente com seu entorno, mas também apresenta certas peculiaridades relativas à inserção geográfica e a caracterização de condições especiais de localização e das condições da vegetação circundante.

Do ponto de vista da vegetação, a Cidade de Pedra abarca uma zona de mata ripária, o cerrado stricto sensu, mata seca, veredas, campo sujo, campo limpo e cerradão (BACHELET, 2011, p.24-29). A vegetação ribeirinha pode ser definida especificamente como o ecótono stricto sensu, zona ripária, mata ciliar ou ainda florestas de galerias que contêm vegetação, solo e rio (KOBIYAMA, 2003, p.1). É reconhecida como corredor para movimento de animais dentro do sistema de drenagem (Gregory et al., 1991, apud, KOBIYAMA, 2003, p.2) e sua extensão tem potencial para área de manejo até o topo da copa da floresta (KOBIYAMA, 2003, p.4). Na região da Cidade de Pedra, a zona ripária apresenta uma área consideravelmente menor que o platô, mas é cultivável e onde se avistam sítios ceramistas localizados nas margens de planície do rio Vermelho (FIGUTI, 2006, p.211).

A savana de bosques é conhecida como cerrado stricto sensu e pode ser definida como um conjunto de arvoretas que lhes servem de suportes ecológicos (AB’SABER, 2003, p.36). O cerradão, por sua vez, é composto por florestas xeromórficas em terras altas (RATTER, 1992, p.172), apresentando floresta quase fechada, com copa cobrindo a área em 50\% a 90\% de árvores, muitas vezes com aporte de 8 a 12 metros ou mais alto (OLIVEIRA-FILHO \& RATTER, 2002, p.96). 


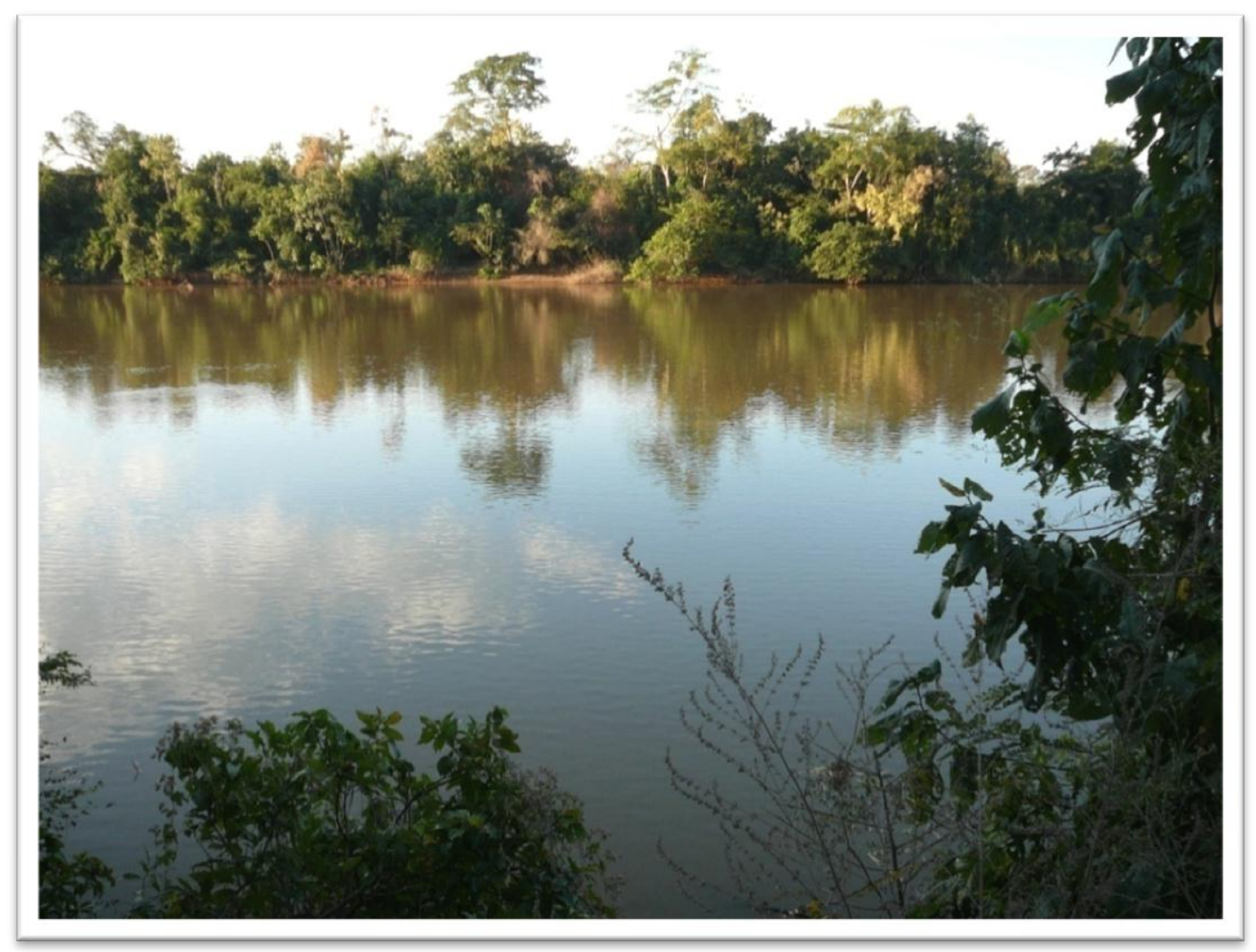

Figura 4 - Rio Vermelho e a zona ripária da Cidade de Pedra. Foto: I. Doneux, 2009.

Do ponto de vista da ocupação humana os estudos dos vestígios antracológicos, realizados em alguns abrigos rupestres da Cidade de Pedra, indicam o uso de recursos vegetais vinculados à área de ecótono e à floresta decídua ou semidecídua. Porém, quando os táxons, presentes nos abrigos rupestres Ferraz Egreja, Antiqueira e Pacífico e no sítio Aldeia Morro Solteiro, são analisados comparativamente, percebem-se maiores semelhanças entre táxons presentes no abrigo rupestre Ferraz Egreja e Antiqueira com 14 táxons em comum, seguido por Ferraz Egreja e Morro Solteiro com 10 táxons em comum, enquanto Pacífico, Antiqueira e Morro Solteiro apresentam quatro ou cinco táxons em comum (BACHELET, 2011, p.216).

Ferraz Egreja, Antiqueira e Morro Solteiro são sítios relativamente próximos entre si e compartilham a característica de estarem completamente inseridos dentro da área do ecótono, enquanto que o abrigo Pacífico, está fora desta área e ao seu lado está o abrigo rupestre Arqueiros, [figura 3], localizados fora da área central da Cidade de Pedra, concentrados em uma área de florestas e encrave de savana florestada e floresta estacional decidual submontana dossel emergente. 
Estes resultados apontam para certa compartimentação de zonas de circulação humana dentro da Cidade de Pedra, cujos recursos madeireiros são extraídos do seu entorno imediato. Além disso, esta região tem como característica o contato com sítios mais próximos entre si e com uma área entre a planície e o ecótono com cotas altimétricas estabelecidas em até 320 metros, [figura 3], sendo rara a comunicação com as áreas mais altas da vegetação típica de cerradão, porção esta que inclui Abrigos Vermelhos [figura 3].

Esta análise alinha-se com os resultados dos estudos realizados sobre a distância das fontes de captação dos recursos litológicos da área da Cidade de Pedra, cujos afloramentos rochosos, dos quais foram extraídos matéria-prima, são geralmente próximos aos sítios arqueológicos, não extrapolando um raio de 5 km de distância (AUBRY, 2006, p.24).

A caracterização geológica e das áreas fontes de extração de material litológico da área da Cidade de Pedra é fundamental para considerarmos a zona de circulação e relações de Abrigos Vermelhos com seu entorno, a influência da qualidade da matéria-prima no lascamento executado e a relação com os afloramentos litológicos, dos quais se extraíram estes recursos.

A Formação Furnas é constituída por arenitos grossos a muito grossos (LACERDA FILHO et. al., 2004, p.105). Desde as cercanias da Chapada dos Guimarães até o limite sul do estado do MT, esta formação geológica aflora em camadas de arenitos médios a grossos, com estratificação cruzada, arenito fino com laminação cruzada, e arenitos finos com estratigrafia cruzada (LACERDA FILHO et. al., 2004, p.105).

Estes recursos litológicos foram amplamente utilizados dentro dos abrigos rupestres, constituindo a maior parcela de material depositado (SILVA, 2005, p.51). Não obstante, sua presença restringe-se a um perímetro de captação muito próximo ou dentro da área central da Cidade de Pedra, cujos afloramentos estão localizados em cotas altimétricas preferencialmente de até $300 \mathrm{~m}$, [figura 3]. A aptidão deste material ao lascamento é variável, chegando ao sítio Abrigos Vermelhos previamente trabalhados pelo processo de descorticamento, apresentando, desse modo, as primeiras etapas de redução realizadas fora do sítio.

Além da Formação Furnas, deve-se considerar a Formação Ponta Grossa. Nas regiões centro sul e leste do estado do MT, esta formação se sobrepõe à primeira por contato gradual e concordante (LACERDA FILHO et. al., 2004, p.106). Encontra-se mais alta e fora do perímetro da Cidade de Pedra, caracterizada pelo aumento relativo dos sedimentos siltosos e arenosos muito finos e resistentes à erosão em cotas a partir de 400 metros (AUBRY, 2006, p.23). Embora fosse possível sua extração em áreas localizadas na margem direita do rio 
Vermelho, é pertinente questionar por que este arenito, de composição mais fina e mais apropriada à confecção de artefatos não foi sistematicamente aproveitado em Abrigos Vermelhos.

A parcela de arenito silicificado de fina granulometria e o sílex são recolhidos e indicam deslocamento fluvial pelo leito do rio Vermelho, sendo possível a captação na calha. Entretanto, nos dias atuais, não se verifica a existência de cascalheiras a pelo menos a $15 \mathrm{~km}$, tanto a jusante quanto a montante do rio (SILVA, 2005, p.38-45), indiciando que podem estar associados a regiões a montante (Planalto dos Alcantilados), nas quais este tipo de material é característico (SILVA, 2005, p.45). Este material que apresenta processos de silicificação consolidados e aptos ao trabalho do talhe chegou aos Abrigos Vermelhos de modos diferenciados, em forma de pequenos seixos não abertos, parcialmente abertos, ou completamente descorticados.

Nota-se também a presença do grupo litológico Cuiabá, composto por rochas metassedimentares afetadas por metamorfismo regional em fáceis xistos verdes e em contato com os arenitos da Formação Furnas (SILVA, 2013, p.47). Este tipo de material está associado à área de planície, a cerca de $19 \mathrm{~km}$ de distância da Cidade de Pedra, seguindo a jusante no rio São Lourenço, nas cercanias do Pantanal mato-grossense (SILVA, 2005, p.47). Suas qualidades de fina granulometria são aptas ao trabalho do polimento. Em Abrigos Vermelhos esta matéria prima chegou descorticada em pequenos blocos ou na forma de seixos.

Entre os minerais, encontra-se o óxido de ferro, constituído por seixos e plaquetas de silte com forte teor de óxido de ferro em posição secundária na Formação Cachoeirinha, (N1d1) (Zona basal com rochas subjacentes alteradas, areias, argilas e níveis conglomeráticos, parcialmente lateralizadas; uma zona média concrecionada de lateritos ferruginosos compactos), [figura 5]. São encontrados em diversos pontos da Cidade de Pedra, associados a drenagens secundárias (SILVA, 2005, p.64), e, em Abrigos Vermelhos, estão associados a princípio, ao instrumental de produção de arte rupestre. 


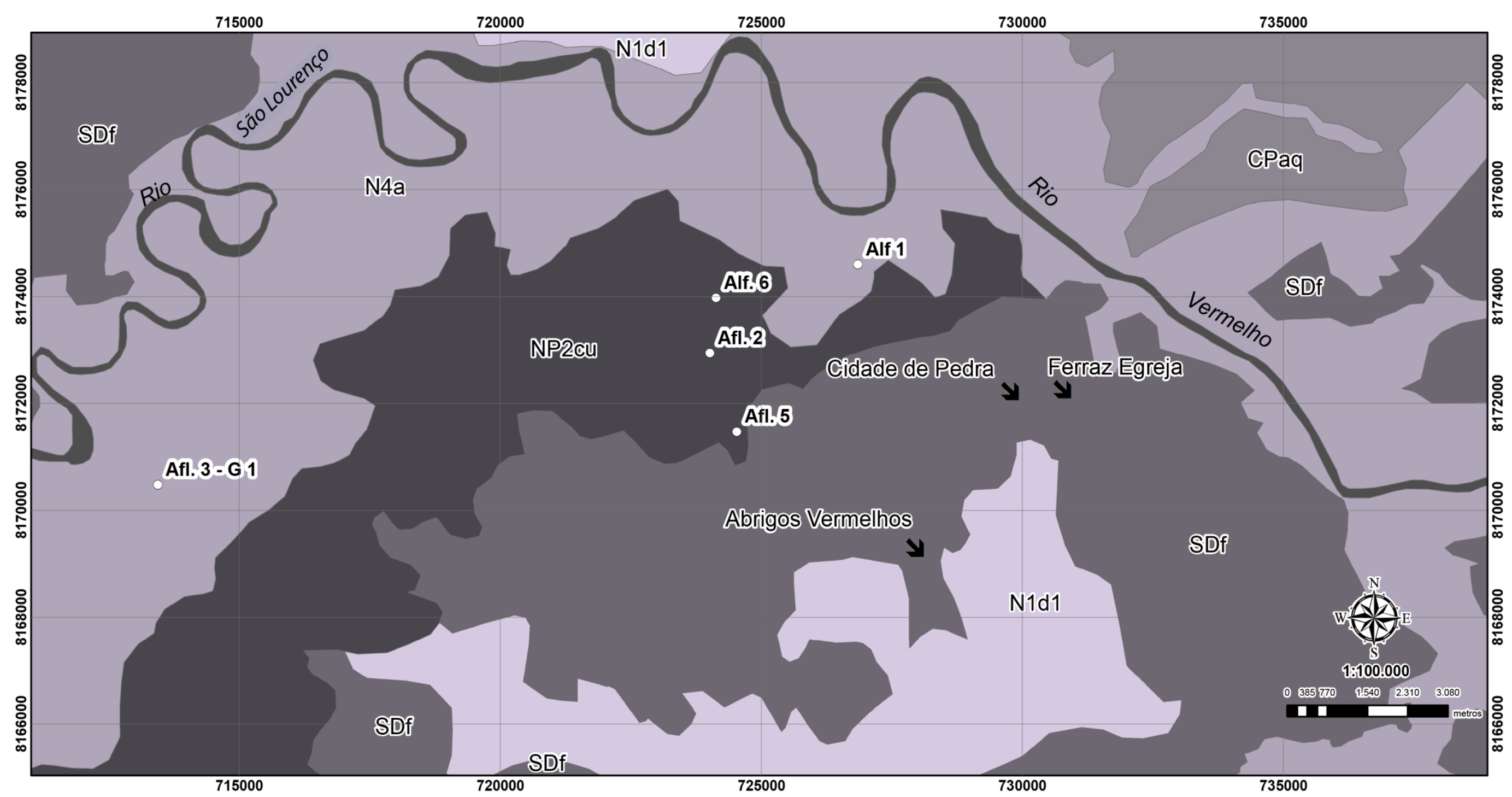

\section{Fontes de Captação de Recursos Litológicos}

\section{Legenda}

Possiveis afloramentos litológicos que configuram as rochas presentes $\mathrm{e}$ aproveitadas nos sítios arqueológicos
da Cidade de Pedra Fonte: Silva, 2005

un Corpos d'água

Y Sítios Arqueológicos

\begin{abstract}
Geologia Estrutural
SIGLA Descrição

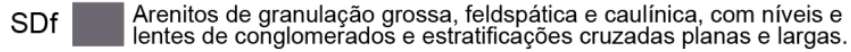

N4a Depósitos conglomeráticos, arenosos e pelíticos.

Metaconglomerados polimíticos, meta-arenitos, meta-arcósios,
metassititos, filitos, microconglomerados, metaconglomerados e

metacalcários.
\end{abstract}

SIGLA Descrição

Edição de Carlos A. Rizzi Janeiro de 2013

CPaq Sequência sedimentar arenosa com três niveis; superior (arenitos com (arenito cóm lentes de diamictitos).

Fontes

N1d1 Zona basal com rochas subjacentes alteradas, arelas, argilas e niveis conglomeraticos, parcialmente laterizadas; uma zona media concrecionária
de lateritos ferruginosos compactos i uma zona superior com solos argilosos. Earth Science Data Interface SAD 1969 UTM Zona 22S Projeção: Transversa de Mercator Meridiano Central: $-45,0000$

GCS South American 1969 
Os dados de análise provenientes do estudo das fontes de captação dos recursos litológicos apontam sobre diferenças em torno da ocupação do espaço da Cidade de Pedra, relacionados ao tipo e tratamento das matérias-primas líticas e respostas diferenciadas quanto à apropriação da geoestrutura presente.

Para as matérias-primas líticas mais aptas ao lascamento, de possível ou comprovada origem alóctone, a interação com o espaço volta-se para o rio Vermelho, tanto na captação dos seixos de arenitos bem silicificados, potencialmente transportados de áreas à montante, quanto no contato com lugares onde há rochas metassedimentares associadas às áreas pantaneiras circundantes, localizadas à jusante.

Concernente às matérias-primas menos aptas ao lascamento, compostas pelo arenito silicificado de grosseira granulometria e pelo óxido de ferro, nota-se a extração dos afloramentos areníticos localizados na área central da Cidade de Pedra, utilizando a geoestrutura circundante como matéria-prima, se voltando para os paredões do perímetro central da área, em cotas altimétricas em até 300 m [Figura 3].

Assim, dentro do perímetro central da Cidade de Pedra é previsível encontrar uma geoestrutura ao longo do tempo e de longa duração com qualidades de aproveitamento reconhecíveis destas matérias-primas. Isto pode demonstrar que a qualidade do arenito silicificado pode ser selecionada em alguns casos, mas não deve ser fator decisivo de interferência na performance do lascamento, haja visto a recorrência de extração nos mesmos pontos e da longa utilização destes recursos menos aptos ao lascamento, nunca abandonados em Abrigos Vermelhos.

A partir da relação de espacialidade estabelecida para as matérias-primas dentro do perímetro da Cidade de Pedra e dos comportamentos diferenciados em relação ao tipo, extração e técnicas iniciais de desbastamento aplicadas a elas, é pertinente perguntar sobre as evidências de temporalidade e espacialidade destas matérias primas dentro do sítio arqueológico. A presença, o tipo e a forma de apropriação destes recursos líticos dentro da Cidade de Pedra apresentam diferenças quanto às áreas de captação, de modo que a questão a ser encaminhada é se estas matérias-primas são aproveitadas de forma diferenciada e/ou apresentam sequências estratigráficas delimitadas, relacionando-se com horizontes cronológicos específicos e composições espaciais a partir de áreas distintas. 


\subsection{ABRIGOS VERMELHOS E O CONTEXTO DA CIDADE DE PEDRA}

Na última seção deste capítulo o microambiente específico do sítio será visto em consideração a seu entorno e outros microambientes que integram esta paisagem. Localizado a 440 metros de altitude, em área de cerradão, situa-se na parte central de um aplainado patamar entre o topo da chapada e a escarpa da serra (DeBLASIS, 2006, p.145), abrindo-se para um anfiteatro, onde é possível alcançá-lo a partir dos chapadões do cerrado para quem desce para os patamares areníticos da área central da Cidade de Pedra em direção à planície, ou para quem sobe em direção aos patamares areníticos, seguindo para o planalto, [figura 6].

Está imerso em meio a uma série de formações areníticas que sofre processo de desnudação causado por fatores climáticos que são encontrados por toda a composição arenítica da área central da Cidade de Pedra, aprofundando gradativamente em direção sudoeste. Esta erosão diferencial domina todo o entorno imediato deste sítio dentre os afloramentos residuais escarpados da Formação Furnas, configurando formas topográficas de altimetrias diferenciadas e contornos e delineações dos mais diversos tipos.

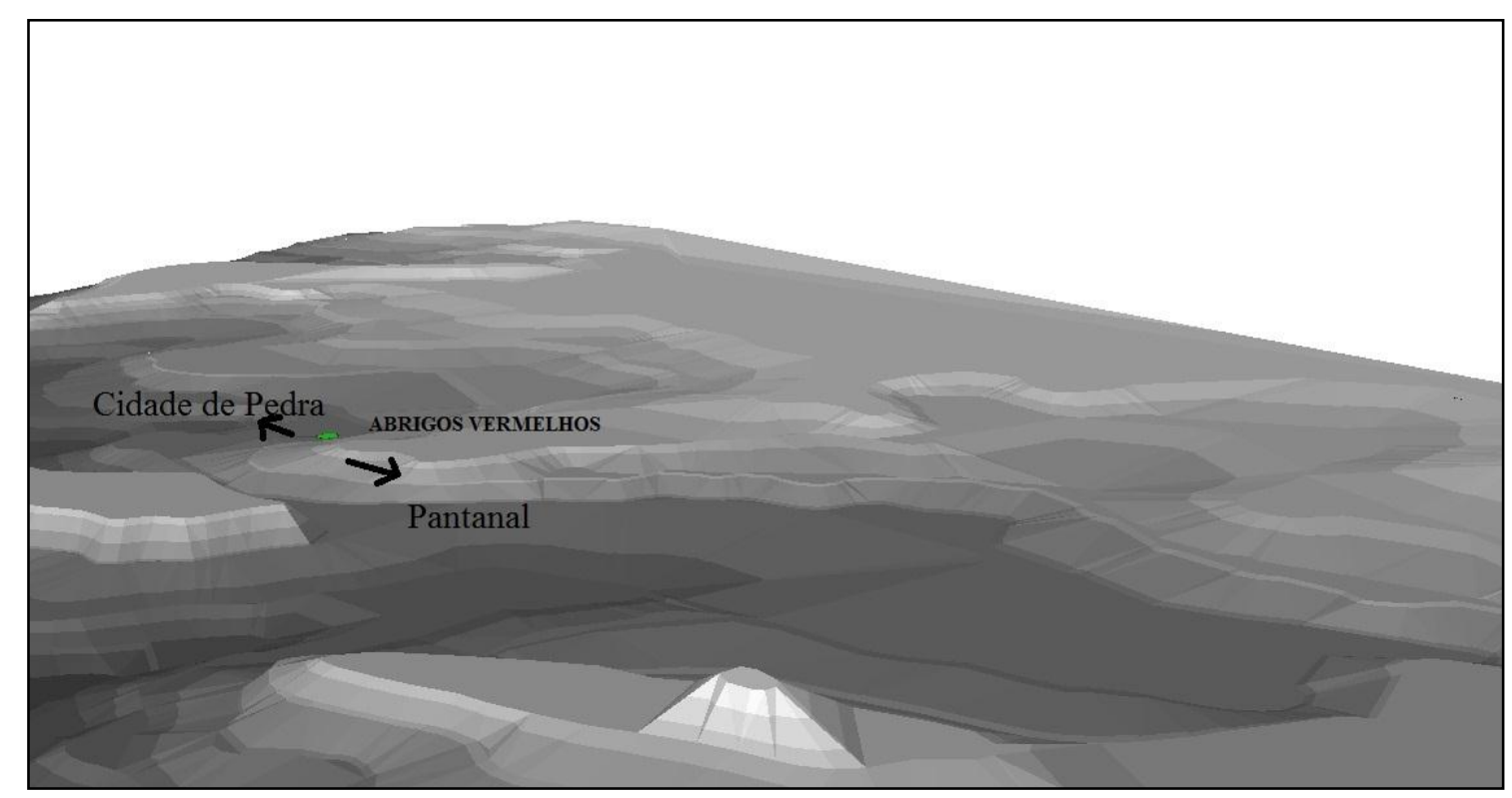

Figura 6 - Posição topográfica de Abrigos Vermelhos. Modelagem de Relevo. 
A microbacia dos Abrigos Vermelhos é relativamente plana e pouco drenada, sem contenções de paredões laterais notáveis, possibilitando alcançar outras microbacias da Cidade de Pedra, incluindo a microbacia de Ferraz Egreja, através das planícies aluviais que a cercam (VIALOU, 1993, p.493), sendo possível acesso e circulação por meio da microbacia da Sucuri, localizada a poucos metros de Abrigos Vermelhos.

A localização geográfica de Abrigos Vermelhos poderia sugerir isolamento devido as suas características topográficas. Não obstante, a topografia do sítio é considerada um fator que imprime à paisagem uma marca de entroncamento de rotas e caminhos entre três áreas distintas, tal qual a presença de diferentes matérias-primas depositadas em seu interior e seus pontos de extração, revelam.

Este alto sítio localizado na parte mais ao sul da área comunica-se com os patamares elevados de formações geológicas superiores à Cidade de Pedra, com a zona central arenítica ruiniforme e com a área ribeirinha de ecótono. Também permite acesso à região oeste da Cidade de Pedra, que vai de encontro às de cercanias do Pantanal mato-grossense, constituindo um encrave na zona de circulação entre vertentes e planícies [figura 7]. Estes dados espaciais reúnem condições para pensarmos em um lugar privilegiado do ponto de vista de marcações de limites físicos e de rotas, entroncamentos e caminhos.

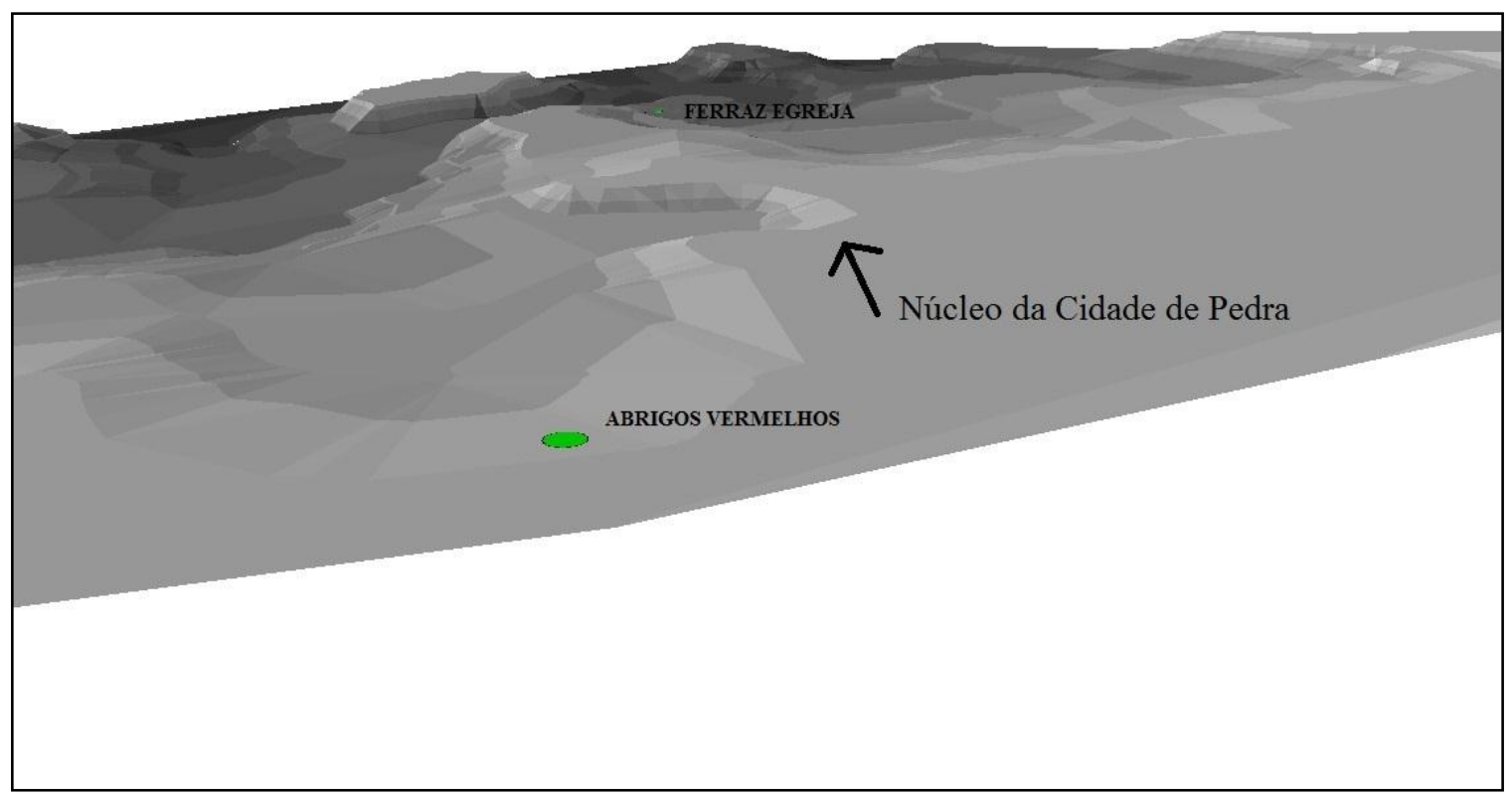

Figura 7 - A microbacia de Abrigos Vermelhos. Modelagem de Relevo. 


\subsection{SÍNTESE DO CAPÍTULO}

A Cidade de Pedra é um complexo formado por vertente cercada de mata orográfica, com acentuado processo de desnudamento erosivo que esculpe formas diversas no arenito de silicificação variável. Embora seja condizente com uma série de formações rochosas que cercam a Bacia do Alto Paraguai (BAP) é uma formação geológica peculiar na região do vale do rio São Lourenço, tornando-se uma região de encrave entre formações geológicas e biomas distintos. Não pertence a uma categoria de espaço isolado em relação ao seu entorno, cujos pontos de extração das matérias primas líticas revelam conexões de caminhos e redes de contato dentro e fora da Cidade de Pedra.

Relações significativas quanto à zona de captação das matérias primas líticas, concernentes ao sílex, ao arenito silicificado fino e ao óxido de ferro são recolhidos na forma de seixos em pontos e estratégias diferenciadas ao longo da drenagem do rio Vermelho, revelando diferenças técnicas executadas nos suportes que demandam conhecimento específico, cujas características físicas indicam proveniência de regiões a montante. Este mesmo raciocínio se aplica aos maciços de arenito da área central em que matérias primas de arenito silicificado grosso demandam conhecimento específico e podem ser revisitados dentro da área central da Cidade de Pedra. A exceção parece se relacionar à parcela de rocha verde que extraída do perímetro externo à Cidade de Pedra é um tipo de material buscado ou introduzido, modificando a relação humana em relação às zonas de coleta das matérias primas líticas.

A síntese produzida a partir dos dados disponíveis é que a partir de pontos diferentes da Cidade de Pedra e de zonas adjacentes, há qualidades, suportes e pontos de coletas distintos, cujo perímetro de rotas e caminhos percorridos até os Abrigos Vermelhos é extenso e envolve nichos topográficos distintos e quiçá temporalidades distintas. 


\section{Capítulo III}

E isso é o pensamento matemático: é uma certa forma de querer organizar o mundo

(CUNHA, 2009, p.15)

\section{A TEMPORALIDADE E A ESPACIALIDADE DE ABRIGOS VERMELHOS}

Considera-se que antes de avaliar qualquer relação com o mundo social é necessário explorar as potencialidades que um depósito arqueológico apresenta quanto aos processos formativos atuantes. Este o tema central deste capítulo que apresenta a análise da distribuição vertical e espacial das matérias-primas líticas e da cerâmica na área escavada do sítio.

O sítio Abrigos Vermelhos comporta uma longa história de ocupação e episódios de uso que proveem dados para o estudo da sucessão do depósito sedimentar e da distribuição da cultura material em estratigrafia e áreas de escavação. A partir destas informações são possíveis estabelecer a cronologia de ocupações, além de dispor de elementos para gerar sínteses de ocupações de áreas de atividades, reunindo elementos da cultura material e da distribuição espacial destes elementos.

A partir destas informações e das características de uso ininterrupto do espaço e da cronologia estabelecida para o depósito arqueológico de Abrigos Vermelhos, permite-se tratar uma das questões elencadas na introdução desta pesquisa, referente à detecção da transição de um horizonte caçador-coletor tardio para um horizonte ceramista, ou de evidências de continuidade e ininterrupção ao longo do tempo de produção artefatual lítica que não pode ser distinta. Esta é uma questão central que abre perspectivas para o exame do comportamento humano estabelecido neste lugar, anterior ao horizonte cronológico dos sítios ceramistas instalados nas várzeas do rio Vermelho, mas que perpassa este período claramente.

Atualmente, muitas técnicas e procedimentos no âmbito de processos de formação de um sítio são emprestados e utilizados a partir das ciências naturais (VILLA, 1983, p. 271, STEIN, 1993, p.1). Estas informações lançam as bases para a avaliação dos padrões sobre a construção de uma cronologia cultural para o abrigo e para a distribuição da cultura material na área do sítio. Utilizando -se de concepção de Michael Schiffer (2010), tenta-se, neste capítulo discriminar processos culturais e não culturais, transformados espacialmente, quantitativamente, formalmente e relacionalmente (SCHIFFER, 2010, p.20). 
Segundo este autor o registro arqueológico comporta dimensões distintas que são expressas da seguinte forma:

\footnotetext{
Dimensão Formal: Artefatos frequentemente considerados tecno-funcionais [...] necessitam de inferências sobre seu modo de uso. Dimensão espacial: O termo área de atividade é aplicados a qualquer concentração de artefatos em área de descarte, limpeza ou pisoteamento [...]. Dimensão de Frequência: Absoluta e relativa frequência no contexto arqueologia pode não ter um significado comportamental, mas ainda são tratados como se tivessem [...]. Dimensão Relacional: Itens encontrados juntos, como uma estrutura em um solo de ocupação e por vezes considerados toolkits [...] (SCHIFFER, 2010, p.20, tradução nossa).
}

Isto posto, avaliaremos a estrutura física do abrigo delimitando os aspectos naturais da estrutura espaço, a descrição da sedimentologia e a e cronologia das estruturas de combustão em torno do espaço do sítio para realizar as análises de distribuição vertical e espacial da cultura material. Em seguida, delineia-se o método de escavação para termos medida do alcance da análise estabelecida sobre o sítio, e, por fim, são consideradas informações advindas dos artefatos e das estruturas a partir da plotagem e distribuição da cultura material, considerando as coordenadas cartesianas $\mathrm{x}$, y e a dimensão de profundidade (z).

\subsection{A ESTRUTURA FÍSICA DE ABRIGOS VERMELHOS}

O conjunto dos Abrigos Vermelhos constitui-se de um grande e multifacetado afloramento arenítico (DeBLASIS, 2006, p.145) que corresponde a quatro afloramentos rochosos de cerca de 10 metros de altura e de 4 a 8 metros de diâmetro do solo, com presença de erosão diferencial. O primeiro afloramento (C1) está situado a 15 metros ao sul dos outros três afloramentos $(\mathrm{C} 2, \mathrm{C} 3, \mathrm{C} 4)$, contendo os dispositivos rupestres mais importantes, [figura 8], (PAILLET, 2006, p.91). Ao sudeste, o conjunto II abriga sete painéis decorados com gravuras, desenhos e pinturas. A menos de 2 metros, na direção noroeste, o conjunto III apresenta três painéis que estão em contato direto com o conjunto IV e reúne oito painéis decorados com gravuras, desenhos e pinturas (PAILLET, 1996, p.94). No total, somam-se 18 painéis dispostos a 4 metros de altura do solo atual e distribuídos em quase toda a periferia dos quatro morros (PAILLET, 1996, p.95). Todos os relevés desenhados por Patrick Paillet (2006, p.100-123), podem ser visualizados a partir da próxima página. 


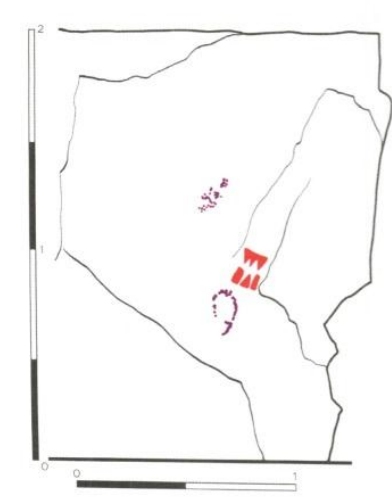

CONJUNTO I - Painéis 1, 2

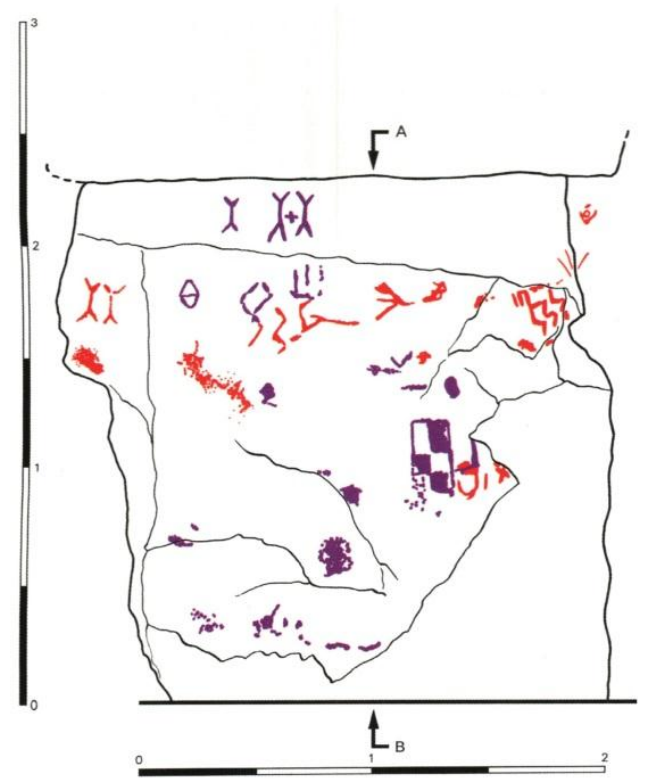

CONJUNTO I- Painel 4
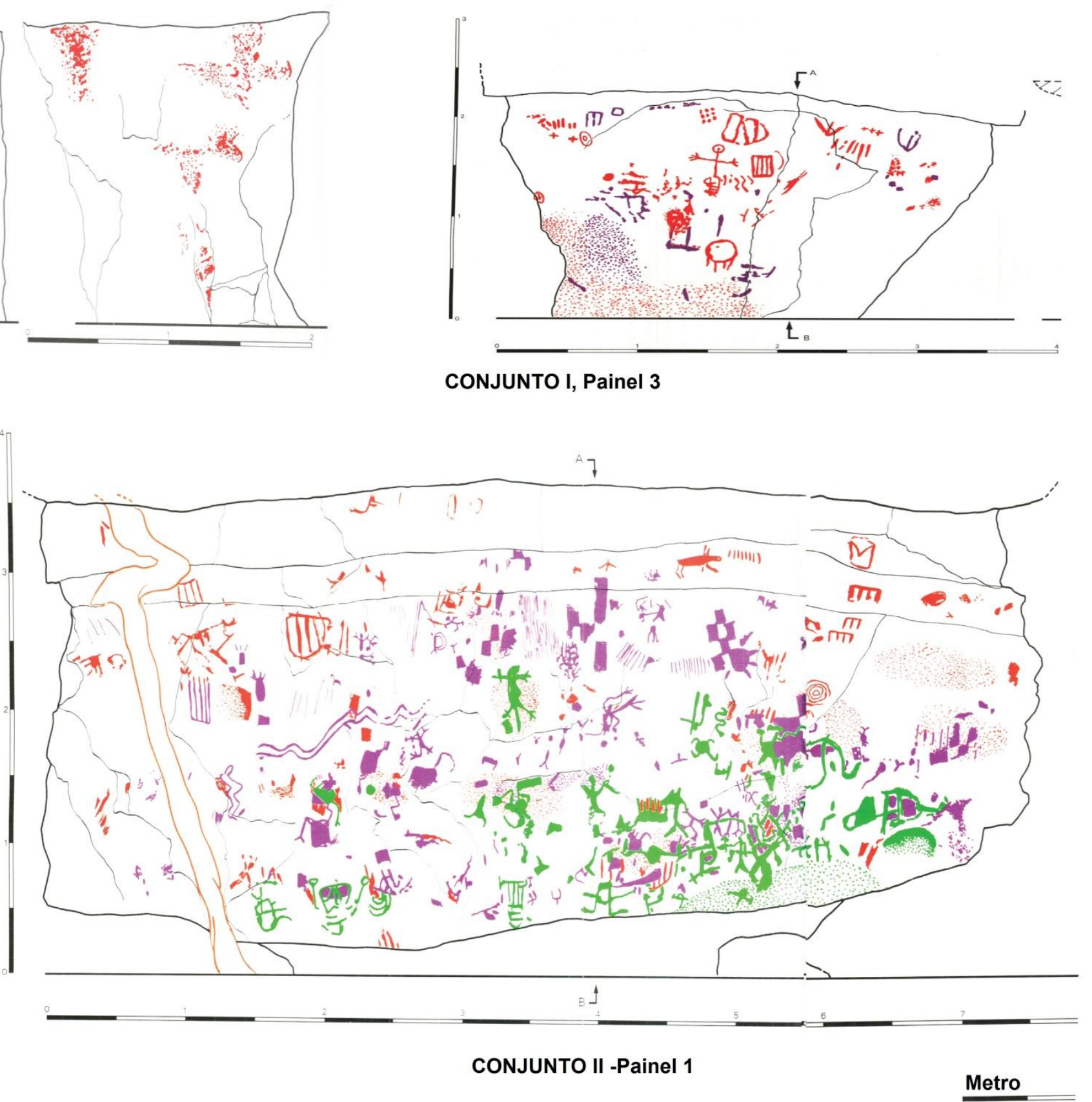
38

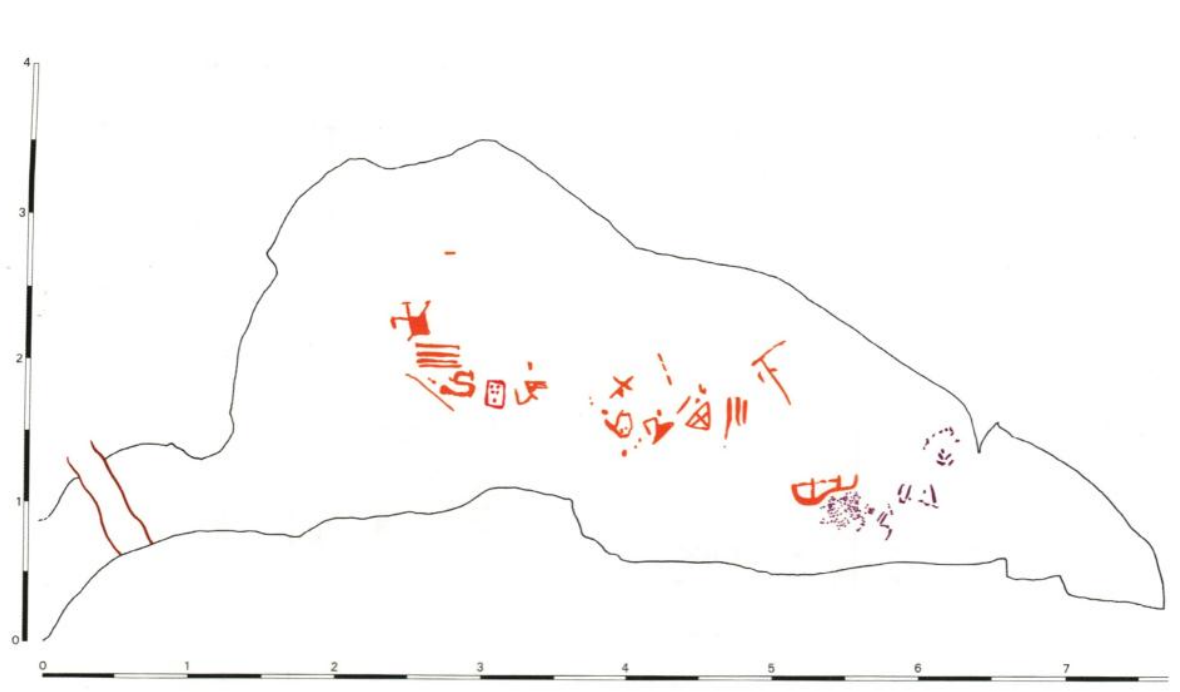

CONJUNTO II, Pianel 2

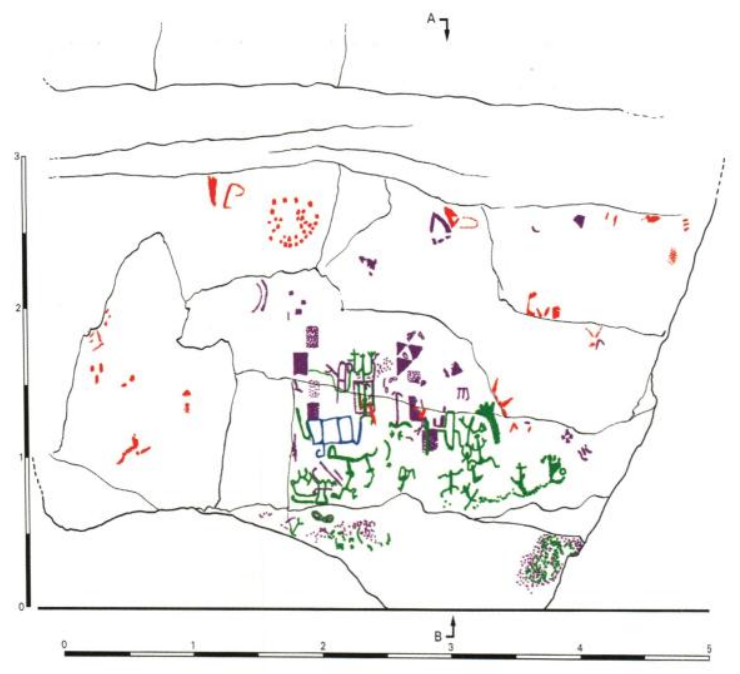

CONJUNTO II, Painel 4

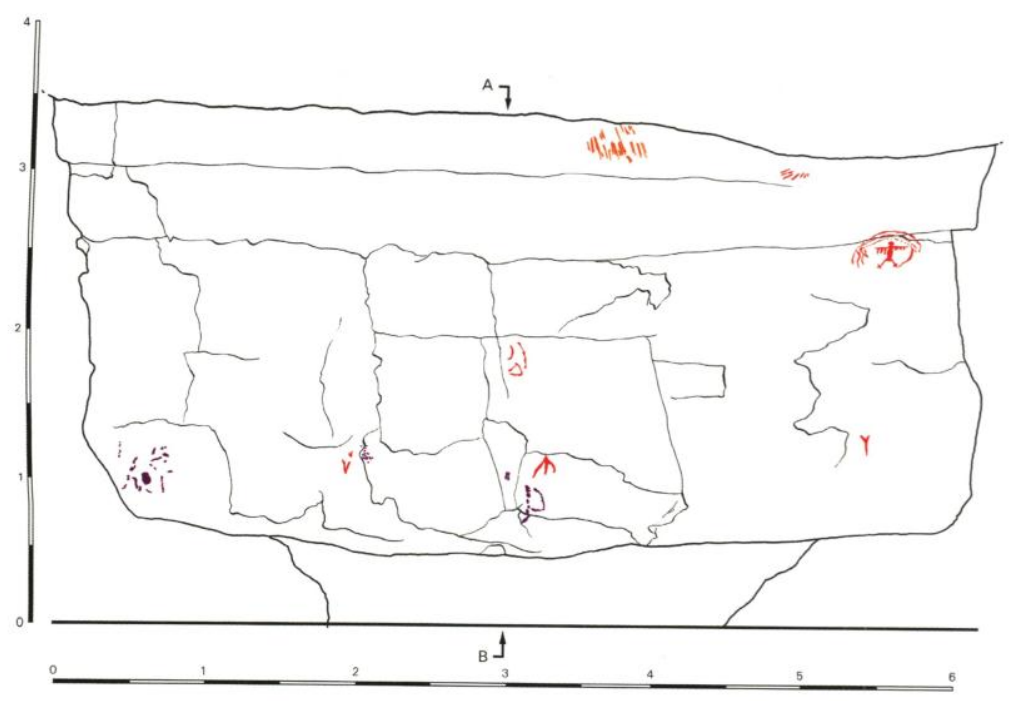

CONJUNTO II, Painel 3

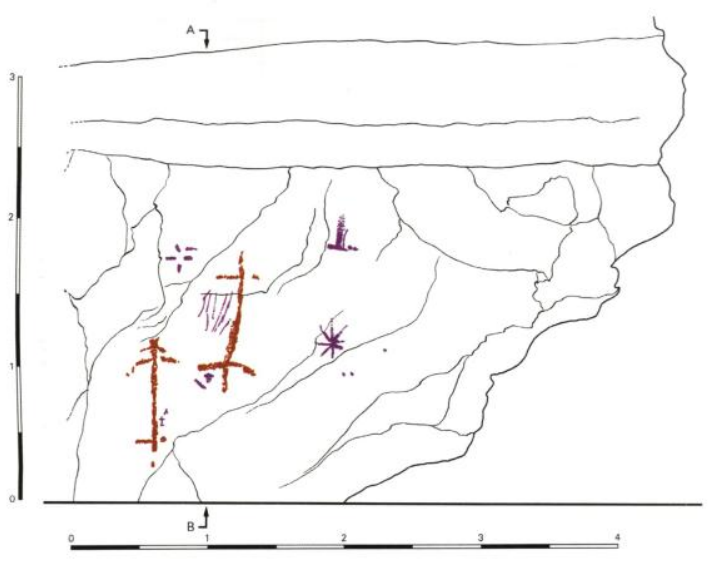

CONJUNTO II, Painel 5

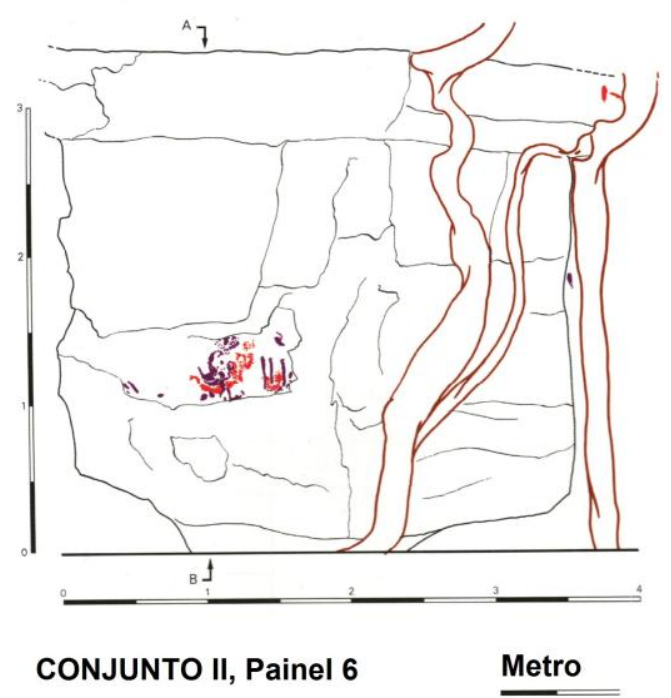



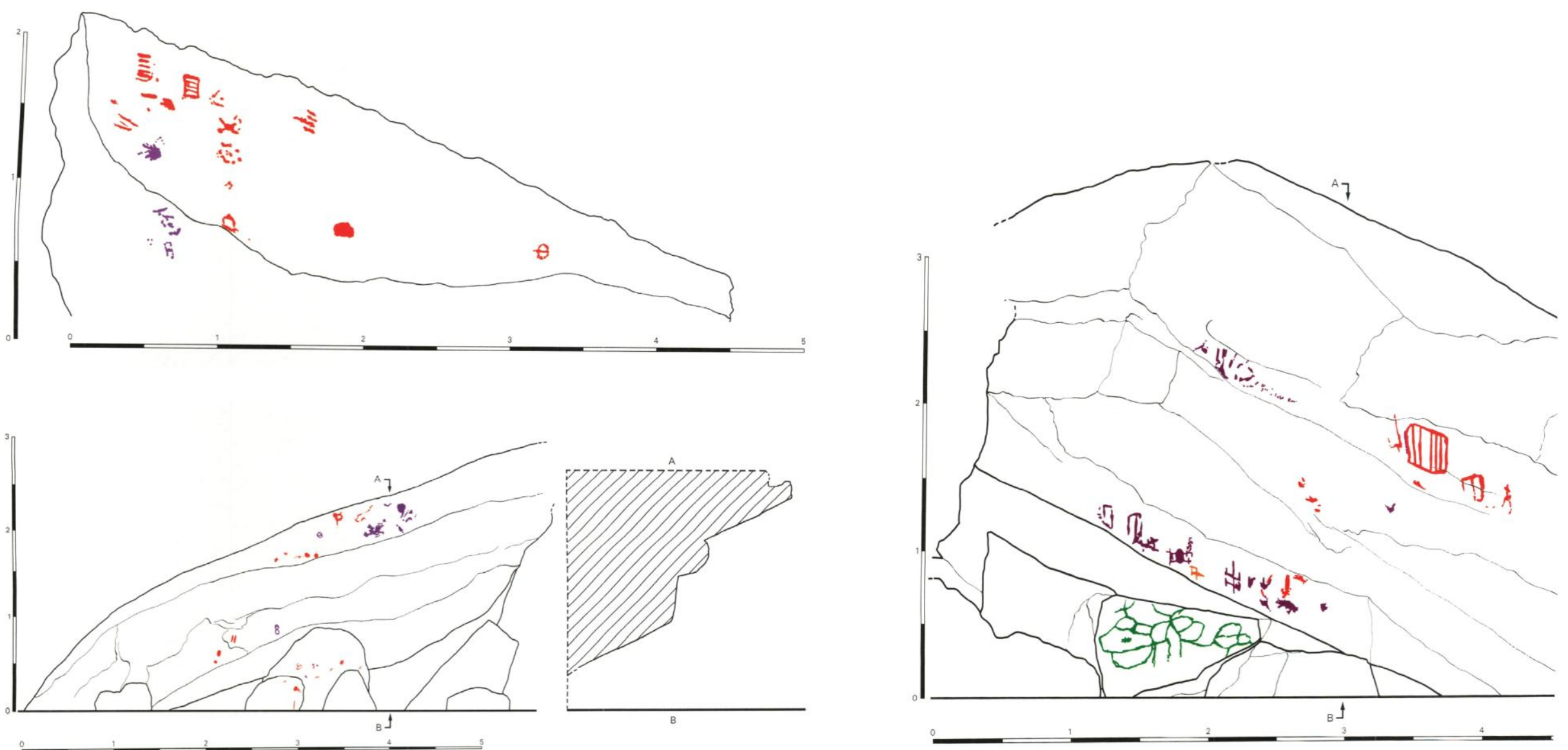

CONJUNTO III, Painel 1 e 2 


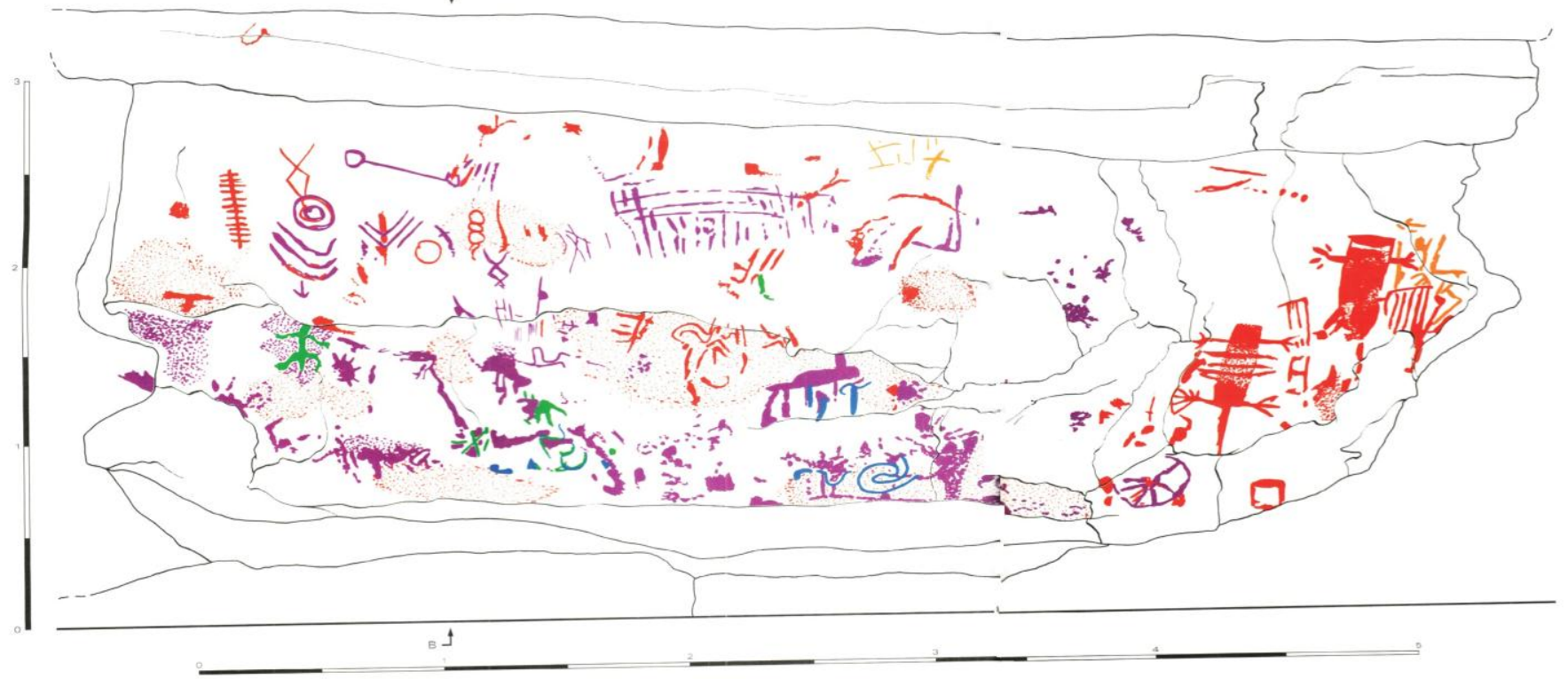

CONJUNTO IV, Painel 1 e 2

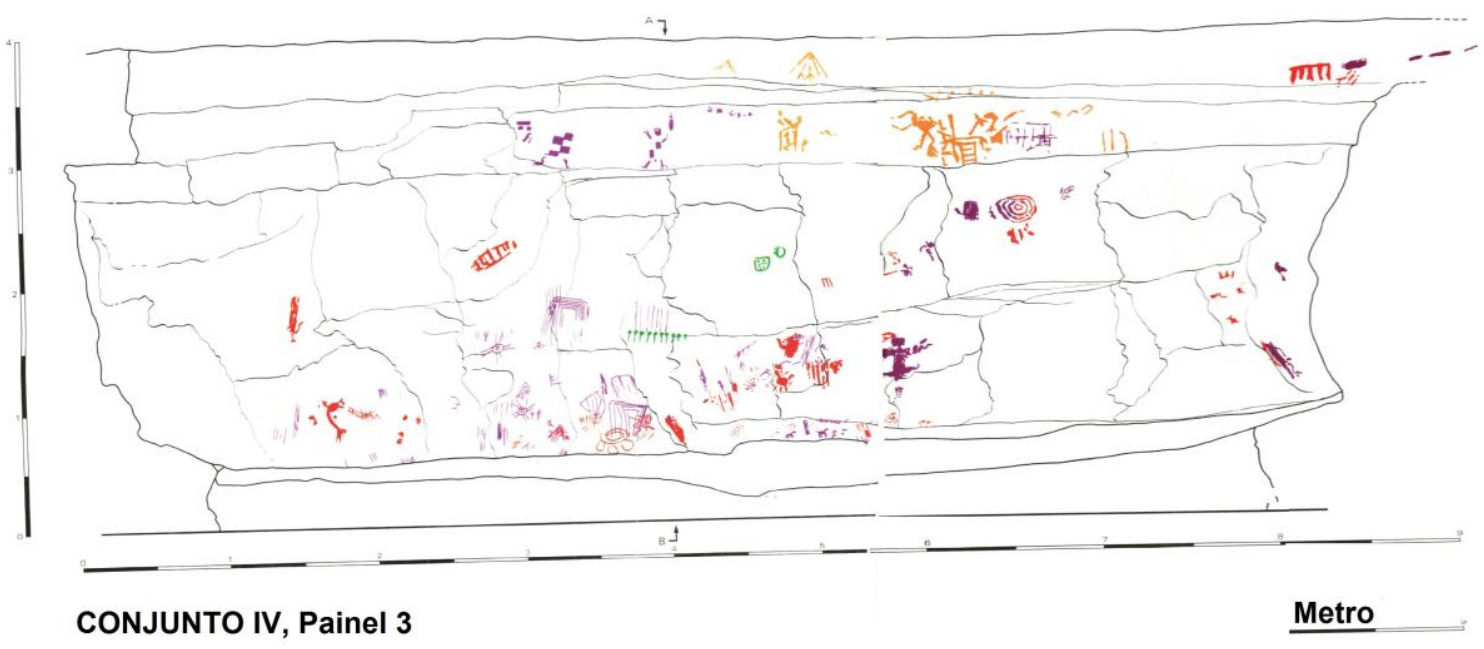




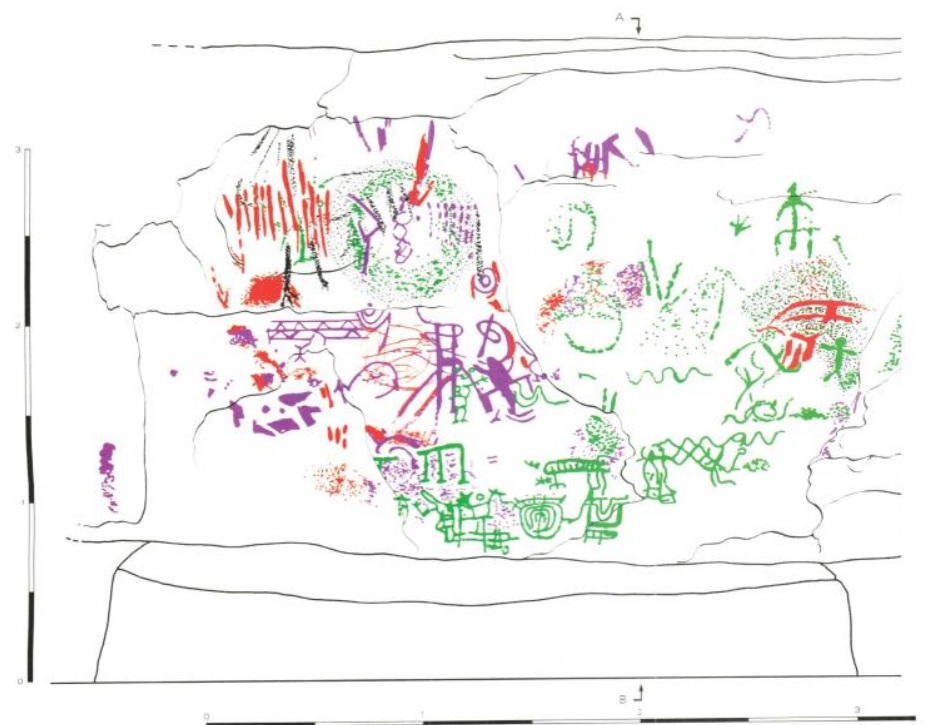

CONJUNTO IV, Painel 4

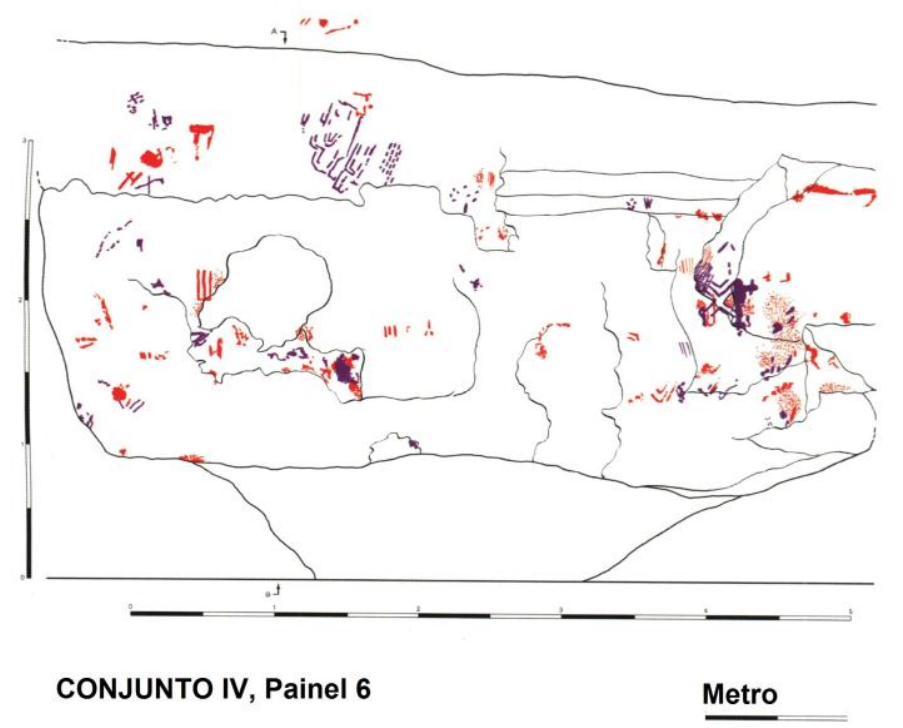

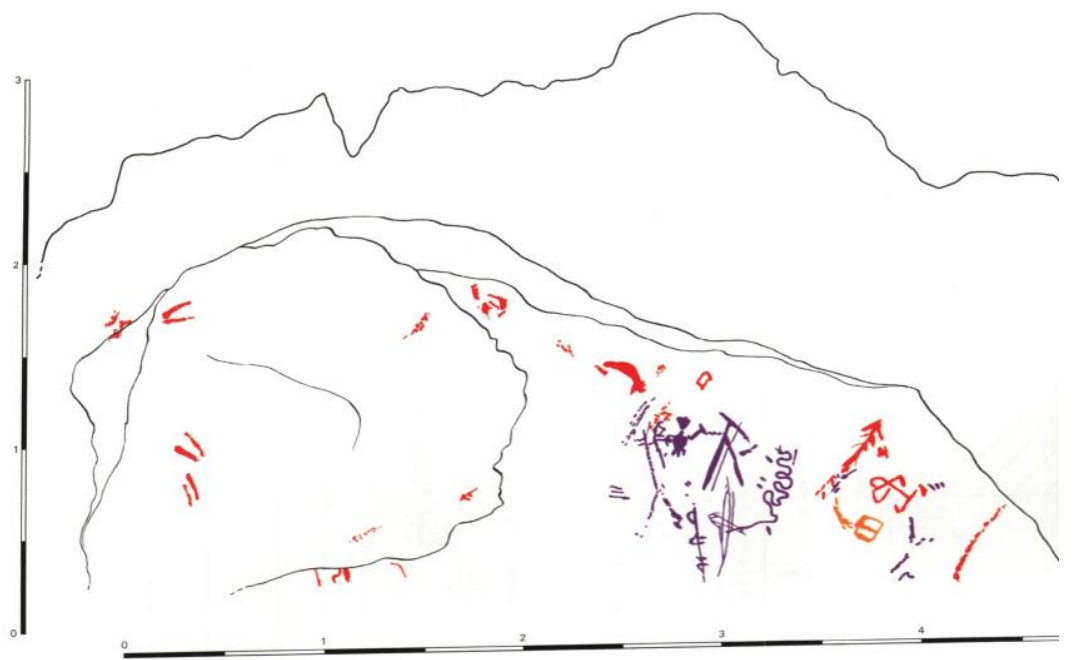

CONJUNTO IV, Painel 5

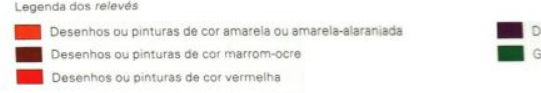


Contudo, estabelece como foco de análise a estrutura física apenas dos afloramentos rochosos CIII e CIV, [figura 8], que produz a partir do basculamento de um dos lados, um amplo e espaçoso salão central, configurando-se como a porção mais protegida do abrigo, conservando-se sombreado e bem protegido das chuvas. Ali, a abóboda é muito inclinada e a inclinação abrupta subvertical formada pela parede noroeste constitui a cobertura de uma cavidade aberta de leste a oeste (PAILLET, 2006, p.94). Este foi o local escolhido para o início das escavações com a abertura da sondagem I - quadra 13 G, [figura 13]. Neste local, ocorreu a maior parte das campanhas arqueológicas e onde foi encontrada a maioria das estruturas de fogueiras identificadas e datadas a posteriori.

Ali também se alocava a maior parcela do material lítico recuperado, da pequena quantidade de cerâmica, além de parte das evidências de manifestações parietais. As escavações foram realizadas em direção sudoeste, local onde basicamente o sedimento é arenoso e homogêneo até a proximidade da base do sítio que repousa sobre um lajeado rochoso arenítico de topografia irregular. Nos $15 \mathrm{~cm}$ mais profundos de estratigrafia sobre o lajeado, o sedimento arenoso torna-se bastante heterogêneo, pedregulhoso, de granulometria e textura variada (DeBLASIS, 1996, p. 146).

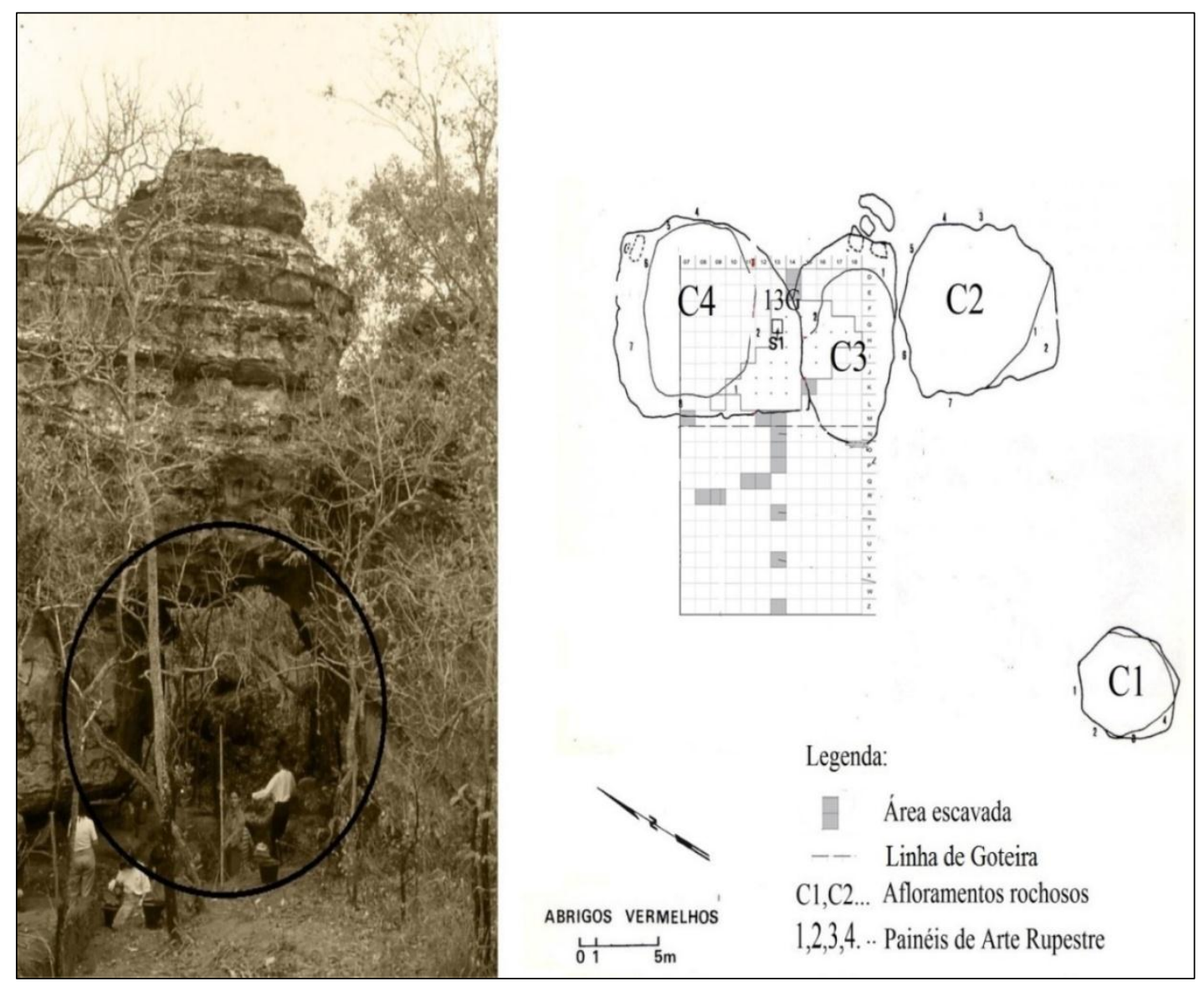

Figura 13 - Croqui esquemático da área de escavação de Abrigos Vermelhos. Foto - P. DeBlasis, S/D. 
A evidência estrutural marcante nesta área de escavação é uma certa declividade do terreno, sendo esta característica detectada ao longo dos anos das campanhas de escavação, tornando o solo quase horizontal em sua porção mais interna junto às quadras $\mathrm{G}$ e $\mathrm{H}$, enquanto que em sua porção mais externa, junto às quadras $\mathrm{J}, \mathrm{K}$ e L, a laje de arenito mergulha mais pronunciadamente, [figura 14].

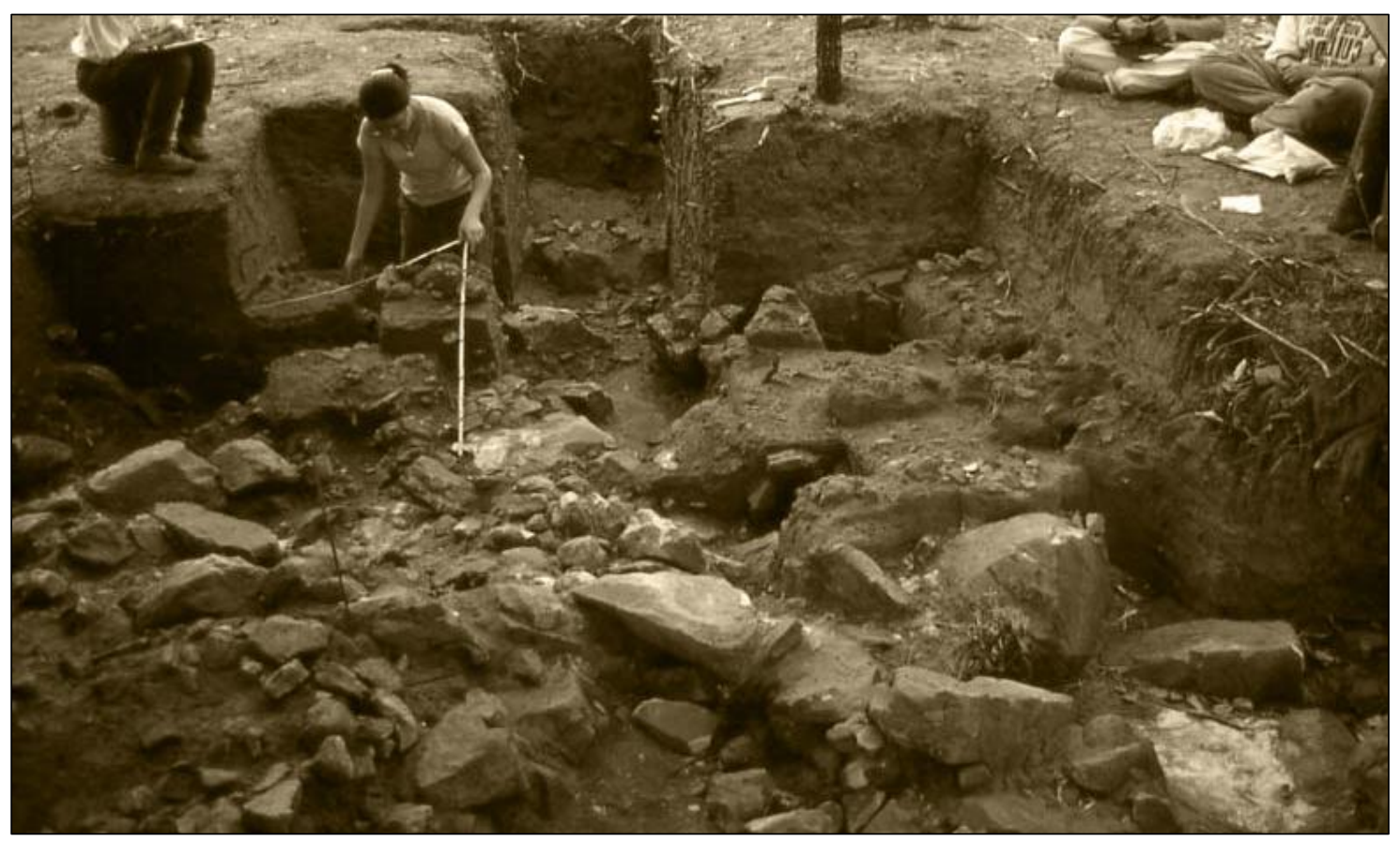

Figura 14 - Laje arenítica no limiar da área interna e externa do abrigo. Foto - P. DeBlasis, S/D.

A estrutura sedimentológica do abrigo é composta por uma camada superficial arenosa, com cerca de 5 a $10 \mathrm{~cm}$ de espessura, textura mais solta e a presença de buracos produzidos pela frequência ao longo do tempo de antas, que usam o local como dormitório. A partir desta informação, aventa-se a possibilidade que haja eventuais alterações na topografia do sedimento e o consequente aprofundamento das peças na estratigrafia, e mesmo um processo de trampling.

Segundo Gifford (1985), o processo de trampling pode "sugerir movimentação vertical de materiais arqueológicos e detritos alocados em suas matrizes sedimentares quer por ação animal, ou ação humana, sem deixar traços visíveis de movimentação" (GIFFORD, 1985, p.805).

Uma segunda camada, de composição sedimentar mais fina e areias mais homogêneas e pouco compactas, estão localizadas nas quadras referentes à porção mais reservada, que se 
estende do metro G até o metro J e atinge profundidade de até 140/150 cm. É nesta camada que estão contidas todas as fogueiras, nas quadras que perfazem um horizonte cronológico de até 2.000 AP, depositadas entre os metros G, I e J.

A partir de $140 \mathrm{~cm}$ de profundidade, nota-se na porção central do abrigo, com limite na quadra L/K, em direção à área limítrofe da porção abrigada, a mudança de coloração para uma camada marrom, que preserva a textura arenosa. Porém, esta camada apresenta material escuro, imiscui-se entre os pedregulhos do embasamento rochoso, acompanhando a declividade do terreno e prossegue para a área externa do abrigo. Apesar da coloração diferente, a textura arenosa das camadas A e B são de mesma constituição.

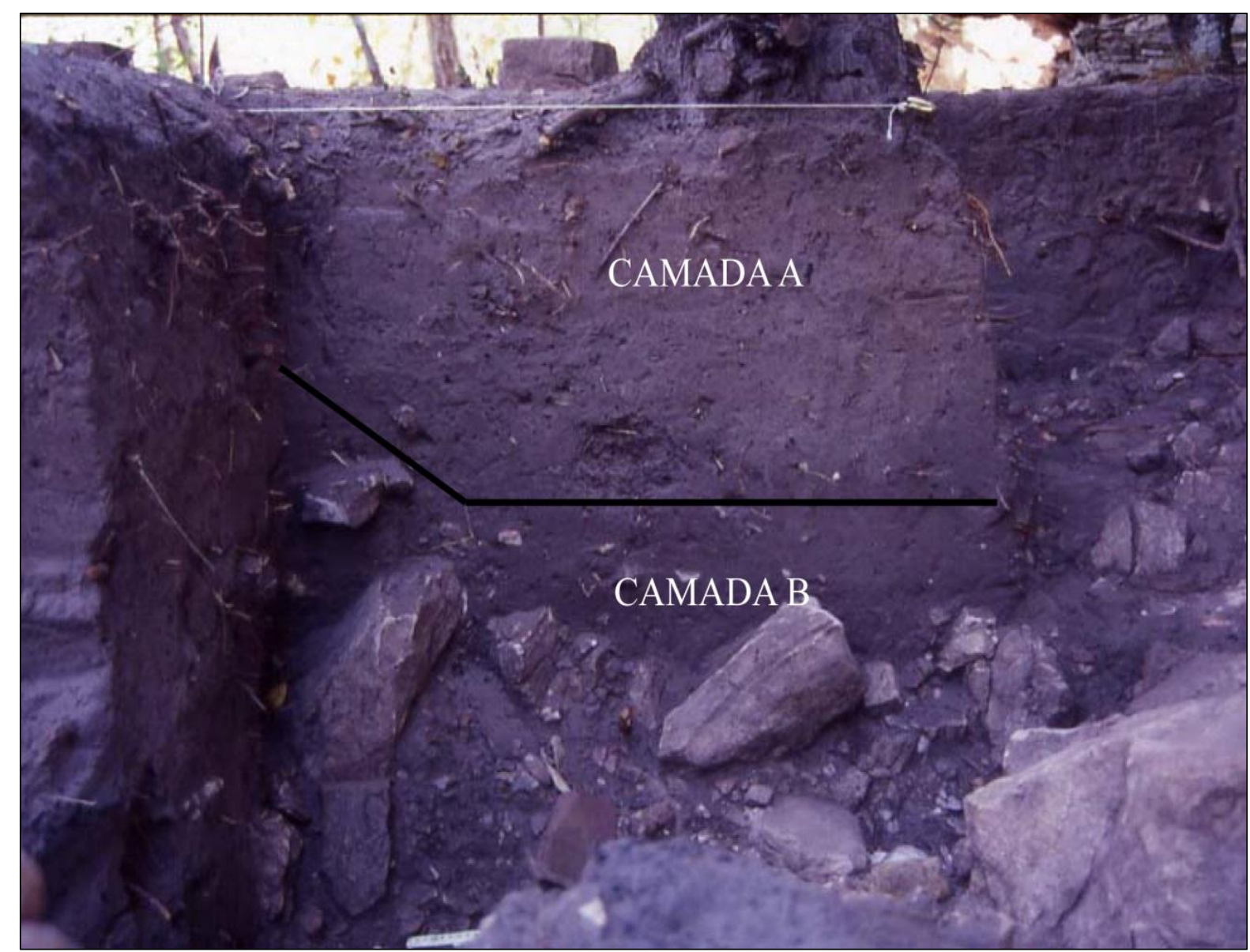

Figura 15 - Camada sedimentar dos Abrigos Vermelhos. Foto - P. DeBlasis, S/D. 


\subsection{OS MÉTODOS DE CAMPO E AS CAMPANHAS ARQUEOLÓGICAS}

Com base nas cadernetas de campo e nos relatórios produzidos ao longo dos anos das campanhas arqueológicas efetuadas em Abrigos Vermelhos, apresentamos a descrição das etapas de campo. Esse procedimento tem a finalidade de apontar as principais características estruturais do sítio arqueológico, reunindo as informações sobre as estratégias de pesquisa adotadas ao longo destas campanhas.

O método utilizado na escavação foi a abertura de uma trincheira para a observação do solo do abrigo e a declividade do embasamento rochoso dentro e fora do sítio, em direção leste-oeste. Concomitantemente a este procedimento, a escavação foi executada a partir da abertura de superfícies amplas, de modo a colocar em evidência as estruturas presentes no sítio.

A abertura da trincheira e da escavação por meio de superfícies amplas permitiu abordar em conjunto a dimensão estratigráfica e espacial do abrigo. Esse processo forneceu elementos para pensarmos se o pacote estratigráfico permaneceu homogêneo ou sofreu variações ao longo do tempo, e, se a partir de tais elementos, é possível isolar áreas de atividades.

O resultado destas intervenções resultou em uma coleção lítica com 4.253 peças que foram distribuídas na estratigrafia e 3.997 peças analisadas tecnologicamente, além de um conjunto de informações oriundas das campanhas de escavação. Campanhas organizadas em torno de uma malha de quadriculamento dos materiais arqueológicos e das coordenadas $\mathrm{x}, \mathrm{y}$ e z, agora servem às análises espaciais realizadas neste capítulo.

Campanha de 1991 - A primeira campanha realizada em Abrigos Vermelhos consta da abertura de uma sondagem realizada na quadra 13 G, [figura 13], configurando-se o ponto inicial do que se consolidaria futuramente como a linha da trincheira 13. Como resultado de um levantamento rápido efetuado no abrigo foi realizada uma decapagem de 6 metros quadrados que atingiu profundidade de 30-40 cm nas quadras adjacentes à linha 13 , situadas na base do painel I do conjunto C IV de arte rupestre (PAILLET, 2006, p.116). Neste local, efetuaram-se, na sequência, as sucessivas campanhas arqueológicas, confirmando o potencial do abrigo quanto à intensidade das ocupações e suas características quanto à utilização do espaço e das atividades desenvolvidas. 
Campanha de 1993 - Realizou-se a ampliação da escavação dirigida para a parte central da área abrigada, do qual 15 metros quadrados foram decapados, integrando-se aos 4 metros quadrados anteriormente escavados na campanha de 1991. Na porção externa do abrigo foi efetuada uma sondagem de 1 metro quadrado na quadra 13 O, área que se encontra sombreada no período da manhã até por volta das 11:00 horas no inverno. Foram abertas as quadras 14, 15 I e J, ampliando lateralmente as dimensões da escavação no salão central do abrigo. Nesta campanha principiaram evidências de irregularidade do embasamento rochoso que compõe o abrigo. Também foram notados torrões de carvões bastante dispersos, tomando parte abundante do solo e denotando dispersão dos vestígios arqueológicos dentro da área abrigada.

Campanha de 1995 - Na campanha de 1995, iniciou-se a escavação sobre as estruturas de combustão entre as quadras 12 e $13 \mathrm{~J}$, além da quadra $13 \mathrm{~K}$, e foi estendida a linha de trincheira 13 até a quadra 13 O. A escavação se aproximou definitivamente da porção limítrofe entre a área interna e externa do sítio ao serem abertas as quadras $13 \mathrm{~K}, \mathrm{~L}, \mathrm{M}, \mathrm{N}$, havendo a identificação e início da evidenciação das grandes fogueiras que estavam instaladas na entrada do abrigo neste setor. As novas áreas abertas referem-se às quadras $12 \mathrm{I}$ e $\mathrm{J}$ e a ampliação da trincheira na linha 13, abrindo as quadras 13 K,L,M,N e O, tornando evidente um processo de intensa atividade nesta área do sítio.

Campanha de 1996 - Na campanha de 1996, as grandes fogueiras das quadras 14 L e K foram totalmente evidenciadas e decapados mais 12 metros quadrados a partir da linha da trincheira 13 na área contigua entre a porção abrigada e não abrigada. As fogueiras se aproximaram do embasamento rochoso ou de grandes blocos quando dentro da área protegida do abrigo. Nesta escavação foi evidenciado o embasamento rochoso na zona central do abrigo e na sondagem efetuada na quadra $13 \mathrm{O}$, na porção externa do abrigo, a mais de um metro de profundidade.

Campanha de 1999 - As intenções nesta campanha consistiram em alcançar a laje arenítica junto à área externa imediata do abrigo, delimitando a extensão da área de ocorrências na porção externa no lado sul do abrigo. As atividades desenvolvidas foram a continuação da escavação na área limítrofe à linha de goteira 13 K,L,M,N até alcançar a sondagem realizada em $13 \mathrm{O}$ e áreas contíguas 13 e 12L, 15 L e M, 13 e 12 K. Poucas novas áreas foram abertas neste trecho do sítio, apenas 3 metros $^{2} 12 \mathrm{M}, 11 \mathrm{~K}$ e $10 \mathrm{~L}$. As escavações alcançaram a laje a cerca de um metro de profundidade por boa parte da área aberta. Foram coletadas amostras de 
carvão para datação em 4 das 12 fogueiras presentes neste trecho do sítio, confirmando a zona de maior adensamento de material e estruturas do sítio.

A síntese do resultado dos anos de pesquisas efetuadas na área do abrigo pode ser melhor compreendida com a visualização das quadras escavadas e a concentração de material presente no Grid com a distribuição do material arqueológico [figura 16].

\begin{tabular}{|c|c|c|c|c|c|c|c|c|c|c|c|c|c|c|}
\hline Quadras & 7 & 8 & 9 & 10 & 11 & 12 & 13 & 14 & 15 & 16 & 17 & 18 & \multirow[b]{7}{*}{ Escala } & \\
\hline A & & & & 75 & & & & & & & & & & \multirow{22}{*}{ 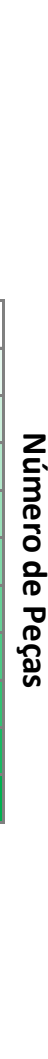 } \\
\hline B & & & & & & & & 4 & & & 34 & & & \\
\hline C & & & & & & & 1 & 3 & & & & & & \\
\hline D & & & & & & & 1 & 56 & & & & & & \\
\hline \multicolumn{13}{|l|}{ E } & & \\
\hline $\mathbf{F}$ & & & & & & & 1 & 1 & & & & & & \\
\hline G & & & & & & & 14 & & & 20 & 3 & 2 & 1 & \\
\hline H & & & & & & & 29 & 239 & 56 & 38 & 35 & & 40 & \\
\hline I & & & & & 11 & 1 & 90 & 111 & 63 & 249 & & & 79 & \\
\hline J & & & & & 25 & 4 & 201 & 210 & 134 & 31 & & & 117 & \\
\hline $\mathbf{K}$ & & & & 90 & 94 & 110 & 150 & 112 & & & & & 156 & \\
\hline $\mathbf{L}$ & & & 129 & & 383 & 321 & 389 & 49 & & & & & 195 & \\
\hline M & 111 & & & & & 210 & 203 & & & & & & 234 & \\
\hline $\mathbf{N}$ & & & & & & & 64 & & & & & & 273 & \\
\hline 0 & & & & & & & 130 & & & & & & 311 & \\
\hline $\mathbf{P}$ & & & & & & & 8 & & & & & & 350 & \\
\hline $\mathbf{Q}$ & & & & & & & & & & & & & 389 & \\
\hline $\mathbf{R}$ & & & & & & & & & & & & & & \\
\hline S & & & & & 1 & & 33 & & & & & & & \\
\hline $\mathbf{T}$ & & & & & & & & & & & & & & \\
\hline $\mathbf{U}$ & & & & & & & & & & & & & & \\
\hline V & & & & & & & 14 & & & & & & & \\
\hline
\end{tabular}

Figura 16 - Distribuição dos materiais arqueológicos nas quadras escavadas.

Há concentração de material em algumas quadras específicas, mas que não denotam pontos isolados de deposição, tais quais as quadras $7 \mathrm{M}, 9 \mathrm{~L}$ e $14 \mathrm{H}$, enquanto a rarefação de material é evidente na porção não abrigada do sítio. É importante frisar que o delineamento da escavação privilegiou a abertura de quadras na porção interna dos conjuntos de afloramentos rochosos CIII e CIV, podendo enviesar a análise. Não obstante, foram realizadas uma série de sondagens no setor externo do sítio, confirmando que os vestígios rarefazem de fato conforme os pontos de sondagens se afastam da porção mais abrigada do sítio. 


\subsection{AS ESTRUTURAS DE COMBUSTÃO E A CRONOLOGIA DO SÍTIO: QUATRO SETORES DISTINTOS}

Os resultados de análise são provenientes do quadro de datações originadas a partir de coletas em diferentes estruturas e fogueiras com diferentes níveis estratigráficos e pontos de coleta no espaço interno e externo do sítio. Embora haja um amplo desenvolvimento nas últimas décadas dos estudos a respeito dos processos formativos de sítio a partir da perspectiva da geoarqueologia (HARRIS, 1989) e, neste caso em especial, de trabalhos que tratam de processos de formação de abrigos sob rocha (RICK, 1976; VILLA, 1982, 1983; ARAUJO et. al, 2008), levou-se em consideração apenas as análises provenientes das datações radiométricas e análises que consideram medidas e pesos das peças distribuídas na estratigrafia, além das remontagens efetuadas.

O quadro de datação estabelecido indica quatro setores de deposições organizados em torno da distribuição das datações radiométricas, fator que deve ser assumido como uma possibilidade de análise, assumindo-se certa contemporaneidade dos fatos em torno da organização do quadro cronológico, da disposição na cultura material no espaço e da tipologia das estruturas de combustão. Não obstante, alguns processos de formação de sítio são observados e intercalados a estas classificação, tais quais os processos de inversão estratigráficas presentes nas quadras 13I, $13 \mathrm{~J}, 13 \mathrm{~L}$, [figura 17 a], podendo significar que o abrigo não apresenta um processo de deposição estratigráfica regular, indicando fases erosivas, inconformidade com a sequência estratigráfica e uma superfície de destruição causada por fatores antrópicos e não antrópicos.

Outro fator a ser considerado é a sobreposição de cultura material sobre os mesmos pontos de coleta de carvão das estruturas de fogueiras utilizadas nas datações radiométricas. Este processo de acúmulo de material indica um processo de mistura de materiais provenientes de momentos deposicionais distintos que devem variar em intensidade, velocidade e volume de material depositado. Não obstante, também demonstra certa recorrência e insistência em reocupar os mesmos locais dentro do sítio, como um indicativo de ação humana e não simplesmente de deposição e arranjo natural.

Isto posto, a partir da coleta de carvão proveniente de 15 datações radiométricas para o sítio $^{2}$, disponíveis nas figuras [17 a e 17 b], é possível observar intervalos de ocupação do

2 Todas as amostras são de carvão e madeira provenientes de fogueiras ou estruturas de combustão. As idades por ${ }^{14} \mathrm{C}$ são idades convencionais AP. As datas calibradas são obtidas a partir do programa CALIB (Stuiver e Reimer, 1993), sendo considerada a correção do hemisfério sul (-40 anos), (FONTUGNE et al., 2006, p.48). 
espaço interno e externo do sítio conforme os parâmetros cronológicos estabelecidos. Duas análises foram realizadas, tornando-se complementares. A primeira organiza o quadro de datação por meio da ordem estratigráfica e permite inferir uma continuidade estratigráfica de deposição de material em períodos e setores específicos dentro do sítio. A segunda organiza o quadro de datação conforme os intervalos das idades calibradas e apresenta indícios de continuidade de ocupação entre 1.000 AP e 4.000 AP e indícios de ruptura de horizontes com datações que se iniciam a partir de $1.000 \mathrm{AP}$, [figura $17 \mathrm{~b}$ ].

As datações revelam um momento mais antigo localizado na área externa do abrigo entre as quadras $13 \mathrm{~V}$ e $13 \mathrm{~S}$, seguido por áreas localizadas no limite externo da área de entrada para o salão central que perfazem as quadras $13 \mathrm{~N}$ e $13 \mathrm{~L}$, e por uma série de datações que se distribuem na área central do abrigo até alcançar a porção mais recôndita do abrigo, além de alcançar as datações mais recentes nas quadras $13 \mathrm{G}, 17 \mathrm{G}, 11 \mathrm{~J}$, evidenciando um deslocamento de atividades do espaço externo para o espaço abrigado do sítio até a porção mais afastada da área de entrada do abrigo.

As estruturas de fogueiras estão distribuídas por todo o interior do salão central. Consta uma série delas com formato, tamanho e localização distintas. As que estão alocadas no setor mais abrigado estão melhores preservadas e não sofrem sobreposições, enquanto aquelas localizadas no limiar entre a área abrigada e não abrigada sofrem uma série de sobreposições e mesmo inversões estratigráficas que podem ser avistadas nas quadras 13I, 13 J, 13 L, [figura 17 a], indicando uma área em que a ação dos agentes naturais persiste e extrapola a possibilidade de detecção de períodos de ocupações específicos. 


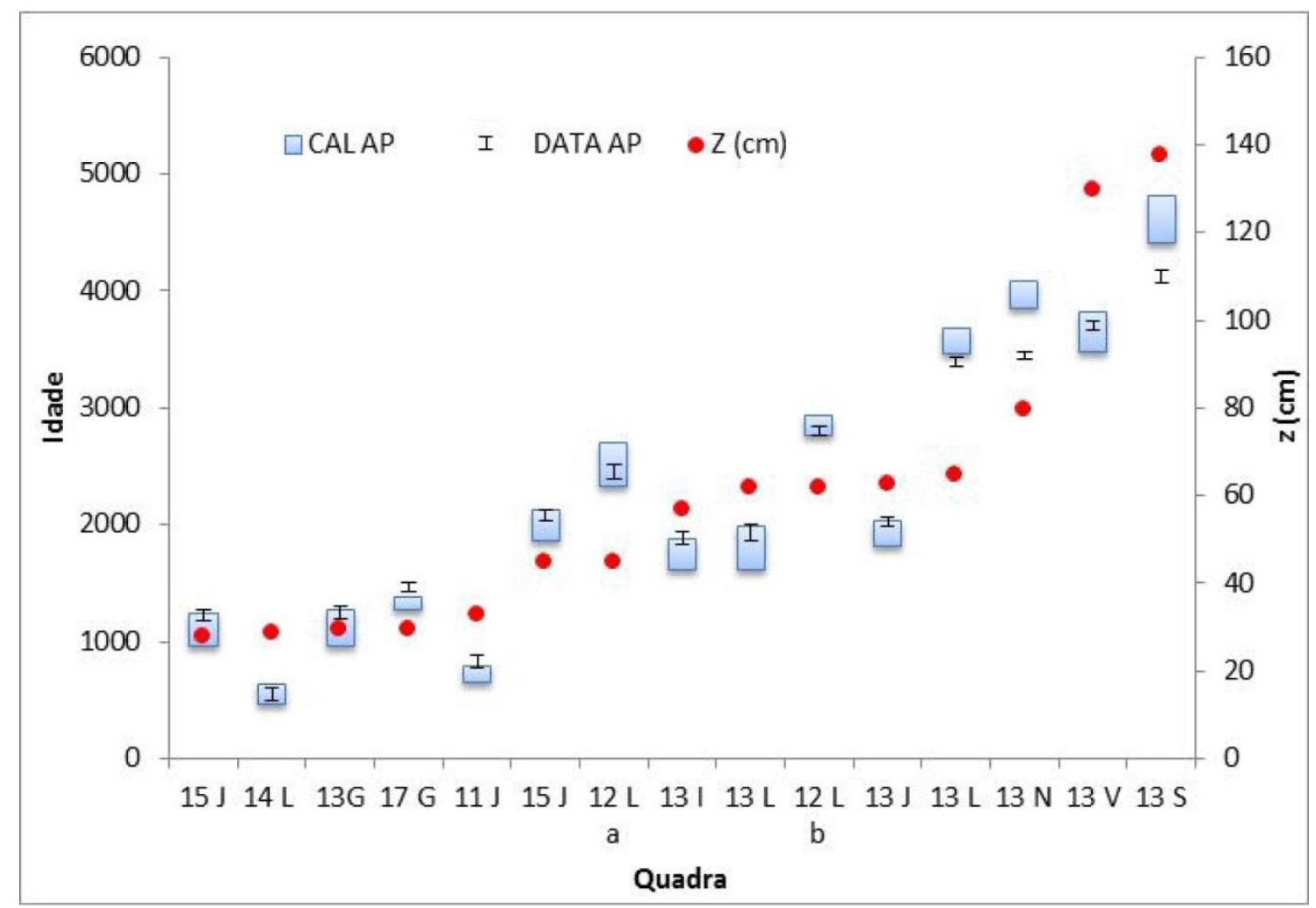

(a) Datas organizadas conforme ordem cronológica

(b) Datas organizadas conforme intervalo de calibração

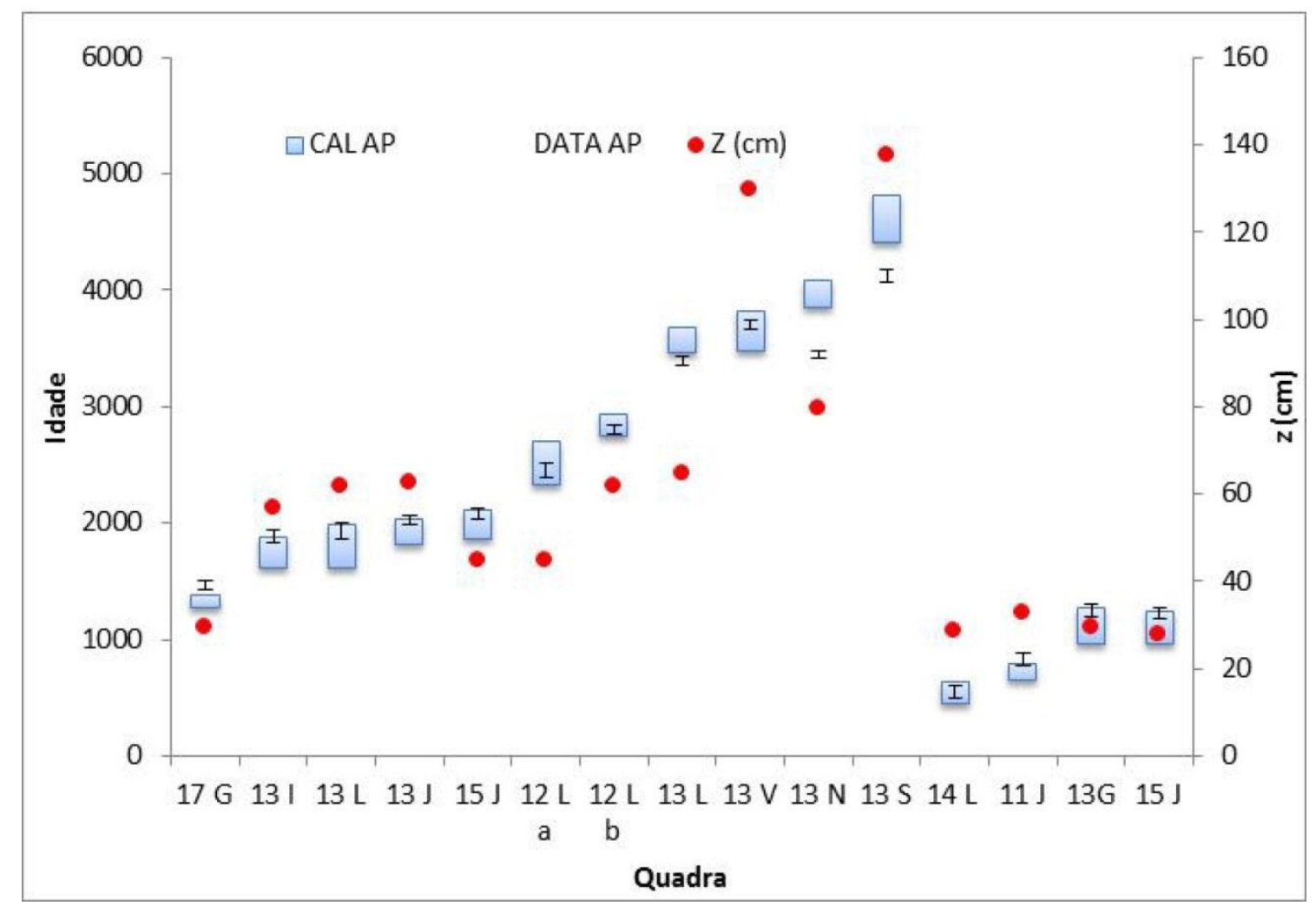

Figura 17 - Quadro de datações do sítio. 
Em torno da cronologia notam-se quatro setores distintos perfazendo três setores no espaço abrigado, e uma área de deposição mais antiga fora. A título de organização do trabalho, denominamos estas áreas setores A, B, C, D. Isto não significa que tratam-se de áreas rígidas de ocupação como já expostas, mas que estão organizadas sob o ponto de vista da cronologia. Em torno desta divisão, é possível observar que a temporalidade e as formas de ocupação modificam-se ao longo do tempo. Além disso, fornecem elementos para que as matérias-primas líticas e a cerâmica sejam discutidas espacialmente e estratigraficamente.

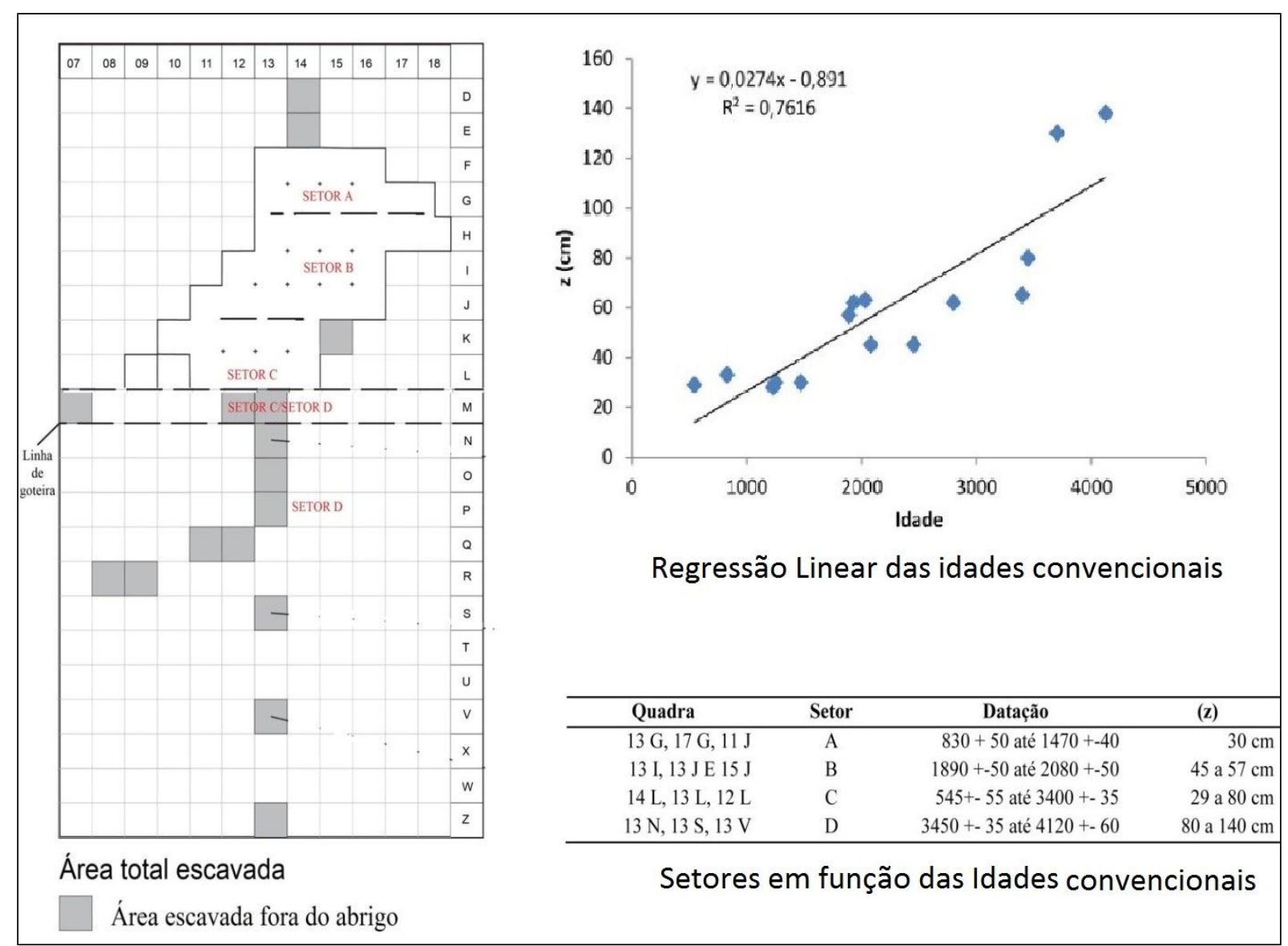

Figura 18 - Croqui organizado conforme a ordem cronológica. 
3.3.1 SETOR A - Horizonte cronológico (830 +- 50 AP até 1470 +- 40 AP)

O setor A é composto pela parte mais abrigada e níveis estratigráficos mais altos, atingindo o embasamento rochoso em torno de $150 \mathrm{~cm}$, formado por camada arenosa misturada à defecação animal e muita dispersão de carvão. Comporta as fogueiras das quadras $13 \mathrm{G}, 17 \mathrm{G}$ e se estende até a quadra $11 \mathrm{~J}$, constituindo fogueiras únicas em seu tipo circulares, pequenas e bem estruturadas. Os vestígios arqueológicos são rarefeitos nesta área, [figura 14].

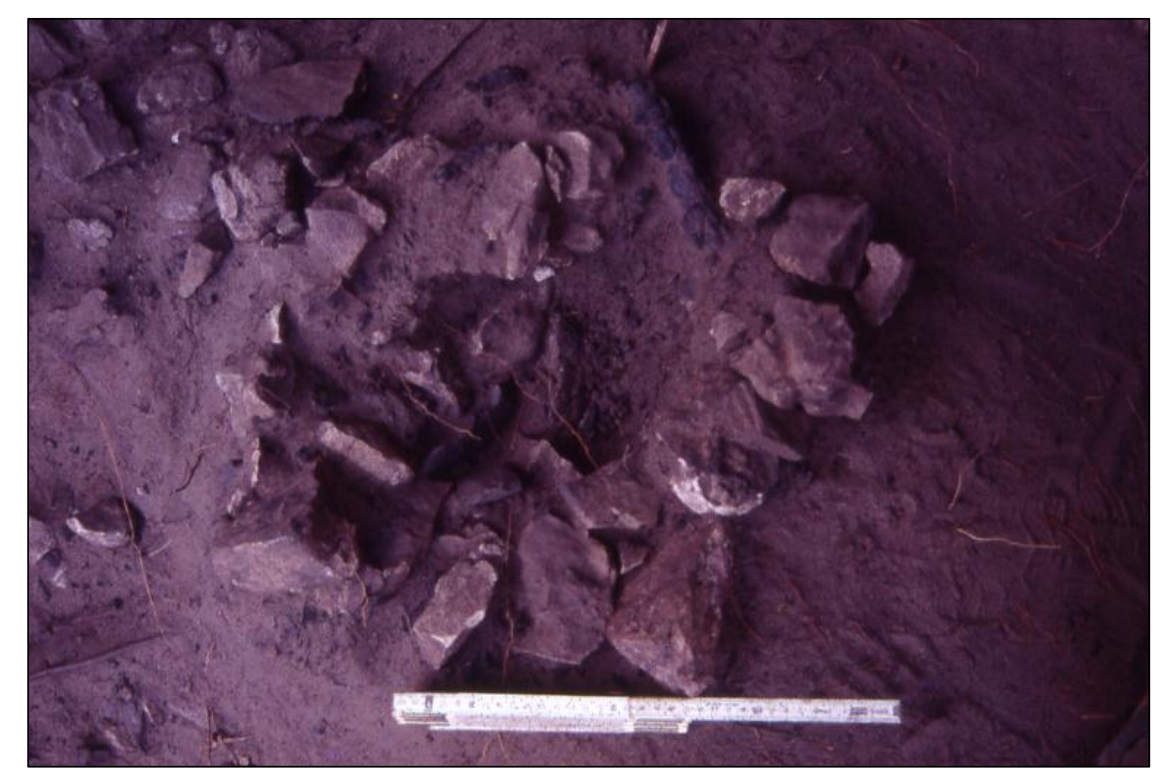

Figura 19 - Estruturas de combustão das quadras 13G, 17 G e 11 J. Foto - P. DeBlasis, S/D.

\subsubsection{SETOR B - Horizonte cronológico (1890 +- 50 AP até 2080 +-50 AP)}

O setor B é composto pela parte central do abrigo e níveis estratigráficos que podem atingir até $170 \mathrm{~cm}$. As camadas arenosas A e B começam a misturar-se em algumas quadras e há grande dispersão de carvões, mostrando que sob o embasamento rochoso reúne blocos arredondados com indícios de processo de erosão que não parecem ter sido deslocados, enquanto que, as pedras das fogueiras apresentam arestas e parecem transportados, não encontrando-se presas ao embasamento rochosso.

As fogueiras localizadas no setor B apresentavam grande porte, encontram-se organizadas em círculo com blocos de arenito silicificado ao redor e com espessas lentes de 
carvão, correspondendo às quadras $13 \mathrm{I}, 13 \mathrm{~J}$ e $15 \mathrm{~J}$. Os vestígios arqueológicos são abundantes e comportam fragmentos cerâmicos em níveis estratigráficos elevados.

\subsubsection{SETOR C - Horizonte cronológico ( 545 +- 55 AP até 3400 +-60 AP)}

$\mathrm{O}$ setor $\mathrm{C}$ é representado pela área contígua entre a área externa e interna do abrigo e situa-se no local em que o embasamento rochoso sofre declividade, atingindo cotas de até 200 $\mathrm{cm}$. Este é o local onde há a evidência de uma camada inferior mais escura, associada aos blocos areníticos do embasamento rochoso. Nela estão presentes estruturas de grandes fogueiras sobrepostas com variados horizontes de datação, presentes nas quadras $14 \mathrm{~L}, 13 \mathrm{~L}$ e $12 \mathrm{~L}$.

Este setor apresenta-se imediatamente em contato com a área externa do abrigo cuja datação estabelecida para a quadra $13 \mathrm{O}$ é compatível com as datas das quadras L. Deste modo, é possível inferir a existência de um horizonte de transição entre a área externa e interna para a linha de goteira do sítio que pode variar ao longo do tempo, mostrando uma superposição no espaço, usado continuamente, sem que haja uma compartimentação funcional rígida.

Os achados cerâmicos das quadras 14 L e K consolidam a interpretação de um nível de ocupação cerâmica em profundidades que variam entre 105 e $125 \mathrm{~cm}$. Entretanto, há sugestão que esta seja uma área usada múltiplas vezes ao longo do tempo para diferentes atividades, local em que lascar e trabalhar com corantes é prática frequente. É relevante informar que nas quadras $12 \mathrm{~L}$ e $11 \mathrm{~L}$ há quatro fragmentos das paredes do abrigo em profundidade de $159 \mathrm{~cm}$ e que na quadra $7 \mathrm{M}$, um arenito pintado, proveniente de um pedaço de parede caído foi encontrado em profundidade de $132 \mathrm{~cm}$, demonstrando que a arte rupestre parece ter sido atividade ininterrupta ao longo de tempo desde horizontes estratigráficos anteriores às datações de períodos em que ocorrem os vestígios cerâmicos. 


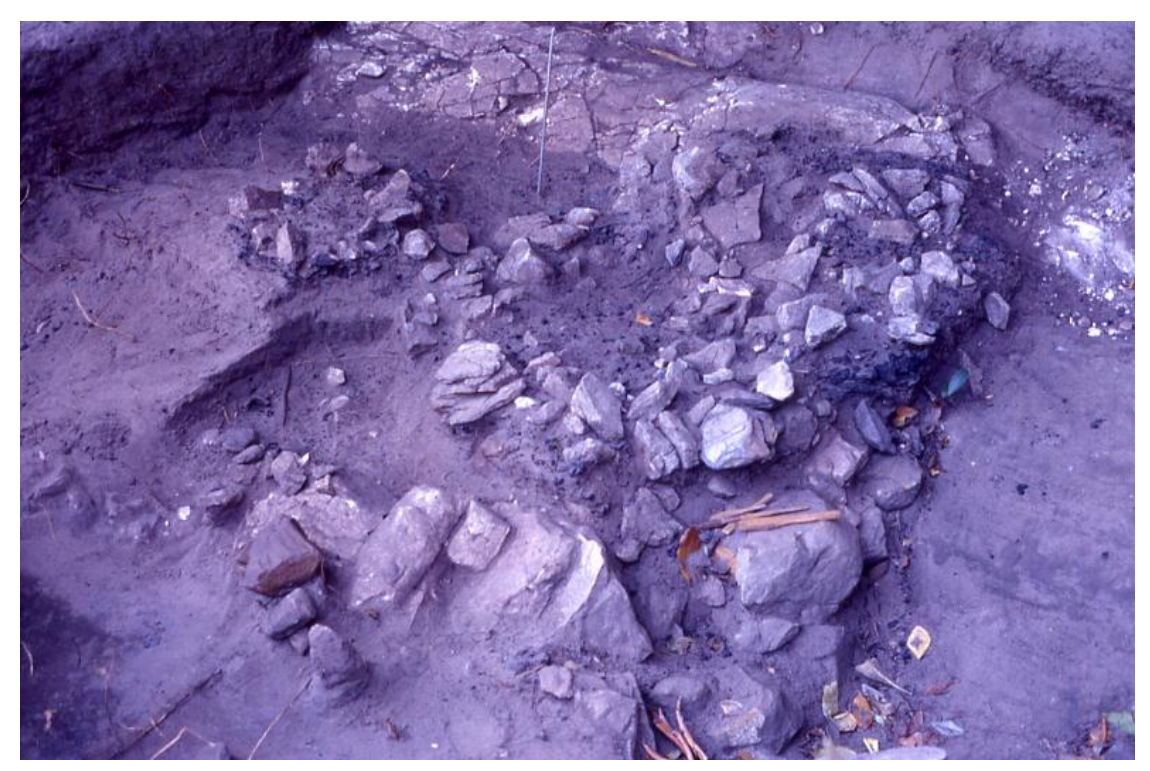

Figura 20 - Estruturas de combustão nas quadras 14 L, 13 L, 12 L. Foto - P. DeBlasis, S/D.

\subsubsection{SETOR D - Horizonte cronológico (3450+-35 AP até 4120 +- 60 AP)}

O setor D comporta horizonte cronológico com as datações mais antigas situadas no espaço não abrigado do sítio: quadras $13 \mathrm{~N}, 13 \mathrm{~S}$ e $13 \mathrm{~V}$, com profundidades atingindo até $240 \mathrm{~cm}$. Em contraposição as estruturas de fogueiras bem definidas da área interna do abrigo, na área externa do abrigo havia uma multiplicidade de fogueiras menores, menos estruturadas e com lentes de carvão menos evidentes, com muitas pedras desarticuladas em torno de manchas irregulares de cinzas e carvões.

Tendo em vista que há uma série delas dispersas, a multiplicidade destas estruturas no espaço externo e em profundidades mais acentuadas, indica ocupações recuadas do abrigo ao longo do tempo. De modo que as diferenças das estruturas, posições e composição das fogueiras podem ser vistas como a produção diferenciada do espaço em relação ao abrigado. Esta conjuntura abre margem para a consideração de que estas ocupações privilegiassem a relação com o fogo em curtos episódios e em espaços abertos, que envolviam as áreas centrais e circulares envolvidas pelos conjuntos de afloramentos rochosos dos Abrigos Vermelhos. 


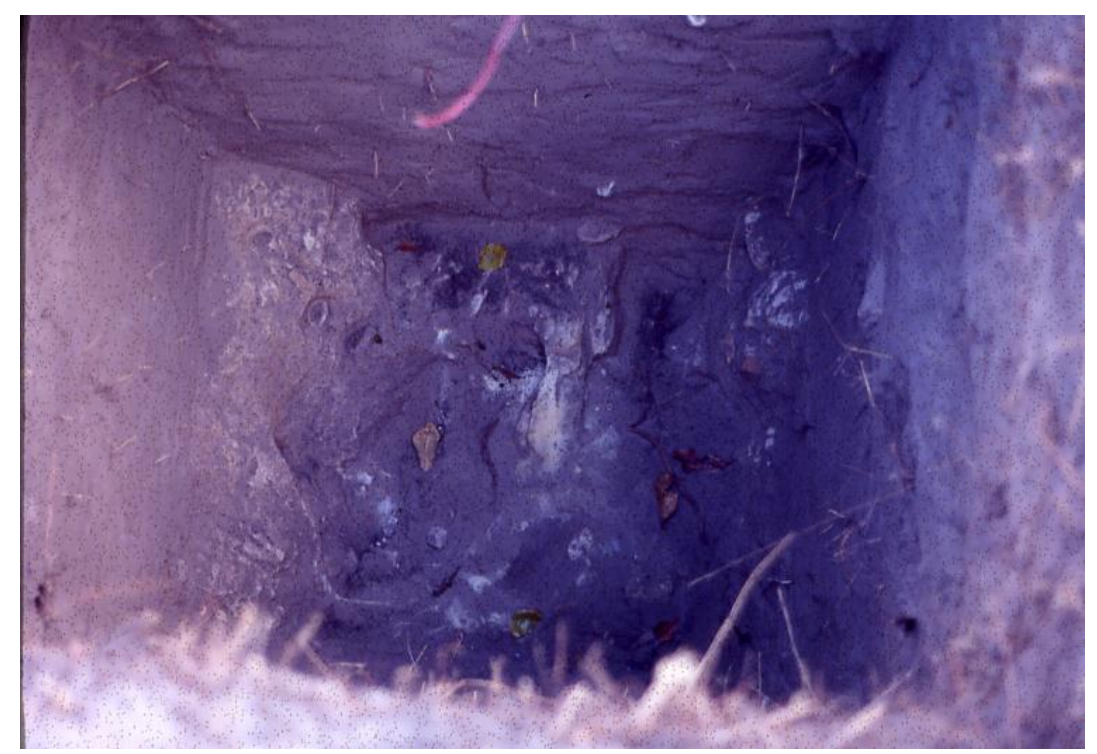

Figura 21 - Estruturas de combustão no setor externo do sítio. Foto - P. DeBlasis, S/D.

\subsection{ESTUDOS DE PROCESSOS FORMATIVOS: HÁ HORIZONTES CRONOLÓGICOS PRESERVADOS?}

Nenhum processo específico de deposição material pode apoiar-se apenas na comparação direta entre os vestígios arqueológicos e as estruturas presentes do espaço. A informação de que peças podem sofrer um gradual deslocamento é importante para lidarmos com o fenômeno da sobreposição e mistura de materiais arqueológicos dentro do abrigo e também como estes se comportam em relação às estruturas de combustão encontradas.

Neste sentido, lidamos com a possibilidade do aprofundamento de peças causada pelo pisoteamento de humanos e animais, pela presença de raízes e pela qualidade do sedimento. $\mathrm{O}$ processo de aprofundamento das peças na estratigrafia não é um fenômeno facilmente identificado no registro arqueológico, sendo dependente basicamente de quatro fatores referentes: "o nível de compactação do sedimento, a espessura dos depósitos que cobrem as peças, o peso e tamanho das peças” (VILLA, 1983, p.275).

Considera-se necessário avaliar a distribuição das peças em função da natural inclinação do embasamento rochoso, das características do sedimento arenoso mais e menos solto na porção abrigada e na menos abrigada. Além disso, é preciso validar as médias de peso e dos tamanhos dos vestígios arqueológicos que podem favorecer o processo de manutenção de peças maiores na estratigrafia e o deslocamento vertical de peças menores, conforme experimentos realizados em outros abrigos rochosos (STOCKTON, 1973, p.115). 
Este processo causa um efeito conhecido como chão de lascas, ou, "a acumulação anormal de peças em cima do embasamento rochoso" (ARAUJO, 1995, p.22).

Ao considerar este tipo de estudo não podemos escapar da necessidade de documentar os eventos arqueológicos que tentamos explicar, ao mesmo tempo em que observa-se que as relações entre eles e o passado cultural não são diretas. Para interpretar corretamente alguns aspectos do registro arqueológico é necessário entender processos externos ao sistema do passado sociocultural, e neste sentido, deve-se procurar compreender o processo de formação do registro arqueológico (SCHIFFER, 2010, p.29).

A sequência desta análise foi realizar remontagens com o propósito de testar se os vestígios apresentam a propensão de permanecer próximos, reforçando o argumento de que existem estruturas e áreas de atividades preservadas. Ou, se, de outro modo, apresentam a característica de que as misturas de materiais sejam evidentes, de sorte que, não caracterizem áreas de atividade, com razoável segurança.

A primeira análise estabelecida foi a distribuição geral das peças na estratigrafia do sítio ao longo da trincheira 13, [Figura 22] e da distribuição do material dentro do espaço abrigado do sítio, [Figura 23]. Em seguida, cada matéria-prima lítica e fragmentos cerâmicos foram alvo de análises distributivas individualizadas, apresentadas na sequência das áreas de captação de recursos já expostas no capítulo II e dos suportes que caracterizam estas matériasprimas.

Nesta respectiva ordem, será apresentada a análise do sílex e do arenito de fina granulometria, ambos recolhidos ao longo do rio Vermelho. A seguir, apresentaremos a análise do arenito de grossa granulometria, extraído de afloramentos da área central da Cidade de Pedra, em seguida virá a Rocha Verde, material proveniente das cercanias do Pantanal, será feita a análise do óxido de ferro, encontrado por toda a Cidade de Pedra e por fim, será exposta a distribuição do material cerâmico, considerada elemento crucial para estabelecermos um horizonte cronológico associado as ocupações ceramistas. 


\section{Perfil estratigráfico do sítio e distribuição das peças em estratigrafia}

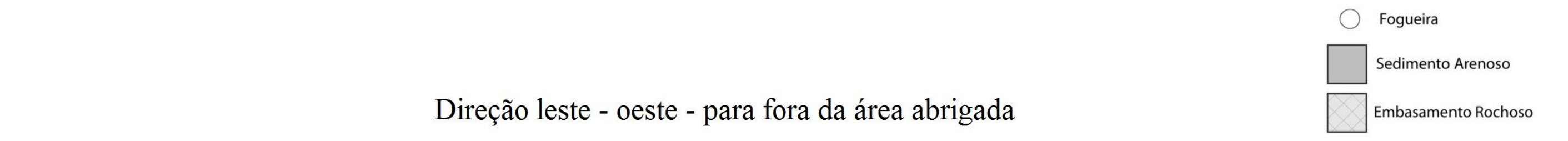

Escala Vertical

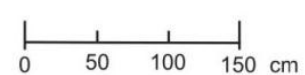

LINHA DE GOTEIRA
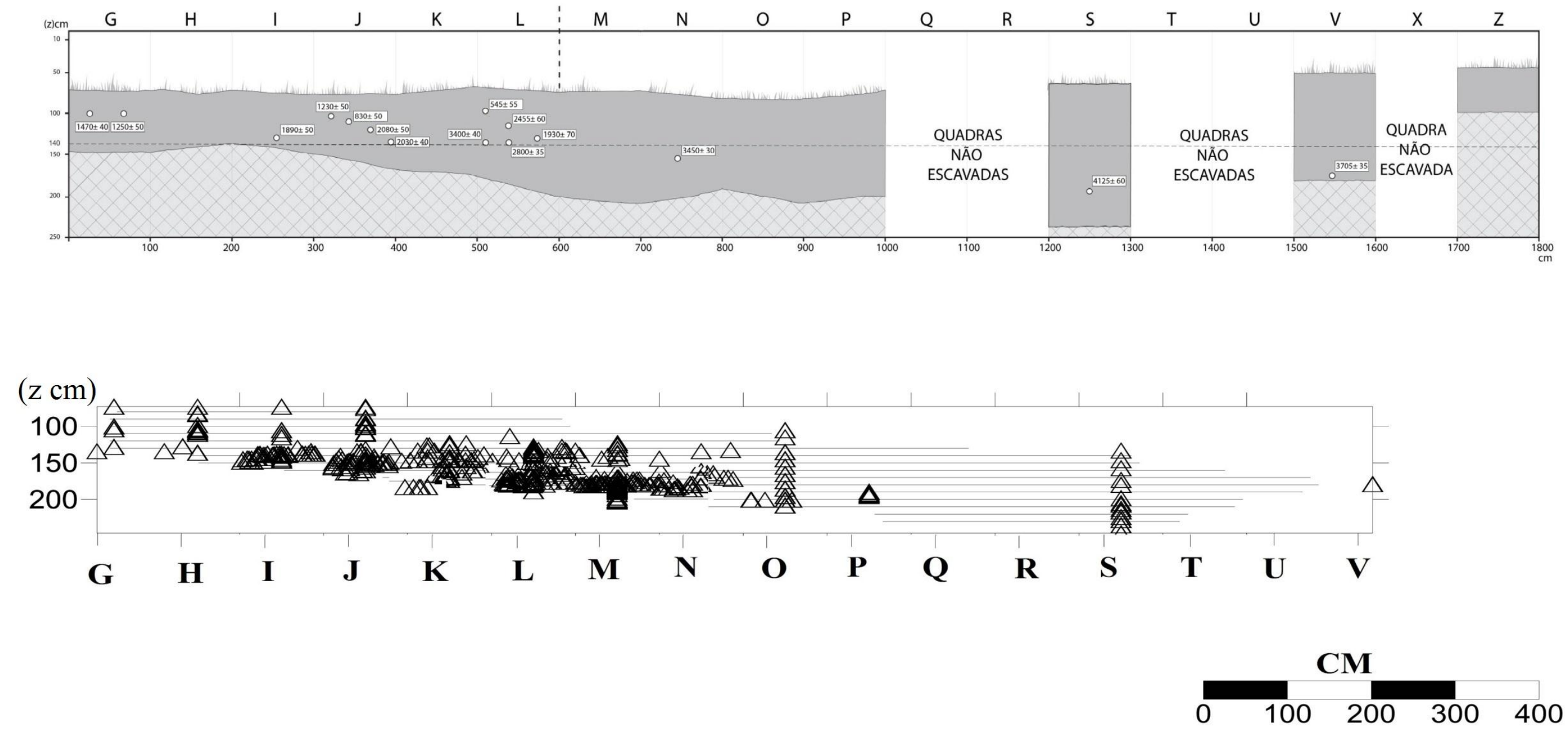


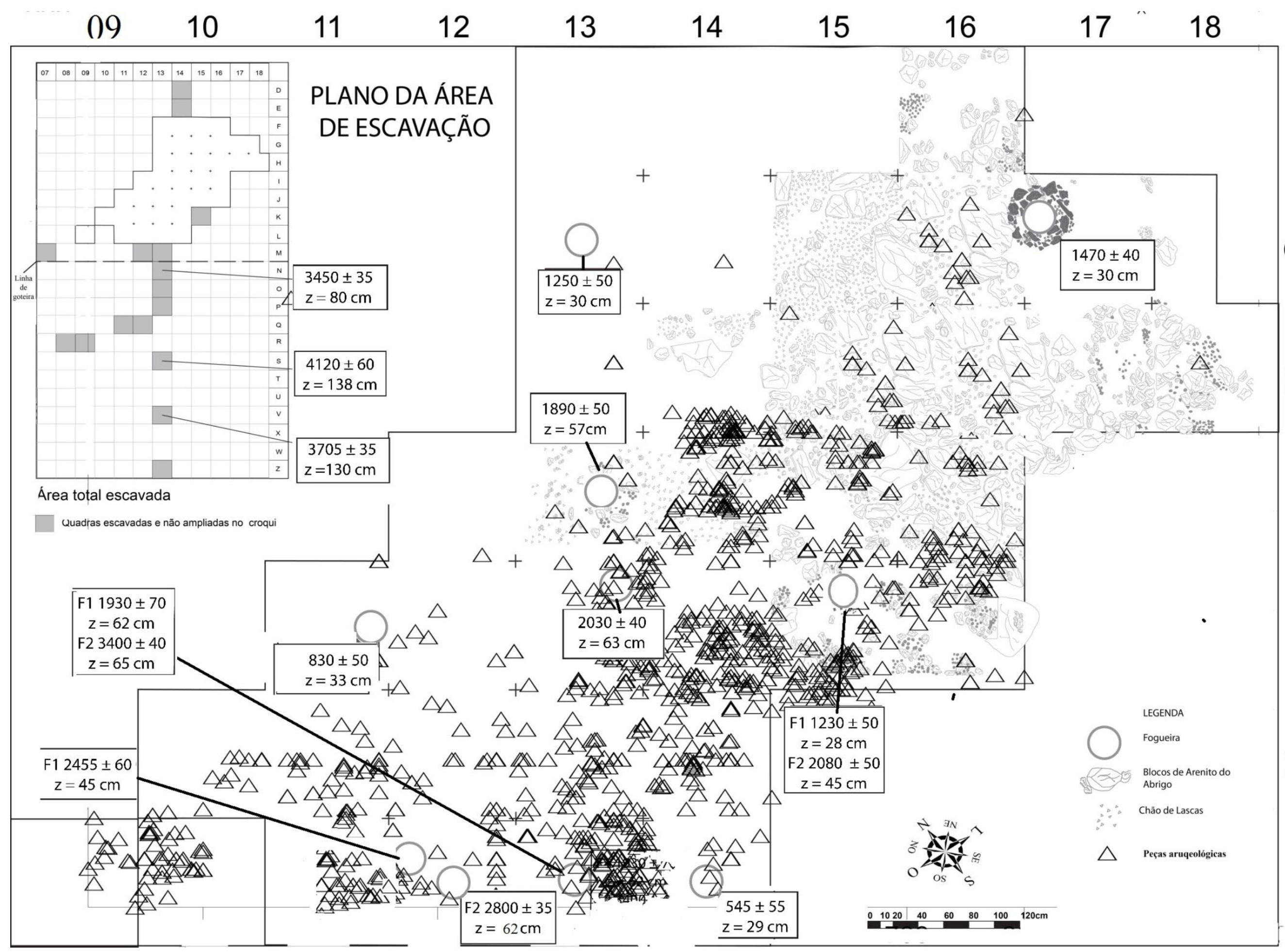


A análise de distribuição vertical dos vestígios arqueológicos, [Figura 22], evidencia o acúmulo de material sobre o embasamento rochoso e favorece a interpretação de que ali se alocaram os vestígios ao longo do tempo, sugerindo processo de deslocamento vertical atuante na estratigrafia do sítio. Todavia, é necessário considerar que nesta análise não há distinção entre matérias-primas quanto ao posicionamento, quantificação, tamanho e peso, sendo necessário, por isso, realizar a discriminação de cada uma delas a fim de observarmos processos específicos de deposição.

Dois comportamentos referentes à deposição de material na área abrigada e não abrigada do sítio são significativos. Nas quadras G, H, I, J, o material arqueológico está presente desde os níveis iniciais até os níveis finais de deposição, mas exibe um processo menos acentuado de deslocamento vertical. Há um processo de rarefação de material nas quadras mais abrigadas $\mathrm{F}, \mathrm{G}$ e um acúmulo de vestígios ao longo dos das quadras I, J.

A partir da quadra L, marca-se a transição para a área externa do abrigo M, N, O, local com maior concentração de material depositado em profundidades abaixo de $150 \mathrm{~cm}$. Além disso, há a possibilidade de um processo de deslocamento vertical atuante em função da inclinação do embasamento rochoso, ou que, nesta área, ocorra um processo de processamento de matérias-primas sobressalente, configurando-se uma área de atividade, ou mesmo, que ambas as ações naturais e culturais sejam concomitantes.

A análise da distribuição horizontal dos vestígios arqueológicos, [Figura 23], estabelece relações explícitas em torno das estruturas de combustão. O setor A possui as estruturas de combustão com o menor número de materiais de qualquer natureza, enquanto no setor B, o material espalha-se por uma área sem estruturas de combustão datadas e por estruturas que perfazem horizonte cronológico em até 2.000 AP. Por fim, o setor C evidencia um intenso processo de deposição de material em um espaço exíguo e sobreposto por estruturas de combustão, apresentando horizontes cronológicos distintos e pequenos agrupamentos de materiais em quadras específicas. 


\subsubsection{A distribuição do sílex}

Foram medidas 485 lascas e fragmentos de lascas que representam a maioria da amostra, apresentando as médias que seguem na [Tabela 1] e foram pesadas 683 peças de sílex. O resultado de análise aponta para a existência de vestígios diminutos em sílex, delgados e leves, suscetíveis de sofrerem um processo de deslocamento no sedimento arenoso.

\begin{tabular}{|c|c|c|c|c|c|}
\hline \multicolumn{6}{|c|}{ Medidas e peso do sillex } \\
\hline & $N$ & Mínimo & Máximo & Média & Desvio Padrão \\
\hline Comprimento (mm) & 485 & 1 & 60 & 17,46 & 13,136 \\
\hline Largura (mm) & 485 & 2 & 75 & 17,59 & 9,751 \\
\hline Espessura (mm) & 485 & 1 & 40 & 9,95 & 6,502 \\
\hline Peso (g) & 683 &, 1 & 95,0 & 2,542 & 7,7121 \\
\hline Válido N (listwise) & 485 & & & & \\
\hline
\end{tabular}

Tabela 1 - Medidas e peso do sílex.

Esta matéria-prima está distribuída na área interna e externa do abrigo e por toda estratigrafia, não havendo isolamento que sugira níveis estratigráficos específicos de deposição. Nota-se, entretanto que acumula-se sobre o embasamento rochoso do abrigo, indício de um processo de aprofundamento das peças na estratigrafia, corroborando a hipótese de que peças diminutas e delgadas possam ter deslizado solo adentro. Entretanto, é plausível também, que esta matéria-prima se reporte a horizontes de deposição mais antigos, sem que fossem deixadas de ser levada e usada ao longo do tempo no abrigo.

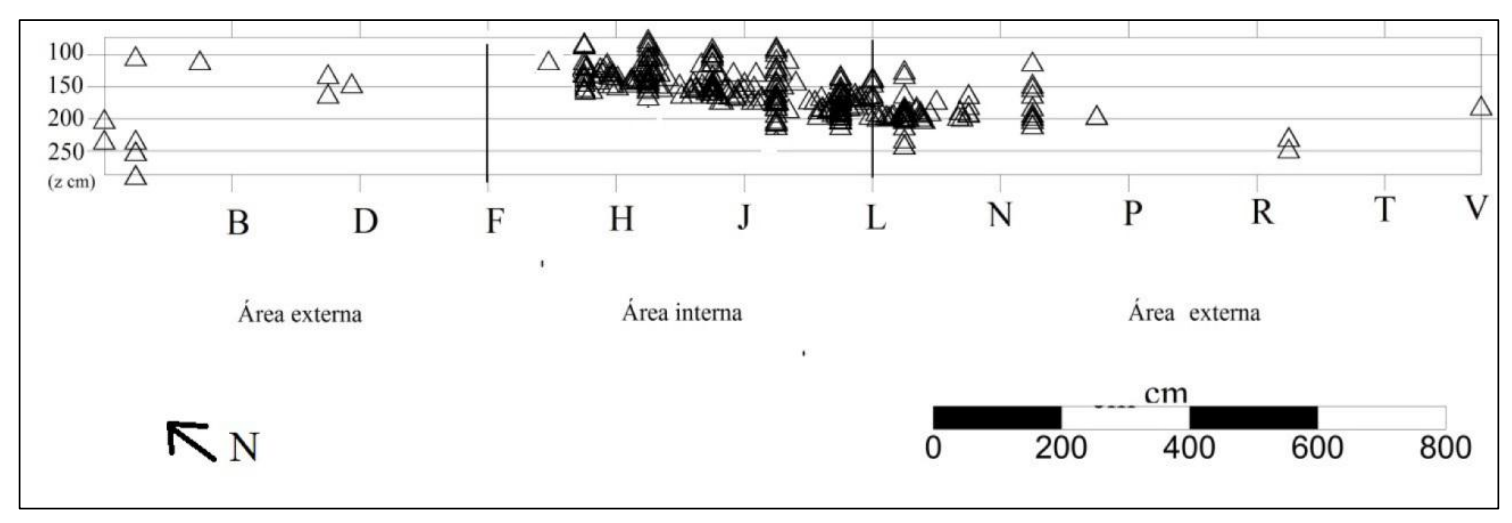

Figura 24 - Distribuição estratigráfica do sílex. 


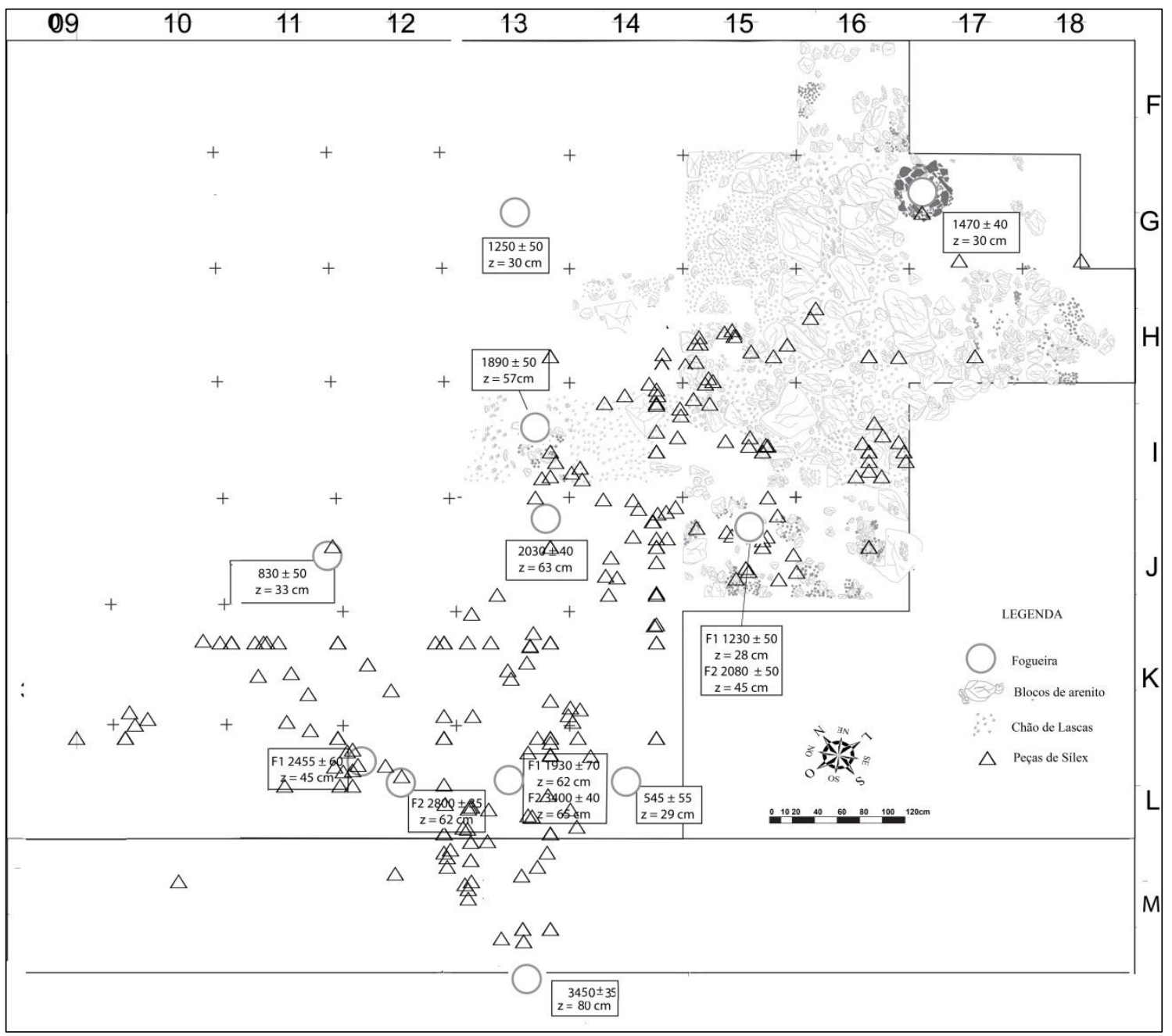

Figura 25 - Distribuição espacial do sílex.

A distribuição espacial do sílex não apresenta uma área de concentração no espaço abrigado ou no espaço externo do sítio. Está mais bem distribuída entre o setor B e o setor $\mathrm{C}$, configurando a possibilidade de um horizonte cronológico relacionado às estruturas de combustão com datações entre 2.000 AP até 3.400 AP. Não obstante, é necessário ter em vista que a ausência deste material entre as estruturas de combustão localizadas na porção mais abrigada com datações mais recentes pode significar também que o material arqueológico ali alocado tenha sido deslocado para setores mais à frente, de modo que qualquer presença nesta área se torne rarefeita e que haja a formação de depósitos secundários entre as estruturas de combustão, fato corrente quando o material é apartado de sua localização de uso (SCHIFFER, 2010, p.30) 
3.4.2 A distribuição do arenito silicificado de fina granulometria

Foram medidas 1010 lascas e fragmentos de lasca que representam a maioria da amostra, apresentando as médias que seguem na [tabela 2] e foram pesados 1215 peças de arenito de fina granulometria. $\mathrm{O}$ resultado de análise é muito similar ao apresentado para o sílex e aponta para a existência de vestígios diminutos, delgados e leves que poderiam se dispersar na estratigrafia.

\begin{tabular}{lrrrrr}
\hline \multicolumn{7}{c}{ Medidas e peso do arenito fino } \\
\hline & $\mathrm{N}$ & Mínimo & Máximo & Média & Desvio Padrão \\
Comprimento (mm) & 1010 & 4 & 120 & 19,63 & 11,344 \\
Largura (mm) & 1010 & 2 & 64 & 16,78 & 9,464 \\
Espessura (mm) & 1010 & 1 & 95 & 6,33 & 7,802 \\
Peso $(\mathrm{g})$ & 1215 &, 1 & 160,0 & 3,238 & 9,0838 \\
Válido N (listwise) & 1010 & & & & \\
\hline
\end{tabular}

Tabela 2 - Medidas e peso do arenito silicificado de fina granulometria.

Foram distribuídas 1215 peças na estratigrafia e área escavada do sítio, de modo que o resultado desta análise é muito similar à estabelecida para o sílex. Evidencia a presença deste material por toda a estratigrafia, não havendo um padrão que sugira a concentração de material em níveis estratigráficos específicos. Nota-se, também, a concentração de material acompanhando o suporte do embasamento rochoso do abrigo. Essa característica pode indicar um processo de aprofundamento das peças na estratigrafia ao longo do tempo, ou, um processo de deposição preferencial na área de contato entre a porção interna e externa do abrigo, nunca deixada de ser utilizada ao longo do tempo, tal qual o padrão apresentado pela matéria-prima sílex.

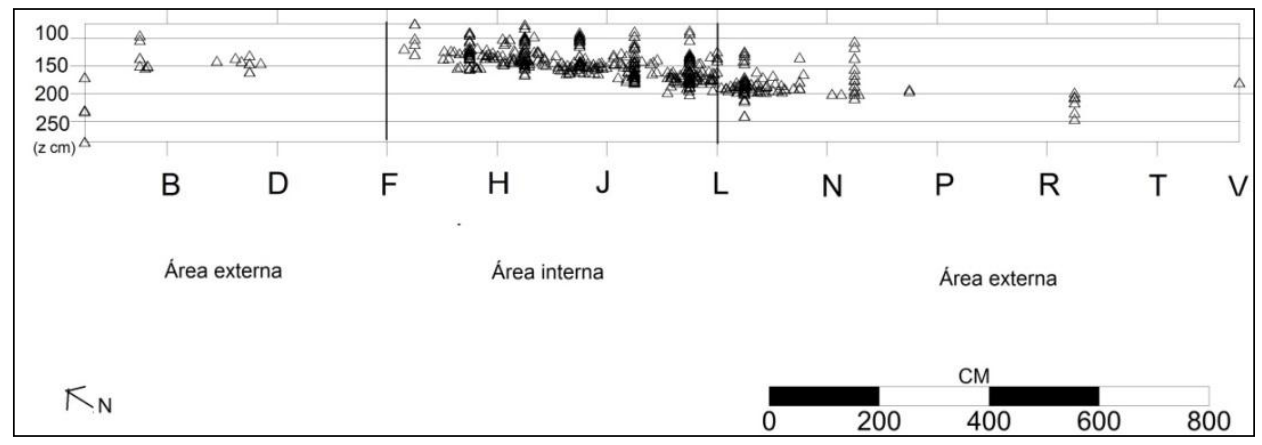

Figura 26 - Distribuição estratigráfica do arenito silicificado de fina granulometria. 


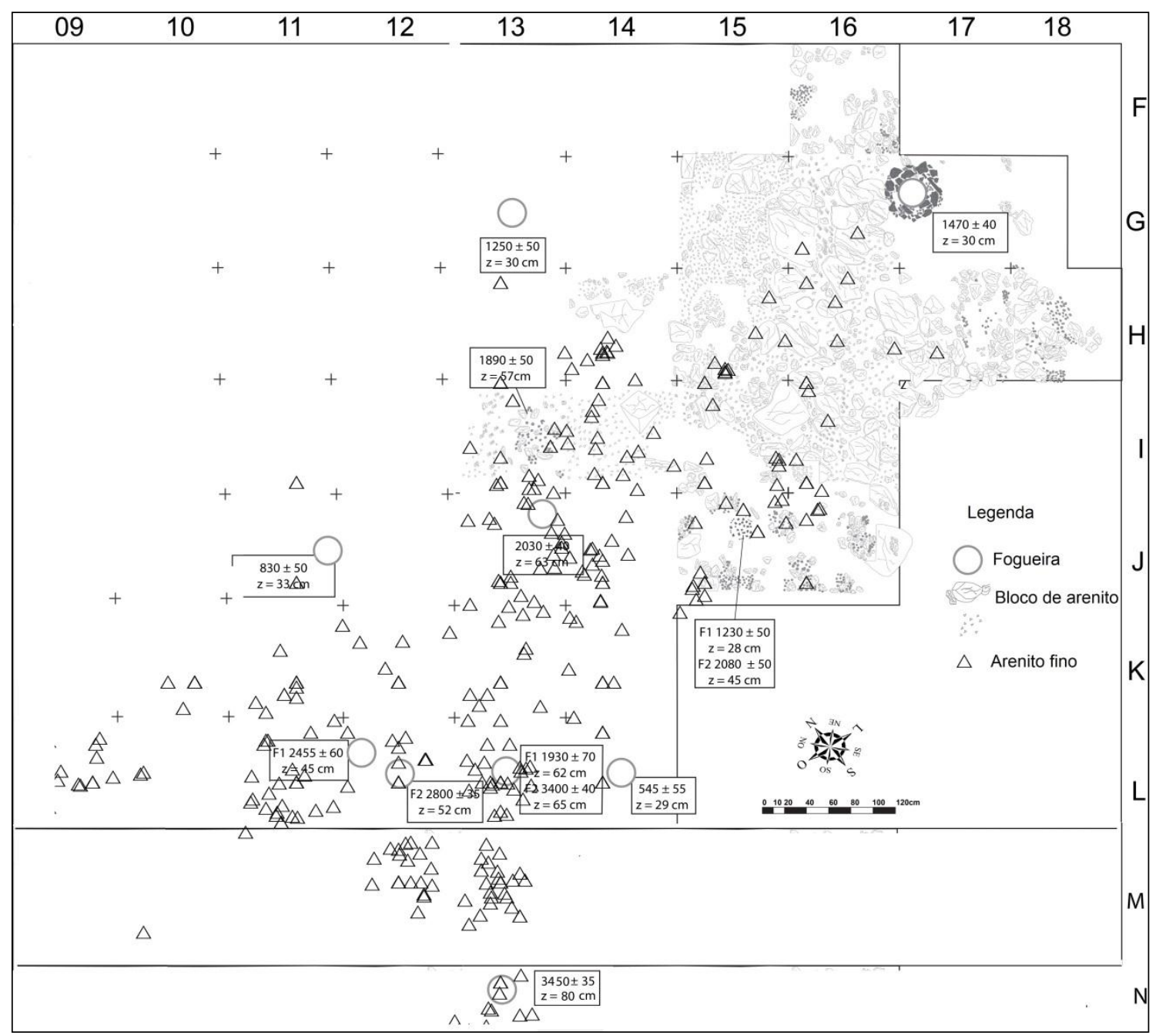

Figura 27 - Distribuição espacial do arenito silicificado de fina granulometria.

A distribuição espacial do arenito de fina granulometria indica que não há uma área de concentração de material no espaço abrigado ou no espaço não abrigado do sítio. Porém que uma boa parcela está alocada na entrada do abrigo, aventando-se a possibilidade de que este material esteja relacionado ao processamento de material nesta área. Amiúde, também se encontra espacialmente distribuído entre o setor B e o setor C, configurando a propensão de um horizonte cronológico de deposição relacionado às estruturas de combustão, que apresentam datações entre 2.000 AP até $3.400 \mathrm{AP}$ e poucos vestígios relacionados às fogueiras mais abrigadas. Não há uma dimensão exata de áreas de atividades, embora alguns indicativos são visíveis, tais quais áreas de concentração de materiais na entrada do abrigo. Não obstante, nota-se que estas áreas potencialmente são aproveitadas para futuras intervenções, de modo que refugos primários ou aqueles descartados em seu local de uso (SCHIFFER, 2010, p.30) são reciclados e transformados. A pergunta que se faz neste caso é 
quais são os critérios para que um objeto possa ser apanhado novamente e que tipos de atividades são desenvolvidas?

\subsubsection{A distribuição do arenito silicificado de grossa granulometria}

Foram medidas 714 lascas e fragmentos de lasca que representam a maioria da amostra, apresentando as médias que seguem na [tabela 3] e foram pesados 917 peças de arenito de fina granulometria. O resultado de análise sugere peças maiores que as encontradas entre o sílex e o arenito silicificado fino, evidenciando maior proporcionalidade entre comprimento e largura, sendo também mais espessas e pesadas.

\begin{tabular}{lrrrrr}
\hline \multicolumn{7}{c}{ Medides e Peso do Arenito Grosso } \\
\hline & $\mathrm{N}$ & \multicolumn{1}{c}{ Mínimo } & \multicolumn{1}{c}{ Máximo } & Média & Desvio Padrão \\
Comprimento (mm) & 714 & 2 & 155 & 29,95 & 18,483 \\
Largura (mm) & 714 & 1 & 110 & 26,62 & 16,898 \\
Espessura (mm) & 714 & 2 & 65 & 10,02 & 7,13 \\
Peso (g) & 917 & 1 & 1712 & 17,88 & 77,016 \\
Valid N (listwise) & 714 & & & & \\
\hline
\end{tabular}

Tabela 3 - Medida e Peso do Arenito silicificado de grossa granulometria.

O resultado de análise sugere a presença deste material por toda a estratigrafia e entre a área abrigada e não abrigada do sítio. Nota-se que este material comporta pontos de concentração na porção de contato entre a área interna e externa do abrigo. Acrescenta-se que boa parte aloca-se sobre o embasamento rochoso, apresentando um padrão distributivo muito similar ao encontrado nas matérias-primas anteriormente analisadas, independente dos seus respectivos tamanhos e pesos.

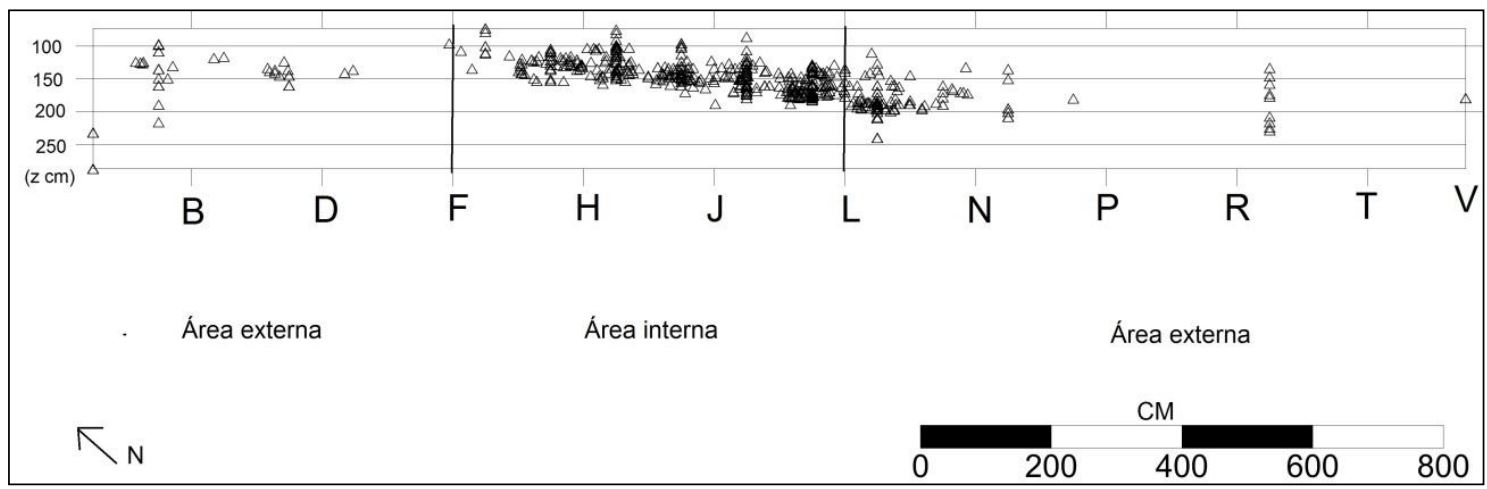

Figura 28 - Distribuição estratigráfica do arenito silicificado de grossa granulometria. 


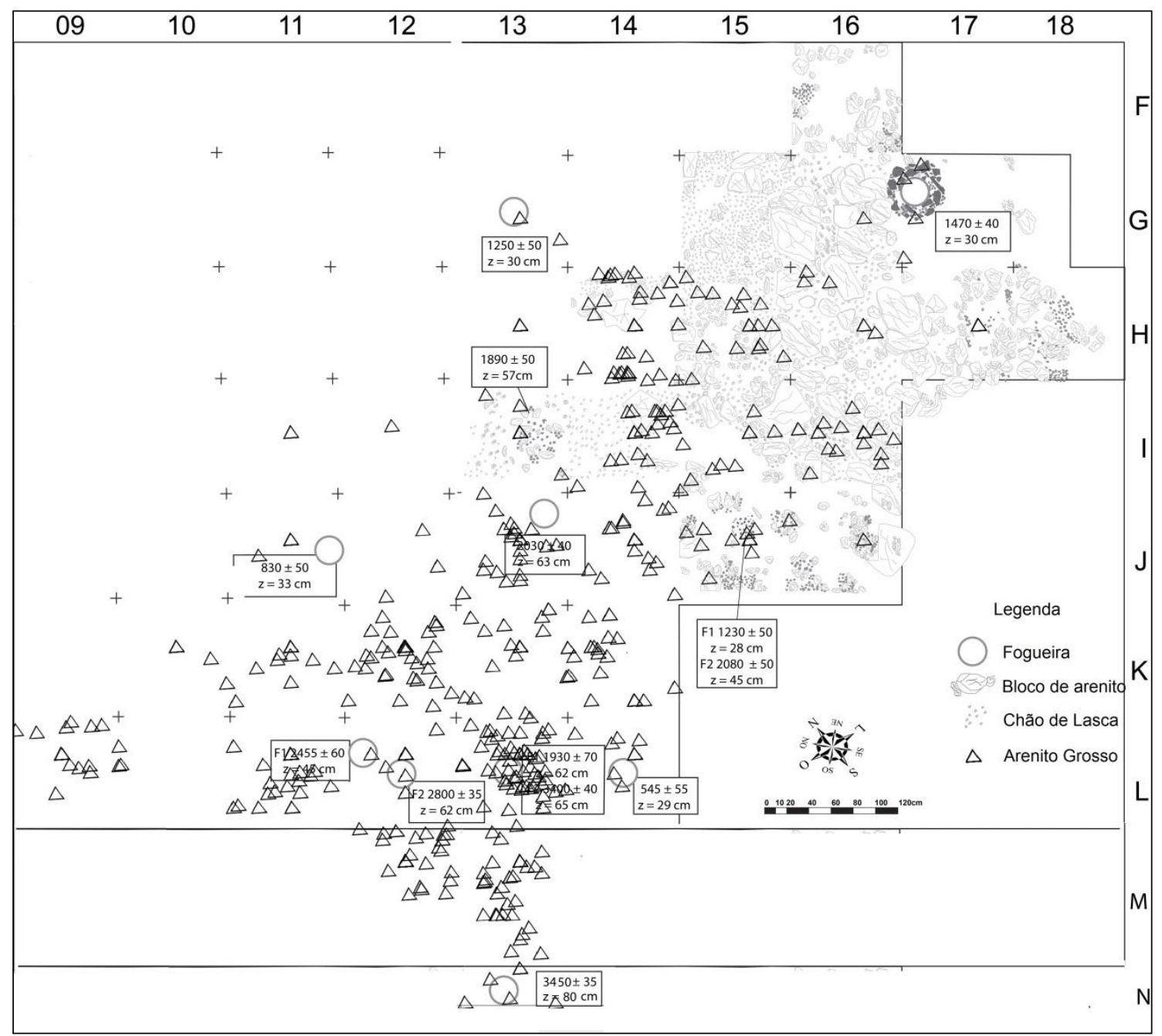

Figura 29 - Distribuição espacial do arenito silicificado de grossa granulometria.

A distribuição espacial do arenito de grossa granulometria indica uma área de maior concentração de material na área de contato entre o espaço abrigado e não abrigado do sítio, sobre as fogueiras sobrepostas com horizontes cronológicos distintos que variam entre $545+-$ 55 até 3.400 +-35 AP, de maneira que este material expande-se em direção à área externa do sítio, configurando um local de acúmulo desta matéria-prima lítica. Não obstante, deve-se ressaltar que há grande dispersão também na área interna do sítio, configurando um padrão comum às matérias-primas sílex e arenito silicificado fino. 
3.4.4 A distribuição do óxido de ferro

Foram medidas 341 lascas e fragmentos de lasca que apresentam as médias que seguem na [tabela 4] e foram pesadas 341 peças. O resultado de análise sugere peças maiores e maior proporcionalidade entre comprimento e largura, destarte, são relativamente mais pesadas em relação a outras matérias-primas analisadas.

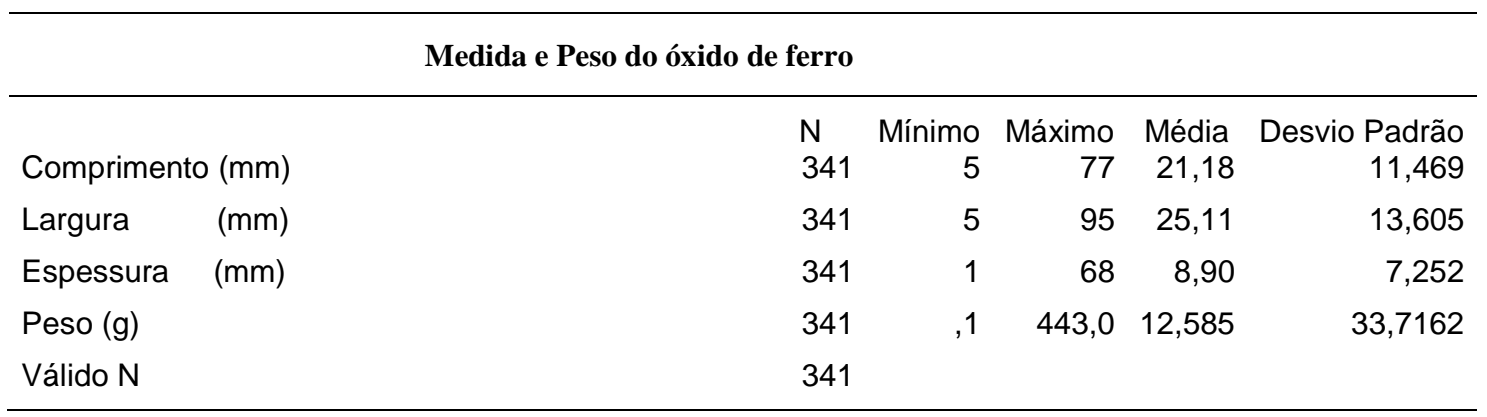

Tabela 4 - Medida e Peso do óxido de ferro.

O óxido de ferro também não apresenta concentrações específicas na área interna ou externa do abrigo, estando distribuído por toda a estratigrafia, embora haja alguns pontos de concentração em quadras entre os metros $\mathrm{H}, \mathrm{J}, \mathrm{L}$ na porção abrigada e M, na área de entrada. O padrão distributivo é muito similar ao apresentado até o momento para as matérias-primas anteriormente analisadas.

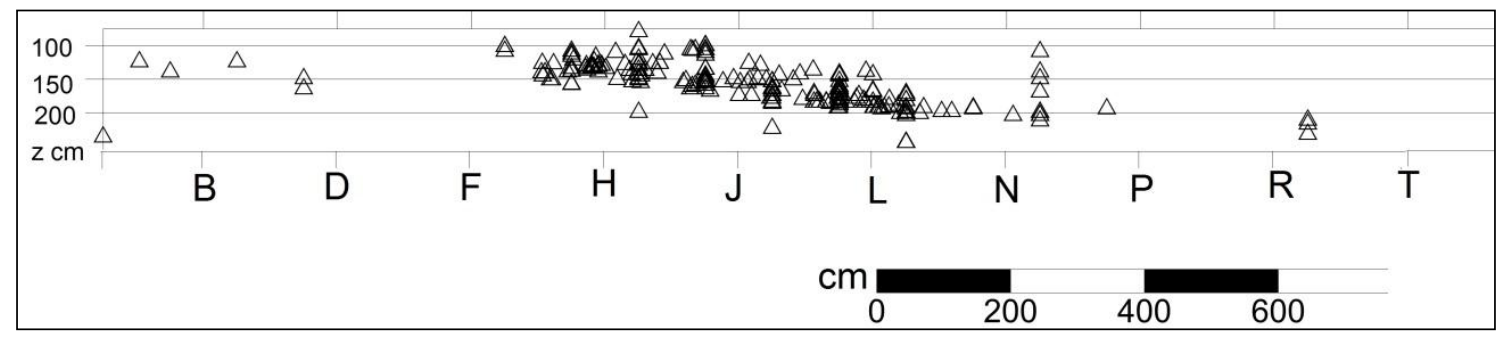

Figura 30 - Distribuição estratigráfica do óxido de ferro. 


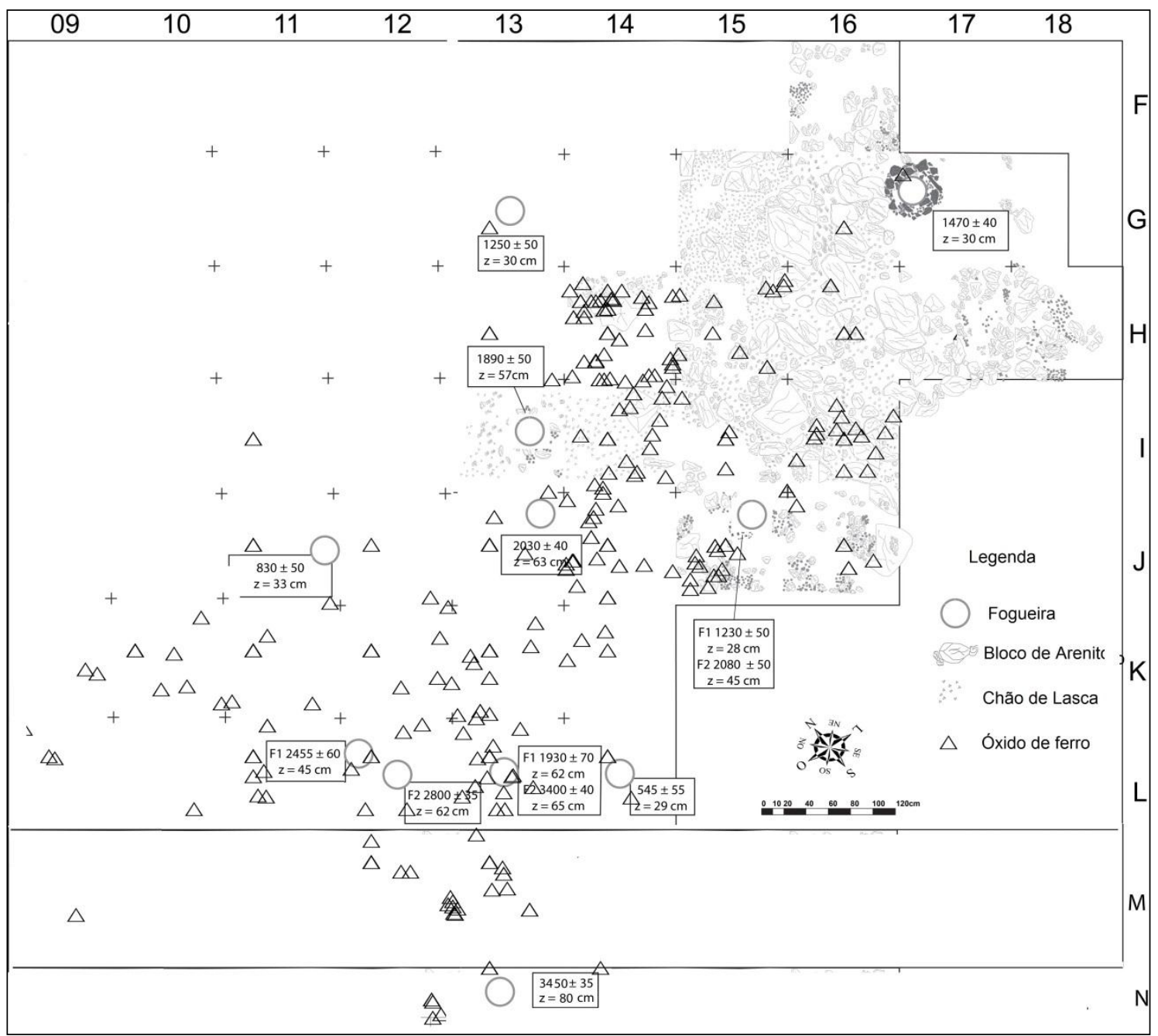

Figura 31 - Distribuição espacial do óxido de ferro.

A distribuição espacial do óxido de ferro sugere uma concentração um pouco mais evidente na área mais abrigada do sítio, com o horizonte cronológico associado em até 2.000 $\mathrm{AP}$, embora poucos materiais estejam em conexão com a área externa do sítio. Consoante à condição especial deste tipo de vestígio arqueológico associado à manifestação artística, distribuímos na estratigrafia e na área do sítio os vestígios que apresentam marcas de uso e potenciais conexões entre as paredes e o solo de ocupação. Embora os resultados de análise espacial apontem para certa concentração desta material em setores mais internos do abrigo com horizontes estratigráficos datados em até $2.000 \mathrm{AP}$, sugere-se que a atividade de pintura é ininterrupta ao longo do tempo conforme a análise estratigráfica indica e que potencialmente este material seja remanejado dentro da área do abrigo, de modo que pode haver um deslocamento para setores mais abrigados. 


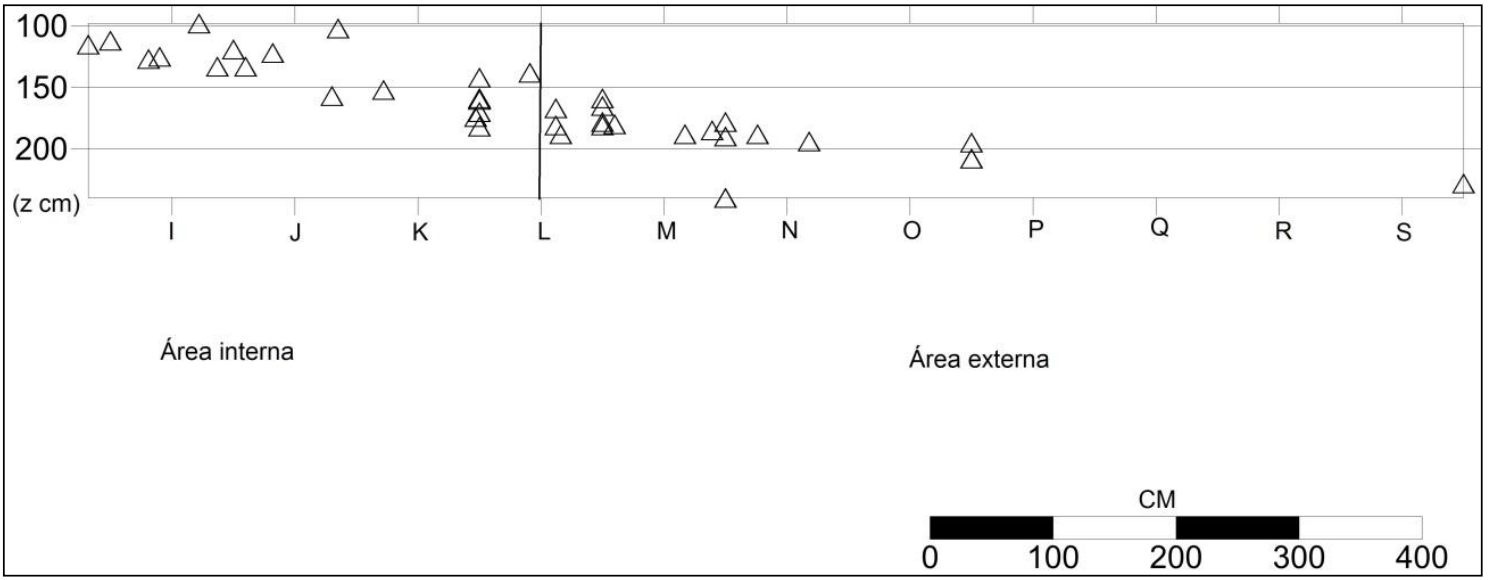

Figura 32 - Distribuição estratigráfica do óxido de ferro com marca de uso.

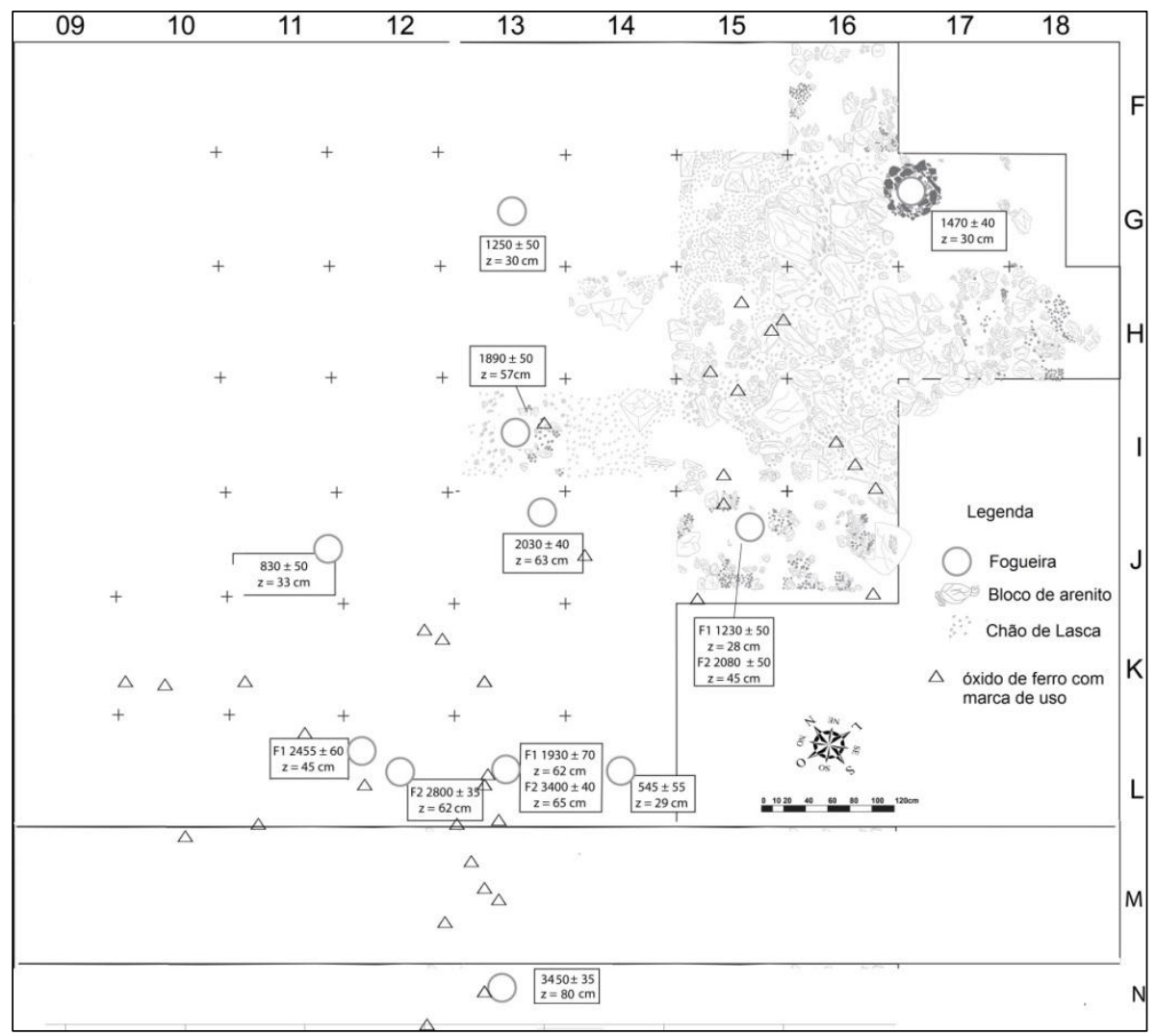

Figura 33 - Distribuição espacial do óxido de ferro com marca de uso. 


\subsubsection{A distribuição da rocha verde}

Foram medidas 95 lascas e fragmentos de lasca que apresentam as médias que seguem na [tabela 5] e foram pesadas 209 peças de rocha verde. O resultado de análise sugere peças maiores e maior proporcionalidade entre comprimento e largura, sendo também levemente mais espessas e pesadas que o sílex e o arenito de fina granulometria e menos pesadas e espessas que o arenito de grossa granulometria.

\begin{tabular}{|c|c|c|c|c|c|c|}
\hline Me & & $\mathbf{N}$ & Mínimo & Máximo & Média & Desvio Padrão \\
\hline \multicolumn{2}{|c|}{ Comprimento (mm) } & 95 & 4 & 125 & 31,41 & 20,669 \\
\hline Largura & $(\mathrm{mm})$ & 95 & 7 & 115 & 30,96 & 19,745 \\
\hline Espessura & $(\mathrm{mm})$ & 95 & 2 & 30 & 7,93 & 5,545 \\
\hline Peso & (g) & 209 & 1 & 195 & 10,61 & 24,936 \\
\hline \multicolumn{2}{|c|}{ Válido N (listwise) } & 95 & & & & \\
\hline \multicolumn{2}{|c|}{ Válido N (listwise) } & 209 & & & & \\
\hline
\end{tabular}

Tabela 5 - Medida e peso da Rocha Verde.

Os resultados de análise apontam que a maioria das peças se concentram em níveis estratigráficos localizados em até $150 \mathrm{~cm}$ de profundidade, em quadras predominantemente até o metro $\mathrm{J}$, sofrendo rarefação em direção à área externa. É necessário considerar que a distribuição desta matéria-prima é condizente com a localização e profundidade da camada arenosa A, apresentando condições para a afirmação de que é plausível a possibilidade de um horizonte cronológico estratigráfico de deposição em até $150 \mathrm{~cm}$.

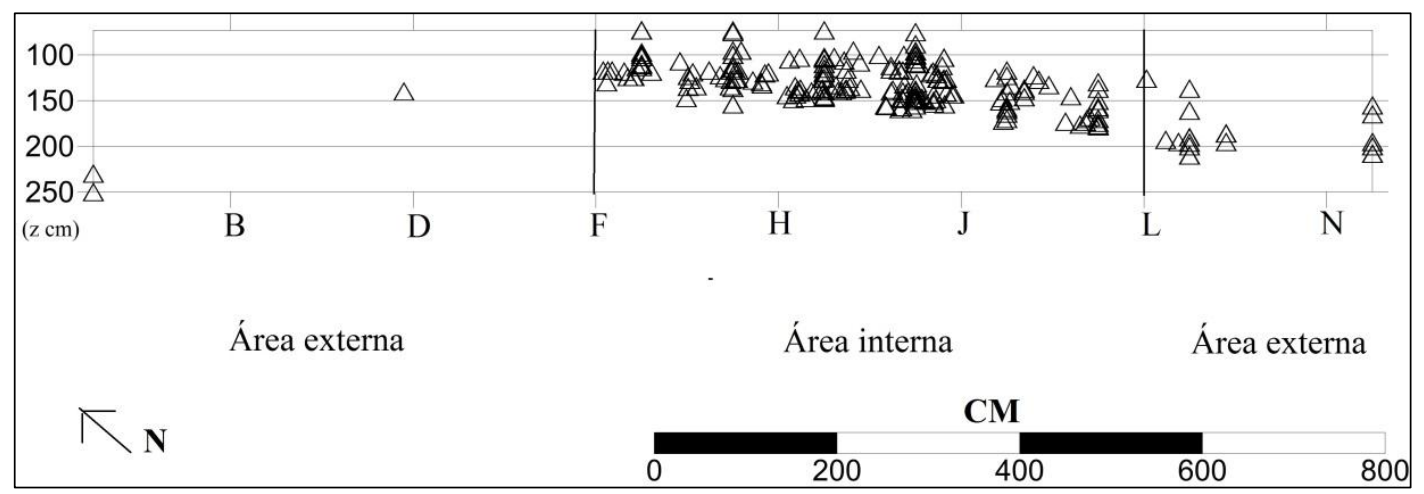

Figura 34 - Distribuição estratigráfica da rocha verde. 


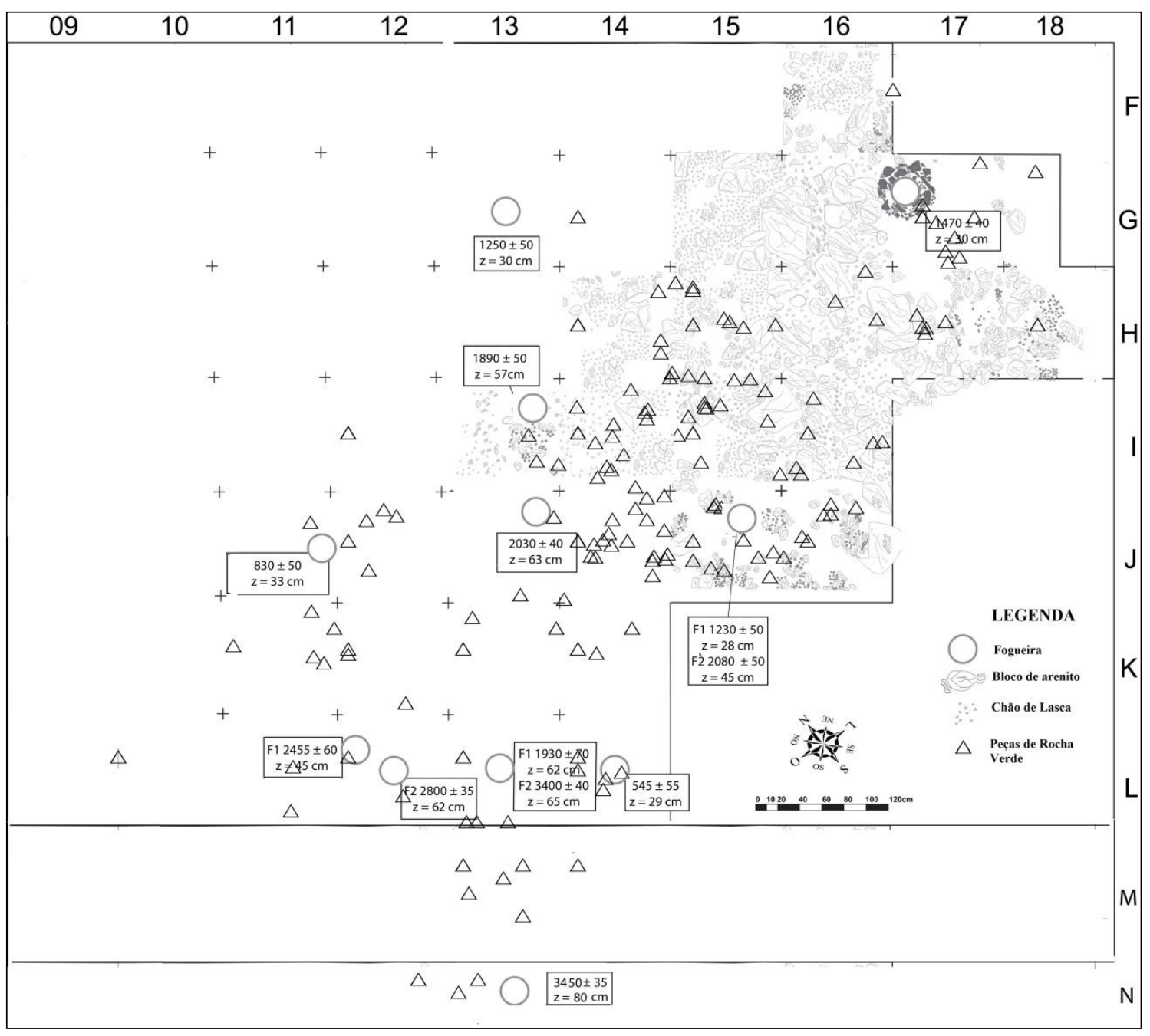

Figura 35 - Distribuição espacial da Rocha Verde.

A distribuição espacial da rocha verde indica uma área de maior concentração de material no espaço mais abrigado do sítio sobre e entre as fogueiras do setor $\mathrm{B}$, denotando um possível horizonte de deposição relacionado até 2.000 AP. Poucos são os vestígios presentes em metros contidos nas áreas menos abrigadas. Aponta-se também para um discreto processo de deslocamento vertical, de modo que a distribuição desta matéria-prima na estratigrafia e na área escavada do sítio estão melhor definidas e mantém certa relação espacial e estratigráfica preservadas no espaço abrigado. Este comportamento é inverso ao observado em outras matérias-primas alocadas na mesma área que apresentam padrão considerado dispersivo e comunicante com a área interna/externa do sítio. Tendo em vista esta evidencia, a quais fatores poderiam estar relacionado este comportamento? É necessário considerar a exploração de sua ocorrência diferencial dentro e entre as matérias-primas examinadas. 


\subsubsection{A distribuição da cerâmica}

Foram medidos e pesados 26 fragmentos cerâmicos que apresentam as medidas e peso contidos na [tabela 6]. Em sua maioria os fragmentos são quadráticos, espessos e mais pesados que a grande parcela do material lítico.

\begin{tabular}{lrrrrr}
\hline Medidas & N & \multicolumn{1}{c}{ Mínimo } & Máximo & Média & Desvio Padrão \\
\hline Comprimento (mm) & 26 & 15 & 65 & 31,38 & 11,990 \\
Largura (mm) & 26 & 18 & 86 & 42,92 & 17,295 \\
Espessura (mm) & 26 & 5 & 12 & 9,15 & 1,666 \\
Peso (g) & 26 & 2 & 69 & 17,42 & 19,397 \\
Válido N (listwise) & 26 & & & & \\
\hline
\end{tabular}

Tabela 6 - Medida e peso dos vestígios cerâmicos.

A distribuição estratigráfica dos fragmentos cerâmicos para a maioria das peças exibe nível de deposição em até $150 \mathrm{~cm}$ e duas áreas de concentração nas quadras I e L. A concentração na quadra I perfaz níveis estratigráficos situados entre $90 \mathrm{~cm}$ a $120 \mathrm{~cm}$, enquanto na quadra L, níveis estratigráficos entre $130 \mathrm{~cm}$ até $172 \mathrm{~cm}$. É possível que os fragmentos localizados na quadra L, situados abaixo de $150 \mathrm{~cm}$, relacionem-se a um processo de deslocamento vertical e não representem níveis deposicionais tão profundos, haja vista a compatibilidade na distribuição dos fragmentos cerâmicos e da rocha verde, ambos com a maior parcela de material alocado em até $150 \mathrm{~cm}$.

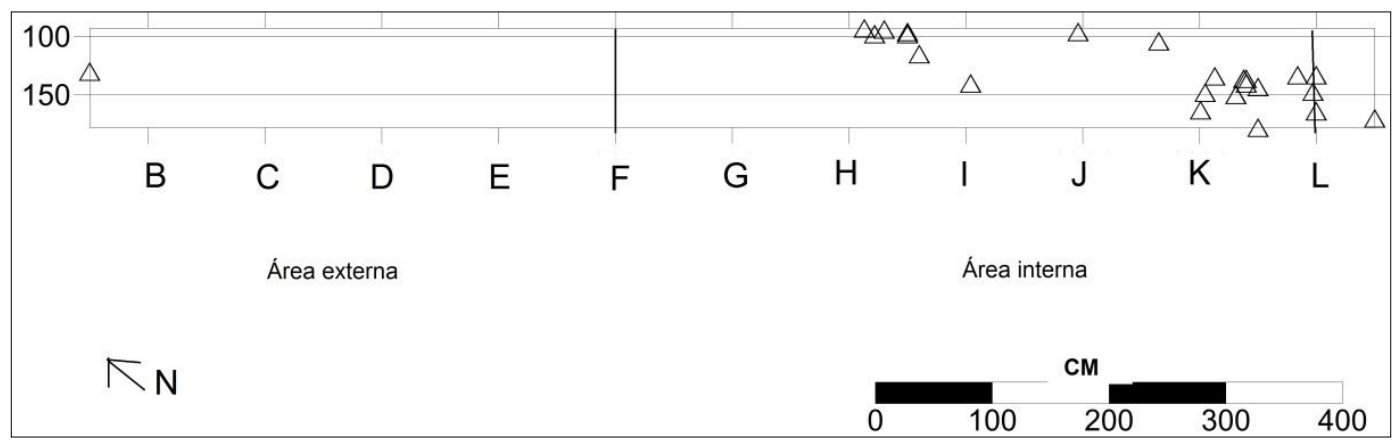

Figura 36 - Distribuição estratigráfica dos fragmentos cerâmicos. 


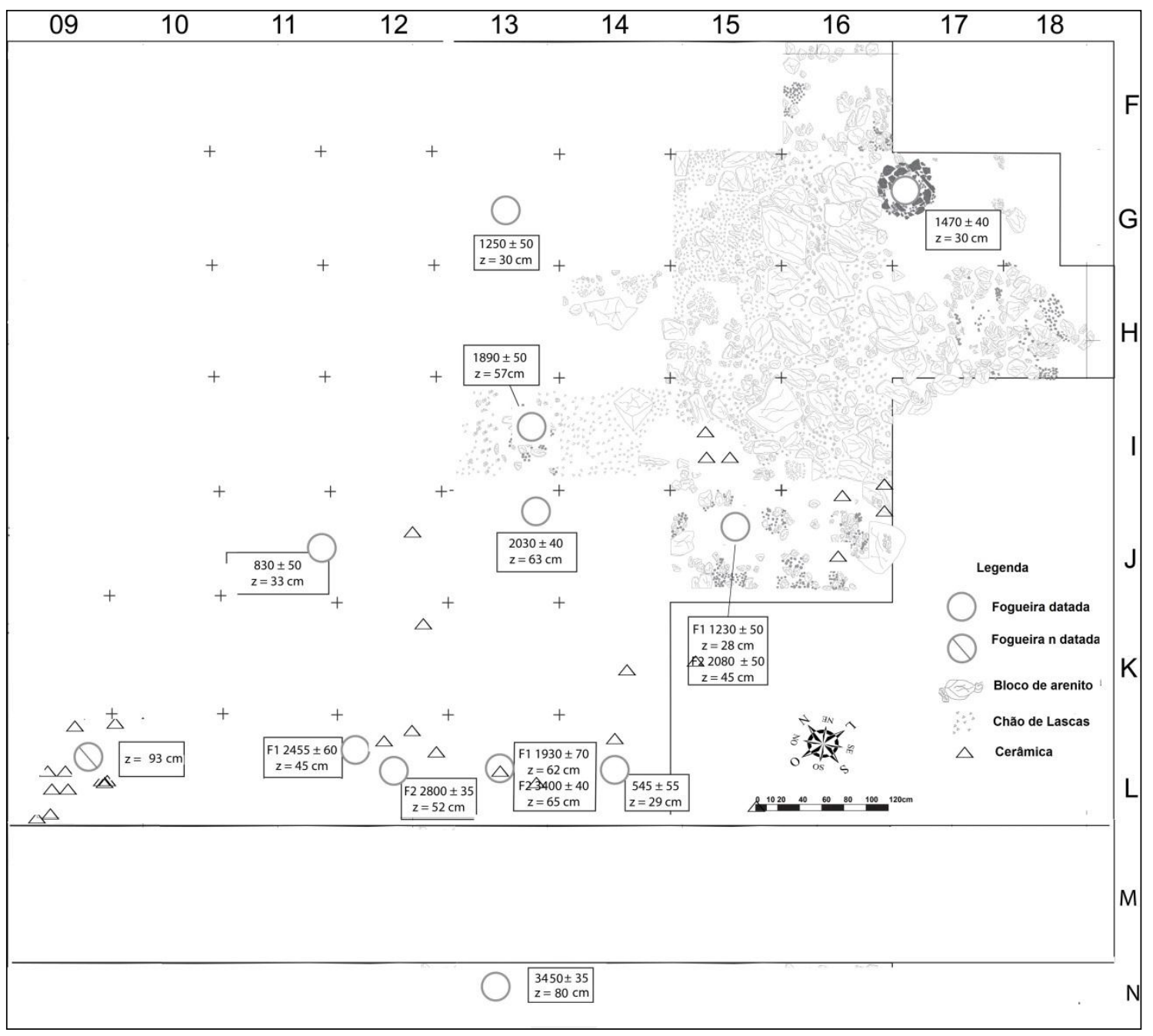

Figura 37 - Distribuição espacial dos fragmentos cerâmicos.

Os fragmentos cerâmicos estão situados em torno de estruturas de combustão com horizontes cronológicos situados entre 1.200 AP até 2.800 AP. Estas estruturas são sobrepostas, indicando que antigas áreas de fogueiras podem ter sido reocupadas por grupos que faziam uso de cerâmica em tempos mais recentes. Especialmente, nota-se a maior concentração de material cerâmico na quadra 9L, em que não há uma datação radiométrica estabelecida para uma fogueira profunda. É digno de nota que poucos fragmentos estão abaixo de níveis estratigráficos anteriores à $150 \mathrm{~cm}$. A principal diferença da deposição da rocha verde e da cerâmica em relação as outras matérias-primas é a possibilidade de isolar clusters compostos pelo mesmo material, o qual torna mais aparente uma área de atividade. Não obstante, deve-se considerar que as demais matérias-primas são elementos da atividade que envolvem processos culturais e naturais que devem ser identificáveis por sua mútua 
correlação entre os múltiplos localizações de refugos primários e secundários (SCHIFFER, 2010, p.68).

\section{5 - REMONTAGENS}

Realizar a análise de remontagens do material arqueológico em torno das coordenadas $\mathrm{x}, \mathrm{y}$ e z é um indicativo forte de um processo de concentração, dispersão ou movimentação de peças. A respeito deste tipo de análise, é necessário dizer que um minucioso trabalho junto à coleção lítica foi exigido para obtermos as remontagens, porém poucas foram obtidas [tabela 7]. Algumas das características do registro arqueológico podem corroborar a ocorrência de poucas remontagens em primeiro grau em Abrigos Vermelhos:

1. As texturas das rochas sofrem variações de silicificação, cor e granulometria, além de alterações devido a contatos abruptos entre partes extremamente bem silicificadas e outras não, formando um verdadeiro mosaico de cores e texturas (SILVA, 2005, p.43);

2. Tecnologicamente, há a presença de apenas algumas etapas de lascamento, indicando que a debitagem e manutenção de ferramentas está presente no sítio, mas os núcleos propriamente ditos estão ausentes;

3. Um alto índice de alteração da superfície dos fragmentos causado por ação térmica, alterando as características estruturais das rochas, que mudam de coloração.

Os resultados de análise das remontagens estão expressos a seguir e apontam em direções importantes para um processo de deslocamento, indicando a possibilidade de que o material arqueológico tenha sofrido um processo de aprofundamento no solo e dispersão espacial na área abrigada. Não obstante, embora a movimentação espacial ocorra, sugere-se que o material esteja alocado em torno das estruturas de combustão e de certa forma, quase completamente associado ao espaço interno do sítio. Enquanto que, a movimentação vertical parece mais acirrada, de modo que matérias-primas líticas como o sílex, o arenito silicificado fino e o arenito silicificado grosso não se detêm em níveis de deposição específicos, conforme se verifica na análise de distribuição destas matérias-primas, mas, no entanto, o posicionamento das remontagens pode variável consideravelmente, de modo que peças podem se deslocar $84 \mathrm{~cm}$ ou praticamente estar posicionadas no mesmo local [Tabela 7]. 


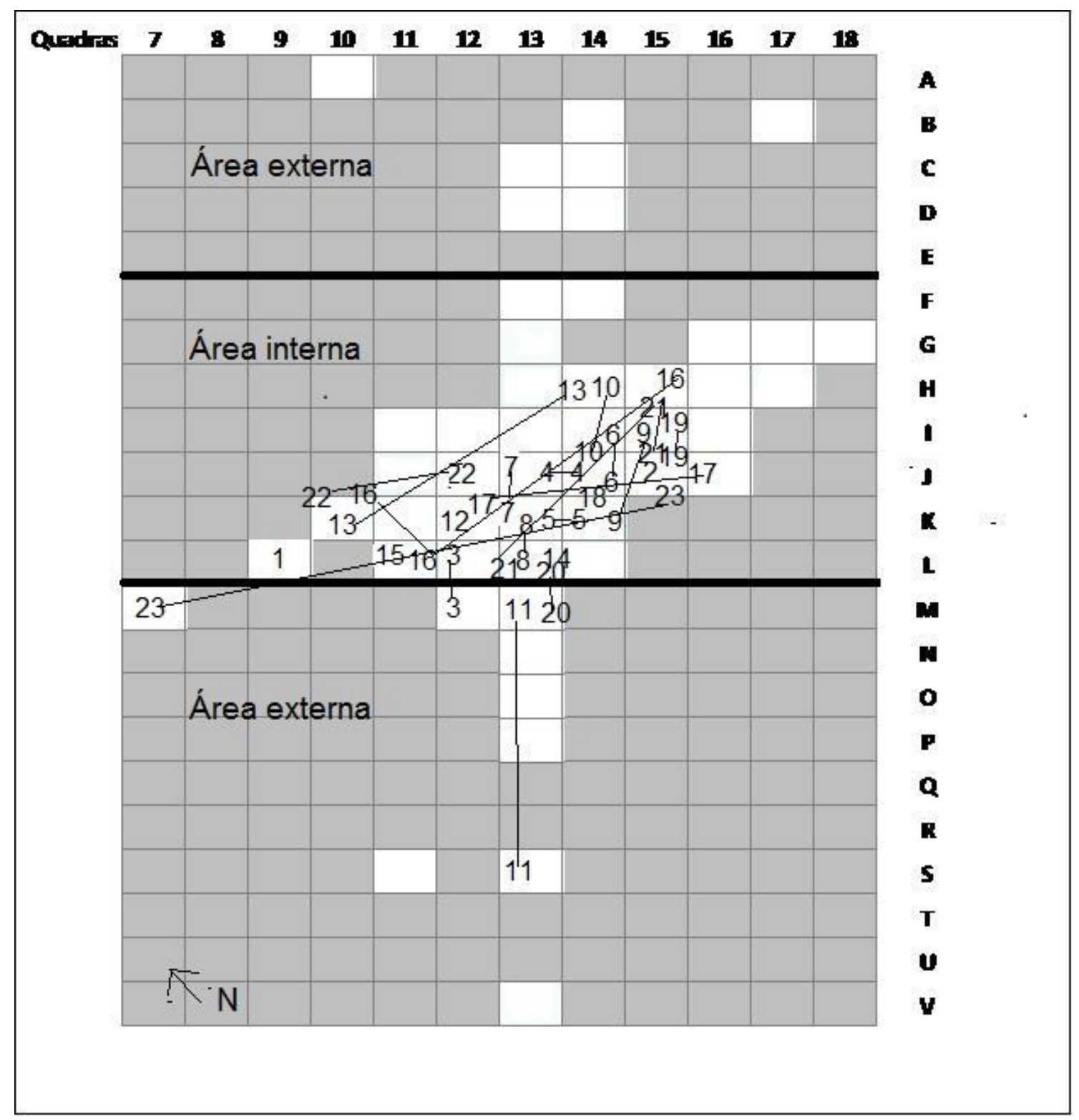

Figura 38 - As remontagens em perspectiva espacial. 


\begin{tabular}{|c|c|c|c|c|c|c|}
\hline Remontagem & Números & material & Quadras & $\mathrm{z}(\mathrm{cm})$ & Deslocamento vertical (cm) & Deslocamento Horizontal (m) \\
\hline & $13900-3873$ & cerâmica & $9 \mathrm{~L}$ & $136-143$ & 6 & 0 \\
\hline & 2 1011-1039 & arenito silificado grosso & $15 \mathrm{~J}$ & $126-135$ & 9 & 0 \\
\hline & 3 3579-3675 & arenito silificado grosso & $12 \mathrm{~L}-12 \mathrm{M}$ & $146-186$ & 40 & 1 \\
\hline & $4782-1348$ & arenito silificado fino & $13 \mathrm{~J}-14 \mathrm{~J}$ & $144-150$ & 6 & 1 \\
\hline & 5 2689-4102 & arenito silificado grosso & $13 \mathrm{k}-14 \mathrm{~K}$ & $126-134$ & 8 & 1 \\
\hline & $6489-498$ & arenito silificado grosso & $14 \mathrm{I}-14 \mathrm{~J}$ & $103-122$ & 19 & 1 \\
\hline & $7438-2752$ & arenito silificado grosso & $13 \mathrm{~J}-13 \mathrm{~K}$ & $142-144$ & 2 & 1 \\
\hline & $82681-2724$ & arenito silificado grosso & $13 \mathrm{~L}-13 \mathrm{~K}$ & $126-128$ & 2 & 1 \\
\hline & 9 701-3542 & arenito silificado grosso & $14 \mathrm{~K}-15 \mathrm{I}$ & $102-133$ & 31 & 1 \\
\hline & $10972-1215$ & sílex & $14 \mathrm{H}-14 \mathrm{~J}$ & $125-141$ & 26 & 2 \\
\hline & $112932-3250$ & arenito silificado grosso & $13 M-13 S$ & $144-228$ & 84 & 6 \\
\hline & $123762-3763$ & arenito silificado grosso & $12 \mathrm{~K}$ & 151 & 0 & 0 \\
\hline & 13 1895-4234 & sílex & $14 \mathrm{H}-10 \mathrm{~K}$ & $134-170$ & 36 & 5 \\
\hline & $145528-5541$ & sílex & $13 \mathrm{~L}$ & 186 & 0 & 0 \\
\hline & 15 5737-6341 & sílex & $11 \mathrm{~L}$ & 189-195 & 6 & 0 \\
\hline & 16 1232-3551-1432-3558 & sílex & $10 \mathrm{~K}, 15 \mathrm{H}, 11 \mathrm{~L}, 14 \mathrm{~J}$ & $116,149,151,152$ & 36 & 8 \\
\hline & $17736-2678$ & sílex & $12 \mathrm{~K}-16 \mathrm{~J}$ & $112-140$ & 38 & 1 \\
\hline & 18 1168-1169 & rocha verde & $14 \mathrm{~J}$ & 143 & 0 & 0 \\
\hline & $19507-578$ & rocha verde & $15 \mathrm{I}-15 \mathrm{~J}$ & $103-110$ & 7 & 1 \\
\hline & $204512-6354$ & óxido de ferro & $13 \mathrm{~L}-13 \mathrm{M}$ & 178-188 & 10 & 1 \\
\hline & $216322-745-1324$ & quartzo & $13 \mathrm{~L}, 15 \mathrm{I}, 15 \mathrm{~J}$ & $141,148,148$ & 7 & 6 \\
\hline & 22 3538-2709 & arenito silicificado fino & $10 \mathrm{k}-12 \mathrm{~J}$ & $140-150$ & 10 & 1 \\
\hline & 23 4963-1325 & arenito grosso & $7 \mathrm{M}-15 \mathrm{~J}$ & $142-210$ & 68 & 9 \\
\hline Média & & & & & 19,60869565 & 2,043478261 \\
\hline
\end{tabular}

Tabela 7 - Lista com as remontagens.

Os resultados indicam que a média de deslocamento vertical de peças é de $19 \mathrm{~cm}$ de aprofundamento no solo e a movimentação horizontal apresenta a média de $2 \mathrm{~m}$. O peso e o tamanho das peças parecem interferir na intensidade de deslocamento vertical das matériasprimas sílex e arenito silicificado fino, cujo peso leve e a espessura delgada propiciam o fenômeno de escorregamento. Também este processo se verifica no arenito silicificado grosso, de peças mais pesadas e espessas, aspecto menos esperado para esta análise. Além disso, as matérias-primas óxido de ferro e rocha verde, e também a cerâmica, parecem se movimentar de modo mais discreto e contido na estratigrafia, demonstrando um processo menos evidente de deslizamento.

Sobre as remontagens, a conclusão é que embora haja um processo de dispersão das matérias-primas, elas tendem a contrariar esta afirmação, de modo que os resultados de análise indicam que a maioria das peças estão alocadas em até $150 \mathrm{~cm}$ [Figura 34] e a posição de cada remontagem pode ser vista no APÊNDICE 2. Reforça-se com isto o argumento que embora haja processos de formação atuantes, de modo que as matérias-primas sílex, arenito grosso e fino e óxido de ferro se distribuem por toda a estratigrafia, as remontagens, além da rocha verde e cerâmica, indicam a demarcação de dois horizontes cronoestrigráficos. $\mathrm{O}$ primeiro situado em até 2.000 AP que comporta a rocha verde e a cerâmica o segundo que perpassa este horizonte, sendo composto pelo sílex, pelo arenito silicificado grosso e fino e pelo óxido de ferro, podendo atingir datações de até 3.400 AP no limiar da área interna e externa do abrigo. 


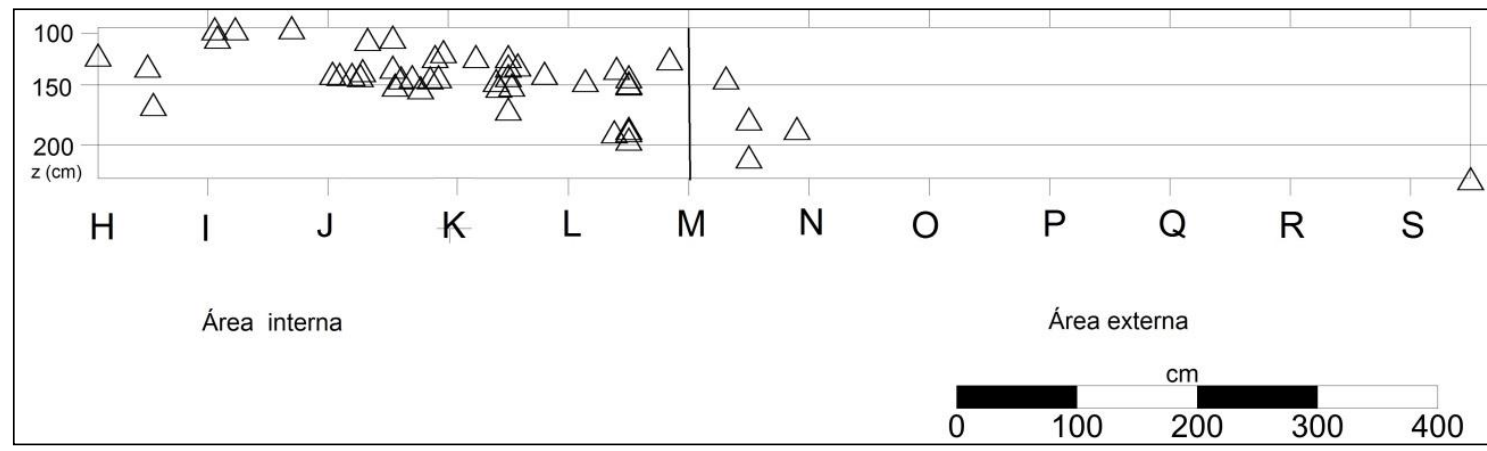

Figura 39 - As remontagens em perspectiva estratigráfica.

Consoante a esta análise é possível inferir que a área interna do abrigo aponta para o acúmulo de diferentes materiais sobre os mesmos pontos ao longo do tempo, para o uso das mesmas áreas de atividades e para um processo de movimentação vertical e espacial dentro do abrigo com caráter variável, de modo que, exceto para a rocha verde e a cerâmica, não foi possível delimitar cluster de materiais. Deste modo, observamos que o registro arqueológico é dinâmico e que as análises efetuadas servem de estratégias para responder a questões sobre o uso da cultura material feita no passado quanto a questões específicas descritivas, de modo a ter em vista quais são os determinantes da variabilidade na complexidade organizacional do espaço (SCHIFFER, 2010, p.7).

\subsection{SÍNTESE DO CAPÍTULO}

Os resultados apontam que processos tafonômicos são concomitantes e indissociáveis das atividades humanas, sendo pouco evidente que materiais arqueológicos se encontram alocados e delimitados somente a partir de solos de ocupação. Tendo em vista a configuração do espaço, da composição sedimentar, da distribuição de material e das remontagens efetuadas, duas configurações espaciais podem ser sugeridas com razoável probabilidade.

A primeira refere-se à presença de um espaço situado na porção mais abrigada do sítio, cuja estrutura do embasamento rochoso é mais rasa, e comporta, além das estruturas de combustão, uma área central com todas as matérias- primas e boa parte das remontagens efetuadas, depositadas em uma camada arenosa de fina textura e datações radiométricas estabelecidas em até 2.000 AP. O segundo contexto começa a delinear-se a partir do metro K, 
apresentando o início de uma transição para uma camada sedimentar mais escura com datações radiométricas que comporta uma extensa cronologia de 550 AP até 3400 AP. Este se localiza na porção limítrofe entre a área abrigada e não abrigada, configurando áreas relacionadas às matérias-primas sílex, arenito silicificado fino e grosso.

O ponto fulcral sobre a interação entre matérias-primas e comportamento deposicional indica que o sílex, o arenito silicificado fino e grosso e o óxido de ferro nunca deixaram de estar associados aos mesmos pontos. A única matéria-prima lítica que não possui este comportamento é a rocha verde, alocada em áreas mais abrigadas e níveis estratigráficos mais superficiais. Esta análise permite concluir que a associação e presença do sílex e do arenito silicificado ao óxido de ferro revelam que a atividade de lascamento e a atividade de produzir arte parietal corresponderam a uma longa cronologia, dado corroborado pela análise do óxido de ferro com marcas de uso, enquanto a rocha verde parece elemento introduzido em tempos recentes.

A partir destes resultados, podemos inferir que a ocupação deste local desempenha um papel central em apresentar sinais de uma progressiva diluição e ou mistura de contextos caçadores-coletores tardios e ceramistas e a interação entre registro parietal e evidências arqueológicas presentes no solo de ocupação. Essa reflexão abre perspectivas sobre as relações que ocorrem em patamar tecnológico e simbólico, sendo necessário discriminar e delimitar as etapas de processamento de material e realizar a cadeia operatória, associando-a as áreas de deposição. 


\section{Capítulo IV}

\section{OS PROCESSOS TECNOLÓGICOS NAS MATÉRIAS-PRIMAS LÍTICAS}

Quando te deparastes com uma contradição, faze uma distinção. Adágio Escolástico

Neste capítulo será apresentado o argumento de que a indústria lítica de Abrigos Vermelhos não é prontamente expedita no sentido de alcançar determinado fim, sem que haja um conjunto de processos técnicos atuantes. Pretende-se demonstrar que a aparente falta de padronização morfológica dos artefatos não corresponde à ausência de habilidade dos artesãos ou involução técnica, ocorrida a partir de repertórios tecnológicos líticos mais antigos e sofisticados.

A variabilidade artefatual lítica não decorre de ocasiões fortuitas e resultantes do aproveitamento de suportes variados, sem que houvesse emprego intencional de ações técnicas, ou que fossem confeccionados apenas conforme a qualidade e ou disposição das matérias-primas locais. O estudo do tratamento tecnológico das indústrias líticas do holoceno médio no planalto central é resultado de metodologias diversificadas que tentam explicar sua característica central ou o que se convencionou denominar expediência lítica.

Indubitavelmente, as tipologias formuladas (SCHMITZ et. al.,1986), os estudos baseados no discernimento dos procedimentos tecnológicos (FOGAÇA, 2001; VIANA, 2005; MELLO, 2005) ou no potencial da experimentação e replicação do material lítico (MILLER, 2009), lidam com o conceito estabelecido na década de 1970 por Lewis Binford, ao formular um modelo de mobilidade territorial de caçadores coletores baseado em estudos etnoarqueológicos.

Esta questão abrange a indústria lítica de Abrigos Vermelhos, caracterizada como pouco formalizada. A definição de Binford para a expediência lítica refere-se a artefatos com pouca especificidade formal e pouca elaboração técnica, de uso circunstancial de objetos conforme a necessidade, disponibilidade e reaproveitamento de matérias-primas. Em síntese, "ferramentas expedientes seriam aquelas utilizadas para as necessidades do momento, produzindo conjuntos tecnologicamente mais simples e formalmente menos padronizados" (BINFORD, 1979, p.264-266).

A partir deste modelo teórico, derivou-se uma gama de interpretações que vincularam 
a existência destas indústrias ao processo de sedentarismo. Dentre estes, o modelo mais influente foi elaborado por William Parry e Roberto Kelly na década de 1980, propondo que a expediência lítica representasse a transição para um processo de sedentarismo e formação das primeiras concentrações de aldeias (PARRY \& KELLY, 1987, p.286).

Além disso, outras explicações baseadas na discriminação da tecnologia basearam-se no argumento de que conjuntos artefatuais de redução bifacial seriam mais comuns a uma estratégia de movimentação maior no território versus conjuntos expedientes. Estes conjuntos expedientes não seriam carregados em função do baixo investimento técnico e meios menos sistemáticos de obtenção de artefatos (TOMKA \& CAMERON, 1993, p.208), demonstrando que o maior investimento técnico estaria voltado para a portabilidade dos tool kits, o que significaria a mobilidade de caçadores-coletores no território (SHOTT, 1986, p.19-34).

Também foram formuladas hipóteses a respeito do papel que a qualidade da matériaprima exerce na produção destes repertórios líticos, sendo suas características determinantes ora mais, ora menos formais, estariam relacionadas à proximidade das fontes de matériaprima de um sítio arqueológico, independente se produzidos por caçadores-coletores ou se produzidos por grupos sedentários (GOULD, 1980, apud, ANDREFSKY, 1994, p.24).

Estes modelos obtiveram o êxito em substituir a interpretação da expediência como uma involução técnica ou degeneração das habilidades dos artesãos (Adan, 1927, p.167, apud, PARRY \& KELLY, 1987, p.295). No entanto, apresentam problemas interpretativos inerentes ao fato de considerar este tipo de registro arqueológico pouco versátil, oportunístico e dependente unicamente de condições externas, representante de um padrão oposto a uma tecnologia necessariamente especializada e com design definido.

A análise da indústria lítica de Abrigos Vermelhos nos permite considerar que as circunstâncias envolvidas na deposição artefatual lítica estão estruturadas dentro de esquemas significativos aos indivíduos envolvidos em um quadro não improvisado. Neste estudo incluímos os processos técnicos executados com o óxido de ferro, tratando-se de material litológico destinado a produzir uma tecnológica de encantamento no espaço.

Não obstante, sua observação restringe-se aos aspectos de cunho técnico e mesmo da distribuição espacial deste material, uma vez que quase não se nota que as matérias-primas líticas pouco transformadas, composta por pedaços de blocos, seixos e plaquetas quebradas de óxido de ferro é o material que de fato se molda às mãos dos artesãos sendo alteradas pela destreza gestual daqueles que produzem a arte rupestre.

Isto posto, o trato com o material lítico definiu o tipo de metodologia utilizada. Partir da matéria-prima e não da tecnologia foi um caminho escolhido para lidar com a principal 
característica deste registro arqueológico, ou mais detalhadamente com a brevidade e variabilidade das sequências de lascamento. As classificações de coleções líticas geralmente são estabelecidas a partir da morfologia das peças ou da classificação tecnológica. Desse modo, a matéria-prima não costuma ser utilizada como base tipológica ou parâmetro classificatório para discernimento da tecnologia lítica (PROUS, 1986-1990, p.2).

Não obstante, um método de análise sempre parte de um problema a ser solucionado, sendo alusivo e subjacente aos preceitos teórico-metodológicos aos quais está implícito. Assim, optou-se pela caracterização litológica da indústria lítica, para em seguida, delinear o perfil técnico em cada conjunto litológico. A partir desta metodologia pretende-se encontrar denominadores comuns entre os processos técnicos executados que remetessem a métodos de redução específicos.

A partir destas considerações, será apresentada a seguir a análise do material lítico e a síntese sistemática dos dados de análise cujo objetivo é discriminar as cadeias operatórias de produção artefatual, para em seguida as relacionarmos ao seu contexto de deposição. 


\subsection{CLASSIFICAÇÃO DAS MATÉRIAS-PRIMAS LÍTICAS}

$\mathrm{Na}$ análise de agrupamento analisamos apenas o sílex que representa 20,1\% da coleção lítica e o arenito silicificado que perfaz $63,7 \%$, compondo juntos $83,8 \%$ da coleção, [tabela 9]. Embora haja discussão sobre a nomenclatura estabelecida para o sílex conforme as propriedades físicas apresentadas por esta matéria-prima (ARAUJO, 1992, 106-107), segundo Goodman (2009, p. 22), não há nenhum conjunto de padrões estabelecidos categoricamente sobre qual nomenclatura adotar, de modo que a terminologia depende da tradição ao qual o pesquisador se vincula e continuamos a denominá-la sílex. Para a rocha verde e o óxido de ferro não foram efetuadas a análise de agrupamento, restringindo-se à parcela que apresenta algum estigma de lascamento.

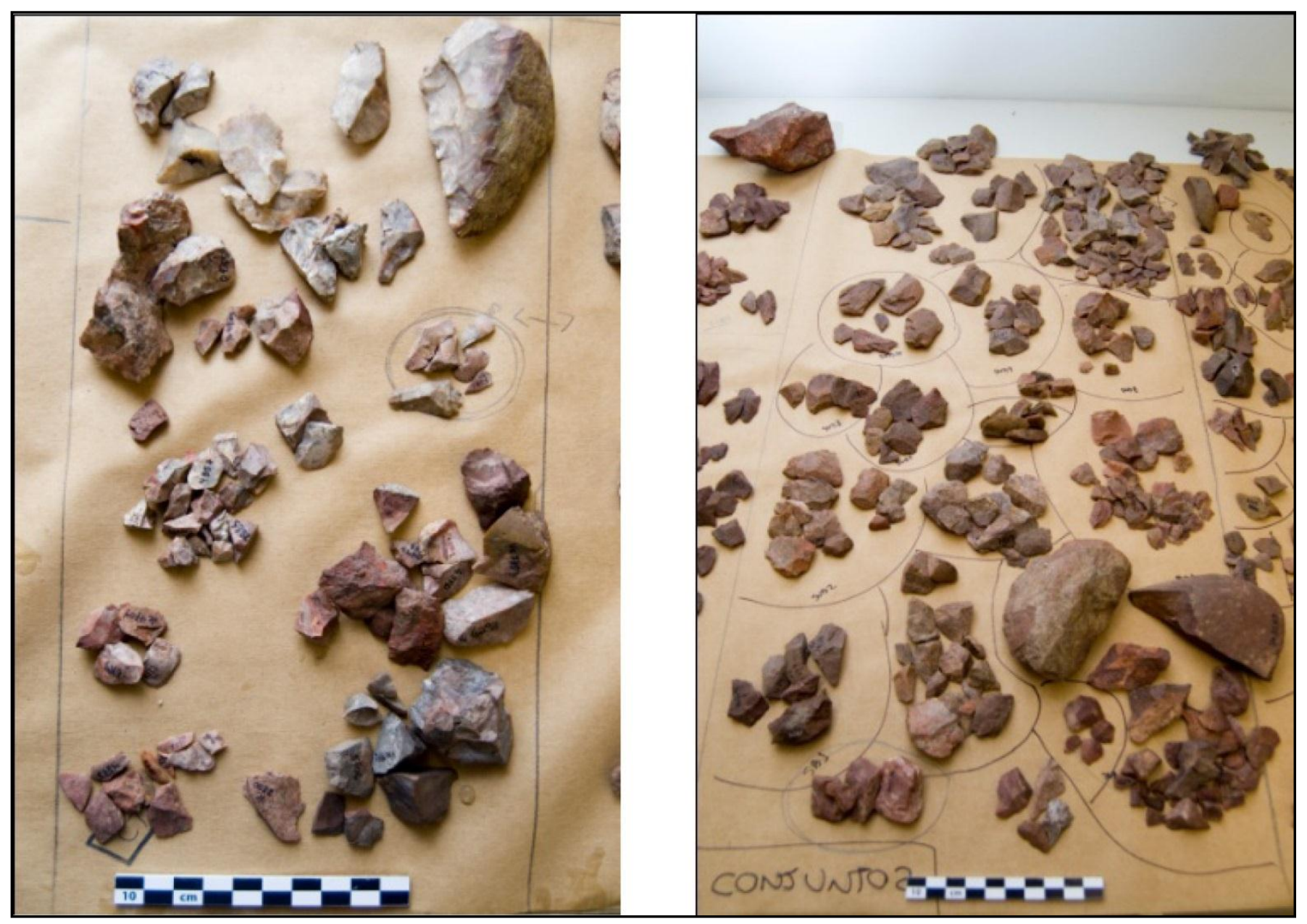

Figura 40 - Microsequências de lascamento observadas no sílex e no arenito silicificado. Foto - A. Gotardo, 2013. 
Os atributos de análise referem-se às características consideradas importantes e elencadas na qualidade do talhe, ou "aquelas que se referem às qualidades de homogeneidade, elasticidade e textura das rochas" (MILLER, 2009, p.10). Estes parâmetros qualitativos foram analisados em cada peça, sendo observado em lupa binocular, o nível de compactação, o tipo de granulometria e a homogeneidade da textura das rochas, conforme descrito a seguir.

- Compactação - Segundo Suguio (1980, p.191), a compactação é o nível de cimentação da rocha, sendo um processo que ocorre em um dos últimos estados na formação das rochas sedimentares e pode ser tomada como uma medida grosseira do grau de compactação. Os parâmetros macroscópicos de observação avaliaram o nível de agregação entre os grãos, utilizando uma escala visual e o tato, indo do grão muito desagregado e esfacelado a uma total coesão do cimento ou das características que uma rocha poder armazenar em seus interstícios.

- Granulometria - Os parâmetros macroscópicos de observação da granulometria avaliaram a visibilidade do grão na superfície da rocha. Sem a possibilidade de medilos, consideramos a finura ou aspereza da textura ao toque das mãos.

- Homogeneidade - Constatação de superfícies lisas e contínuas, não apresentando quaisquer sinais de descontinuidades físicas, ou a presença de nódulos, zonamentos ou aglomerações e incrustações específicas, ou uma mistura de ambos numa mesma peça.

\begin{tabular}{|c|c|c|c|}
\hline & Variáveis & Atributos & \\
\hline \multirow[t]{3}{*}{1} & Compactação: & Agregação incipiente dos grãos & 1 \\
\hline & & Agregação parcial dos grãos & 2 \\
\hline & & Agregação total dos grãos & 3 \\
\hline \multirow[t]{3}{*}{2} & Granulometria & Grãos não visíveis a olho nu, superfície lisa & 1 \\
\hline & & Grãos visiveis a olho nu, superficie lisa & 2 \\
\hline & & Grãos visiveis a olho nu, superficie rugosa & 3 \\
\hline \multirow[t]{3}{*}{3} & Homogeneidade & Sem qualquer descontinuidade na superficie & 1 \\
\hline & & Zonamentos ou incrustações especificas & 2 \\
\hline & & Zonamentos e incrustações especificas & 3 \\
\hline
\end{tabular}

Tabela 8 - Atributos de análise das matérias primas sílex e arenito silicificado. 
Após estabelecida a classificação macroscópica das rochas sedimentares, realizamos uma análise de Componentes Principais (Principal Components Analysis) para detectar qual variável estaria influenciando esta classificação. Esta análise é um dos métodos estatísticos multivariados que permite identificar a relação entre as características extraídas dos dados e o arranjo que melhor representa sua distribuição (EVERITT, et. al., 2001, p.22-23), conforme observado na [Figura 41].

Nesta análise, a PC 1 é a direção de menor variação e a PC 2 é a de maior variação. O resultado da análise aponta que o atributo compactação é a variável com maior variabilidade, pois estabelece uma relação inversa com os demais atributos analisados, de modo que a granulometria e a homogeneidade apresentam correlações positivas entre si e a compactação permanece isolada. Assim, as componentes principais que discriminam e produzem a variabilidade da classificação, são as qualidades de compactação ou os processos de cimentação que as rochas apresentam.

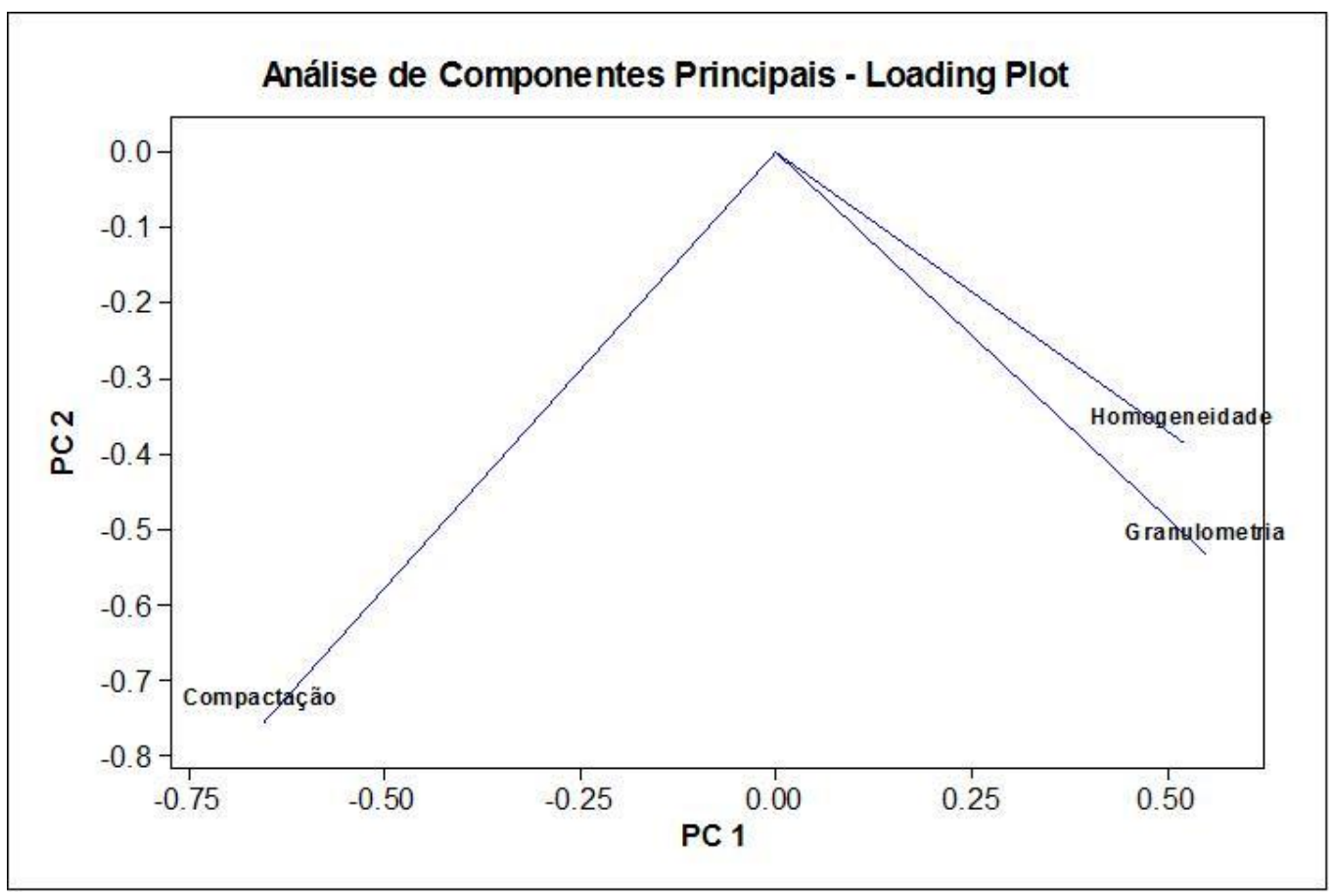

Figura 41- Análise de PCA (Análise de Componentes Principais).

Este resultado é compatível com a análise do agrupamento ou cluster, cuja conclusão culminou num isolamento parcial das rochas sedimentares clásticas (arenito silicificado) em torno do nível de compactação e maior indistinção das características de granulometria e homogeneidade. Este resultado é inverso para as rochas sedimentares não clásticas (sílex), de 
modo que o fator discriminante é o critério de homogeneidade destas rochas, ou a presença de nódulos, incrustações ou impurezas em detrimento das qualidades de cimentação e granulometria, vistos na [Figura 42].

Para a realização da classificação dos conjuntos litológicos optamos pela análise de cluster, sendo este um arranjo dos dados que permite estabelecer uma classificação. A técnica escolhida foi a aglomeração e hierarquização dos dados que dividem conjuntos inteiros de dados em $(\mathrm{N})$ grupos. Estas hierarquias tratam-se em alguma medida do processo de classificação taxonômica, ilustrativamente conhecido como dendrograma (EVERITT, et. al., 2001, p.54).

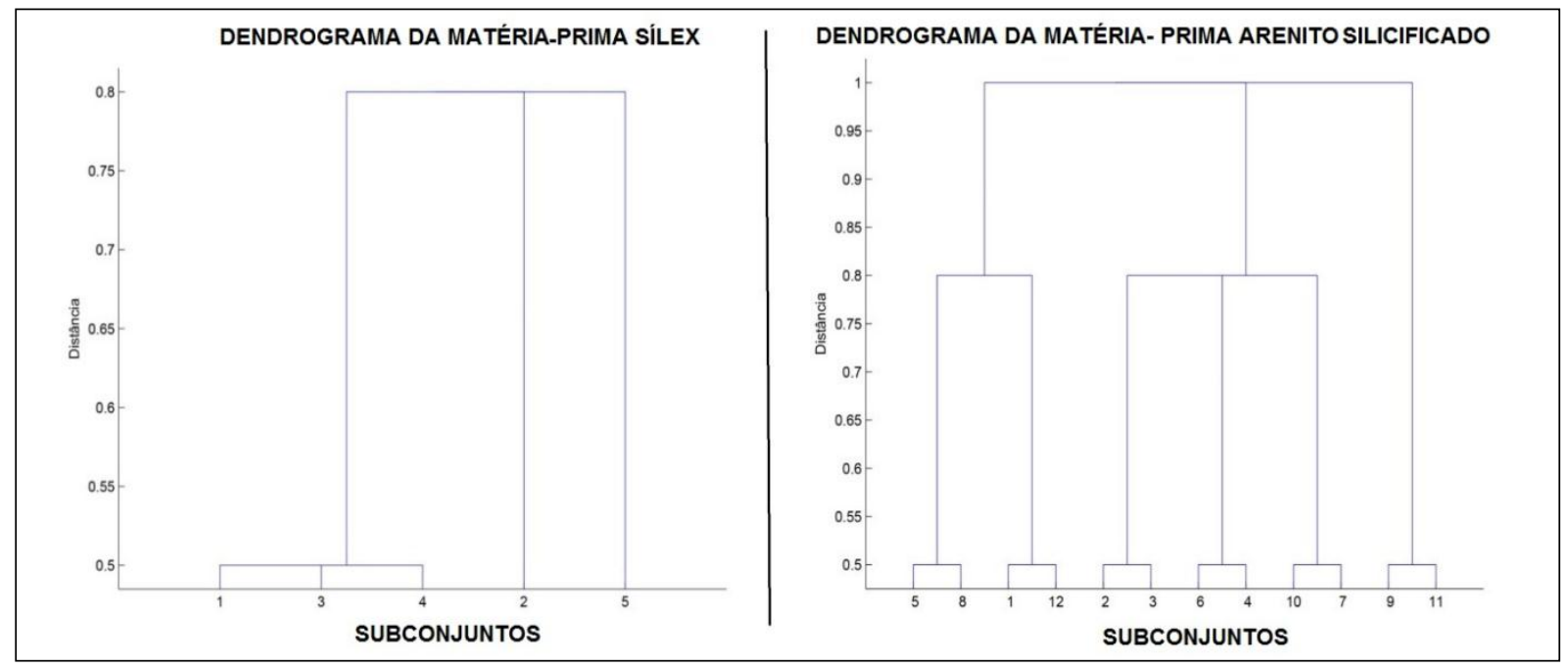

Figura 42 - Dendrogramas da análise de agrupamento de sílex e arenito silicificado.

Tendo em vista o dendrograma 1, gerado para o conjunto em sílex, formam-se dois subconjuntos com distinções marcantes nesta matéria-prima, representados pelos subconjuntos 2 e 5 e os subconjuntos $1,3,4$. O primeiro subconjunto 2 e 5 é composto por matéria-prima com incrustações, nódulos, estratigrafias ou descontinuidades importantes. $\mathrm{O}$ segundo conjunto, representado pelos subconjuntos 1, 2, 3 apresenta um matéria-prima de melhor qualidade, com incrustações, nódulos ou descontinuidades físicas mais atenuadas. Tendo em vista este resultado, agrupamos os subconjuntos 2 e 5 no conjunto 1 de sílex e os subconjuntos 1,3,4 no conjunto 2 de sílex.

O dendrograma 2, gerado para o conjunto de arenito silicificado também apresenta dois subconjuntos distintos representados pelos subconjuntos 9 e 11; e $5,8,1,12,2,3,6$, 4, 10, 7 com distâncias bem menos marcantes entre si. Dentre estes subconjuntos estão ainda 
contidas três subdivisões representados pelos subconjuntos 5 e 8 e 1 e 12 , e o segundo representado pelos subconjuntos 2 e 3, 6 e 4 e 10 e 7. Dada a pouca distância estabelecida entre os subconjuntos, optou-se por avaliar individualmente cada um deles, de modo a não reunirmos em macroconjuntos as peças constituintes dos subconjuntos, preservando as diferenciações estabelecidas entre arenitos silicificados grosseiros e arenitos silicificados finos.

\subsection{CLASSIFICAÇÃO TECNOLÓGICA DO MATERIAL LÍTICO DE ABRIGOS VERMELHOS}

A classificação tecnológica do material lítico inclui a caracterização geral da indústria lítica e a caracterização tecnológica de cada conjunto litológico. Optou-se pela análise dos atributos qualitativos e quantitativos, utilizando a estatística descritiva realizada no software SPSS (Statistical Package for the Social Sciences). A estatística descritiva atua por meio da sumarização do conjunto de dados, frequências, medidas de tendência central e dispersão (MADRIGAL, 1998, p.9).

Adotamos como critério o discernimento das matérias-primas, traçando-se o perfil geológico da coleção. Em seguida, discriminamos as classes de análise que caracterizam o lascamento. Para tal, definimos os atributos de análise ancorados em base bibliográfica que inclui trabalhos que descrevem a tecnologia de materiais líticos (VIALOU; 1980; BRÈZILLON, 1983; TIXIER et. al., 1992; CRABTREE, 1982, DeBLASIS, 1988; ANDRESFSKY, 2002) e ainda uma base bibliográfica que trata especificamente de indústrias líticas brasileiras com ênfase no planalto central (FOGAÇA, 2001, BUENO, 2007; VIANA, 2005, LOURDEAU, 2010). Sinteticamente as definições das classes de análise serão expostas a seguir para que haja uma compreensão dos sentidos empregados na discriminação técnica.

Tomamos a definição de lascas como "produtos de lascamento com caracteres técnicos particulares" (VIALOU, 1980, p.77), pois, o discernimento de processos técnicos é o interesse deste capítulo.

Lascas classificadas como simples referem-se à parcela de material inconclusivo sobre as técnicas aplicadas sem que possam ser alocadas em alguma etapa de redução específica. Outras classificações foram geradas para lascas conforme as distinções dos procedimentos técnicos, observando-se que lasca inicial é aquela que "em teoria é a primeira removida de um bloco de matéria-prima” (TIXIER et. al., 1992, p.85-86), enquanto lasca de descorticamento “objetiva desbastar o núcleo” (DeBLASIS, 1988, p.78), mas, não necessariamente refere-se as 
primeiras etapas de lascamento, de modo que a variação cortical resulta numa série de elementos, tais quais tipo de matéria prima ou intensidade de redução (SULLIVAN \& ROZEN, 2009, p.308). Lasca de flanco do núcleo e de reavivagem "provém do processo de reciclar ou reativar o bordo de um núcleo" (DeBLASIS, 1988, p.78), e, as lascas de preparo de núcleo foram consideradas aquelas "destacadas de um núcleo durante sua preparação" (TIXIER et. al., 1992, p.87), cuja preparação implica em procedimentos técnicos que levam a resultados específicos (TIXIER et. al., 1992, p.94). Lascas siret são consideradas "acidentes de lascamento", enquanto lasca de retoque foram consideradas "remoções por percussão ou pressão que para obter-se ou finalizar um artefato" (TIXIER et. al., 1992, p.67). As lascas de acabamento são consideradas uma categoria a parte, pois, tomamos como definição o “resultado de confecção de artefatos" (DeBLASIS, 1988, p.78) e ampliamos esta definição conforme o conceito de façonnage ou a "sequência operacional que impõe uma forma particular à matéria" (TIXIER et. al., 1992, p.41), ou ainda, "etapas sucessivas de redução de um bloco tendo em vista a produção de um artefato" (LOURDEAU, 2010, p.94-95).

Ainda sobre a classificação adotada para as classes de análise foram identificados os artefatos. Artefatos conforme definição uma definição formal pode ser compreendido como "um engenho construído para um fim determinado" (HOUAISS, 2011, p.84), enquanto instrumentos e ferramentas são considerados sinônimos ou "recursos utilizados como intermediário para se chegar a um resultado" (HOUAISS, 2011, p.543). Fragmentos de artefatos são vistos como constituintes de peças que outrora possuíam características identificáveis como artefatos, e fragmentos de núcleos são considerados massas fragmentadas “debitadas para prover suportes para confecção de ferramentas” (TIXIER et. al., 1992, p.84).

Fragmentos e suportes pouco modificados assumem importância nesta análise. Fragmentos referem-se às fraturas ocasionadas pelo destacamento de lascas em alguma etapa de debitagem, enquanto os suportes pouco modificados são considerados matérias primas levadas ao sítio que sofrem transformações discretas. Nesta categoria, estão contidas plaquetas não usadas; seixos não usados, fragmentos de seixo que apresentam geralmente reserva cortical, mas não estigmas de lascamento, blocos de fogueiras lascados e fragmentos térmicos, identificados por cúpulas, enrugamento e destacamento por espatifamento.

Para a análise dos atributos quantitativos buscamos a estrutura da distribuição das médias, lembrando que a média é "a tendência central para dados numéricos" (MADRIGAL, 1998, p.31), de modo que, quando não existe uma relação estrutural das médias, costuma-se aplicar o teste de comparação das médias marginais. O objetivo principal é "estudar a relação entre variáveis, analisando a influência que uma ou mais variáveis tem sobre uma variável de 
interesse" (TURKMAN et. al., 2000, p.1).

As análises quantitativas neste trabalho restringem-se a correlações estabelecidas para o comprimento e largura das peças, capaz de informar sobre o perfil da indústria, se elaborada sobre lascas, sobre lâminas, entre outras possibilidades; na relação estabelecida entre comprimento e espessura, apropriada para informar sobre o controle da redução; e a relação entre largura e espessura que pode produzir informações sobre tipos de redução unidirecional ou multidirecional (ANDREFSKY, 2002, p.159). Esta análise torna-se particularmente interessante em função da possibilidade de indicar padrões técnicos e formas de percussão (PROUS, 1986-1990, p.20), fornece ainda pistas sobre a forma de exploração dos suportes (BUENO, 2007, p.82), em uma indústria cujas cadeias operatórias precisam ser descritas, mas carece de núcleos ou lascas suporte.

\subsubsection{Análise geral da indústria lítica de Abrigos Vermelhos}

Das 4.253 peças distribuídas na estratigrafia, 3.397 foram selecionadas para a análise tecnológica da cadeia operatória da série de lascas e 42 artefatos selecionados para a análise tecnológica de cada peça. Os resultados de análise sugerem que as matérias primas levadas e ou processadas em Abrigos Vermelhos são diferentes em quantidade e qualidade, sobressaindo o arenito bem ou mal silicificado $63,7 \%$, seguido pelo sílex 20,1\%, óxido de ferro $\left(\mathrm{Fe}_{2} \mathrm{O}_{3}\right) 10 \%$ e rocha verde 6,2\%, [tabela 9], revelando um perfil geológico diversificado que exigiria respostas diferenciadas quanto ao lascamento, contudo, com predomínio de material propício ao trabalho do talhe representado pelo sílex, arenito silicificado e rocha verde.

\begin{tabular}{lrrrr}
\hline \multicolumn{5}{c}{ Distribuição das Matérias Primas } \\
\hline \multicolumn{1}{c}{ Matérias Primas } & Frequência & Percentual & Percentual Válido & Percentual Acumulativo \\
Sílex & 683 & 20,1 & 20,1 & 20,1 \\
Rocha Verde & 209 & 6,2 & 6,2 & 26,3 \\
Óxido de Ferro & 341 & 10,0 & 10,0 & 36,3 \\
Arenito Silicificado & 2164 & 63,7 & 63,7 & 100,0 \\
Total & 3397 & 100,0 & 100,0 & \\
\hline
\end{tabular}

Tabela 9- Distribuição dos materiais líticos. 
As classes de análise concernem às classificações estabelecidas a partir dos atributos contidos no APÊNDICE 1, resultando na constatação de que o trabalho de debitagem e ou façonnage, representados pelas lascas, fragmentos, fragmento térmico, fragmento de núcleo e fragmento de lasca são predominantes e juntos comportam 89,3\%, que artefatos e fragmentos de artefatos são minoria e representam $2,9 \%$ da coleção e que evidências da modificação do óxido de ferro ou de um trabalho paralelo ao da redução de suportes, associado à produção de arte abarca fragmentos de seixos, plaquetas não usadas, seixos não usados e fragmentos usados e representam $7,7 \%$ do total, [tabela 10].

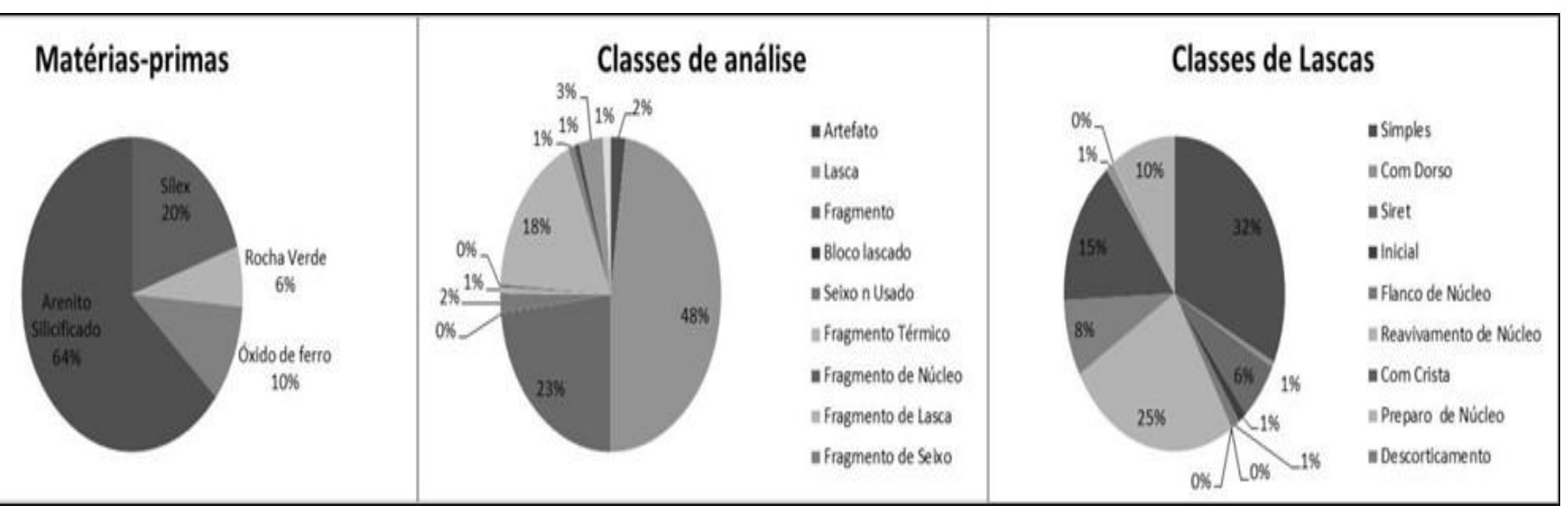

Figura 43 - Gráfico com a distribuição das matérias-primas, das classes de análise e das classes de lascas.

\begin{tabular}{|lrr|}
\hline \multicolumn{3}{|c|}{ Classes } \\
\hline & Frequencia & Percentual \\
\hline Artefato & 76 & 2,2 \\
Lasca & 1660 & 47,8 \\
Fragmento & 797 & 22,9 \\
Bloco Lascado & 5 &, 1 \\
Seixo não usado & 71 & 2,0 \\
Fragmento Térmico & 21 &, 6 \\
Fragmento de Núcleo & 10 &, 3 \\
Fragmento de Lasca & 616 & 17,7 \\
Fragmento de Seixo & 31 &, 9 \\
Fragmento de artefato & 26 &, 7 \\
Plaquetas não usadas & 120 & 3,5 \\
Fragmentos usados & 40 & 1,2 \\
Total & 3473 & 100,0 \\
\hline
\end{tabular}

Tabela 10 - Classes de análise do material lítico. 
4.2.2 Correlação entre comprimento, largura e espessura

A análise das séries de lascas permitiu detectar que a debitagem e a façonnage juntas compõem $61 \%$ da amostra. As etapas discerníveis de cadeias operatórias representam 67,8\% do material, enquanto $32,2 \%$ foi considerado lascamento simples, cujas lascas não puderam ser alocadas em alguma etapa de redução específica, [Tabela 11].

Aponta-se que dentre as lascas com indícios de redução discernível, as primeiras etapas compostas por lascas iniciais e de descorticamento agregam 9,1\% da amostra, etapas de preparo de núcleo $25 \%$, e etapas de finalização de artefatos concernentes às lascas de acabamento/ façonnage somam $15,1 \%$ e de retoque $9,3 \%$, tabela 11 . Destaca-se também que em menor medida está presente um sistema de redução caracterizado com lascamento por percussão sobre bigorna, ou, bipolar, que perfaz 1,1\% do total analisado, [Tabela 11].

A análise das séries das lascas da indústria lítica de Abrigos Vermelhos demonstra que um sistema de redução de núcleos organizados está presente e que além delas, também etapas de estruturação ou finalização de artefatos, de modo que as etapas iniciais de desbastamento são menos corriqueiras. Isto significa dizer que etapas intermediárias e finais de redução prevalecem na coleção. Resta, entretanto, discernir os métodos aplicados nas produções dos suportes e de artefatos.

\begin{tabular}{|c|c|c|}
\hline \multicolumn{3}{|c|}{ Distribuicão das Lascas } \\
\hline & Frequencia & Percentual \\
\hline Simples & 534 & 32,2 \\
\hline Com Dorso & 9 & 5 \\
\hline Siret & 102 & 6,1 \\
\hline Inicial & 20 & 1,2 \\
\hline Flanco de Núcleo & 21 & 1,3 \\
\hline Reavivamento de Núcleo & 1 & 1 \\
\hline Com Crista & 1 & 1 \\
\hline Preparo de Núcleo & 415 & 25,0 \\
\hline Descorticamento & 131 & 7,9 \\
\hline Acabamento/ façonnage & 251 & 15,1 \\
\hline Bipolar & 19 & 1,1 \\
\hline Laminar & 1 &, 1 \\
\hline Retoque & 155 & 9,3 \\
\hline Total & 1660 & 100,0 \\
\hline
\end{tabular}

Tabela 11 - Distribuição das classes de análise das lascas. 
Realizar a correlação entre a distribuição das médias foi um procedimento estatístico escolhido devido à impossibilidade de observação direta dos núcleos. A correlação estabelecida entre comprimento e largura, [Figura 44 a], indica que, lidamos com uma indústria sobre lascas conforme a razão estabelecida entre o comprimento e largura das peças, e, portanto, poderíamos esperar a assimetria entre comprimento e largura, caso se tratasse de um sistema de redução laminar, por exemplo.

A correlação estabelecida entre largura e espessura, [Figura 44 b], sugere evidências de controle da retirada da espessura das lascas podendo indicar processos dependentes do tipo de núcleo, evidenciando processos multidirecionais ou em alguns casos, indícios de retiradas unidirecionais. A correlação estabelecida entre comprimento e espessura, [Figura 44 c], revela informações sobre o controle da redução em fases avançadas, exigindo acurácia técnica e esmero de produção de pequenos núcleos.

Estas informações cotejadas em relação à análise das classes das séries de lascas desvelam que todas as etapas de debitagem estão presentes na indústria em menor ou maior proporção, de modo que o perfil geral da indústria é caracterizado pela redução de núcleos e por retiradas com controle, regularidade e sequência que poderia sugerir a presença de uma cadeia operatória. 


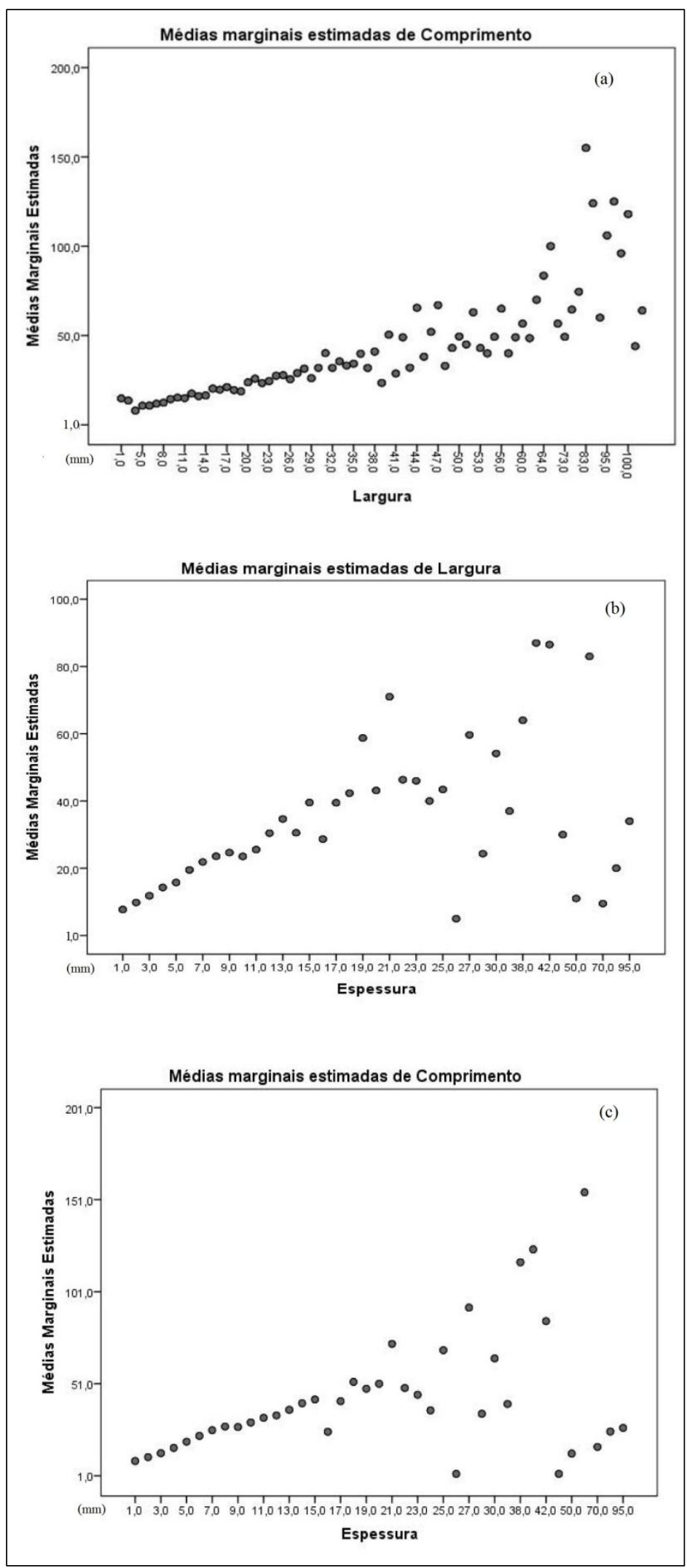

Figura 44 - Correlações entre os atributos de análise contínuos. 


\subsection{ANÁLISE TECNOLÓGICA DOS CONJUNTOS LITOLÓGICOS}

\subsubsection{Conjunto 1 de Sílex}

$\mathrm{Na}$ análise do conjunto 1 de sílex, as classes incluem lascas 42,9\%, fragmentos de lascas $26,7 \%$ e fragmentos 22,7\% [tabela 3, APÊNDICE 3], classificadas em simples 36,3\%, preparo de núcleo $(24,9 \%)$, de descorticamento $14,5 \%$, e raramente bipolares 3,6\%, revelando etapas de redução de núcleo [tabela 4, APÊNDICE 3]. O cálculo das médias marginais consideram todos os efeitos possíveis de desvios sobre as médias do comprimento e largura, indiciando que não se trata de etapas de finalização de artefatos, mas de debitagem de pequenos seixos com uma sequência regular.

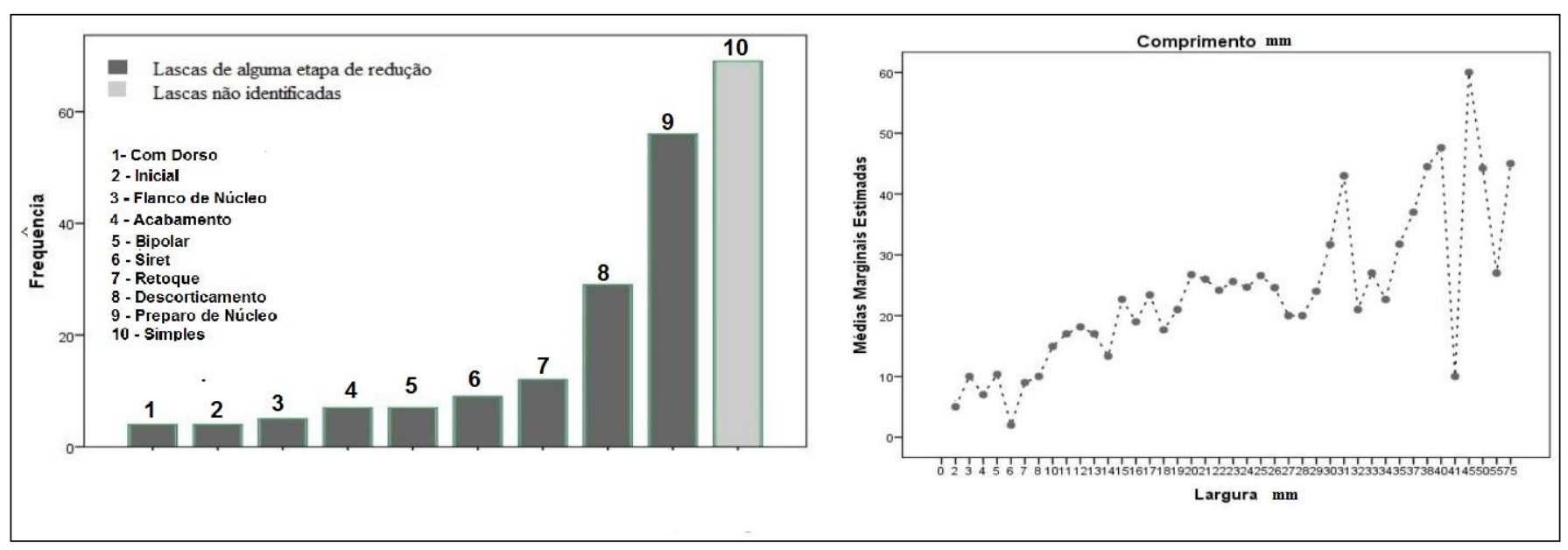

Figura 45 - Frequência das classes e média marginal (mm) C1 sílex.

Do ponto de vista técnico, seixos são trabalhados usando-se percussão direta dura $82,9 \%$, não sofrendo um preparo prévio do talão $81,7 \%$, apresentando talões lisos $67,9 \%$ [tabelas 5, 6, 7, APÊNDICE 3]. Observa-se que este conjunto detém características de preparo de núcleos organizados desde as lascas de descorticamento $14,5 \%$ ou de preparo de núcleo 24,9\% com esmero de produção em relação à parte proximal da lasca, indiciada pelo preparo de talão 18,3\%, [tabelas 4, 6, APÊNDICE 3], utilizando-se de percussão dura e presença de talões lisos, e, em menor quantidade, talões lineares $6,2 \%$ e puntiformes $6,7 \%$ [tabela 7 , APÊNDICE 3]. Observa-se que apresentam preparo do plano de percussão ao redor do talão, promovendo o adelgaçamento e a regularização da superfície externa conforme a retirada de uma série de negativos, de modo que os golpes permitem alcançar uma lasca com destaque bastante específico e previsível. 


\subsubsection{Conjunto 2 de Sílex}

Neste conjunto há o predomínio de lascas 55,4\%, (tabela 13, APÊNDICE 3) que podem ser classificadas em simples $28,7 \%$, de preparo de núcleo $20,2 \%$ e de retoque $31,8 \%$ (tabela 14, APÊNDICE 3). Há maior variabilidade nas médias marginais estimadas entre comprimento e largura, o que pode significar rupturas das etapas da cadeia operatória e que microsequências de lascamento são bastante curtas.

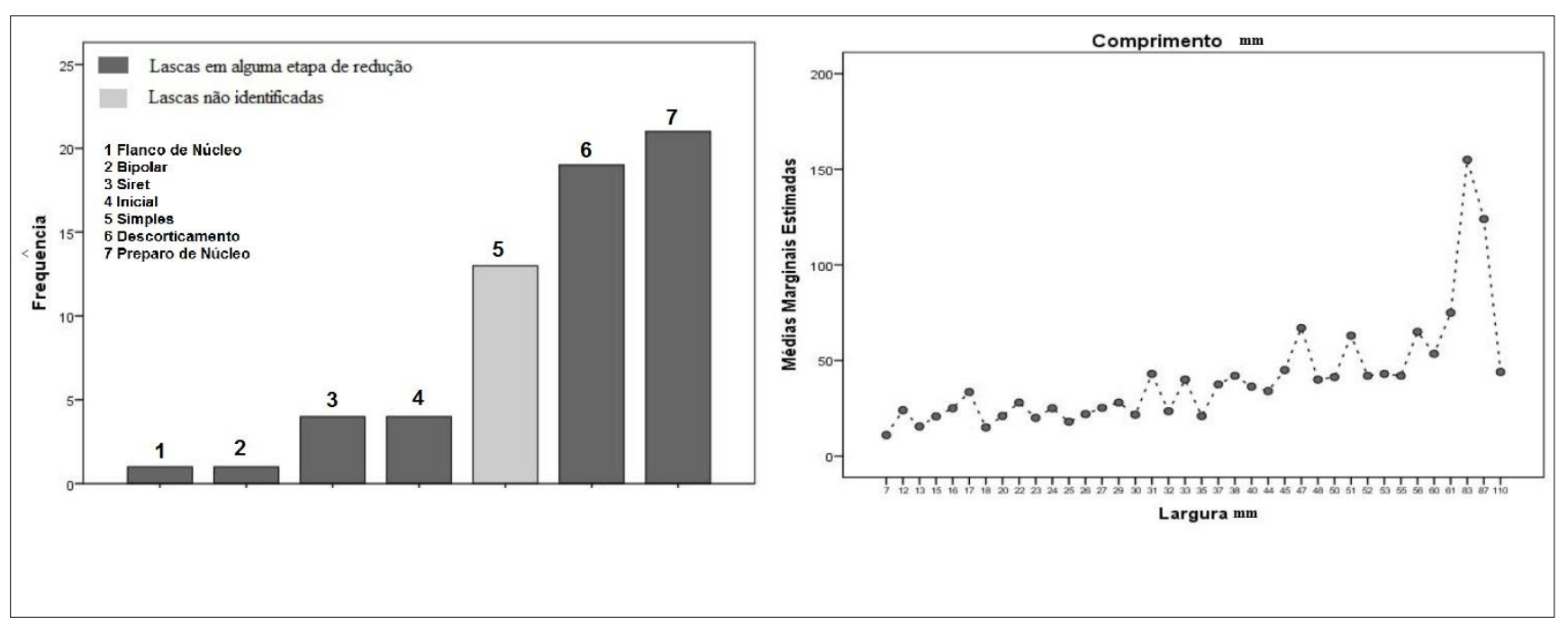

Figura 46- Frequência das classes e média marginal (mm) C2 Sílex.

Seixos pequenos estão quase completamente descorticados 91,8\% (tabela 12, APÊNDICE 3), reportando-se a etapas de redução avançada, usando-se percutor duro $55 \%$ e vestígios de uso de percussão direta macia 7\%. Os talões são lisos em 43,95\% dos casos, embora apresente talões elaborados, lineares $16,3 \%$ e puntiformes $8,1 \%$ (tabelas 15,17 , APÊNDICE 3). A espessura do talão é muito delgada, alcançando no máximo $3 \mathrm{~mm}$ em $70,5 \%$ dos casos (tabela18, APÊNDICE 3) e os ângulos de remoção com a face interna da lasca estão entre $90^{\circ}$ e $100^{\circ}$ (tabela 19, APÊNDICE 3), embora, constate-se esmero na produção e evidências de percussão direta macia a partir da presença de bulbos vagamente definidos e ângulos de percussão maiores que $90^{\circ}$, acompanhados pelo abrasão da plataforma de lascamento, conforme descrito por (TIXIER et. al., 1992, p. 61). 


\subsubsection{Conjunto 1 de Arenito Silicificado}

Este conjunto possui poucos vestígios, sendo composto por lascas 50,9\%, fragmentos de lasca $17 \%$ e fragmentos 32,1\% (tabela 23, APÊNDICE 3). Estas lascas podem ser classificadas em simples $18,5 \%$, de preparo de núcleo $37 \%$ e de descorticamento $11,1 \%$, além de lascas com indícios de redução apoiada sobre bigorna 18,5\% (tabela 24, APÊNDICE 3). As médias marginais estimadas de comprimento e largura assinalam sequências de redução com medidas regulares e maiores, indicando a presença de suportes maiores e ou etapas inicias de redução.

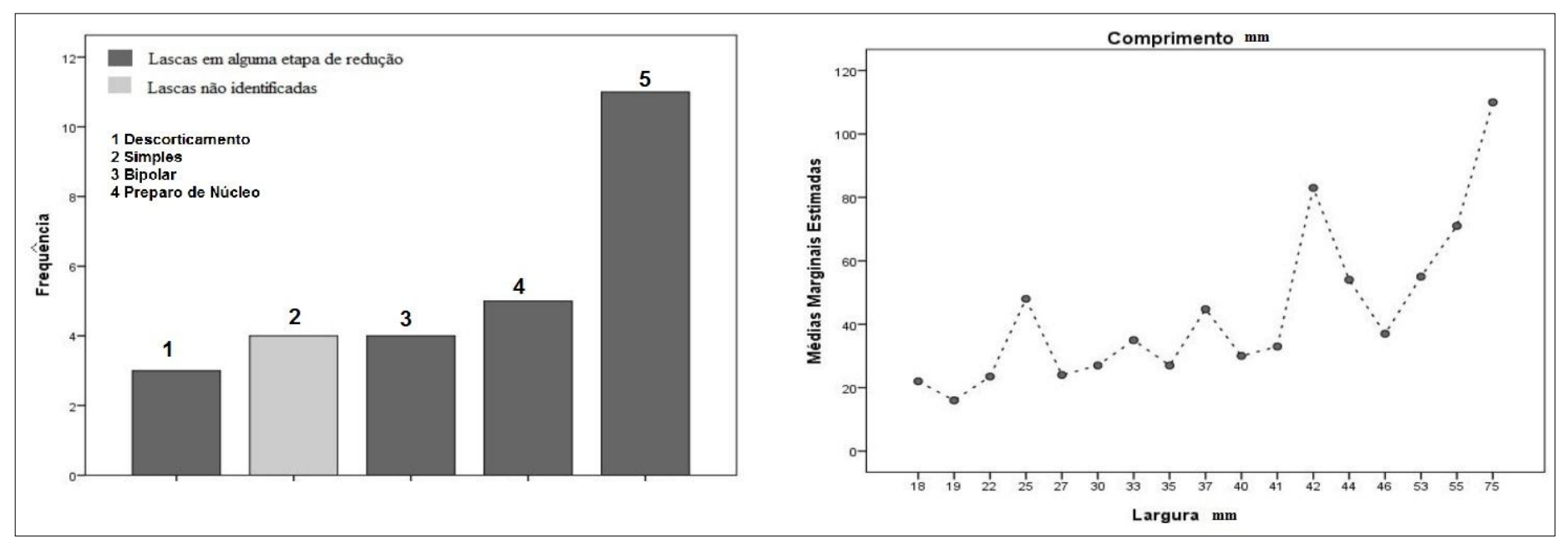

Figura 47 - Frequência e média marginal (mm) C1 arenito silicificado.

Conforme a observação de que todas as lascas possuem como suportes blocos em 100\% dos casos e a ausência de córtex em quase todos os vestígios 98,1\% (tabelas 21, 22, APÊNDICE 3), nota-se que a debitagem é realizada em fase intermediária de redução, com o destacamento de lascas espessas, planas e largas, com talões espessos e lisos, provenientes de blocos previamente destacados em outro local.

Busca-se a redução regular em um material muito friável, aventando-se a possibilidade do conhecimento e controle de técnicas de lascamento em matérias-primas pouco aptas. A percussão é direta dura em 100\% dos casos, quase não se nota preparo do talão 74,1\% (tabelas 25, 26, APÊNDICE 3), e os talões são quase são todos lisos 96,3\%. As medidas dos talões está entre $11 \mathrm{~mm}$ a $15 \mathrm{~mm}$ em 29,6\% dos casos, além destes manterem ângulos abruptos e a maioria das lascas apresentarem superfície lisa, com no máximo duas retiradas (tabelas 27 , 28, 29, 30, 31, APÊNDICE 3). 


\subsubsection{Conjunto 2 de Arenito Silicificado}

Conjunto composto por lascas $59,8 \%$ e blocos lascados 4,9\% (tabela 34, APÊNDICE $3)$, em que se destacam lascas em fase inicial de redução, consideradas de descorticamento $32,3 \%$ e preparo de núcleo $29 \%$ (tabela 35, APÊNDICE 3). Nota-se que as médias marginais estimadas entre o comprimento e a largura, são bastante similares entre si, observando-se o padrão de lascas quadráticas e espessas, demonstrando a constância da retirada destas lascas.

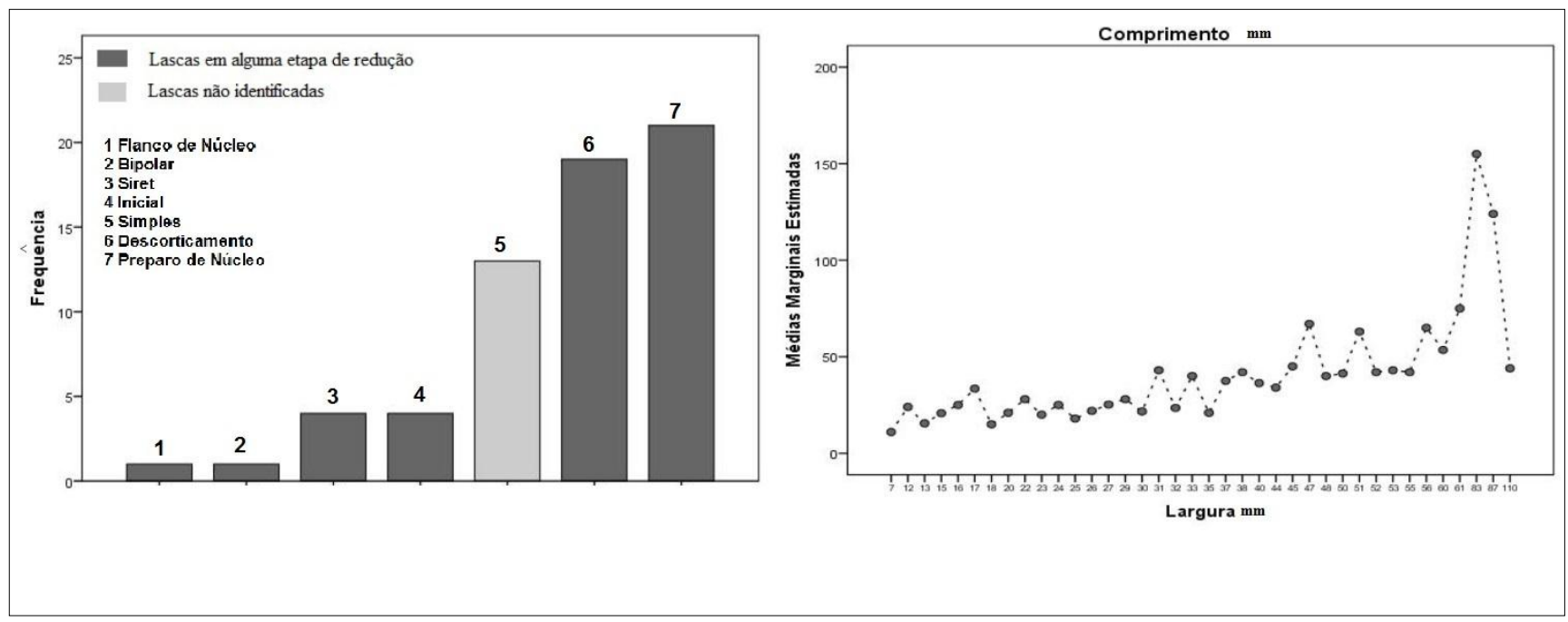

Figura 48 - Frequência da classe e média marginal (mm) C2 arenito silicificado.

A debitagem é predominantemente realizada sobre blocos ricos em óxido de ferro, a princípio pouco apto ao lascamento que representam $97,1 \%$. Dentre as lascas, um bom número delas apresenta córtex 37,3\%, enquanto as descorticadas representam 62,7\% (tabelas 32 e 33, APÊNDICE 3). Neste conjunto blocos estão sendo reduzidos no sítio desde as primeiras etapas de lascamento, usando-se percussão direta dura 73,8\%, não sofrendo um preparo prévio do talão $93,4 \%$, com destaque para o grande número de talões corticais $31,1 \%$ e lisos 67,2\% (tabela 38, APÊNDICE 3). O controle da espessura dos talões é pouco notado ao observarmos a distância do ponto de impacto em relação à margem da plataforma (CRABTREE, 1982, p.6), os ângulos são abruptos e os negativos de retiradas da face externa são poucos (tabelas 40, 41, APÊNDICE 3). 


\subsubsection{Conjunto 3 de Arenito Silicificado}

A maioria das classes é composta por lascas espessas 59,6\% e corticais 53,2\% (tabelas 44 e 45, APÊNDICE 3). São formadas por lascas em princípio de redução, embora se perceba que as etapas intermediárias se sucedem. A debitagem se faz a partir de golpes abruptos, destacando-se uma primeira lasca espessa e cortical, que criará uma plataforma de debitagem ou produzir-se-á uma nervura longitudinal que serve de guia para a retirada das lascas seguintes. As médias marginais estimadas apontam que não há um padrão regular, sugerindo talvez que seixos são abertos no sítio e descartados.

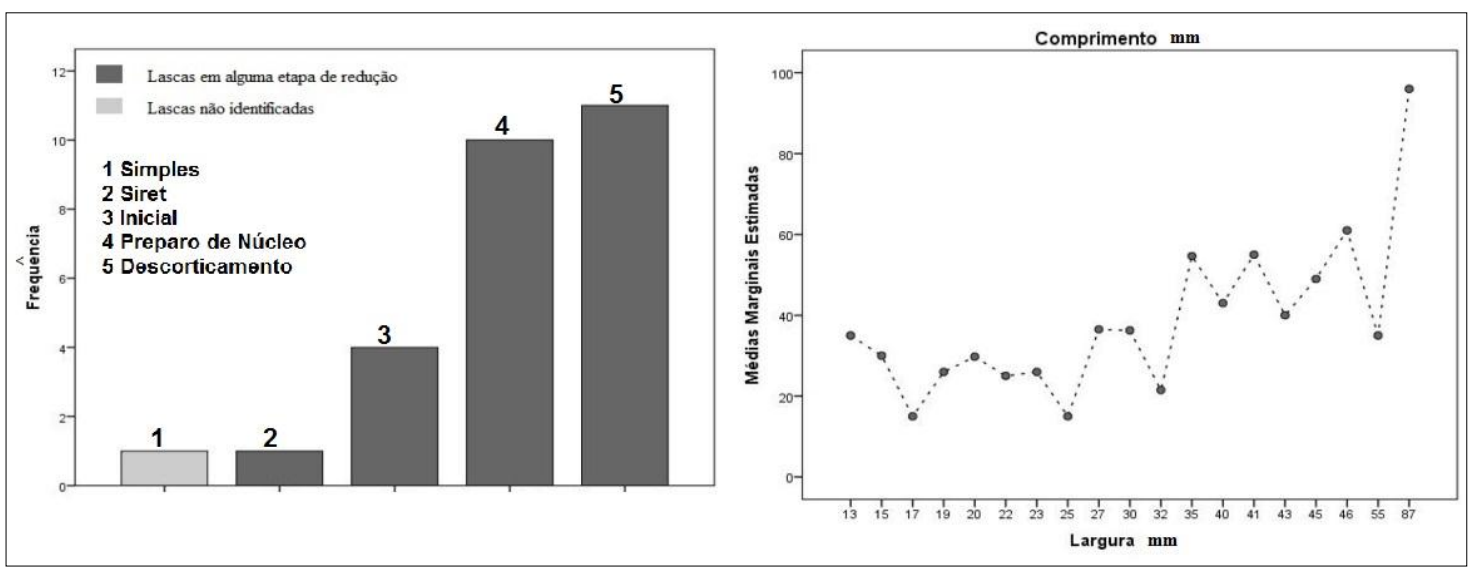

Figura 49 - Frequência e média marginal (mm) C3 arenito silicificado.

O suporte é constituído por seixos em $100 \%$ dos casos (tabela 43, APÊNDICE 3) e as lascas representam $53,2 \%$, dividindo-se em descorticamento $39,3 \%$ e preparo de núcleo 35,7\% (tabela 46, APÊNDICE 3). Estas apresentam talão liso 67,9\% e pouca preparação do talão 75\% (tabelas 48 e 49, APÊNDICE 3), formando ângulos entre a plataforma de lascamento e a superfície ventral de $90^{\circ}, 66,7 \%$ (tabela 51, APÊNDICE 3), cujo golpe é desferido perto do ponto de impacto, denotando controle do destacamento (COTTERELL \& KAMMINGA, 2009, p.65). Estas marcas de intervenção indicam redução de núcleos em início de debitagem, argumento reforçado pelo número de negativos na face externa da lasca, constituído por apenas 1 ou 2 retiradas em 89,3\% dos casos (tabela 53, APÊNDICE 3). 


\subsubsection{Conjunto 4 de Arenito Silicificado}

Conjunto constituído predominantemente por lascas 55,4\% consideradas simples $29,5 \%$ ou intermediárias $28,3 \%$ e de etapas mais avançadas de lascamento, em que constam lascas de acabamento 20,2\% (tabelas 56, 57, APÊNDICE 3). As médias marginais estimadas sugerem a presença de uma sequência organizada de redução, cuja expressão pode ser vista na correlação entre comprimento e largura, mantendo a proporção entre estas grandezas, que, portanto, tendem a serem quadráticas.

Por outro lado, também existem lascas mais compridas que largas, observando-se duas técnicas de redução: a primeiro produz lascas ligeiramente mais largas que compridas, sem a presença de aresta guia regularizadora, se aproveitando de arestas naturais. A segunda é composta por lascas mais compridas que largas, criando aresta guia central por meio de pequenas retiradas centrípetas na face externa.

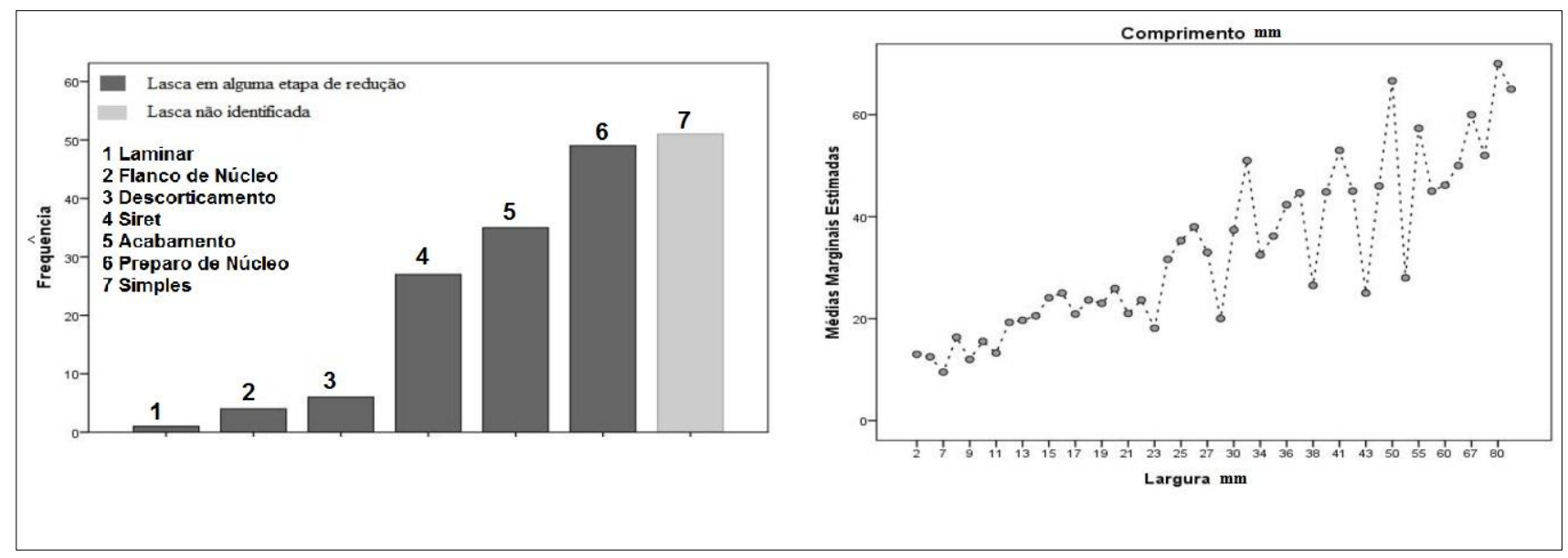

Figura 50 - Frequência e média marginal (mm) C4 arenito silicificado.

Este conjunto indica a redução de blocos $100 \%$, sem presença de córtex $99 \%$ indicativo de fases intermediárias e avançadas de redução (tabelas 54 e 55, APÊNDICE 3), no qual angulações naturais são aproveitadas para o destacamento de lascas quadráticas e volumosas. Estas lascas apresentam talões largos 7,6 mm e lisos 75,7\% (tabelas 60 e 61, APÊNDICE 3), sendo tão largas quanto compridas, destacadas em sentido longitudinal, com ângulos de $90^{\circ}$ 39,3 \% (tabela 62, APÊNDICE 3). É importante ressaltar o aproveitamento para a produção artefatual de fragmentos maciços poliédricos com formas cúbicas, os 
“cassons" (PROUS \& LIMA, 1986-1990, p. 101), ou de fragmentos mesiais de lascas com planos de fratura paralelos, que sugerem a redução de grandes suportes.

O conjunto analisado também apresenta indícios de tratamentos dos núcleos preparados para a produção de lascas suportes, algumas lascas desviadas do eixo morfológico, expondo três, quatro ou cinco retiradas da face externa $26,6 \%$ e predominância de talões lisos $75,7 \%$ (tabelas 60 e 63, APÊNDICE 3). As medidas dos ângulos estão entre $110^{\circ}$ e $80^{\circ} \mathrm{em}$ $85,4 \%$ dos casos (tabela 62, APÊNDICE 3). Cogita-se a hipótese de que trata-se de lascas que vão sendo destacadas ao redor de um eixo central.

Se isto se confirmar é importante dizer que estes núcleos estariam sendo reduzidos longitudinalmente. Nota-se a presença de uma lasca laminar no conjunto, mas devido à ausência de outras características que possa remeter a produção deste tipo de suporte, é possível afirmar apenas sua presença vestigial no sítio. Segundo Tixier et. al (1992, p. 59-61) as evidências de redução laminar devem incluir a preparação de cristas, quase sempre por remoção bifacial, e uma série de redução que deve privilegiar a relação entre ângulo e o destacamento das lascas. Desse modo "o ângulo de retirada das lascas não pode ser exageradamente abrupto, ou muito rasante, o que inviabilizaria a produção de lascas deste tipo de núcleo" (VIANA, 2005, p. 809).

\subsubsection{Conjunto 5 de Arenito Silicificado}

Conjunto composto por redução de blocos $99,4 \%$, sem córtex 99,4\%, em fase de redução de lascas 52,8\%, com um percentual alto de fragmentação 25,6\%, compostas por lascas simples 45,4\%, de preparo de núcleo 31,3\% e de acabamento 9,2\% (tabelas 65, 66, 67, 68, APÊNDICE 3). As médias marginais estimadas apresentam um padrão similar àquele estabelecida para a análise geral, figura 40 a, 40 b, 40 c, em que a redução crescente é notada em peças menores e um padrão aleatório é notado a seguir em peças maiores. 


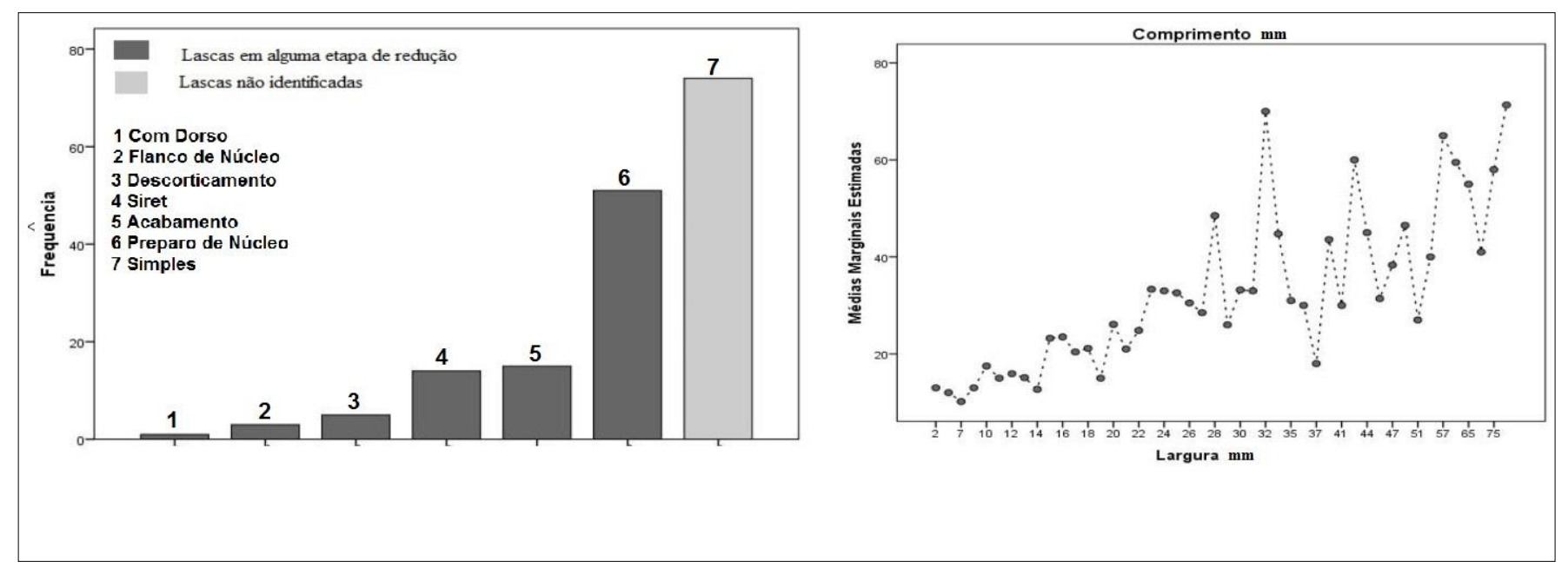

Figura 51 - Frequência e média marginal (mm) C5 arenito silicificado.

Constata-se a preferência por lascas quadráticas e por fragmentos de lascas que apresentam formas poliédricas globulares ou retangulares volumosas em fase de preparação de núcleo 31,3\% (tabela 68, APÊNDICE 3). As lascas são curtas, os talões são lisos 85,3\% e relativamente espessos (tabelas 71, 72, APÊNDICE 3), sem córtex, com preparo da superfície externa com três ou mais retiradas 25,7\% (tabela 74, APÊNDICE 3), formando arestas guias que orientam a redução e tornam a convexidade lateral do suporte mais evidente. Supõe-se que estes suportes são reduzidos mantendo a proporção entre largura e espessura, característica observada em função da frequência das médias das lascas com 28, $5 \mathrm{~mm}$ de comprimento, 25,9 mm de largura e 9,4 mm de espessura (tabela 75, APÊNDICE 3).

Observa-se também o adelgaçamento ao redor do talão de pequenas lascas, permitindo cogitar a hipótese de que este adelgaçamento remete a uma técnica de redução longitudinal. É evidente a redução de lascas em fase de preparo avançado de núcleo, com formato mais alongado que largo, na proporção de 1:2 e preparação da face externa da lasca com a criação de uma série de arestas paralelas, preferencialmente formadas por três ou quatro retiradas na face externa 24,5\% (tabela 74, APÊNDICE 3). Algumas lascas apresentam negativo central de retirada tomando praticamente toda a face externa da lasca. Observa-se também indícios da percussão fina, como a ausência de ponto de impacto e do aspecto alisado da face externa das lascas. 


\subsubsection{Conjunto 6 de Arenito Silicificado}

O conjunto 6 é composto por lascas $50 \%$ e fragmentos de lasca $50 \%$, classificadas em simples $40 \%$ e de preparo/acabamento $60 \%$ (tabelas 78 e 79, APÊNDICE 3), indicando estágio avançado de redução. As margens laterais estimadas mostram uma ruptura importante entre uma etapa de redução focada em fases finais e outra em fase inicial/intermediária, a julgar o tamanho e a largura das peças, caracterizando microsequências de lascamento.

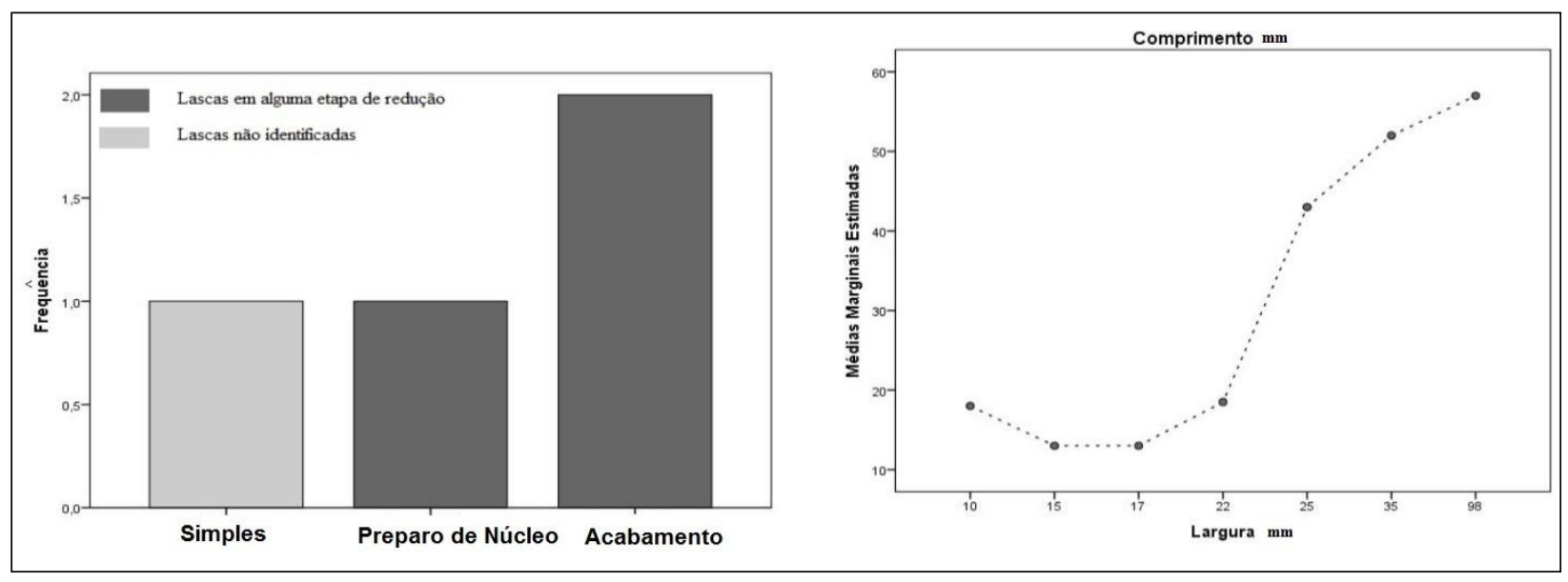

Figura 52 - Frequência e média marginal (mm) C6 arenito silicificado.

Trata-se de um conjunto formado por traços de redução de um bloco $100 \%$, sem presença de córtex 100\% (tabelas 76 e 77, APÊNDICE 3), em que percebe-se o uso de percussão direta e ausência de preparo de talão 100\% (tabelas 80, 81, APÊNDICE 3), com uma ou duas retiradas na face externa $80 \%$. Além disso, apresenta talões lisos $80 \%$ e menos espessos que a média geral $(4,8 \mathrm{~mm})$ e relações entre comprimento, largura e espessura (tabelas 83, 85 e 86, APÊNDICE 3), remetendo à morfologia das lascas quadráticas e globulosas e volumetria adequada ao aproveitamento para a produção de artefatos de detritos descritos como "cassons". 


\subsubsection{Conjunto 7 de Arenito Silicificado}

Conjunto composto por lascas $62,4 \%$, caracterizado por sua distribuição em quase todas as etapas de produção, constituídas pelas de descorticamento $17,5 \%$, de preparo de núcleo $23,8 \%$, de acabamento $23,8 \%$ e de retoque 4,8\% (tabelas 89 e 90, APÊNDICE 3). É formado por certa variabilidade entre o comprimento e largura, de maneira que as margens estimadas indicam resultados de processos de redução, com rupturas e não exatamente sequências.

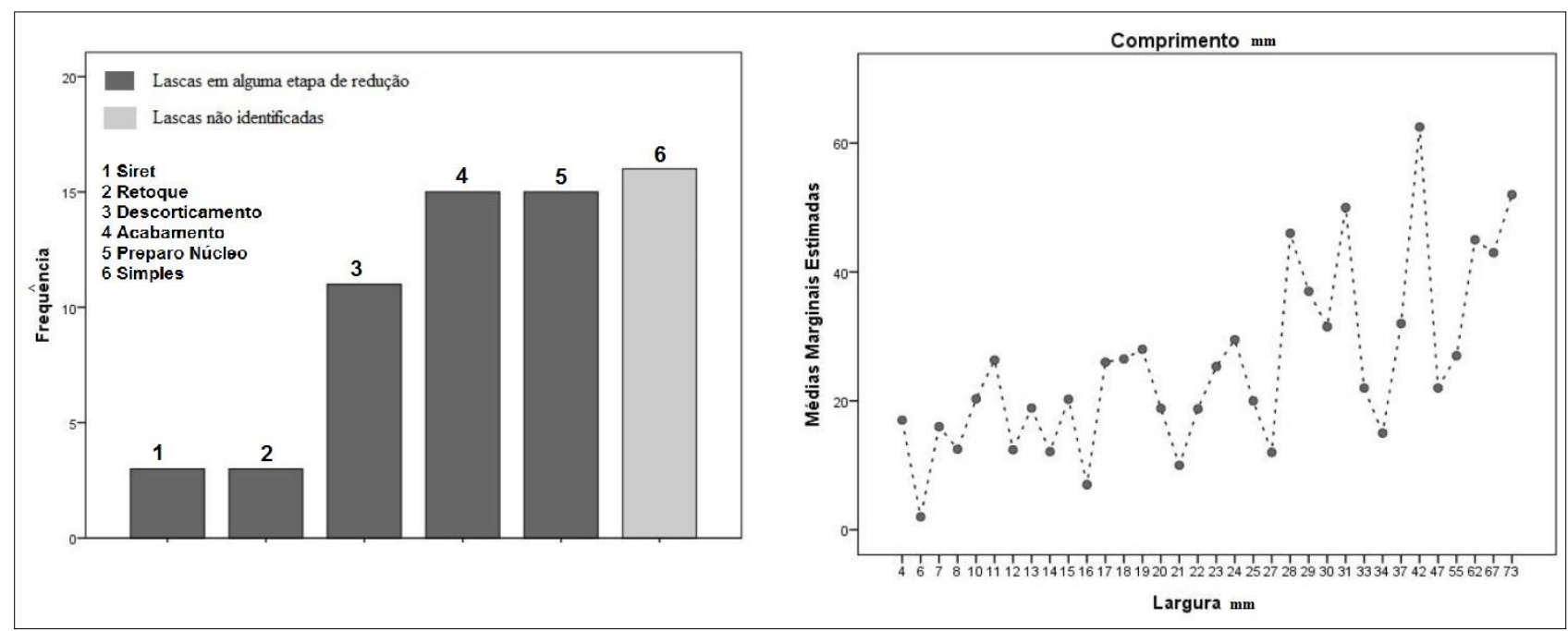

Figura 53 - Frequência e médias marginal (mm) C7 arenito silicificado.

O conjunto é composto por redução executada em bloco 95\%, sem córtex 90,1\% (tabelas 87 e 88, APÊNDICE 3), constituído por lascas de preparo de núcleo 23,8\%, de acabamento 23,8\% e por aquelas consideradas de retoques 4,8\% (tabela 90, APÊNDICE 3), executadas com percussão direta dura 98,4 \% e preparo de talão em 15,9\% (tabelas 91 e 92, APÊNDICE 3), com espessura média de 6,5 mm (tabela 94, APÊNDICE 3), com ângulos que variam entre $80^{\circ}$ a $120^{\circ}$ (tabela 95, APÊNDICE 3). Este conjunto apresenta predominantemente lascas globulosas e preparo da face externa com pequenas retiradas que produz arestas guias. 


\subsubsection{Conjunto 8 de Arenito Silicificado}

O conjunto é constituído por lascas 68,6\% (tabela 100, APÊNDICE 3), podendo ser classificada como de preparo de núcleo 26,6\%, de acabamento/façonnage 26,6\% e de retoque 13,1\% (tabela 101, APÊNDICE 3), apresentando espessuras muito delgadas, desde a espessura de talão, com a média de $4,42 \mathrm{~mm}$, até as medidas de comprimento, largura e espessura das peças que apresentam menos que $25 \mathrm{~mm}$ (tabelas 105, 108, APÊNDICE 3). A análise das médias marginais sugere um padrão de retiradas bastante regular com a sequência de redução focada em suportes muito pequenos ou etapas específicas de lascamento.

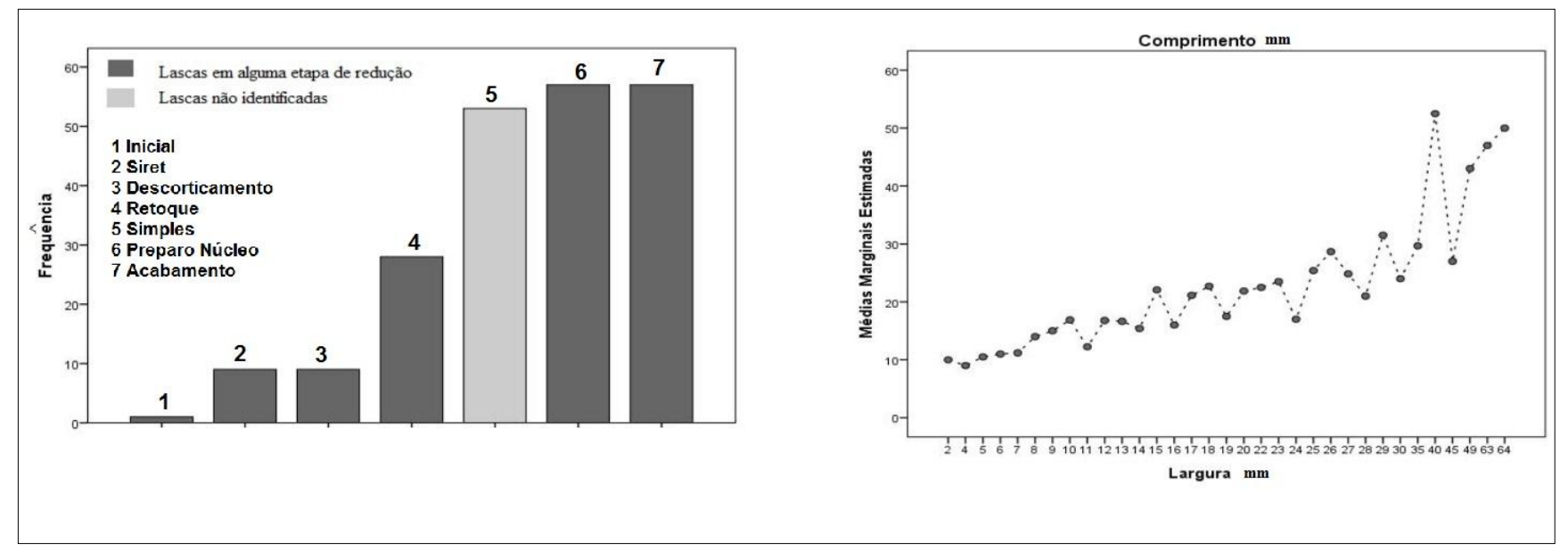

Figura 54 - Frequência e média marginal (mm) C8 arenito silicificado.

Todos os suportes são constituídos por seixos $100 \%$ quase em sua totalidade sem córtex 97,1\% (tabelas 98, 99, APÊNDICE 3). O conjunto é constituído pela debitagem preparada desde etapas de descorticamento, mas concentra-se em etapas intermediárias e/ou finalização de artefatos. A redução destes suportes indica tanto a redução organizada de núcleos quanto um processo subsequente de reestruturação do suporte pela façonnage. Nota-se que apresentam no máximo três lascas, que fazem parte da mesma série de retiradas, e que as técnicas aplicadas dividem-se em três subconjuntos.

O primeiro é formado por lascas com indícios de preparo de superfícies de lascamento levemente alongadas, com aresta guia central e talão liso com formato triangular ou levemente arredondado e indícios de percussão direta com percutor duro 70,6\% e talão liso 65,4\% (tabelas 102, 104, APÊNDICE 3).

O segundo compõe-se de lascas que apresentam indícios de preparo de núcleo, segundo as características facetadas do talão e número de retiradas da face externas das lascas. 
Apresentam indícios de preparo de núcleo, características de preparo do talão 36,4\%, principalmente em relação ao facetado $11,2 \%$ e presença de 3 a 6 retiradas da face externa das lascas 33,7\% (tabelas 101, 103, 107, APÊNDICE 3).

Por fim, o terceiro subconjunto de lascas possui indícios de façonnage 26,6\%, com ponto de impacto difuso ou não identificado $29,4 \%$ e talão linear ou puntiforme que somam 13,1\% (tabelas 101, 102, 104, APÊNDICE 3).

\subsubsection{Conjunto 9 de Arenito Silicificado}

No conjunto 9, as lascas perfazem $58,5 \%$ do total e os fragmentos de lasca $22 \%$, (tabela 111, APÊNDICE 3). A espessura do talão, na média, é de 4,81 mm, e o comprimento 16,9 mm, a largura 14,6 mm, enquanto a espessura e de 5,1 mm (tabelas 116, 119, APÊNDICE 3), mantendo a média de lascas de façonnage e de retoque em seixos pequenos. Estas lascas apresentam um perfil tecnológico muito semelhante entre si, sendo difícil a distinção entre o preparo de núcleo e etapas de façonnage.

Nota-se que as lascas de retoque estão de acordo com a orientação e morfologia dos artefatos, apresentando pouca curvatura e perfil retilíneo, sendo geralmente curtas e de talões lineares e puntiformes. Estas não foram consideradas lascas com a finalidade de modificar a relação volumétrica de um suporte, pois o tamanho e a forma não poderiam representar uma mudança volumétrica expressiva, mas poderiam intervir na modificação marginal de um artefato. 


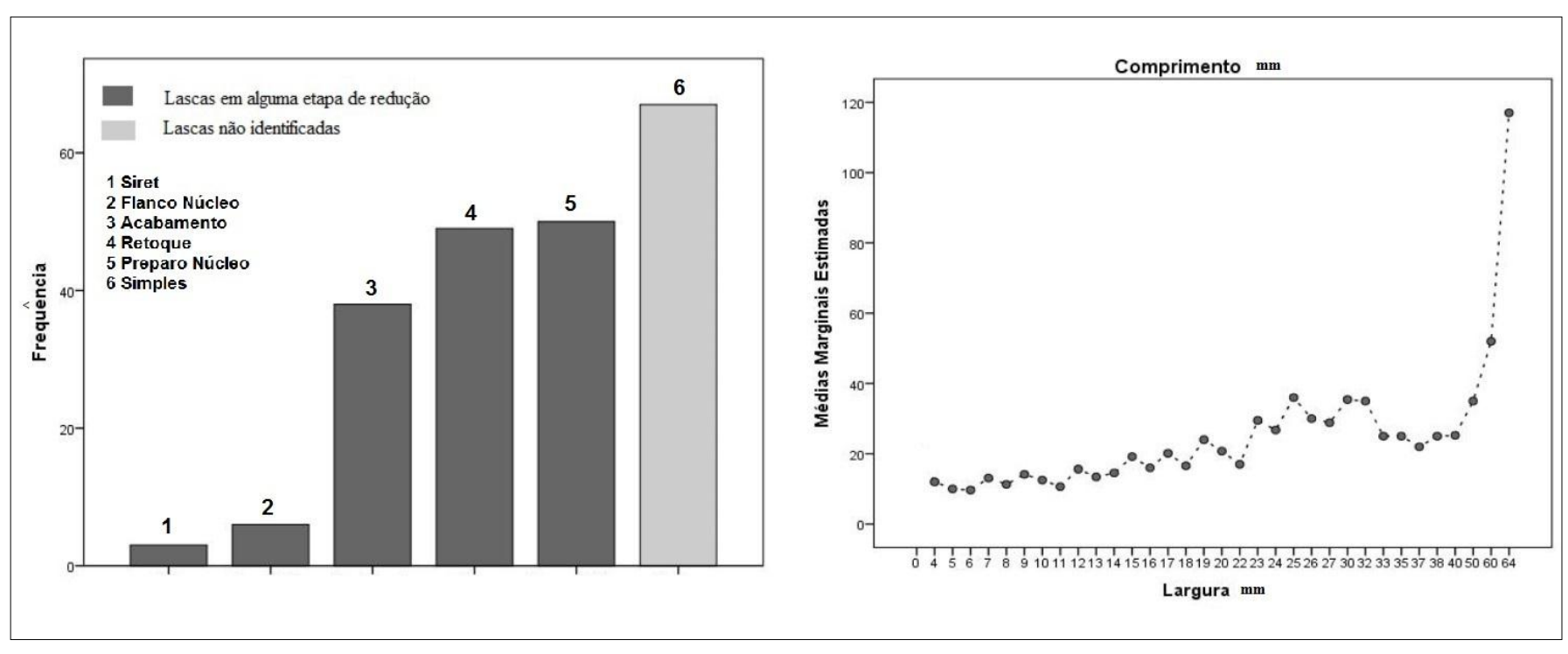

Figura 55 - Frequência e média marginal (mm) C9 arenito silicificado.

O suporte é constituído por seixo em 100\% dos casos, sem córtex 99,2\% (tabelas 109, 110, APÊNDICE 3). A percussão é direta dura 86,4\%, quase sem preparo de talão $80,3 \%$ e predominantemente formada por talões lisos 62,9\%, (tabelas 113, 114 e 115, APÊNDICE 3). Considera-se parte integrante deste perfil, lascas consideradas classificadas como simples 31,5\%, aproximando-se do sistema de debitagem identificado para o conjunto $1 \mathrm{em}$ sílex. Todavia, observa-se o preparo do plano de percussão ao redor do talão, ou na face externa da lasca em contato com o talão. Estas lascas possuem nervura na face externa regularizando os golpes efetuados com indícios de acabamento/ façonnage $17,8 \%$ e retoque $23 \%$ (tabela 112 , APÊNDICE 3). Isso permite alcançar uma lasca com destaque previsível e esmero de produção em relação à parte proximal, indicados pelo preparo de talão $19,7 \%$ (tabela 114 , APÊNDICE 3).

\subsubsection{Conjunto 10 de Arenito Silicificado}

O conjunto 10 é composto por lascas $57,8 \%$ e fragmentos de lasca $21,4 \%$ (tabela 122 , APÊNDICE 3). Destacando-se a preponderância de etapas avançadas de reestruturação (façonnage) e finalização de artefatos representados por lascas de acabamento e retoque $42,3 \%$, e, em menor quantidade, de etapas de preparação de núcleos $14,4 \%$, e de lascas simples sem regularização da face externa ou estigma específico de lascamento 36,9\%, (tabela 123, APÊNDICE 3). A análise das médias marginais sugere etapas de redução focadas em 
certa proporcionalidade entre comprimento e largura, embora, lascas com uma razão maior entre comprimento e largura, estejam presentes.

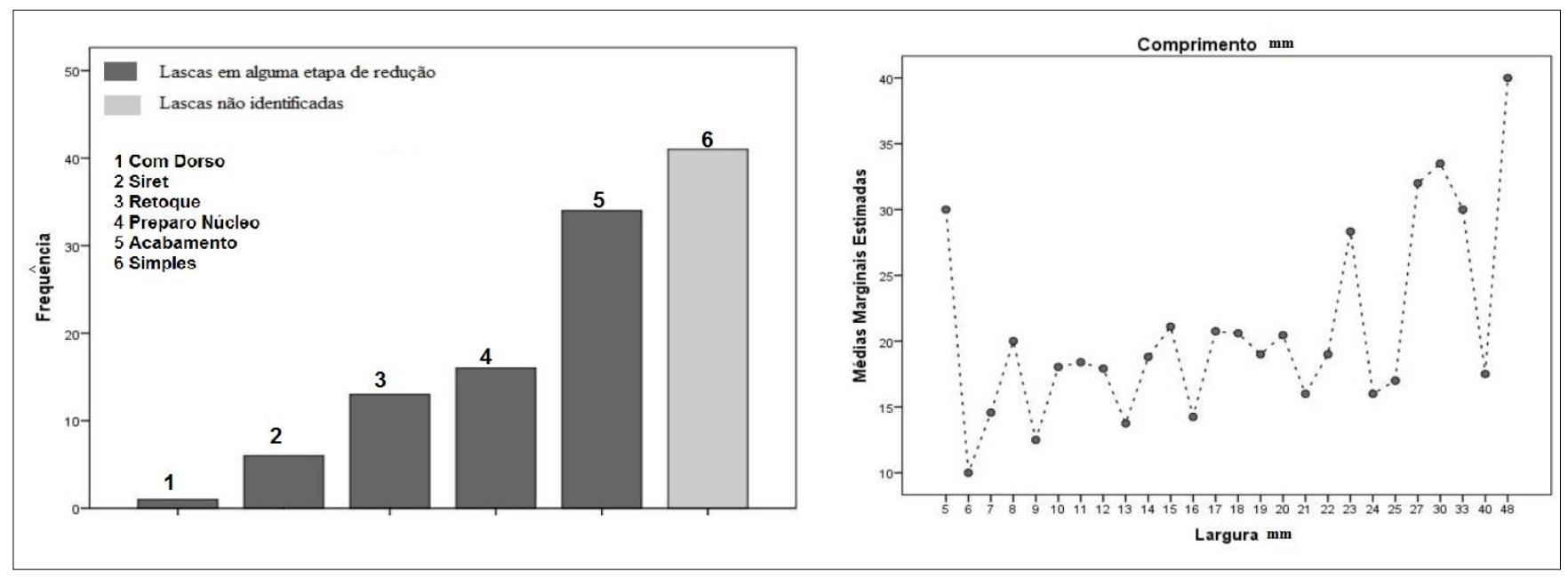

Figura 56- Frequência e médias marginal C10 arenito silicificado.

Na maioria dos casos, as peças não apresentam superfície cortical (tabelas 121 e 122, APÊNDICE 3), destacando-se a preponderância de etapas avançadas de finalização de artefatos. Os talões são predominantemente lisos $71,2 \%$, a percussão é representativamente direta dura 79,3\%, notando-se o preparo de talão presente em 40,5\% dos casos, enquanto os ângulos de talão variam entre $80^{\circ}$ a $120^{\circ}$, sendo a espessura de talão condizente com outros conjuntos em arenito silicificado fino 4,29 mm (tabelas 124, 125, 126, 127 e 128, APÊNDICE $3)$.

Destaca-se que lascas de preparo de núcleo é a minoria, mas é possível verificar que suportes muito pequenos estão sendo reduzidos de forma controlada, de modo que lascas de preparo exibem em sua face externa, concavidade, como se uma lasca preparada tivesse sido destacada desta localidade. Detecta-se também que há a presença de lascas muito delgadas que formam a mesma concavidade na face externa, de modo a produzir uma "canaleta", muito fina. A face externa da lasca é elaborada com retiradas que visam adelgaçar o talão e raramente apresentam o indicativo de preparo de uma aresta guia central. As etapas de acabamento/façonnage de artefato representam $30,6 \%$, enquanto de retoques e ou finalização de artefatos 11,7\% (tabela 123, APÊNDICE 3). 


\subsubsection{Conjunto 11 de Arenito Silicificado}

Este conjunto reúne lascas 58,1\%, descorticadas em 94,4\% dos casos (tabela 132 e 133, APÊNDICE 3), consideradas simples 26,9\%, cuja face externa não há a presença de nervuras. Também estão presentes lascas de preparo de núcleo 32,2\% e acabamento $23,7 \%$ (tabela 134, APÊNDICE 3), focando-se em um processo de etapas de debitagem avançada e de estruturação de artefatos. A relação estabelecida para o comprimento e a largura é condizente com a relação estabelecida para outros conjuntos de arenito silicificado de granulação mais fina apresentados anteriormente em que a relação entre comprimento e largura indica suportes pequenos e em fase de façonnage ou finalização de artefatos.

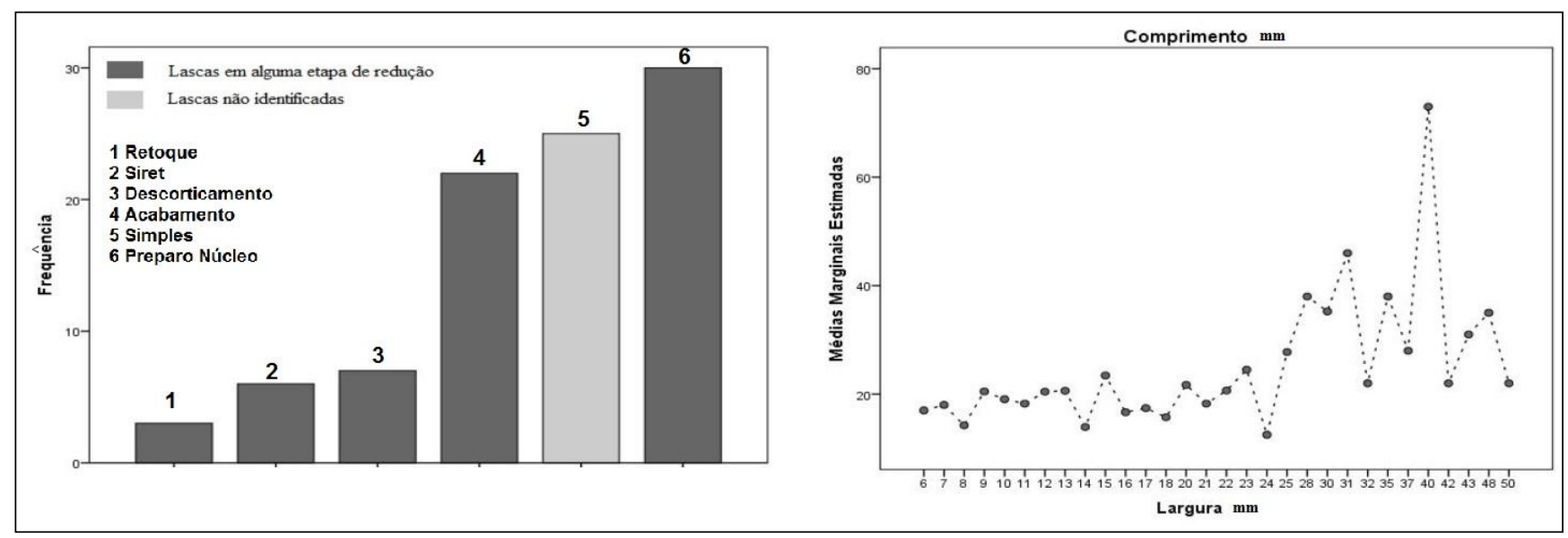

Figura 57- Frequência das média marginal (mm) C11 arenito silicificado.

A percussão aplicada é predominantemente direta dura 88,2\%, sem preparo de talão em 61,3\%, os quais são lisos em sua maioria 66,7\% (tabelas, 135, 136 e 137, APÊNDICE 3). Os ângulos variam entre $70^{\circ}$ a $120^{\circ}$ graus e a espessura do talão apresenta média um pouco superior aos outros conjuntos $5,16 \mathrm{~mm}$, enquanto o número de negativos de retiradas na face externa das lascas apresenta majoritariamente no máximo três retiradas 83,9\% (tabelas 138, 149, APÊNDICE 3).

O conjunto é formado por dois tipos de reduções técnicas. A primeira refere-se ao sistema de façonnage, já descrito para outros conjuntos, cujo sistema de operações técnicas é direcionado para a intenção de modular o volume das formas acabamento-façonnage 23,7\% e de retoque 3,2\% (Tabela 134, APÊNDICE 3). Conforme o perfil das lascas e do preparo do talão, aventa-se a possibilidade de finalização ou reparo de artefatos com indícios de redução bifacial, compostos por lascas com indícios de preparo de superfícies levemente alongadas, 
aresta guia central, indícios de percussão direta com uso de percutor duro 88,2\% e presença de talão liso 66,7\% (tabelas 135, 136, 137, APÊNDICE 3).

O segundo tipo de reduções técnica apresenta indícios de preparo da superfície superior da lasca para a obtenção de uma lasca pequena, relativamente espessa, retirada por percussão direta dura, com orientações de retiradas centrípetas na face externa, produzindo aresta guia e remetendo a um sistema de redução similar aos descritos para planos convexos.

\subsubsection{Conjunto 12 de Arenito Silicificado}

O último conjunto desta série é composto por lascas $45 \%$ e alto índice de fragmentos 41,6\%, sendo grande a presença de peças com córtex 36,1\% (tabelas 142, 143 e 144, APÊNDICE 3). Prevalecem as lascas simples $34,1 \%$, as lascas iniciais e de descorticamento $24,2 \%$ e de preparo de núcleo $20,9 \%$ com a presença de talões corticais $27,5 \%$ e lisos $59,3 \%$ e a presença de apenas 1 retirada da face externa da lasca 63,7\% (tabelas 145, 148 e 151, APÊNDICE 3). As médias marginais apontam para a distribuição de lascas com diversos tamanhos e comprimentos, mantendo parcialmente a correlação crescente entre ambos, apontando que etapas diferentes estão presentes neste conjunto.
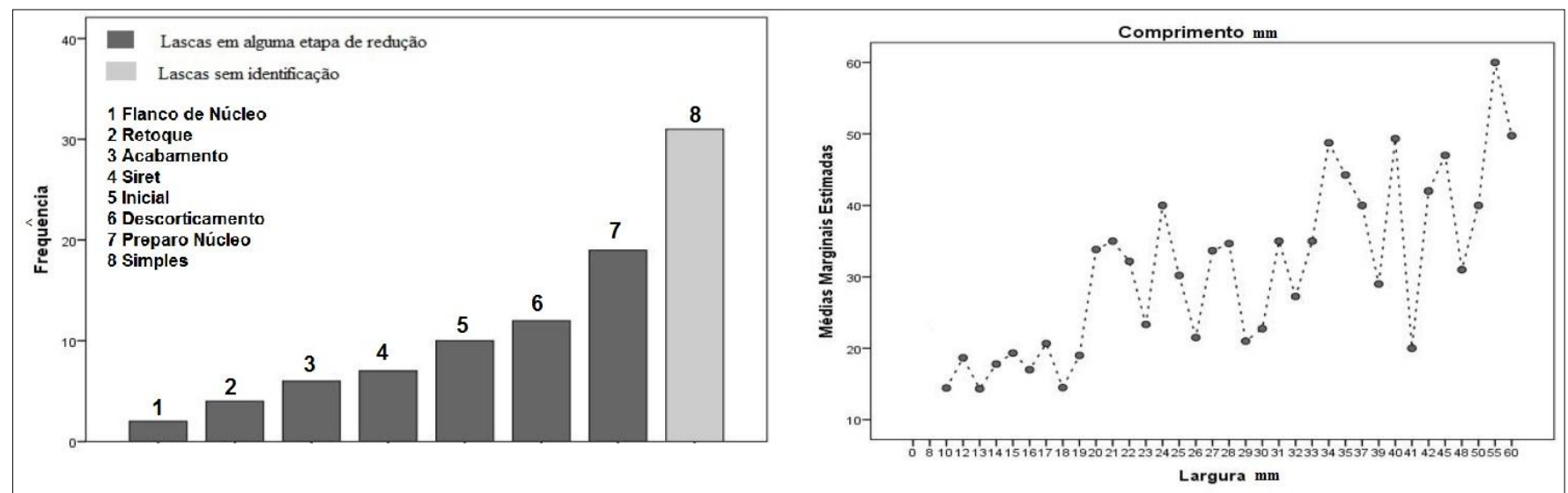

Figura 58 - Frequência e média marginal (mm) C12 arenito silicificado. 
A percussão é direta dura em $95,6 \%$ dos casos e os talões são lisos $59,3 \%$, corticais $27,5 \%$ e outros tipos existem em menor quantidade 12,1\% (tabela 145, 146, ANEXO 3). A espessura do talão é um pouco maior que a média para seixos de arenito fino $(6,49 \mathrm{~mm})$ (tabela 149, APÊNDICE 3) e concernem às lascas de no máximo três negativos de retiradas na face externa (tabela 151, APÊNDICE 3), mantendo um padrão de redução condizente com arenitos de grossa granulometria.

Este conjunto comporta um tipo de debitagem que se aproxima da fatiagem de seixo, observando-se a retirada de lascas espessas em fase de descorticamento, cuja redução não parece ir além. É possível também observar controles diferenciados neste tipo de redução, desde a retirada de lascas espessas e obtusas até níveis de elaboração em que se busca por lascas delgadas, cujo controle da espessura é buscado desde o início da redução.

\subsubsection{Conjunto 1 de Rocha Verde}

A maioria dos suportes são compostos por blocos 72,7\%, sem córtex 87,6\% (tabelas 153 e 154, APÊNDICE 3). As classes mais representativas são fragmentos 42,1\%, seguidos por lascas 33,5\% (tabela 155, APÊNDICE 3). Dentre as lascas, a maioria não possui estigmas de lascamento que as aloquem em etapas especificas da cadeia operatória 45,7\%. Já as que puderam ser alocadas em alguma etapa da cadeia operatória, sugerem a presença de pouco descorticamento 15,7\%, se aproveitamento das arestas guias naturais dos blocos (tabela 156, APÊNDICE 3).

Apesar disso, percebe-se um trabalho de façonnage 11,4\% através da observação do comprimento, adelgaçamento e curvatura da lasca e por meio do exame da porção distal de um gume polido, que apresenta indícios de uma série de retiradas, visando tornar mais delgada a face interna e externa, de modo que aventa-se que o processo de reavivagem seja frequente. As médias marginais estimadas sugerem que se trata de lascas quadráticas, com proporcionalidade entre comprimento e largura, sendo mais espessas que a média geral para outros materiais, apresentando também talões mais espessos (tabela 163, APÊNDICE 3). 


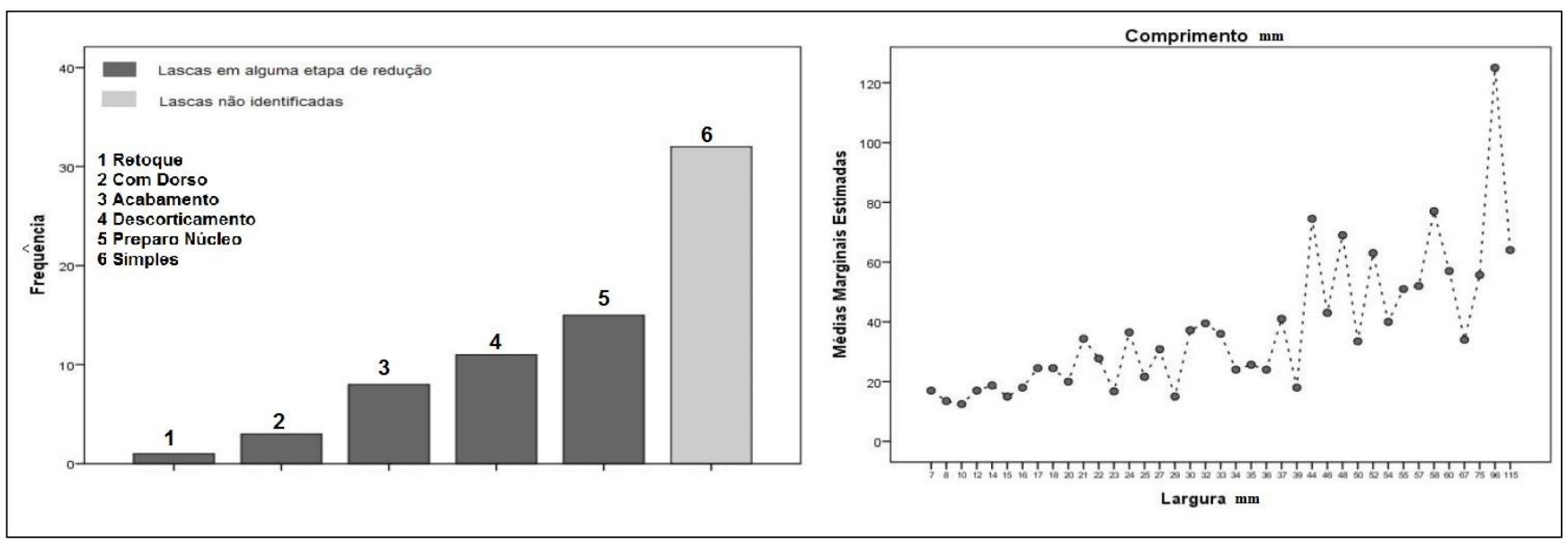

Figura 59 - Frequência e média marginais (mm) C1 Rocha Verde.

A percussão direta dura prevalece em $70 \%$ das lascas que apresentam talão liso $81,4 \%$ (tabelas 157, 159, APÊNDICE 3) e sem nenhum preparo especial (tabelas 158 e 159, APÊNDICE 3). A inclinação do ângulo de remoção refere-se a uma distribuição entre ângulos de $80^{\circ}$ até $120^{\circ}$ (tabela 161, APÊNDICE 3). Nesse tipo de lasca prevalece o baixo número de retiradas da sua face externa, de modo que 1 e 2 retiradas perfazem $71,4 \%$ dos casos (tabela 162, APÊNDICE 3).

Os blocos reduzidos apresentam sinais de lascamento e não apenas do desbastamento de blocos maciços. Assim revelam as primeiras etapas da cadeia operatória, assim consideradas o descorticamento, e, etapas finais, ou de reestruturação volumétrica do artefato (façonnage) sem algum preparo específico de técnicas aplicadas ao talão. A particularidade concerne à presença de fragmentos de gumes polidos 12\% (tabela 155, APÊNDICE 3), e a presença de lascas e fragmentos quadráticos que se apresentam semelhantes quanto ao processo de redução, visto no conjunto 5 de arenito silicificado, em que há alto teor de óxido de ferro.

\subsubsection{Conjunto 1 - Óxido de Ferro $\left(\mathrm{Fe}_{2} \mathrm{O}_{3}\right)$}

O óxido de ferro é um mineral formador de rocha que ocorre em camadas e massas, muitas delas de grandes dimensões, em rochas sedimentares e metamórficas. Comporta três tipos de hematitas, sendo aquela com a qual lidamos a vermelha comum. Sua aparência é maciça, colunar, granular, mamilar, entre outras, enquanto as características de clivagem estão ausentes e concernem a um tipo de fratura subconchoidal, de sistema romboédrico (poliedro de seis faces), com estruturas comumente prismáticas (FERNANDES, 2012, p.174-175), 
apresentando suas propriedades mineralógicas próximas ao quartzo e de outros minerais que compõem tipos variados de rochas verdes, como o grupo dos anfibólios e das olivinas (FERNANDES 2012, p.155-163).

A principal utilização deste material não se volta para um sistema baseado na debitagem ou na façonnage de artefatos, mas na utilização através de quebra e aproveitamento de fragmentos e de pequenas plaquetas ou seixos que representam uma cadeia de preparação curtíssima. O processamento do óxido de ferro fornece pistas sobre como estabelecer assimetrias técnicas a partir do mesmo material. Em síntese, duas ações são praticadas conforme seu uso diferenciado dentro do espaço do abrigo. A primeira ação concerne à quebra e preferência por fragmentos, blocos e plaquetas com formatação quadrática, cujos fragmentos são aproveitados e desgastados no processo de produção de arte rupestre. A segunda ação remete a indícios vestigiais de lascamento classificado majoritariamente como simples e alocam poucas lascas em etapas específicas de lascamento compatível com os conjuntos de sílex e arenito silicificado.

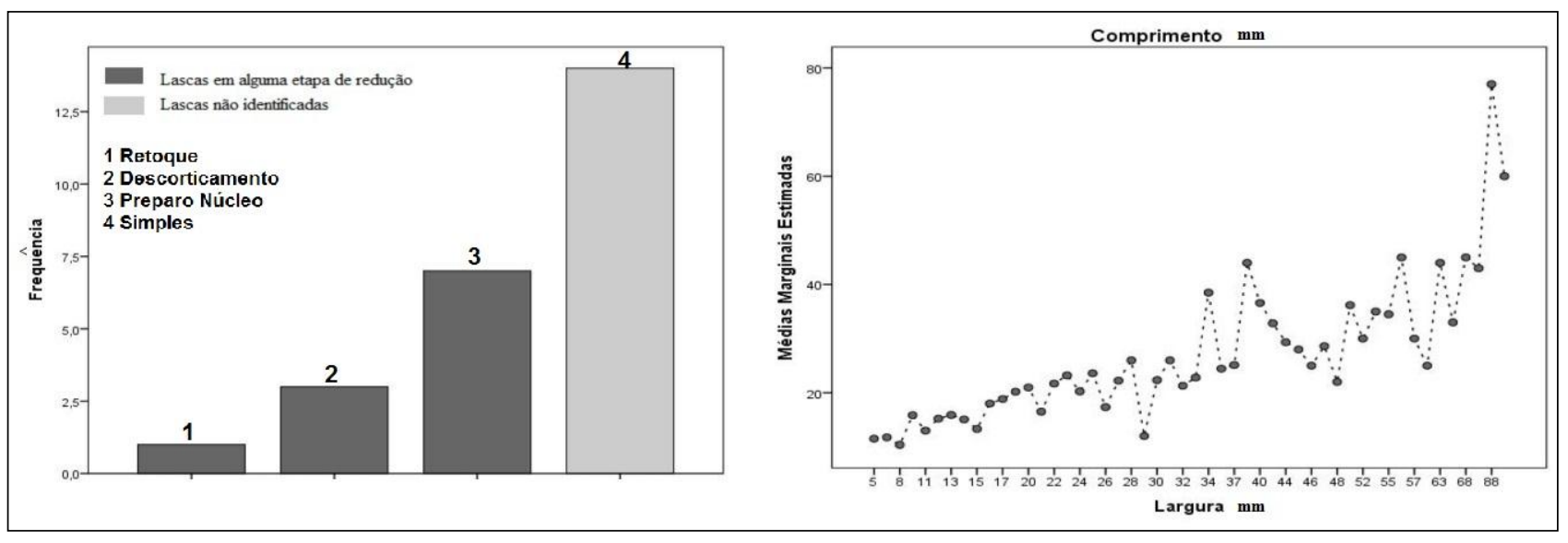

Figura 60 - Frequência e médias marginal (mm) Óxido de Ferro.

Os suportes deste conjunto são compostos por seixos e plaquetas não usadas $56 \%$, enquanto lascas perfazem apenas 7,3\% (tabelas 164 e 165, APÊNDICE 3). Todas as lascas apresentam uso de percussão direta dura, com quase ausência de preparo de talão $72 \%$, compostos por talões lisos 76\% (tabelas 167, 168, 169 e 170, APÊNDICE 3). A maior parte foi considerada simples 56\%, enquanto outras somam $16 \%$ da amostra (tabela 169, APÊNDICE 3). As medidas métricas são importantes parâmetros e registram o uso de suportes pequenos ou reduzidos por quebra com aspecto quadrático e espesso (tabela 171, APENNDICE 3). 


\subsection{ANÁLISE ARTEFATUAL}

Considera-se que a produção artefatual de Abrigos Vermelhos é uma atividade paralela ou sobreposta à produção de cadeias operatórias longas, os quais os artefatos provenientes destas cadeias operatórias raramente estão presentes no sítio e são aproveitados seus detritos para a produção artefatual. As ações técnicas que serão descritas expõem o argumento que se relacionam com a transformação em contextos em que ocorre a rápida transformação da matéria-prima, contextos relacionados ao uso do espaço.

A principal característica destes suportes é o aproveitamento das lascas, fragmentos de lascas e fragmentos, somados à utilização de seixos com reserva cortical e características volumétricas desejáveis. Considera-se que os retoques não são os únicos indicativos da produção destes artefatos (FOGAÇA, 2001, p.346) e que embora não tenham seus suportes planejados antecipadamente (FOGAÇA, 2001, p.346, LOURDEAU, 2010, p.50), exibem escolha intencional de detritos com características peculiares que se tornam suportes apropriados para as atividades realizadas.

Detritos são procurados intencionalmente conforme sua forma, tamanho e densidades adequadas e se transformam em artefatos com níveis técnicos diferenciados. A presença de níveis técnicos diferenciados não se reporta à falta de referência ou expertise técnica sobre como produzi-los, mas se estruturam dentro de uma rede de ações na qual o ápice da performance lítica não é buscada, de modo que os artefatos permanecem na maioria dos casos na fase mínima ou intermediária de produção de um modelo pré-definido.

Estas considerações são originárias das observações de 11 conjuntos artefatuais, organizados em função da classificação do suporte utilizado, sendo formulada uma síntese para os procedimentos técnicos que partem do próprio objeto e não de tipologias. Não obstante, selecionamos apenas alguns exemplares reunidos no interior de cada conjunto artefatual como estudo de caso, haja vista a grande variabilidade presente e necessidade de recorte da pesquisa. 


\subsubsection{Conjunto Artefatual 1}

Os suportes são considerados seixos grandes e volumosos inicialmente lascados no sítio, mas provenientes de cascalheiras depositadas por rio de porte considerável (o rio Vermelho), com grande capacidade de transporte. As extremidades demostram marcas de retiradas, batidas e desgaste, indicando que também foram usados como batedores. Apresentam apreensão favorecida da mão no centro da peça e formatos específicos de seixos que remetem à forma retangular.

Este é o início da cadeia operatória, em que massas grandes e volumosas são reduzidas em fragmentos menores, ou pode haver a preservação da relação entre forma e volume correspondente à intenção da pouca transformação, como consta em poucas retiradas que formam um gume. Destaca-se retiradas iniciais em uma extremidade do seixo, de modo a produzir um gume semi abruto com a presença de retoques paralelos, descontínuos e côncavos. Na extremidade oposta, a abertura do seixo é realizada a partir da retirada de uma lasca inicial e de retiradas em sequência concêntricas, que avançam sobre a reserva cortical. Sobreposta a elas, há uma série de desgastes produzidos pela utilização desta extremidade, fruto de lançamento sobre uma superfície que mantém marcas de pigmento vermelho.

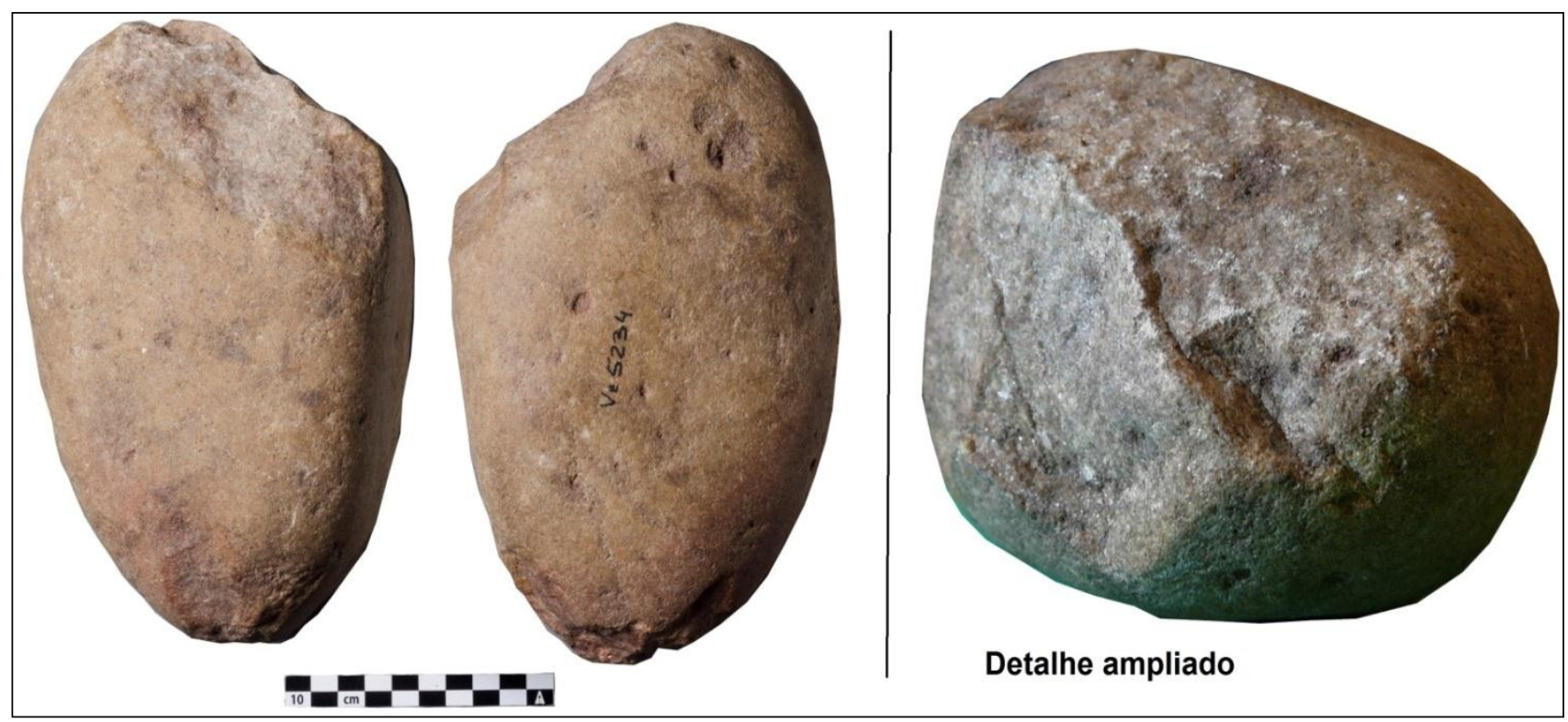

Figura 61 - Artefatos do conjunto 1. Foto - A. Gotardo, 2014. 

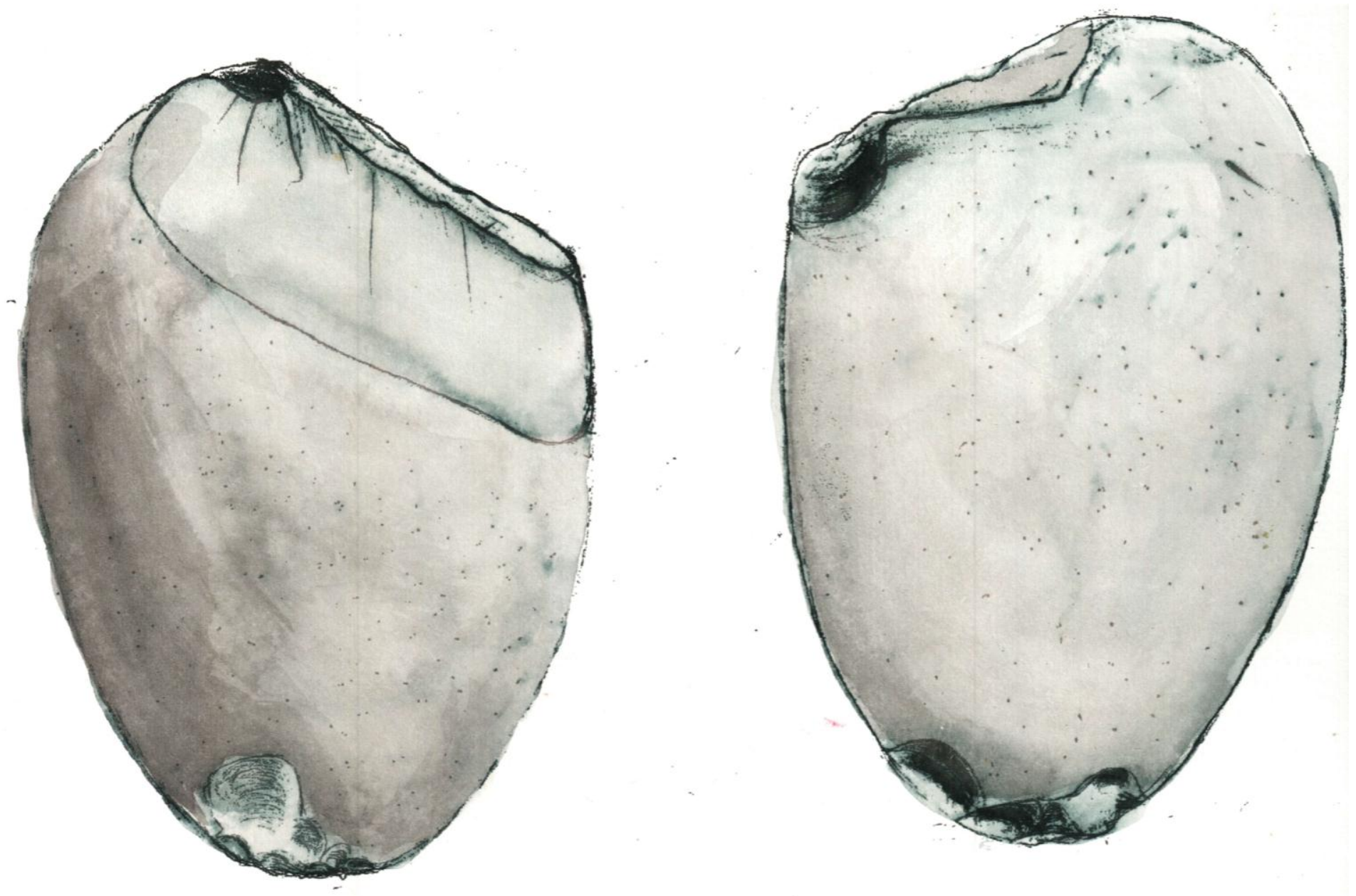

Figura 62 - Desenho de observação: T.Souza. Ilustração: L. Rocco, 2014. 


\subsubsection{Conjunto Artefatual 2}

A este conjunto ocorre o aproveitamento da porção mesial de lascas, com faces de fratura paralelas, provenientes de massas volumosas. Neste processo, massas grandes e volumosas foram reduzidas em fragmentos menores, tornando-se cúbicas, mantendo a proporção entre o comprimento, largura e altura. Podem produzir também fragmentos paralelepipédicos, de modo que duas faces são idênticas e paralelas entre si, sendo aproveitadas como gume. Neste caso, aventa-se o uso da técnica de espatifamento para a redução inicial destas massas volumosas. Assim, seixo, calhau ou blocos são reduzidos por arremesso ou uso de percussão direta com percutores pesados.

Entretanto, é plausível o uso de técnica de arremesso, haja vista que percutores pesados não são notados na indústria. Os planos de fraturas laterais são usados como bordo de preensão para as mãos, enquanto o delineamento do gume é produzido pela façonnage ou a transformação estrutural mais intensa do que o retoque (FOGAÇA, 2001, p.251). Além disso, gera outra camada subsequente de retoques, que delineia uma extremidade distal arredondada. Há variações na estruturação das peças e nos retoques aplicados, sendo, via de regra, subparalelos, curtos e promovidos por entalhes obtidos por um singular golpe (TIXIER et. al., 1992, p. 82). A distribuição dos ângulos de remoção regularmente são abruptos, variando entre $80^{\circ}$ a $90^{\circ}$. 


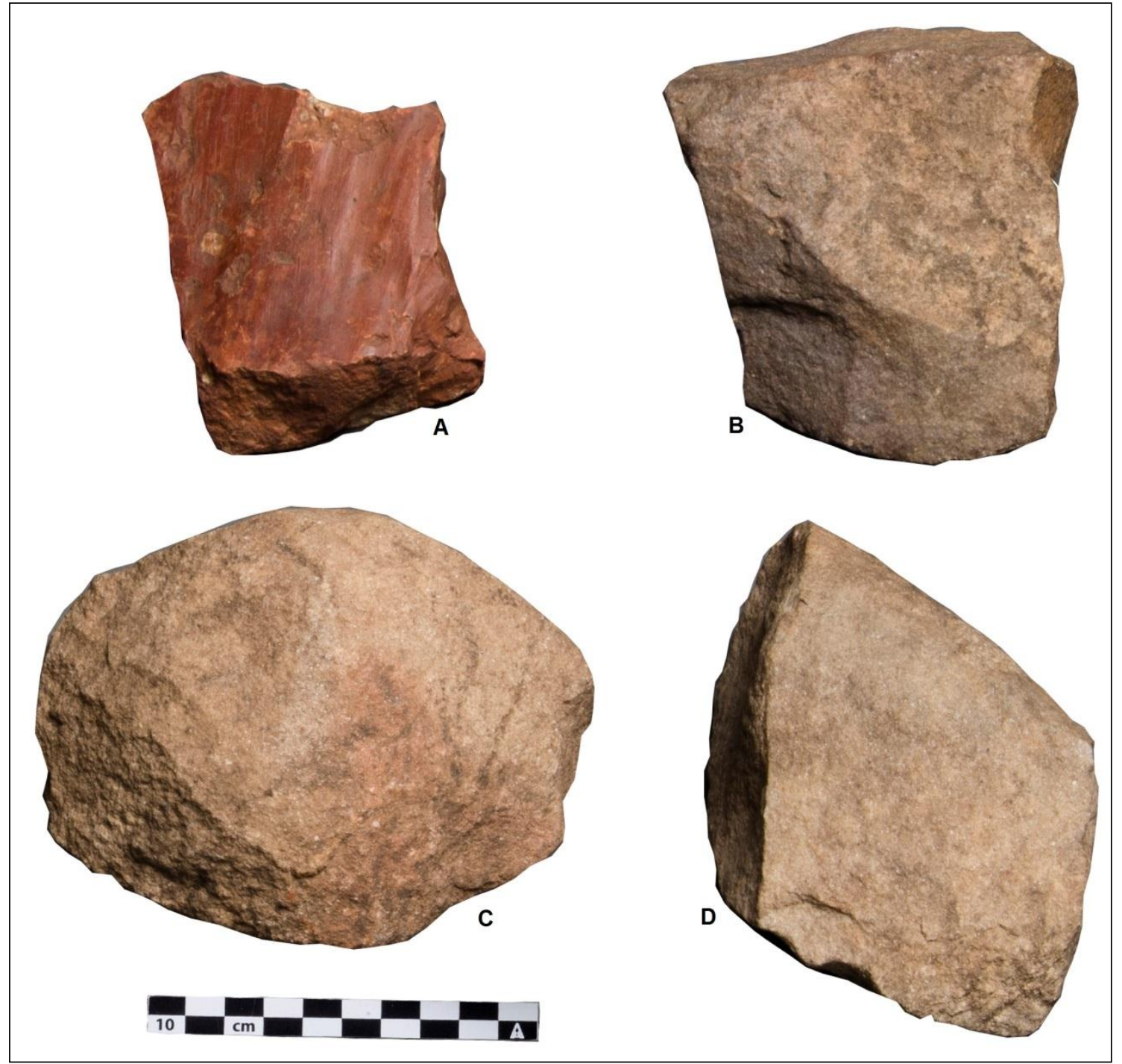

Figura 63 - Artefatos do conjunto 2 . Foto: A. Gotardo, 2014.

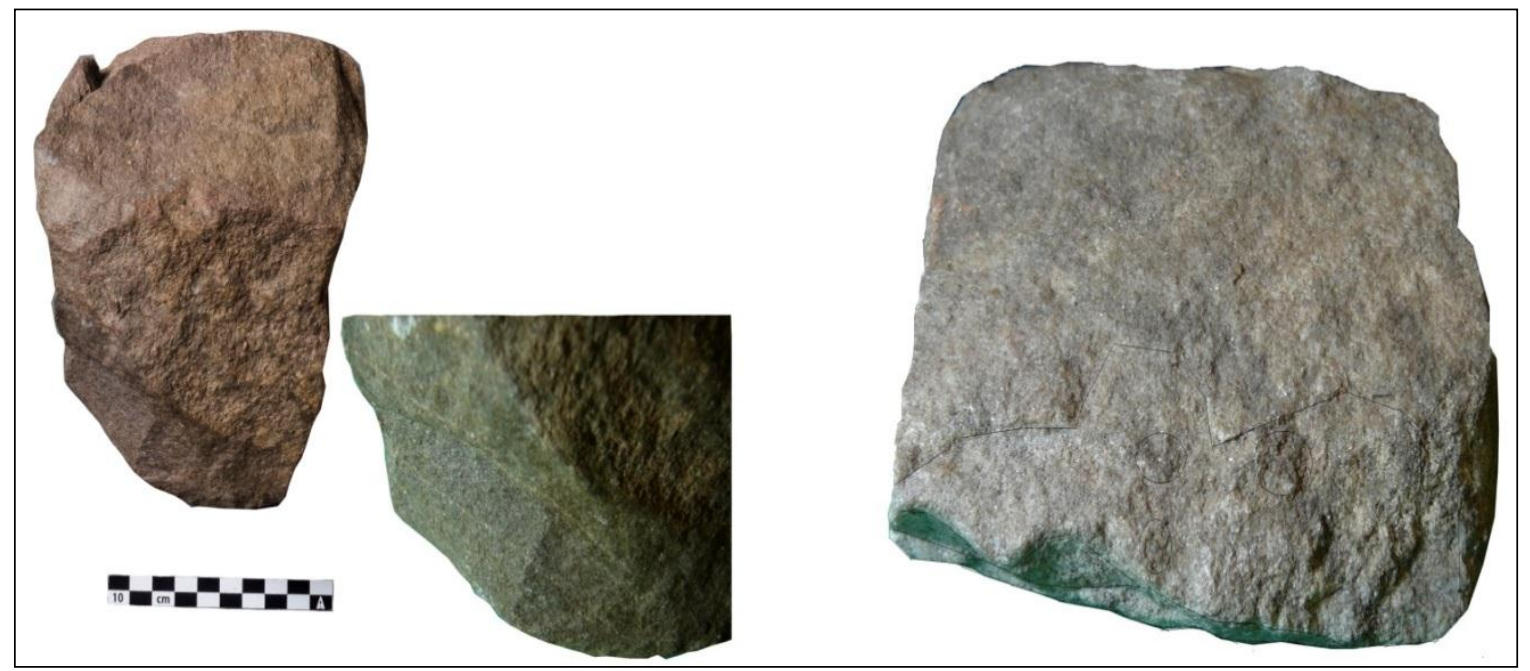

Figura 64 - Detalhes dos gumes de artefatos do conjunto artefatuais 2. Foto: A. Gotardo, 2014. 


\subsubsection{Conjunto artefatual 3}

No conjunto 3 conquanto sinais de espatifamento ainda estejam presentes, os suportes não podem ser identificados, apresentando traços de blocos matriciais, lascas grandes, volumosas, alongadas entre outras características. São fragmentos e detritos de debitagem menores, em etapas de redução mais avançada, talvez, provenientes destes grandes suportes, a julgar a matéria-prima examinada. Há presença de façonnage, seguida por retoques curtos, localizados na porção distal, de aspecto escalariforme. Observa-se a façonnage em algumas áreas do bordo, muitas vezes sobre os retoques em escamas invadentes. A distribuição dos ângulos é composta por ângulos abruptos, variando entre $100^{\circ}$ e $110^{\circ}$. No caso $\mathrm{B}$, os bordos foram retocados em ambas as faces, sugerindo a presença de tratamento bifacial, tendência que não se confirma em peças em arenito grosso recuperadas no sítio.

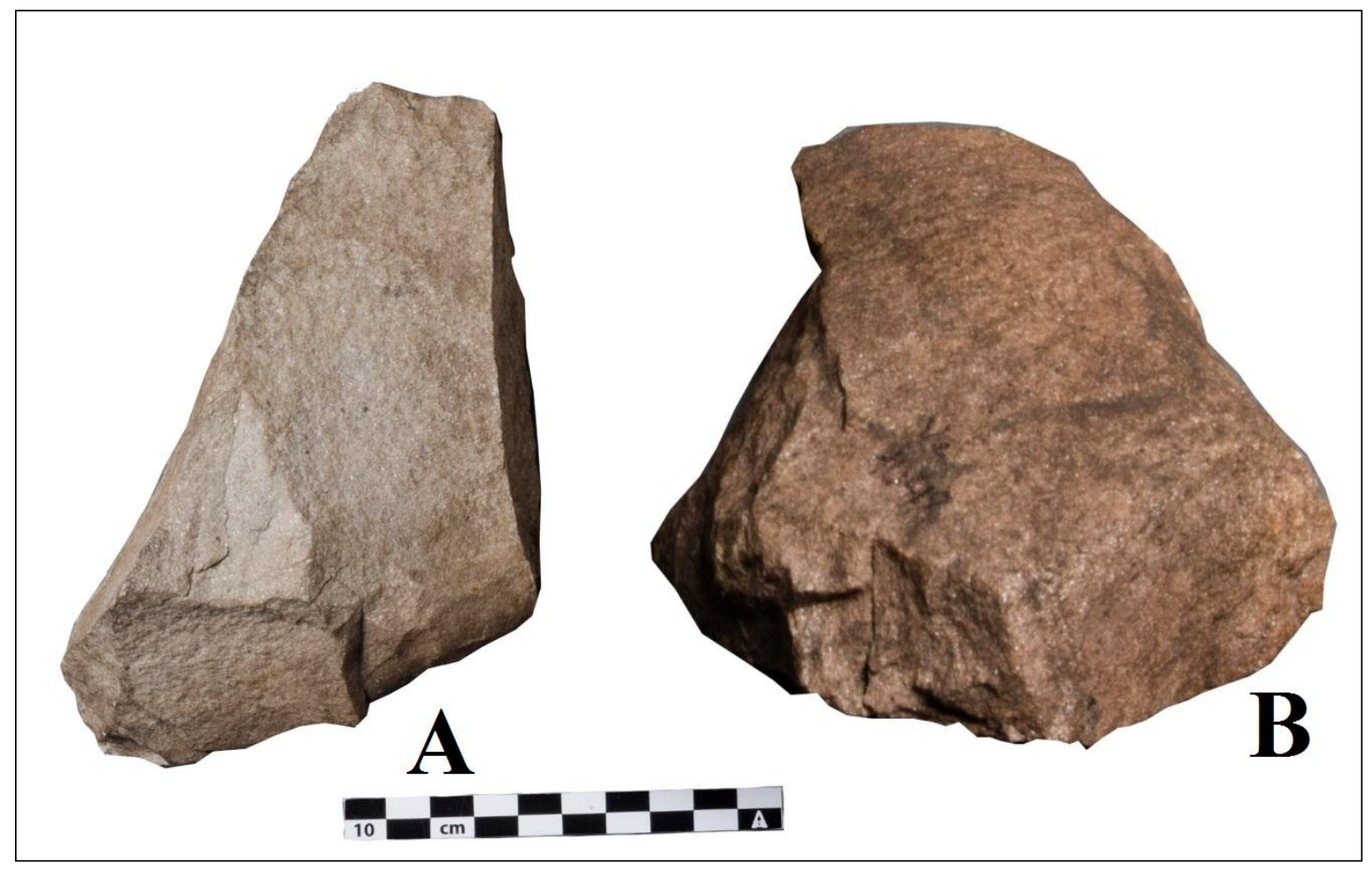

Figura 65 - Artefatos do conjunto 3. Foto: A. Gotardo. 2014. 


\subsubsection{Conjunto artefatual 4}

Constatam-se dois tipos de transformação diferentes em um mesmo tipo de suporte composto por lascas com planos de fraturas laterais. O caso A consiste no aproveitamento de um fragmento de lasca com três faces paralelas e planos de fraturas laterais angulosos. $\mathrm{Na}$ face externa, há a tentativa de elaboração de um único talhe, de modo que a matéria-prima é experimentada por um único retoque localizado ao lado da aresta esquerda da face de fratura. A peça também comporta enrugamento causado por um evidente processo de queima que pode significar o abandono do artefato em fase inicial de transformação.

Já o caso B, reporta-se a uma sequência de redução intencional, evidenciando a existência de uma cadeia operatória de produção de lascas preparadas, deixando séries de negativos sistematicamente paralelos no dorso. Observa-se a formatação de uma crista central e retiradas longas centrípetas na face externa de lascas, reestruturando esta face, seguido por um processo de sobreposição de retoques (entalhe). Há também há trabalho de retoques longos, paralelos e unidirecionais na face interna no lado direito da face interna da lasca, como trabalho de formatação do gume, delineando uma extremidade distal arredondada.

A posição e a localização apontam o delineamento, o ângulo e a morfologia dos retoques esta fosse uma lasca com a face externa preparada no processo de produção da cadeia operatória, sugerindo uma lasca com a face externa preparada e indícios de retiradas da face externa como um princípio regulador da debitagem em um material friável, que sofreu quebra em sua porção mesial, por esta razão, então, sendo reciclada e transformada em artefato com características que remetem a produção de gume arredondado e face externa preparada. 


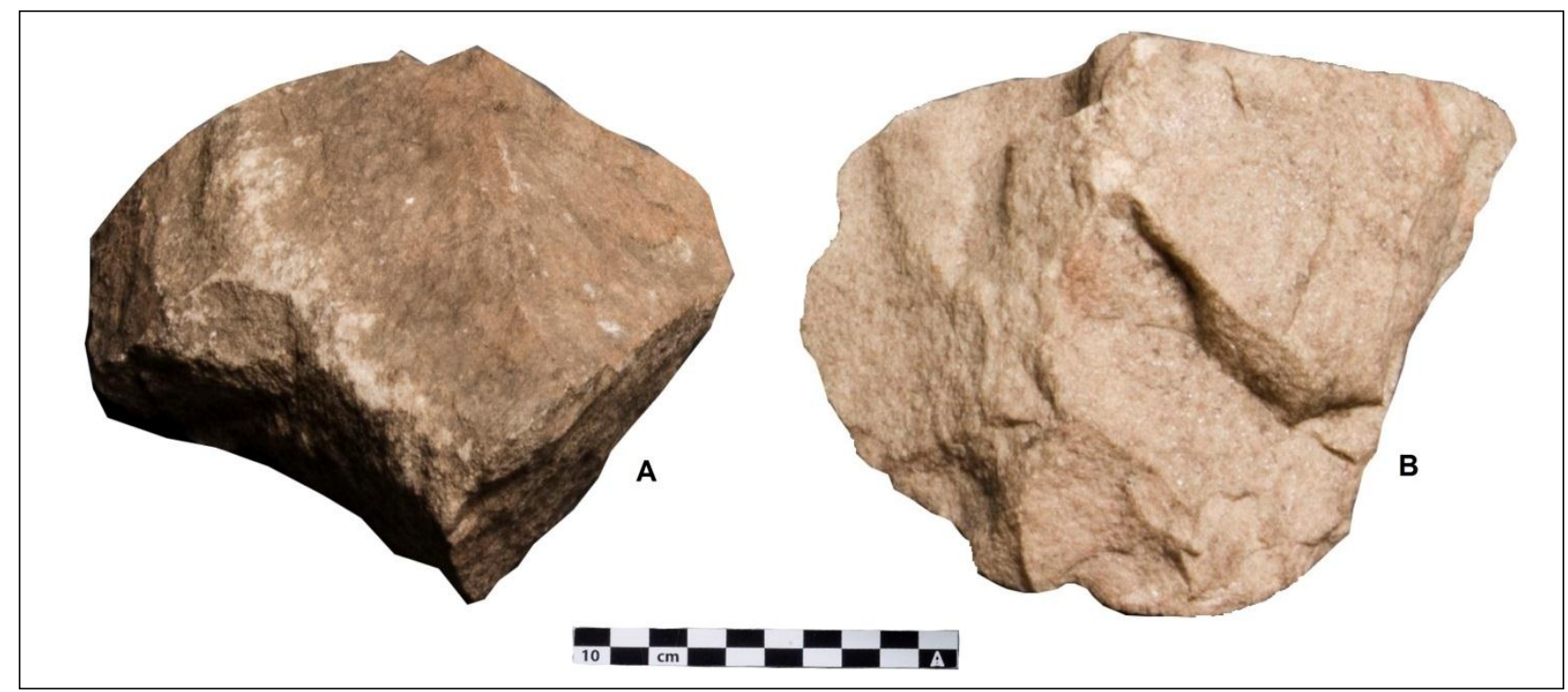

Figura 66 - Artefatos do conjunto 4. Foto: A. Gotardo, 2014. .

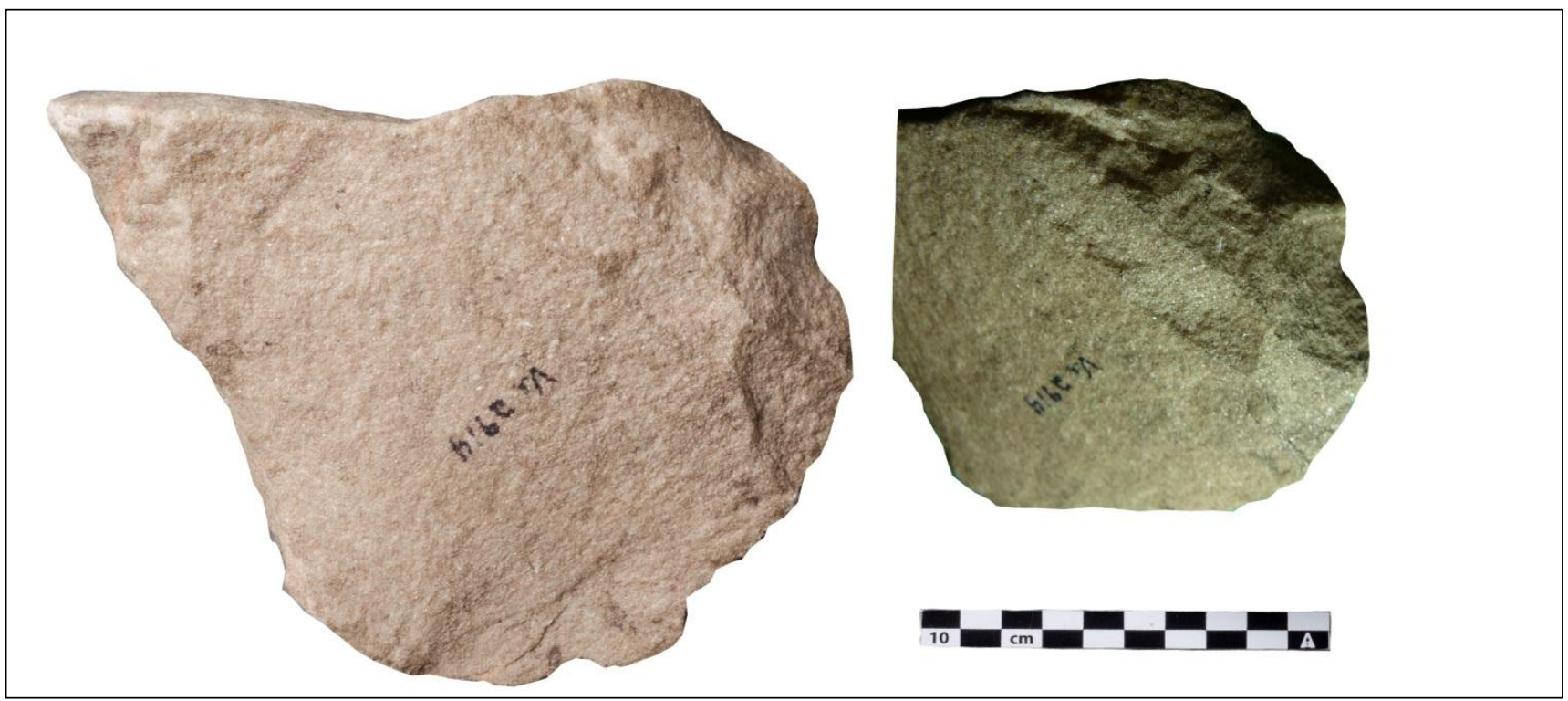

Figura 67 - Detalhes dos retoques do conjunto 4. Foto: A. Gotardo, 2014. 


\subsubsection{Conjunto Artefatual 5}

O conjunto artefatual 5 é formado por suportes compostos por massas volumosas provenientes de etapa de preparação de núcleos. Observa-se que a configuração prismática é frequente, entretanto o nível de transformação técnica é diferenciado e relativo à transformação do bordo. Apresenta dois tipos de transformações. O caso A trata-se de seção prismática, com aproveitamento de três planos de fratura paralelos. A superfície central é paralela à face plana, remetendo a uma forma trapezoidal e produção de bico na porção distal.

O caso B, por sua vez apresenta duas superfícies planas intersectadas por uma nervura central no eixo longitudinal, de modo que a seção transversal é triangular. É possível perceber a eliminação da porção distal e a subsequente transformação desta área por meio de retoques abruptos, além de retoques que apresentam remoções alternadas na face interna e externa dos bordos, transformando-os em gume com delineação arredondada, a qual cria uma linha de entalhes e invasividade dos retoques curtos sem transformação intensiva da face externa. A distribuição dos ângulos reporta-se a ângulos de remoção abruptos em torno de $90^{\circ}$.

De outra forma, os casos C e D, apresentam lascas com negativos na face externa, que remetem a fase de preparação de lascas, porém, encontram-se quebradas, sendo em seguida, executada a transformação ativa do gume, apresentando sequências escalonar de retoques aplicados sobre o bordo. Estes bordos foram retocados em ambas as faces de maneira um tanto irregular, parecendo tratar-se de retrabalhamento. Estas peças indicam que, após, ou concomitante ao espatifamento dos blocos matriciais, procede-se à debitagem de núcleos para as retiradas de lascas grandes e alongadas, as quais podem ser utilizadas como suportes de artefatos unifaciais. A variabilidade angular está em torno de $70^{\circ}$ a $80^{\circ}$, considerados semi abruptos e os retoques são qualificados como totais ao longo do bordo, apresentando entalhes executados na face interna e externa. Por fim, ainda é possível observar a presença de mais dois casos E, e F, que tratam de fragmentos mesiais de lascas em estado adiantado de redução, com a presença de desgaste lateral. 


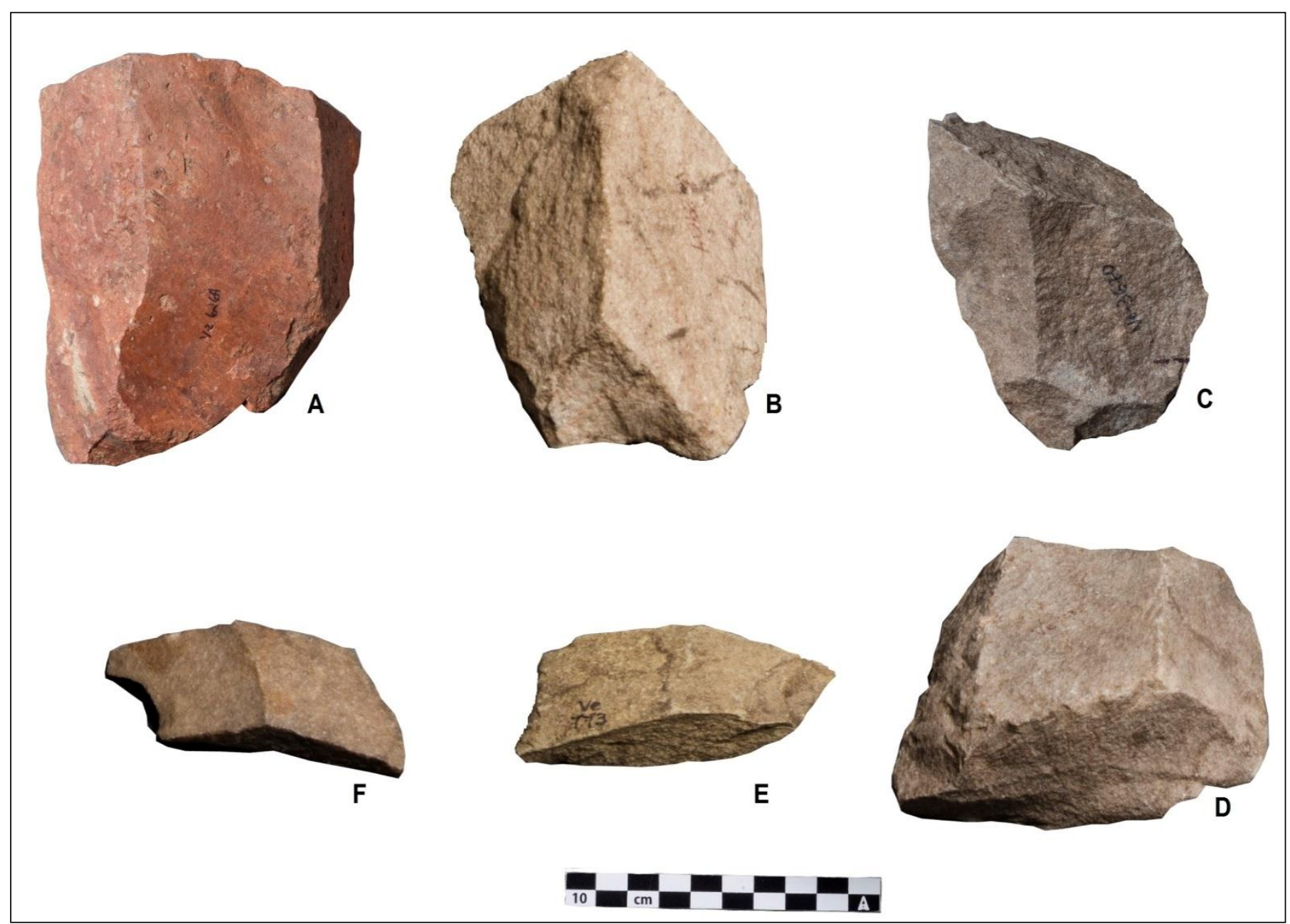

Figura 68 - Artefatos do conjunto 5. Foto: A. Gotardo, 2014.

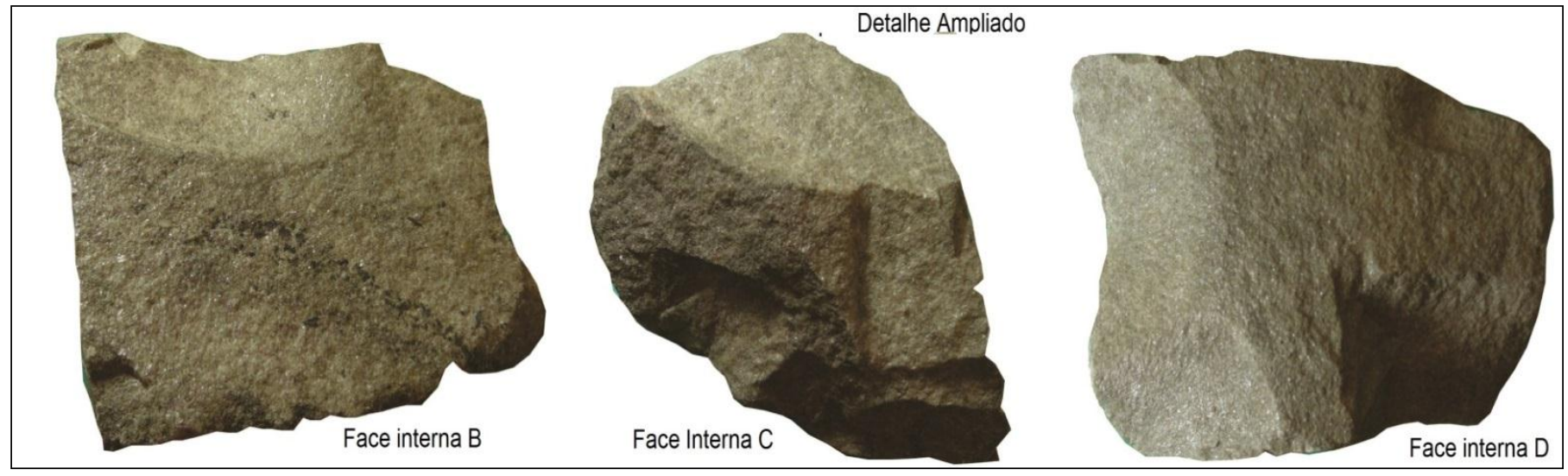

Figura 69 - Face interna dos artefatos B,C,D. Foto: A. Gotardo, 2014. 


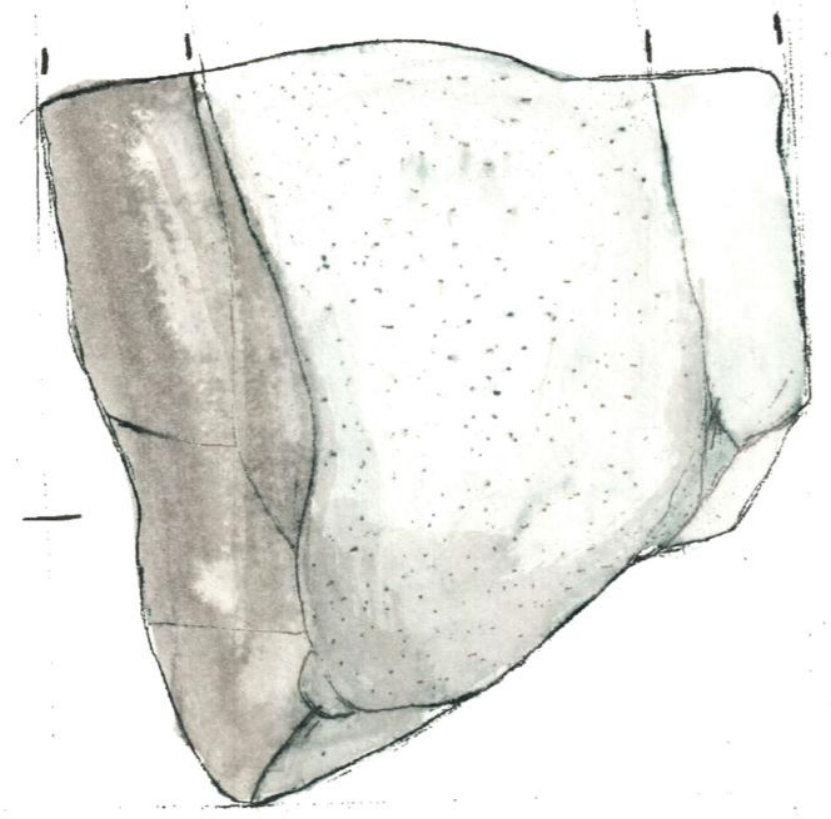

Figura 70- Desenho de observação A - T. Souza. Ilustração: L. Rocco, 2014.
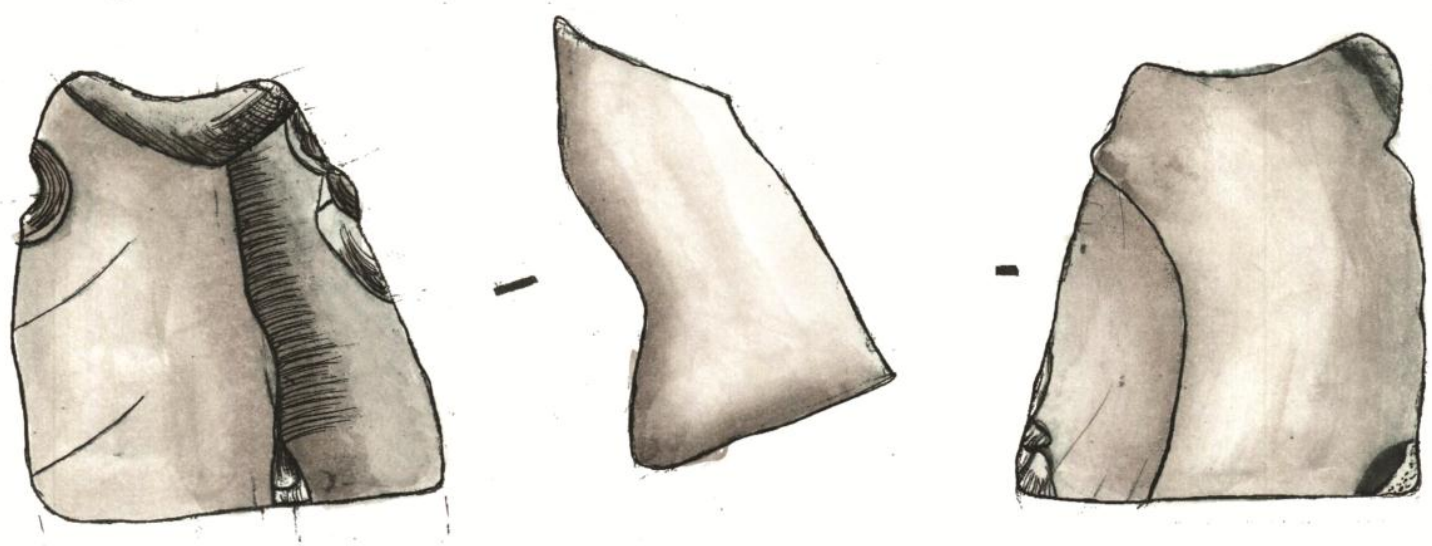

Figura 71 - Desenho de observação B - T.Souza. Ilustração: L.Rocco, 2014. 


\subsubsection{Conjunto artefatual 6}

O suporte deste conjunto é formado por uma elipse ou uma seção plana de um cilindro circular, de onde provém lascas alongadas, compostas por dois bordos ativos longitudinais. É provável que os suportes procurados fossem de grandes dimensões e que estas lascas evidenciem a busca por estes suportes alongados. O caso A consiste em uma lasca espessa com reserva cortical, cujo talão e estigmas de lascamento próximo ao talão foram eliminados, contudo, os ângulos do gume são abruptos, variando entre $90^{\circ}$ a $100^{\circ}$. Há trabalho de façonnage composto por duas sequências sucessivas de retiradas sobre a face externa da lasca. A primeira sequência é composta por uma série de retiradas longas, com provável direção centrípeta, já que a superfície encontra-se bastante alterada pela ação da queima. Observa-se retiradas invasivas e contínuas, contornando toda a extensão centro-esquerda até a extremidade distal, na qual há concavidade acentuada e arredondamento. Na porção centrodireita, por sua vez, não há modificação da face interna, permitindo cogitar a hipótese de que este artefato tenha sido confeccionado e ou usado de maneiras distintas. Dessas, condiz o aproveitamento da porção centro-esquerda, relacionado a uma possível modificação bifacial do gume. A segunda, por sua vez, reporta-se a porção centro-direta, possui aspectos da redução de um artefato plano-convexo.

O caso B tem por objeto uma lasca bipolar, com uma aresta guia central em sentido longitudinal. $\mathrm{O}$ talão mede $18 \mathrm{~mm}$, liso e ângulo do talão com a face interna é de $95^{\circ}$. $\mathrm{O}$ trabalho de façonnage é localizado sobre as arestas guias que foram produzidas na retirada da lasca, ou sobre a face externa da lasca, ou ainda a partir de uma retirada na extremidade proximal do talão, estendendo-se até a porção mesial da face externa. Sobre a face externa, parece ter sido aplicada uma série de retiradas largas de direção centrípeta e sobre as arestas guias produzidas por estas retiradas, há uma série de retoques curtos e escalonados, que visam torná-las convexas. 


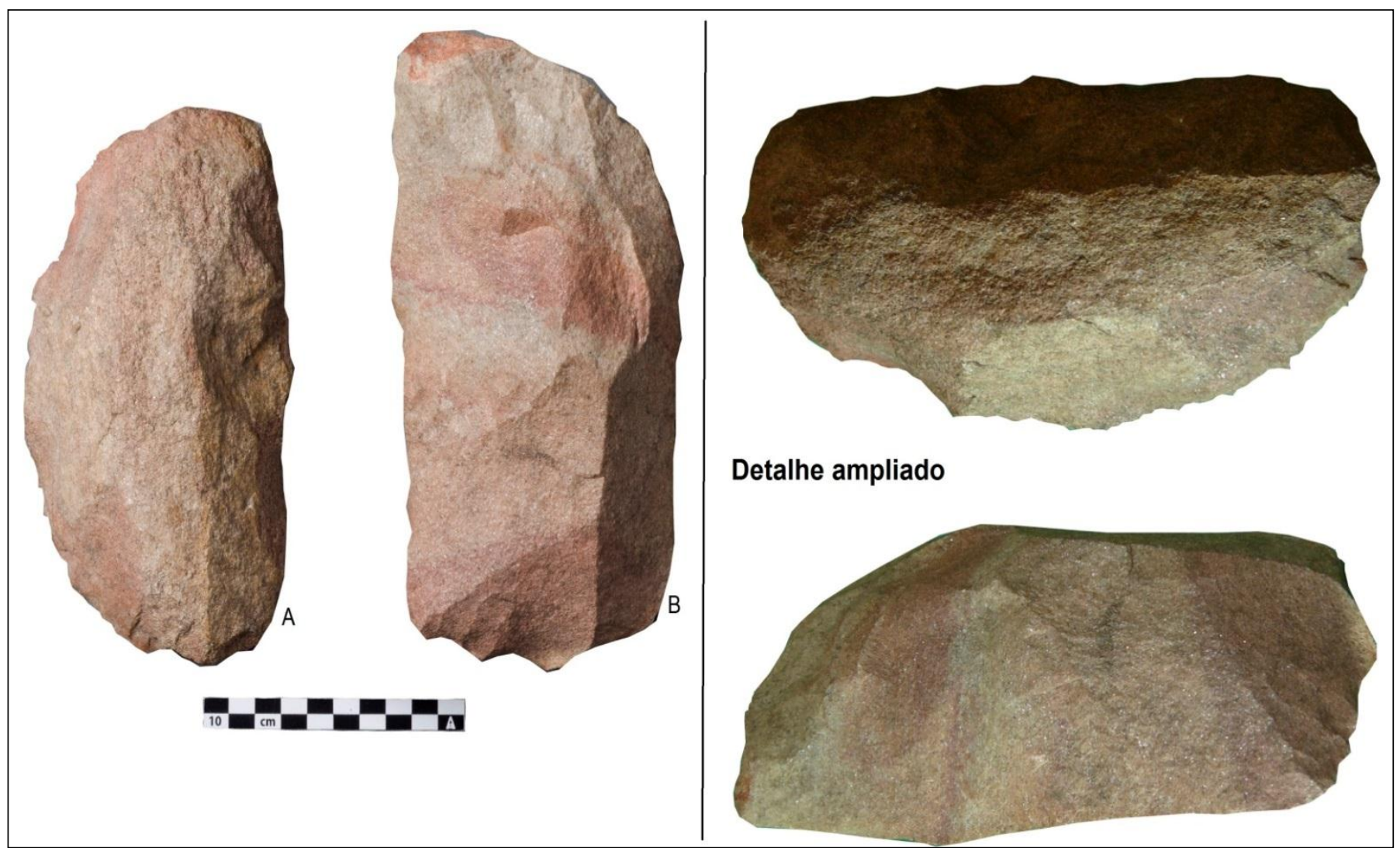

Figura 72 - Artefatos do conjunto 6. Foto: A. Gotardo, 2014.
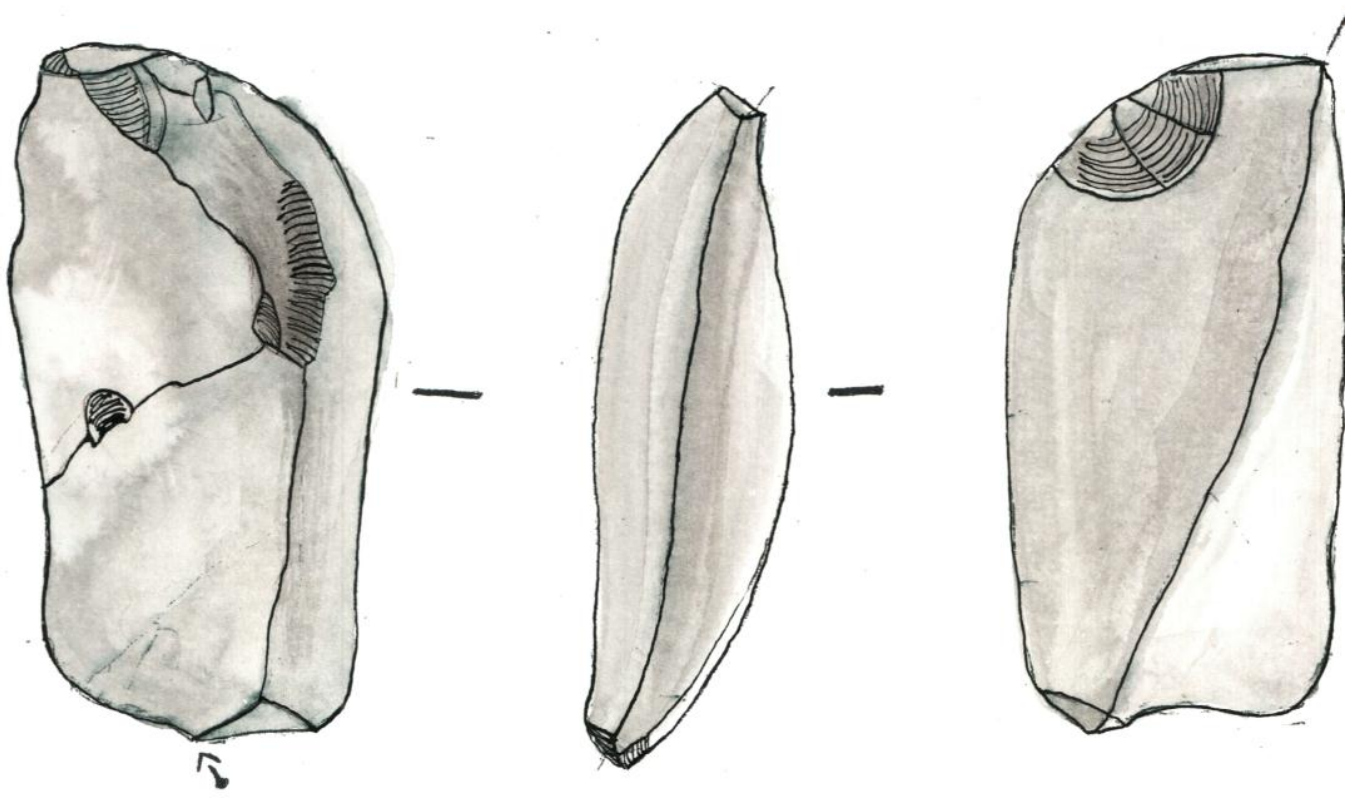

Figura 73 - Desenho de observação A, T.Souza. Ilustração: L.Rocco, 2014. 


\subsubsection{Conjunto 7}

A considerável quantidade de reserva cortical nas peças do conjunto 7 , associada ao pouco rigor formal dos artefatos, indica o uso de lascas de descorticamento e de preparo de núcleo para a produção de utensílios. Os ângulos de gume são semi-abruptos e variam de $90^{\circ}$ a $100^{\circ}$.

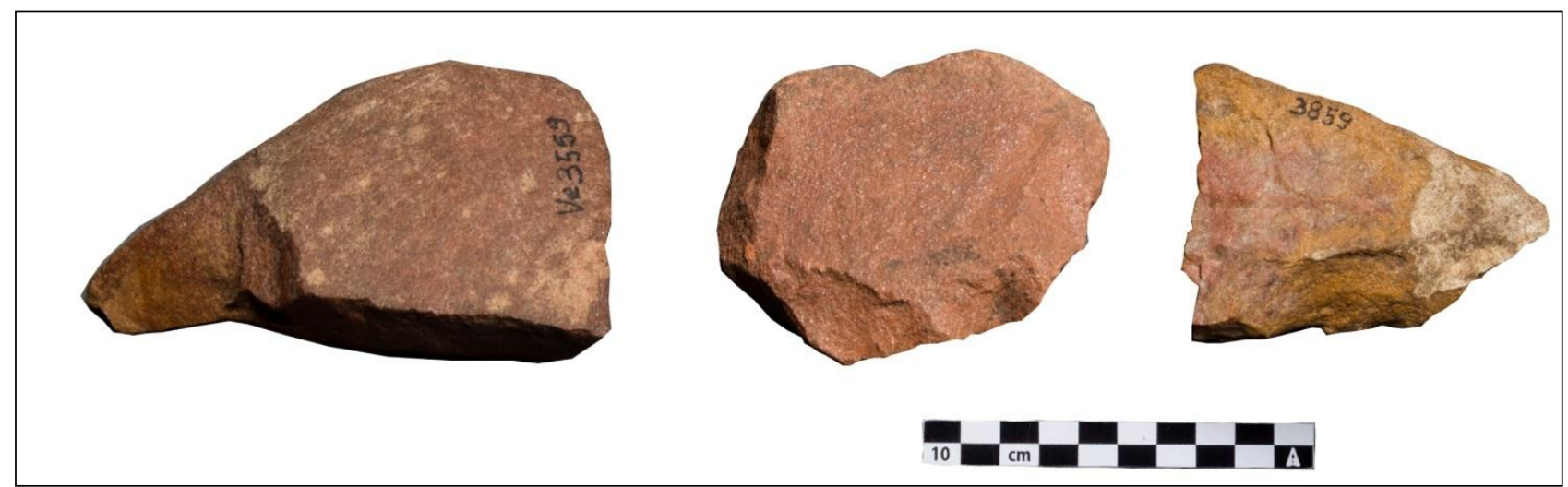

Figura 74 - Artefatos do conjunto 7. Foto: A. Gotardo

\subsubsection{Conjunto Artefatual 8}

Neste conjunto os suportes são caracterizados por seixos pequenos e espessos em fase inicial de redução, com talões de bulbos salientes e ondas de percussão concêntricas bem marcadas, denotando o uso de percutores pesados. A série de retiradas apresenta duas sequências de retoques focados na formatação de design específico. Estas retiradas concernem a uma série de retoques diretos, escalonados, profundos e invadentes, localizados continuamente em toda a extensão de apenas um bordo. Os ângulos de remoção se referem a ângulos abruptos, variando em torno de $110^{\circ}$. Este conjunto indica a variabilidade na formatação dos utensílios, que se utilizam por vezes dos mesmos suportes, no caso, lascas de descorticamento com importante reserva cortical, contudo, com sinal de elaboração em material de melhor qualidade. 


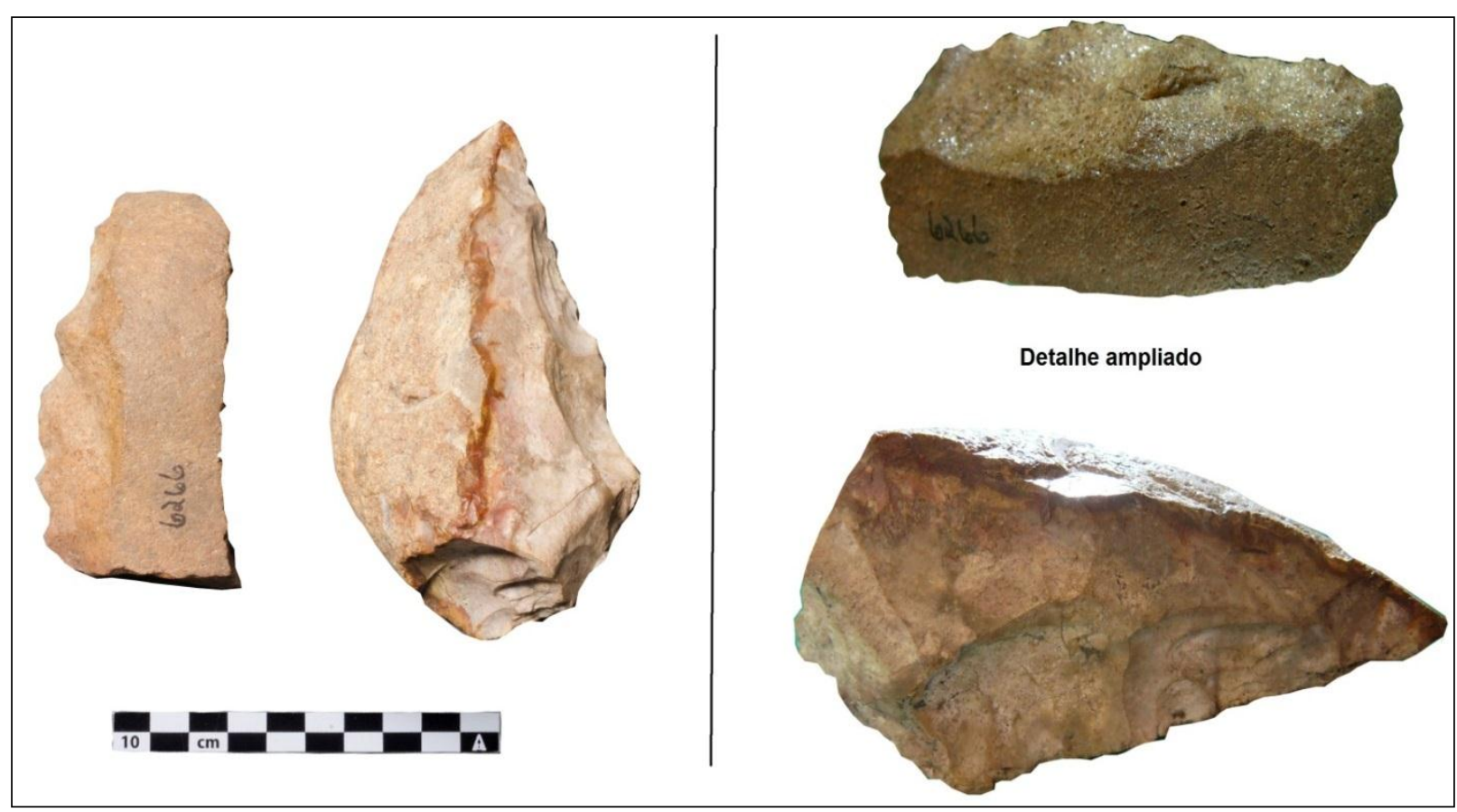

Figura 75 - Artefatos do conjunto 8. Foto A. Gotardo, 2014.

\subsubsection{Conjunto Artefatual 9}

Os suportes são compostos por cassons e espessas lascas corticais que remetem a uma massa volumétrica com pelo menos um par de lados paralelos, sugerindo seção transversa trapezoidal, cuja distribuição dos ângulos de remoção em todas as peças analisadas concerne à variação entre $90^{\circ}$ e $100^{\circ}$. É evidente a existência de uma cadeia operatória, seja na obtenção e tratamento de núcleos, seja na reciclagem de artefatos massivos retocados. Este é o conjunto que mais exemplares apresenta e também níveis de formatação variados que reportam-se à formatação de planos convexos, porém com níveis de elaboração diferenciados. 


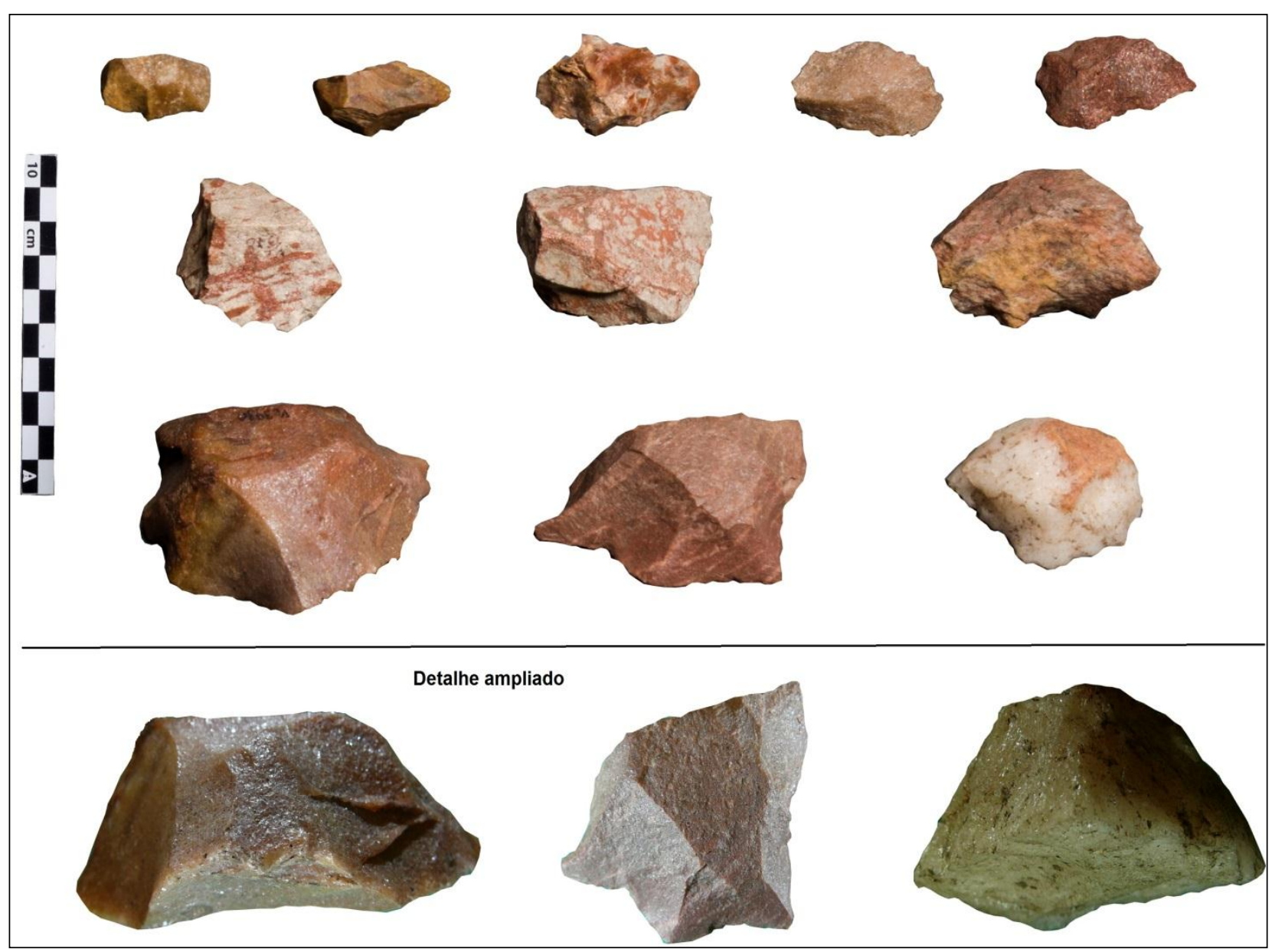

Figura 76 - Artefatos do conjunto 9. Foto - A. Gotardo, 2014.

\subsubsection{Conjunto Artefatual 10}

O conjunto 10 é o que mais se aproxima do que se convencionou denominar artefatos de ocasião, podendo ser descritos como diversos, amorfos e com modificações marginais. Este conjunto é composto basicamente pelo aproveitamento de fragmentos oriundos de cadeias operatórias elaboradas, com retoques assimetricamente distribuídos nos bordos e distribuição dos ângulos de remoção são abruptos, e variando entre $80^{\circ}$ a $100^{\circ}$. As formas atípicas e aleatórias apresentam sequências de retoques que não visam a obtenção da simetria nem tampouco uma nítida diferenciação entre área de apreensão e da parte ativa. Isso faz com que pensemos nestes artefatos como detritos de lascamento pouco valorizados por seus produtores. Esta hipótese pode ser assim entendida, se considerarmos apenas as variáveis de morfologia e extensão dos retoques como expressão da habilidade do artesão, 
desconsiderando a característica peculiar que é projetar em uma forma não concretizada, designs conhecidos, mantendo a relação entre volume e gume de forma definida.

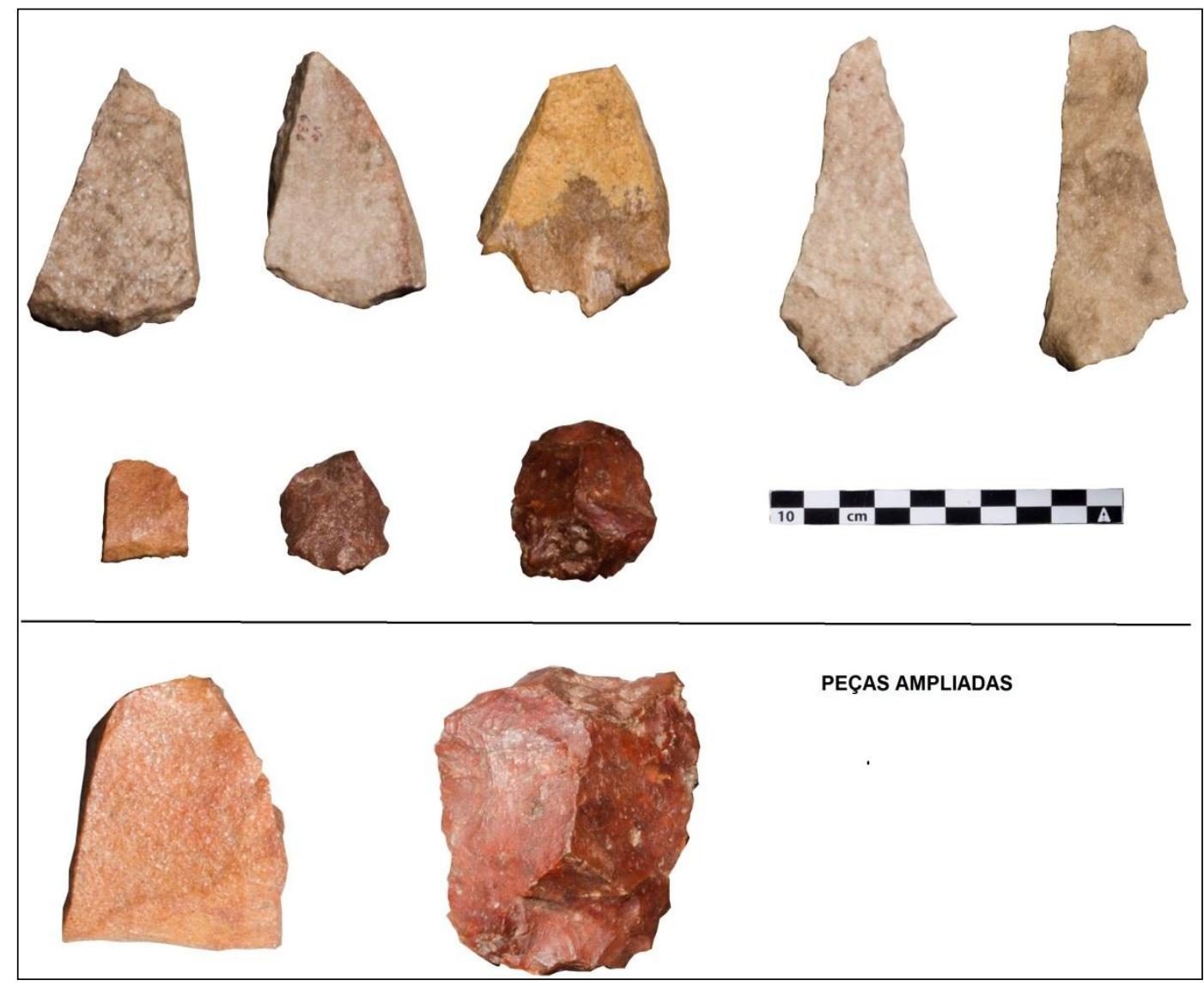

Figura 77 - Artefatos do conjunto 10. Foto - A. Gotardo, 2014.

\subsubsection{Conjunto artefatual 11 - Óxido de Ferro}

Os suportes compostos do conjunto 11 apresentam uma cadeia operatória muito curta, baseada na quebra de matérias-primas constituídas por pequenos seixos, blocos ou plaquetas com volumetria preferencialmente quadráticas ou baseadas no aproveitamento de lascas de óxido de ferro. É frequente encontrar na escavação este tipo de vestígio que com traços de abrasão é denominado "lápis” ou crayon, (PAILLET, 2006, 98).

Segundo os pesquisadores que estudaram as técnicas de expressão da arte rupestre de Abrigos Vermelhos (PAILLET, 2006, VIALOU, 2003, 2006, 2013), tal qual em diversos sítios da Cidade de Pedra, os bordos estreitos destes pequenos seixos e plaquetas são utilizados para criar desenhos lineares, sendo o último tipo de técnica empregada no sítio (VIALOU, 2013, p.32, PAILLET 2006, p.98-100). A aplicação do óxido de ferro em alguns 
traçados gravados ou picoteados indicam certa imbricação das técnicas e uma eventual simultaneidade de execução ou pelo menos de ligações de fases de execução de atividades rupestres que são consideradas de pouca duração (VIALOU, 2006, p.128).

Na utilização do óxido de ferro, nota-se que esta matéria-prima é marcada pelo imediatismo dos procedimentos técnicos e pelo aproveitamento de suportes pouco transformados, sendo que a forma e o tamanho de pequenos seixos, blocos e plaquetas não está direcionada para a produção de cadeias operatórias que reduzam uma massa, mas para o contato entre a matéria-prima e a mão do produtor de arte rupestre que inclui o movimento de esfregar, girar, degastar, muitas vezes sobre o mesmo ponto ou no mesmo sentido das mãos sobre o objeto, como pode ser notado a partir de estrias ou alisamento da superfície, [Figura $78, \mathrm{~d}]$.

A variabilidade dos suportes utilizados representados por blocos, seixos e plaquetas talvez indique que se produza o mesmo resultado a partir de suportes diferentes, ou, que, de outra forma, cada tipo de suporte produza uma resultado específico conforme a utilização do óxido de ferro, na fase de moagem ou na aplicação direta sobre a parede, e, que, neste caso, o nível de redução é propício a atividades em que se exija precisão entre a apreensão da mão e objeto, independente da transformação intensiva e organizada em etapas de redução, [Figura $78, \mathrm{~b}, \mathrm{c}]$. 


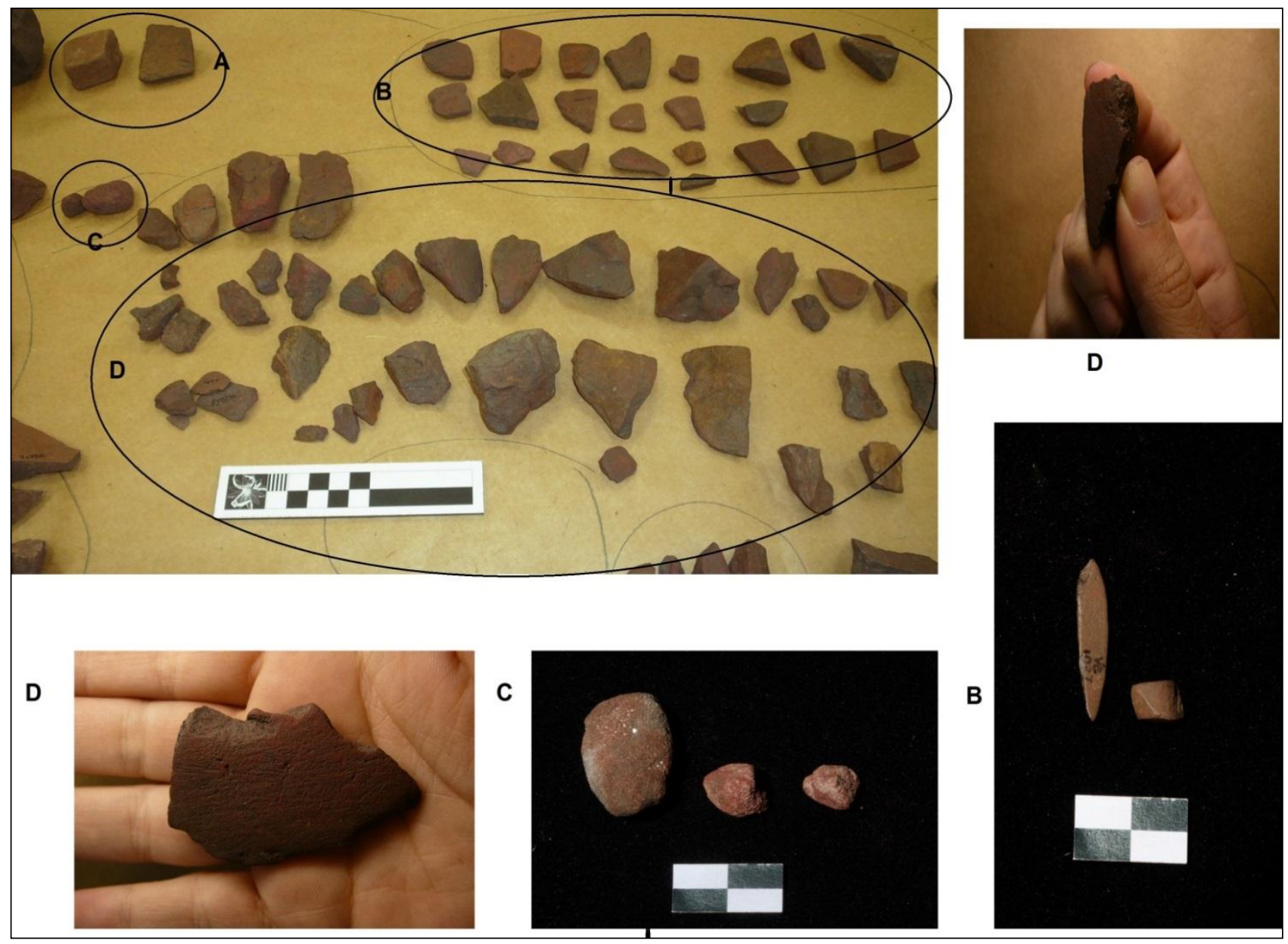

Figura 78 - Plaquetas, seixos, blocos e fragmentos de Óxido de Ferro. Foto: I. Doneux, 2012.
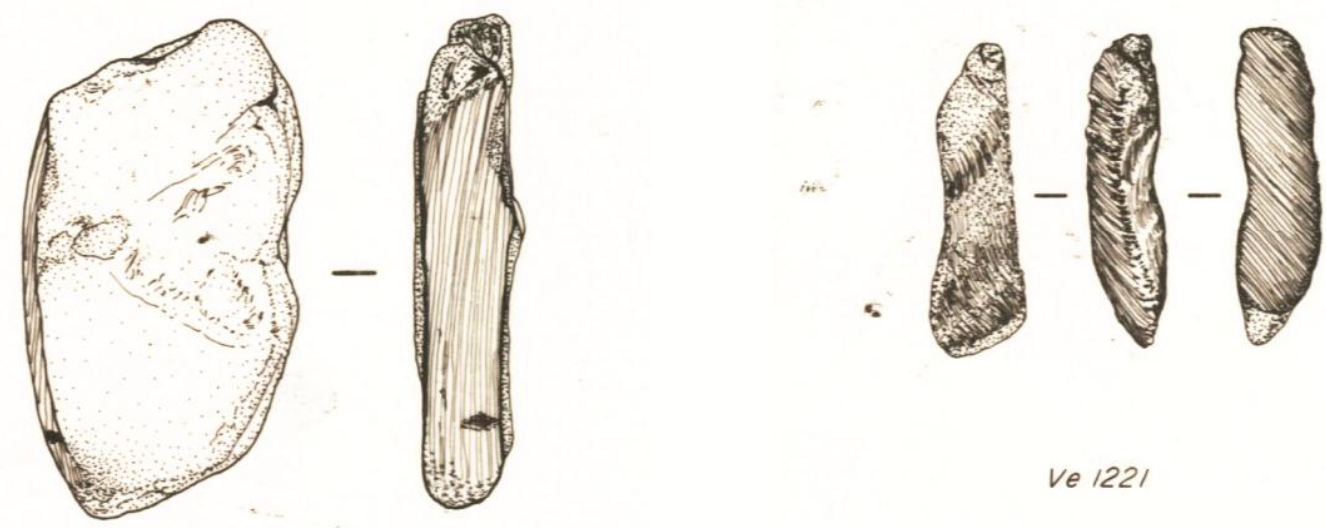

Ve 1221

Figura 79 - Desenho de observação, s/d. 


\subsection{SÍNTESE DO CAPÍTULO}

A análise sugere métodos distintos de redução, cujas séries de operações técnicas apontam para o uso de diversos procedimentos, e, assim, pode-se considerar a tecnologia da coleção lítica de Abrigos Vermelhos, heterogênea. Isto significa dizer que os procedimentos técnicos adotados não se reportam a um mesmo padrão tecnológico para toda a indústria lítica.

Estão presentes três métodos que se relacionam com a qualidade e o tipo de matérias primas. O primeiro foi denominado método A e trata-se de sistema composto pela parcela de sílex e arenito silicificado fino cuja preparação e observação do perfil das lascas, ângulo de remoção e tipo de talão indiciam redução bifacial e produção de artefatos planos convexos. $\mathrm{O}$ segundo método foi denominado $B$, sendo um sistema de redução baseado em indícios de redução de lasca suporte a partir de um núcleo organizado e concerne à parcela de arenito silicificado grosso mais coesa em que estão presentes lascas de etapas preparatórias de núcleos e vestígios de redução laminar. $\mathrm{O}$ terceiro método foi denominado $\mathrm{C}$ abarca matérias primas variáveis e refere-se à confecção e aproveitamento de lascas em fases iniciais de lascamento, de formas retangulares ou quadráticas, [tabela 12].

\begin{tabular}{|c|c|c|c|}
\hline Conjunto & Método & Quantidade & Porcentagem \\
\hline C1 Sílex & $A$ & 450 & $26 \%$ \\
\hline C2 Sílex & $A$ & 233 & $14 \%$ \\
\hline C8 Arenito Sil. Fino & $A$ & 312 & $18 \%$ \\
\hline C9 Arenito Sil. Fino & $A$ & 364 & $21 \%$ \\
\hline C10 Arenito Sil. Fino & $A$ & 192 & $11 \%$ \\
\hline C11 Arenito Sil. Fino & $A$ & 160 & $10 \%$ \\
\hline Total & & 1711 & $100 \%$ \\
\hline C4 Arenito Sil. Grosso & B & 312 & $43 \%$ \\
\hline C5 Arenito Sil. Grosso & B & 309 & $42 \%$ \\
\hline C6 Arenito Sil. Grosso & B & 10 & $1 \%$ \\
\hline C7 Arenito Sil. Grosso & B & 101 & $14 \%$ \\
\hline Total & & 732 & $100 \%$ \\
\hline C1 Arenito Sil. Grosso & $\mathrm{C}$ & 53 & $5 \%$ \\
\hline C2 Arenito Sil. Grosso & $\mathrm{C}$ & 102 & $11 \%$ \\
\hline C3 Arenito Sil. Grosso & C & 47 & $5 \%$ \\
\hline C12 Arenito Sil. Fino & C & 202 & $21 \%$ \\
\hline C1 Rocha Verde & C & 209 & $22 \%$ \\
\hline C1 Óxido de Ferro & $\mathrm{C}$ & 341 & $36 \%$ \\
\hline Total & & 954 & $100 \%$ \\
\hline Total analisado & & 3397 & $100 \%$ \\
\hline
\end{tabular}

Tabela 12 - Conjuntos líticos conforme os métodos A,B,C. 
A síntese da tecnologia contida no interior dos conjuntos litológico, assim como as principais características descritas em cada estudo de caso da produção artefatual serão expostas a seguir, elencando-se os principais elementos técnicos que discriminam os métodos de redução.

A síntese pode ser apresentada da seguinte forma:

Método A -

\begin{tabular}{|c|c|c|c|}
\hline Suporte & Média \% & córtex & Média \% \\
\hline \multirow[t]{2}{*}{ Seixo } & 100 & Sim & 5,1 \\
\hline & & Não & 93,4 \\
\hline Preparo de Talão & Média \% & Percussão & Média \% \\
\hline $\operatorname{sim}$ & 30,6 & Direta Dura & 77 \\
\hline \multirow[t]{2}{*}{ não } & 69,3 & Direta Macia & 4 \\
\hline & & Não Identificada & 20,2 \\
\hline Classe de Lasca & Média \% & Classe de Talão & Média \% \\
\hline Simples & 30,85 & Cortical & 7,18 \\
\hline Inicial & 1,5 & Liso & 57,68 \\
\hline Descorticamento & 7,5 & Diedro & 2,2 \\
\hline Siret & 4 & Facetado & 6,35 \\
\hline Com Dorso & 4,6 & Linear & 11,58 \\
\hline Flanco de Núcleo & 2,45 & Esmigalhado & 1,65 \\
\hline Reavi. De Núcleo & 0,8 & Puntiforme & 3,96 \\
\hline Com Crista & 0,8 & Retocado & 0,65 \\
\hline Preparo de Núcleo & 23,65 & Outros & 5 \\
\hline Acabamento & 17,75 & & \\
\hline Retoque & 14,83 & & \\
\hline Bipolar & 4,15 & & \\
\hline
\end{tabular}

Tabela 13 - Média das classes de análise nominais do método A.

Ocorre o lascamento apenas em seixos, majoritariamente sem cortéx, sugerindo que etapas iniciais de redução foram realizadas em outro local. Embora prevaleça lascas sem preparo de talão, este método possui a média mais alta de preparo de talão e identificação de uso de percussão direta macia. Destaca-se a prevalência de etapas de redução a partir de etapas intermediárias, se encaminhando em direção a etapas de estruturação e ou finalização de artefatos. Embora os talões mantenham-se majoritariamente lisos, por meio da observação do preparo do talão, verifica-se retiradas muito finas que exigem acurácia técnica. 
A particularidade das descrições realizadas no interior dos conjuntos litológicos possui a peculiaridade de descrever detalhes que as médias gerais não alcançam. Neste sentido, vale dizer que neste método ocorre a debitagem de pequenos seixos com uma sequência regular focada em suportes muito pequenos ou etapas específicas de redução. As lascas das fases intermediárias de redução exibem em sua face externa concavidade, como se uma lasca preparada tivesse sido destacada ou retirada por percussão direta dura, com orientações centrípetas na face externa, produzindo aresta guia e remetendo a um tipo de redução de planos convexos. As lascas de acordo com fases de estruturação ou finalização de artefatos possuem esmero de produção e evidências de percussão direta macia a partir de bulbos vagamente definidos e ângulos de percussão maiores que $90^{\circ}$ e estão de acordo com indícios de produção de artefatos bifaciais. Possui correlações técnicas com o conjunto artefatual 6 , de modo que a série de retiradas apresentam sequências de retoques focados na formatação de design específico. Estas retiradas concernem a uma série de retoques diretos, escalonados, profundos e invadentes, localizados continuamente em toda a extensão de apenas um bordo. Os ângulos de remoção estão em torno de $110^{\circ}$.

\section{Método B -}

\begin{tabular}{|c|c|c|c|}
\hline Suporte & Média \% & Córtex & Média \% \\
\hline Bloco & 99,8 & Sim & 3,8 \\
\hline Seixo & 2,3 & Não & 97,1 \\
\hline Preparo de Talão & Média \% & Percussão & Média \%2 \\
\hline Sim & 18,1 & Direta Dura & 87,9 \\
\hline Não & 86,4 & Não Identificado & 10,3 \\
\hline Classe de Lasca & Média \% & Classe de Talão & Média \% \\
\hline Simples & 35 & Cortical & 3,6 \\
\hline Descorticamento & 8 & Liso & 74,1 \\
\hline Siret & 9,6 & Diedro & 3,6 \\
\hline Com Dorso & 0,6 & Facetado & 7,8 \\
\hline Flanco de Núcleo & 2 & Linear & 5,6 \\
\hline Preparo de Núcleo & 25,8 & Esmigalhado & 2,7 \\
\hline Acabamento & 23,3 & Puntiforme & 7,7 \\
\hline & & Outros & 1,1 \\
\hline
\end{tabular}

Tabela 14 - Média das classes de análise nominais do método B.

Este método é quase completamente composto por redução sobre blocos. Prevalece a maior parte de lascas sem preparo específico e menor quantidade de lascas com preparo de 
talão, utilizando percussão direta dura e em menor quantidade percussão não identificada. As etapas de redução remetem a etapas de preparo de núcleo e acabamento que indica reestruturação de artefatos ou façonnage. Os talões são predominantemente lisos e outras classes de talões possuem médias inferiores a 8\%. É composto basicamente por duas técnicas distintas: a primeira produz lascas ligeiramente mais largas que compridas, a segunda é composta por lascas mais compridas que largas, criando aresta guia central por meio de retiradas centrípetas. Na primeira técnica, as etapas de preparação de núcleo remetem a lascas quadráticas com volume poliédrico, enquanto na segunda técnica a preparação de núcleos possui dimensões mais alongadas que largas e criação de aresta guia. Além disso, sua morfologia apresenta volumetria adequada ao aproveitamento de detritos conhecidos como cassons. Possui correlações técnicas com os conjuntos artefatuais 2,3,4,5 e 9.

Ocorre a este método o aproveitamento da porção mesial de lascas, com faces de fratura paralelas, provenientes de massas volumosas. Neste processo, massas grandes e volumosas foram reduzidas em fragmentos menores, tornando-se cúbicas, mantendo a proporção entre o comprimento, largura e altura. Reporta-se a uma sequência de redução intencional, evidenciando a existência de uma cadeia operatória de produção de lascas preparadas, deixando séries de negativos sistematicamente paralelos no dorso. Estas peças indicam que, após, ou concomitante ao espatifamento dos blocos matriciais, procede-se à debitagem de núcleos para as retiradas de lascas grandes e alongadas, as quais podem ser utilizadas como suportes de artefatos unifaciais, sugerindo seção transversa trapezoidal, cuja distribuição dos ângulos está entre $90^{\circ}$ e $100^{\circ}$. 


\begin{tabular}{|c|c|c|c|}
\hline Suporte & Média \% & Córtex & Média \% \\
\hline Bloco & 92,45 & Sim & 28,18 \\
\hline Seixo & 10,1 & Não & 70,56 \\
\hline Não Identificado & 28,5 & & \\
\hline Plaqueta & 42,5 & & \\
\hline Preparo de Talão & Média \% & Percussão & Média \% \\
\hline Sim & 13,14 & Direta Dura & 83,44 \\
\hline \multirow[t]{3}{*}{ Não } & 83,16 & Direta Macia & \\
\hline & & Bipolar & 10 \\
\hline & & Não Identificada & 15,67 \\
\hline Classe de Lasca & Média \% & Classe de Talão & Média \% \\
\hline Simples & 25,6 & Cortical & 11,67 \\
\hline Inicial & 7 & Liso & 74,42 \\
\hline Descorticamento & 22,32 & Linear & 5,6 \\
\hline Siret & 10 & Esmigalhado & 4 \\
\hline Flanco de Núcleo & 1,9 & Facetado & 3,7 \\
\hline Preparo de Núcleo & 28,8 & Punitiforme & 5,4 \\
\hline Acabamento & 5,5 & Outros & 3,1 \\
\hline Retoque & 6,4 & & \\
\hline Bipolar & 10 & & \\
\hline
\end{tabular}

Tabela 15 - Média das classes de na análise nominais do método C.

Neste método blocos são predominantemente aproveitados, embora o aproveitamento de suportes seja mais diversificado. A média de lascas que possuem córtex aumenta, denotando etapas de desbastamentos de matérias-primas. A média de preparo de talão é a mais baixa dentre os métodos descritos e a percussão é predominantemente direta dura. Destaca-se que as etapas de redução focam-se em etapas iniciais avançando até etapas intermediárias de redução. As classes de talões não denotam trabalhos específicos realizados sobre os mesmos. Possui indícios de redução de núcleo em início de debitagem, observandose a retirada de lascas espessas em fase de descorticamento, cuja redução não parece ir além, mas apresenta redução regular em um material muito friável ou não apto ao lascamento e o aproveitamento de fragmentos e de pequenas plaquetas ou seixos que representam uma cadeia operatória curtíssima. Este método de redução possui correlações técnicas com os conjuntos $1,10,11$ e 12 cujos suportes demostram marcas de retiradas, batidas e desgaste, com retoques assimetricamente distribuídos nos bordos e distribuição dos ângulos de remoção abruptos, variando entre $80^{\circ}$ a $100^{\circ}$. As formas atípicas e aleatórias apresentam sequências de retoques que não visam obtenção da simetria nem tampouco uma nítida diferenciação entre área de apreensão e da parte ativa do artefato.

A partir dos resultados de análise é possível afirmar que a indústria lítica de Abrigos Vermelhos não se trata de conjuntos tecnologicamente simples ou formalmente menos 
padronizados, mas que há assinatura tecnológica de produção de artefatos bifaciais e planos convexos e de vestígios de redução laminar nas séries de lascas examinadas, além de assinaturas tecnológicas de produção de artefatos planos convexos na produção artefatual nos métodos A e B. Além disso, há uma parcela do material analisado que comporta $22 \%$ da coleção, cuja assinatura tecnológica se relaciona com a pouca modificação do suporte, com indícios de queda de investimento técnico no referido método de redução C. Aventa-se a hipótese de que a queda de investimento técnico delimitado a partir deste método esteja voltada para a preparação do espaço do sítio, e, portanto, mantém relações com a arte rupestre, como examinado no capítulo a seguir. 


\title{
CAPÍtULO V
}

\section{RETOMANDO AS ESCALAS DE ANÁLISE}

\author{
O palco é a principal área de rotinas
}

(TURNER, 1988, p.74)

\subsection{O SENTIDO DE LUGAR EM DIFERENTES ESCALAS}

Neste capítulo as escalas de análise serão relacionadas, com o objetivo de articular a tecnologia lítica vista em contexto de deposição e à paisagem do sítio Abrigos Vermelhos. Isso se fará por meio da hipótese de que as relações entre os vestígios arqueológicos são elaboradas ao longo do tempo conforme a construção de sentido de lugar.

As informações são extraídas dos resultados de análise que precedem este capítulo, produzindo reflexões sobre o fenômeno de interação entre os vestígios arqueológicos. O desafio é pensar em certos aspectos da organização interna do espaço do sítio e relacioná-los a diferentes escalas de abrangência.

A estruturação do pensamento baseia-se respectivamente no estudo: da zona de captação dos recursos litológicos e do contexto geormorfológico da Cidade de Pedra; das matérias-primas vistas cronologicamente em função dos processos deposicionais no sítio; de discriminações dos processos de manufatura no repertório artefatual lítico, que incluem lascamento e a produção de arte rupestre vista a partir do óxido de ferro ou corantes.

O alcance das escalas de análise difere em amplitude sobre o mesmo tipo de cultura material, o material lítico. Através de diversas resoluções, originou-se a noção de contexto e a noção da influência deste contexto na produção da cultura material e na interação com registros arqueológicos distintos.

Ampliamos o foco de análise da perspectiva artefatual lítica vista isoladamente, para a concepção de que decisões tomadas sobre a manufatura lítica estão conectadas à organização do espaço interno do sítio e aos elementos que compõem este espaço. O fator proeminente é que tentamos delimitar as tarefas desenvolvidas, ajustando as atividades praticadas em macro e microescala.

Nesta perspectiva, não consideramos o sítio como um ponto estático e a paisagem que o circunda como um conjunto reduzido de elementos que mede e mapeia o espaço. Desse modo, a paisagem passa a ter significado cultural. Isto sugere que abordagens que reduzem o 
comportamento humano a um desejo de maximizar ganhos econômicos e minimizar riscos e esforços podem ser questionadas (BRÜCK \& GOODMAN, 1999, p.9).

Optou-se por partir da escala mais abrangente, que inclui a região da Cidade de Pedra até alcançar a uma análise particularizada dos processos de produção da cultura material lítica. Os recursos de captação litológica são importantes fontes de informações sobre a área de circulação de pessoas e recursos, além de modos de interações entre ambas, principalmente através do que podemos denominar caminhos.

Os caminhos pertencem à paisagem (ZEDEÑO \& STOFLE, 2003 p. 59). Neste sentido, referem-se à materialidade encontrada no percurso e prevê a necessidade de análise dos elementos que os compõem, porém não são tratados como um meio para um fim, mas como percursos que organizam os modos pelos quais as pessoas usam e modificam a natureza, influenciam e são influenciados por seus arredores (ZEDENÕ \& STOFLE, 2003, p. $61)$.

A área sob análise abarca as fontes de extração de matéria-prima lítica, estendendo-se desde as vertentes do Planalto dos Alcantilados até às áreas de planície peripantaneiras, ampliando a zona de circulação de recursos e pessoas para além do perímetro das formações geológicas do núcleo central da Cidade de Pedra.

Estas localizações e distâncias oferecem as coordenadas pelas quais o observador tem de passar para atingir os pontos de extração dos materiais líticos, de modo que caminhos e percursos ao longo do contexto geomorfológico devem ter se tornado conhecidos ao longo do tempo até Abrigos Vermelhos. Assim, estes elementos exibem um papel em como podem se estruturar experiências coletivas nos Abrigos Vermelhos.

Do ponto de vista topográfico, este sítio é privilegiado e comunica-se com diferentes locais da Cidade de Pedra, sugerindo que a orientação do percurso imbrica em componentes de memória que atuam na apreensão das características físicas do conjunto de maciços areníticos. Componentes de memória são compreendidos como criações de relações com o espaço através do movimento de pessoas e recursos reforçando laços espaciais e ideias sobre os lugares nos quais se circula (VAN DYKE \& ALCOCK, 2003, p.5).

Nesta escala, a geoestrutura da Cidade de Pedra passa a ser a principal característica a ser examinada, indicando que suas implicações físicas estão para além das potencialidades de extração econômica e aptidão ao lascamento das matérias-primas. Considera-se essencial discutir tais implicações dentro de um panorama de movimentações e interações humanas, que podem ser observadas na paisagem, no sítio e na cultura material. 
Esta prerrogativa é corroborada pelo ponto de vista arqueológico ou mesmo antropológico e ou histórico, haja vista que por esta extensão espacial das áreas do Pantanal com terras secas, ainda hoje, os Bororo a consideram área sagrada, e, assim, perspectivas naturais e culturais convergem, indicando que a paisagem adquire significado para os grupos que ocuparam a região.

Este estudo, porém, está restrito aos dados de análise litológica, e, neste sentido, delimitamos a área e os pontos de coleta de matérias líticos dentro e fora da Cidade de Pedra como configurações contextuais específicas que revelam o percurso, os fatores geomorfológicos e topográficos integrados ao sítio Abrigos Vermelhos.

$\mathrm{O}$ primeiro contexto de ponto de coleta de material litológico refere-se à relação estabelecida com o rio Vermelho, apontada pela existência de seixos de sílex e arenitos de fina granulometria presentes no abrigo e que não são observados nas imediações, mas, potencialmente recolhidos em diferentes trechos e distâncias que procedem de formações geológicas a montante.

O principal aspecto neste caso é que a captação de recursos está direcionada para as áreas de vertentes, envolvendo outro contexto ambiental, a bacia do ribeirão Ponte de Pedra (SILVA, 2013, p.29), [figura1]. Este complexo compreende a área peripantaneira da bacia hidrográfica do rio Vermelho (NARDES, 2005, p.11).

A delimitação deste contexto coloca em questão se este é um caminho que se faz sem que se passe necessariamente pelo núcleo central da Cidade de Pedra, local de instalação da maioria dos sítios ceramistas, denotando uma possível rota diferenciada de acesso ao sítio, porém, sem que haja necessariamente a integração com a área do núcleo central ruiniforme.

O segundo percurso refere-se ao encaminhamento para a zona de extração de matérias primas-líticas dos arenitos de grossas e médias granulometrias, encontrados nos afloramentos residuais do núcleo central da Cidade de Pedra. O fator paisagístico proeminente é que as formações rochosas ruiniformes agregam os patamares escalonados da erosão diferencial da formação geológica Furnas e Ponta Grossa, com delineações diversas das formas erodidas para quem sobre elas caminham.

Aqui o deslocamento na paisagem se faz de um ambiente fechado de savanas e de bosques do cerrado e das arboretas que lhe servem de suporte, para outro ambiente onde estão assentados os sítios ceramistas, em que se privilegia a amplitude da área de planície e o fundo do vale do rio Vermelho, que formam terraços amplos, os mais baixos inundáveis na época das cheias. 
A observação da variedade das descontinuidades físicas dos arenitos silicificados provenientes de afloramentos rochosos do núcleo central da Cidade de Pedra é indispensável, uma vez que mantêm entre si formas naturais, nas quais ocorrem feições estruturais orientadas preferencialmente para NE-SW e NW-SE. Estas feições são caracterizadas pelo extenso lineamento, na qual se pode observar melhor silicificação, em cujos pontos os arenitos de melhor coesão foram extraídos (SILVA, 2013, p.29).

Esta observação é ditada pela caracterização das qualidades de aptidão ao lascamento, permitindo considerar que o uso da memória e da experiência pessoal com o material lítico move interesses de grupos ao se deslocarem dentro do núcleo central da Cidade de Pedra, a fim de extrair os recursos selecionados.

Pensa-se nas características de busca por arenitos silicificados melhores consolidados no percurso, pois quando se caminha sobre uma trilha ao longo da encosta, esse percurso favorece o acesso aos sítios ceramistas e outros abrigos localizados na zona central da Cidade de Pedra, não muito distante dos Abrigos Vermelhos. Percorrer este circuito torna evidente de que este sítio integra-se ao que podemos chamar de área arqueológica da Cidade de Pedra, embora não esteja especificamente dentro dela, e esta região apresente certa compartimentação em função de contatos entre sítios de arredores mais próximos.

Nesta perspectiva, é interessante refletir sobre porque um sítio que não faz parte do conjunto integrado de rochedos erodidos componentes deste núcleo central, possui uma longa cronologia de ocupação precedente à instalação de grupos ceramistas nas várzeas do rio Vermelho e continua a ser visitado ao longo do tempo.

O terceiro contexto de proveniência de material litológico a ser analisado refere-se à zona de contato que está para além do perímetro do núcleo central, concernente à extração de rochas metassedimentares afetadas por metamorfismo regional em contato com arenitos da Formação Furnas, denominadas comumente de rocha verde (SILVA, 2013, p.27).

Esta é a área que conecta a Cidade de Pedra com as baixadas do Pantanal matogrossense, sendo as várzeas ou as baixadas que ladeiam a Cidade de Pedra, as interligações hídricas e o regime das águas que proporcionam as mudanças paisagísticas mais significativas. Assim, estas particularidades naturais indicam que outra configuração ambiental está inclusa no perímetro da Cidade de Pedra, além do núcleo arenítico ruiniforme e das áreas a montante.

O fator proeminente da relação entre as cercanias do Pantanal mato-grossense e Abrigos Vermelhos é o contato de rede ramificada e intermitente de rios e riachos que diminuem a vazão na época de seca e inclui o córrego da Sucuri, localizado a poucos metros 
do sítio. Do ponto de vista da comunicação e acesso os corpos d'água, estes são considerados caminhos que facilitam estratégias e modificações de espaços sociais que permitem mover-se com facilidade e transportar pessoas e recursos (ZEDEÑO \& STOFLE, 2003, p.63).

Já do ponto de vista paisagístico, pode significar uma mudança substancial na forma de apropriação do espaço conforme alterações nos sistemas drenagem dos rios, alterando a relação entre a planície e a vertente, ou a configuração entre cenários muito distintos, cuja relação passa a se estabelecer entre uma área muito planificada e outra com cota altimétrica acentuada, no caso específico, o sítio Abrigos Vermelhos.

A conclusão desta análise é que o sítio faz parte de unidades fisiográficas dispares não estabelecendo contato apenas com o núcleo central da Cidade de Pedra. O mapeamento dos pontos de extração de matérias-primas líticas coloca em evidência que grupos e ambientes diversos participavam das estratégias de coleta, desbastamento e transporte de matériasprimas até ele.

Não obstante, deve-se mencionar que a circulação de recursos e pessoas não se faz retilineamente. Desse modo, outros pontos e sítios podem ter sido anteriormente visitados antes que os recursos litológicos tenham alcançado Abrigos Vermelhos, hipótese reforçada pela caracterização dos suportes líticos.

As condições das matérias-primas revelam que a maioria delas chega ao sítio previamente processada a partir de tipos de reduções distintas, porém, mantendo a característica central das primeiras etapas de desbastamento efetuadas fora do sítio. Isso observa-se nas médias de ausência de córtex dentre os conjuntos estabelecidos, em que o sílex apresenta-se com $84,5 \%$ do material sem reserva cortical, o arenito silicificado $87,5 \%$ e a rocha verde $87,6 \%$, [tabela 16 ]. 


\begin{tabular}{|lr|}
\hline Máteria Prima & Ausência de Córtex $\%$ \\
\hline C1 Silex & 85,8 \\
C2 Silex & 83,9 \\
Média & $\mathbf{8 4 . 8 5}$ \\
\hline C1 Arenito Silicificado & 98,1 \\
C2 Arenito Silicificado & 62,7 \\
C3 Arenito Silicificado & 46,8 \\
C4 Arenito Silicificado & 99 \\
C5 Arenito Silicificado & 99,4 \\
C6 Arenito Silicificado & 100 \\
C7 Arenito Silicificado & 90,1 \\
C8 Arenito Silicificado & 97,1 \\
C9 Arenito Silicificado & 99,2 \\
C10 Arenito Silicificado & 100 \\
C11 Arenito Silicificado & 94,4 \\
C12 Arenito Silicificado & 63,9 \\
Média & $\mathbf{8 7 , 5}$ \\
\hline Rocha Verde & 87,6 \\
\hline Média & $\mathbf{8 7 , 6}$ \\
\hline \hline
\end{tabular}

Tabela 16 - Média da ausência de córtex nas matérias-primas líticas.

O ponto de convergência desta análise é que a partir de três zonas de captação distintas, a mesma intensidade de redução é efetuada a fim de que seja efetivado o transporte de matérias-primas até o sítio. A reduzida carga de matéria-prima transportada aventa a perspectiva de que o sítio pode ser visto não apenas como ponto de passagem e acesso a outras áreas, mas também como ponto de atração de grupos que para lá se encaminham para a realização de curtos eventos que exijam matéria-prima já pouco ou já muito processada.

Os dados de análise da quantidade da reserva cortical ajudam a delimitar a influência do trajeto sobre as estratégias de redução lítica, cuja caminhada envolvia o cerrado bem denso, o que tornava o abrigo oculto, secreto e camuflado. De fato, é preciso saber chegar até lá, pois não é visível a longa distância. Escalando-se o rochedo é possível enxergar, até onde a vista alcança, um mar de copas das árvores do cerrado e, ao fundo, como cercando a área do platô, os paredões verticais que marcam a borda da encosta da serra (Alcantilados), e uma depressão na direção noroeste em que o platô se abre para o vale ao fundo.

Embora não se veja o vale, pode-se divisar, ao longe, as serras do outro lado do rio Vermelho. Em meio à vegetação estão contidos outros afloramentos com arte rupestre, mas, Abrigos Vermelhos é o maior desta área. Isso significa que o abrigo se integra com facilidade 
à região circundante, seja no topo da chapada, acima dos Alcantilados, e descendo ao longo da encosta, acompanha a drenagem, alcançando-se sem esforço excessivo a área rebaixada do vale do rio Vermelho.

Duas características são centrais a esta observação: a primeira, é que Abrigos Vermelhos não é um sítio facilmente detectado na paisagem, mas, uma vez conhecido, integra-se com facilmente às diversas áreas que abrangem a Cidade de Pedra; e a segunda é que, as suas características de discrição e invisibilidade, permite aventar que seja um local atrativo para atividades específicas.

A partir dessas características, o interesse é saber como o deslocamento na paisagem, que movimenta rotas e recursos litológicos de grupos, pode revelar aspectos sobre a interação destes recursos e de seus agentes dentro do sítio. Este estudo tem como ponto de partida uma condição de integração à paisagem, mediada por uma variedade de influências, que dentre elas, observou-se a temporalidade e a espacialidade das matérias-primas líticas vista em contexto de deposição.

Este é o contexto que estrutura e organiza as observações sobre as matérias-primas líticas a respeito do comportamento especificamente voltado ao acúmulo de cultura material sobre os mesmos pontos dentro do abrigo. Esse acúmulo regular denota rotina e constância de deposição, demonstrando que este comportamento nunca foi abandonado e nem diminuiu ao longo do tempo, o que sugere um importante meio de reprodução social. A interface entre a frequência da distribuição das matérias-primas no sítio e a cronologia estabelecida permite construir algumas considerações sobre a importância da cultura material lítica vista sob este direcionamento. 


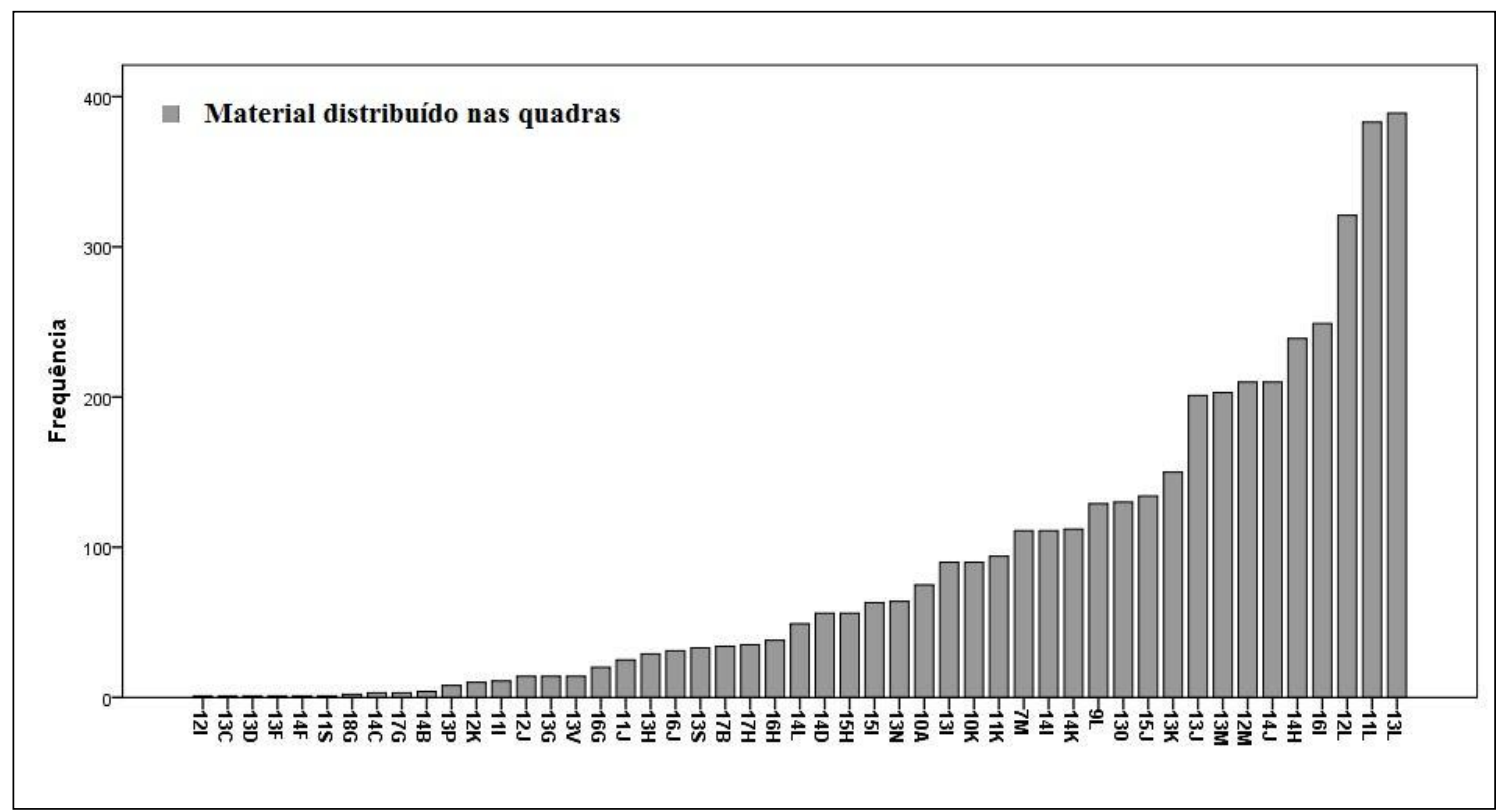

Figura 80 - Frequência do material lítico distribuído nas quadras.

A frequência de distribuição do material nas quadras indica que não há concentração absoluta em alguma área específica de deposição (tabela 172, APÊNDICE 4). No entanto, algumas quadras comportam quantidades mais expressivas de materiais, informação que, somada ao estabelecimento da cronologia do sítio, gerou a classificação de quatro setores ocupados, respectivamente denominados A,B,C,D.

$\mathrm{O}$ setor A comporta as quadras $\mathrm{F}$ e $\mathrm{G}$ e apresenta $0,9 \%$ de material. O setor B abarca as quadras $\mathrm{H}, \mathrm{I}$, J e possui $37,8 \%$ do material. O setor C engloba as quadras $\mathrm{K}, \mathrm{L}, \mathrm{M}$ e comporta $52,7 \%$, enquanto o setor D, agrega as quadras N,O,P,S e totaliza 5,9 \% do material. As quadras A, B, C, D, somam 2,7\% de material e foram descartadas da análise (tabela 172, APÊNDICE 4).

A observação da frequência da distribuição dos vestígios líticos à observação da cronologia do sítio vista em ordem estratigráfica, [figura 72], permite constatar que o setor A e o setor D, são, respectivamente, o contexto de ocupação mais recente e o contexto de ocupação mais antigo, apresentando baixa quantidade de material. Já o setor B e o setor C, localizados no limiar de entrada do abrigo e na área central totalizam 90,5\% do material recuperado na escavação, concentrando quase completamente as atividades que envolvem os materiais líticos. 


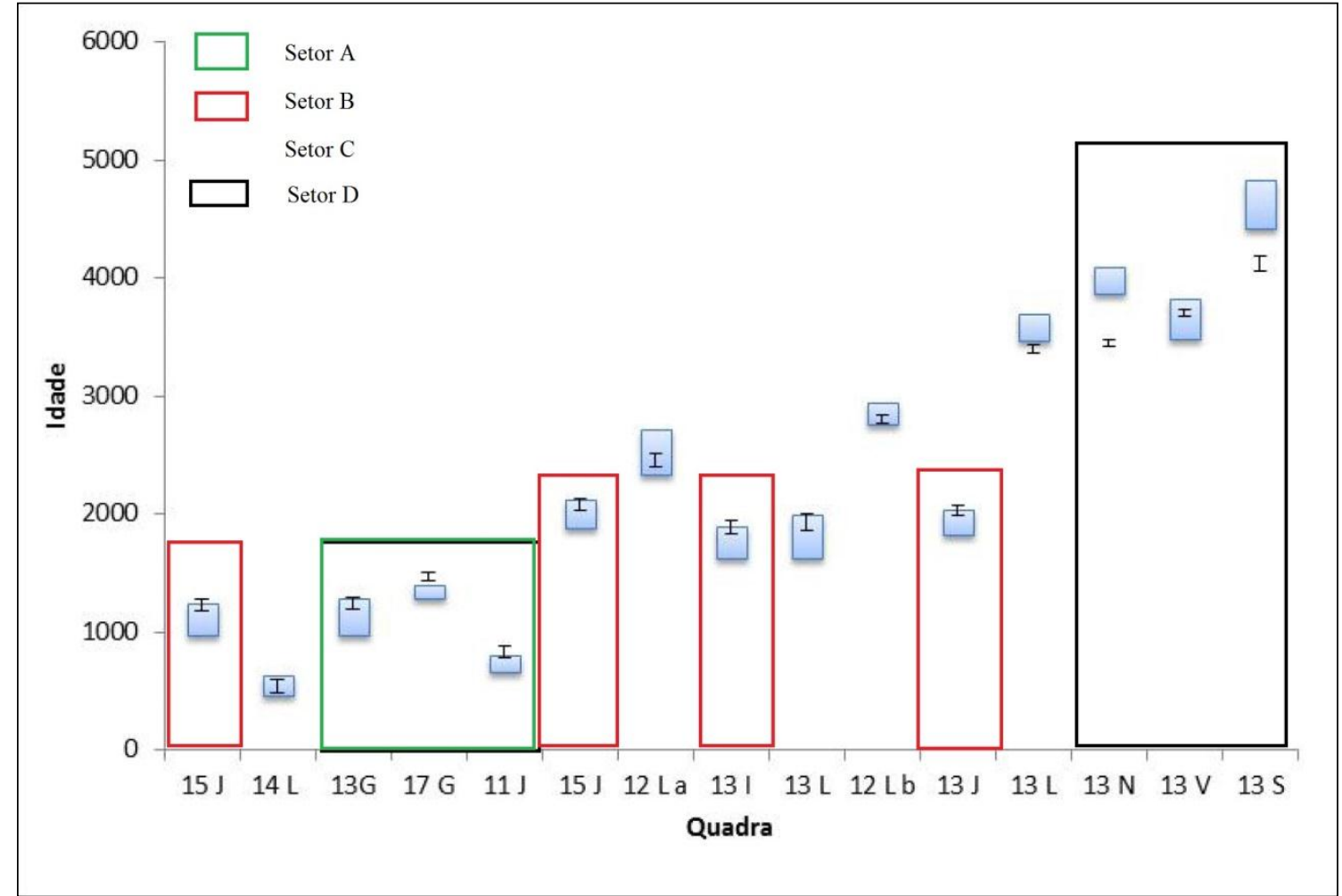

Figura 81 - Distribuição das datações radiométricas em setores.

O resultado das análises sugere que em um espaço externo pouco expressivo quanto ao acúmulo de material, perfazendo um horizonte cronológico de 4.000 AP, a ocupação humana dirige-se progressivamente para o limiar de entrada do abrigo. Isso é demonstrado pelo montante de vestígios depositados no setor $\mathrm{C}$ ou $52,7 \%$, denotando que o fenômeno de acúmulo de material sobre as mesmas estruturas de combustão tem início a partir de contextos datados de 3.400 AP, estende-se ao setor B, com horizonte cronológico estabelecido em torno de $2.000 \mathrm{AP}$, perfazendo 37,8\% dos vestígios que parece se limitar a esta área.

Detecta-se, portanto, em Abrigos Vermelhos a característica de deposição de materiais na área de entrada do abrigo.

Embora esta seja uma característica amplamente discutida dentro da literatura arqueológica. Em grande parte desta literatura considera-se que os processos de deslocamento e erosão são independentes da ação humana (RICK, 1976; VILLA, 1983), e apresentam como causas fatores diversificados de processos de deposição natural. Além disso, ressalta-se que os processos deposicionais variam em intensidade de energia, velocidade, volume de material e forma de deposição (LUCENA, 1992, p.76).

Além dos fatores de estruturação natural do espaço, sua estruturação também é vista como um conjunto de condições sociais e materiais que orientam a continuidade da 
reprodução de estruturas sociais e suas possibilidades de transformações ao longo do tempo.

Parte-se do princípio de que o estudo que visa delimitar esta estruturação social do espaço lida também com características que corroboram ou refutam a hipótese de continuidade da reprodução de estruturas sociais e suas possibilidades de transformações ao longo do tempo. O estudo efetuado nesta direção foi baseado nas remontagens, na verificação da média geral de distribuição vertical das peças conforme a variável z e na distribuição de cada matéria-prima espacialmente e estratigraficamente.

Do ponto de vista espacial, as remontagens revelam que o deslocamento de peças praticamente se limita à área interna do sítio e as quadras geralmente contíguas a elas, como podem ser vistas no APÊNDICE 2, em que se verifica um comportamento ratificador da hipótese de um horizonte estratigráfico de 2.000 AP situado no centro do abrigo.

Nos dados de distribuição das matérias primas líticas analisadas a partir da variável z (profundidade), avalia-se a plotagem geral do material nas quadras, cujo resultado indica que a média de deposição para toda a coleção é de $156 \mathrm{~cm}$ de profundidade, [Figura 82].

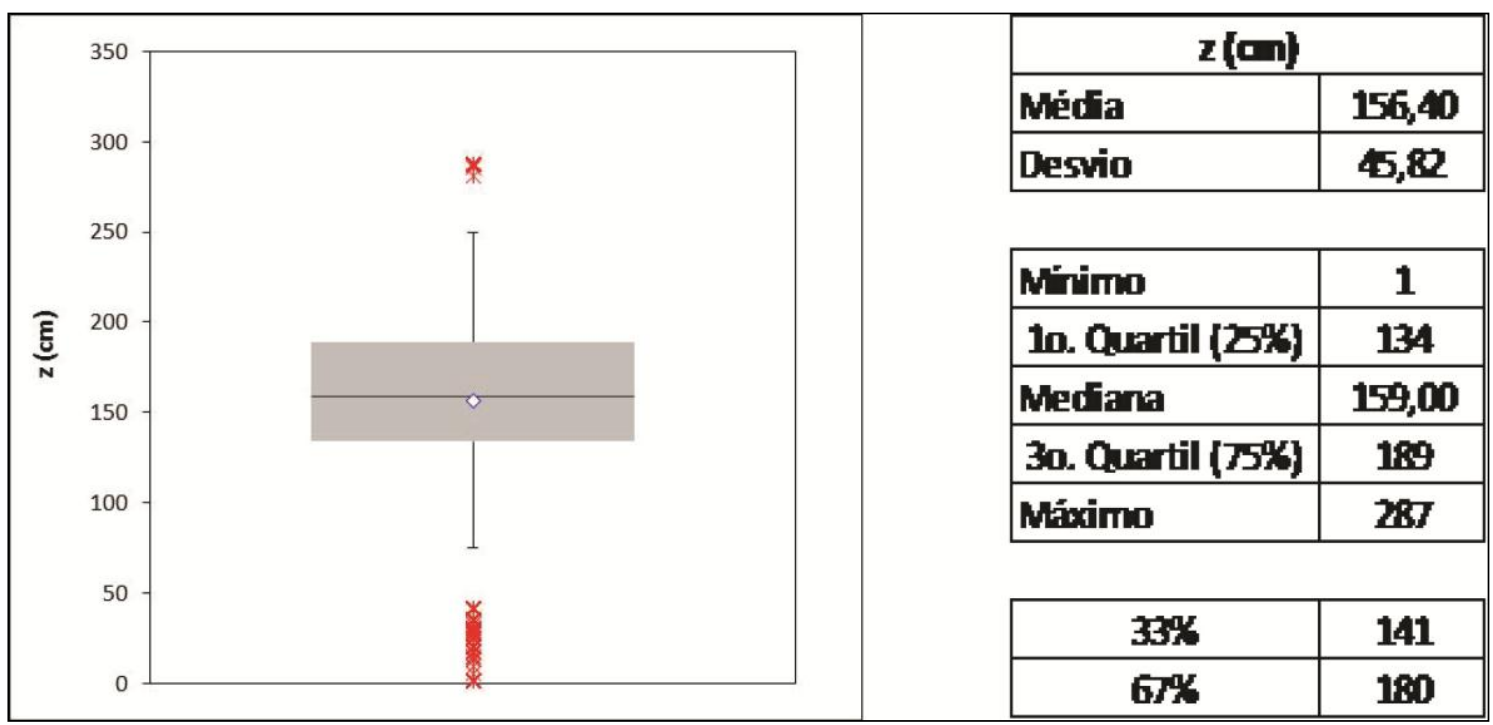

Figura 82 - Média geral da profundidade do material.

Esta é uma informação importante tanto do ponto de vista da delimitação do espaço quanto da delimitação do tempo. Do ponto de vista da deposição estratigráfica, a média geral do sítio é inferior a um horizonte cronológico situado em até $2.000 \mathrm{AP}$, o qual se estende da área mais interna do sítio até atingir a porção central, conforme a análise da distribuição da matéria-prima lítica rocha verde e dos fragmentos cerâmicos. Estes perfazem um horizonte de deposição alocado em até $150 \mathrm{~cm}$, cuja distribuição das médias gerais da profundidade $(\mathrm{z})$ da rocha verde apresentam a média de $111 \mathrm{~cm}$, e a dos fragmentos cerâmicos, $133 \mathrm{~cm}$. 


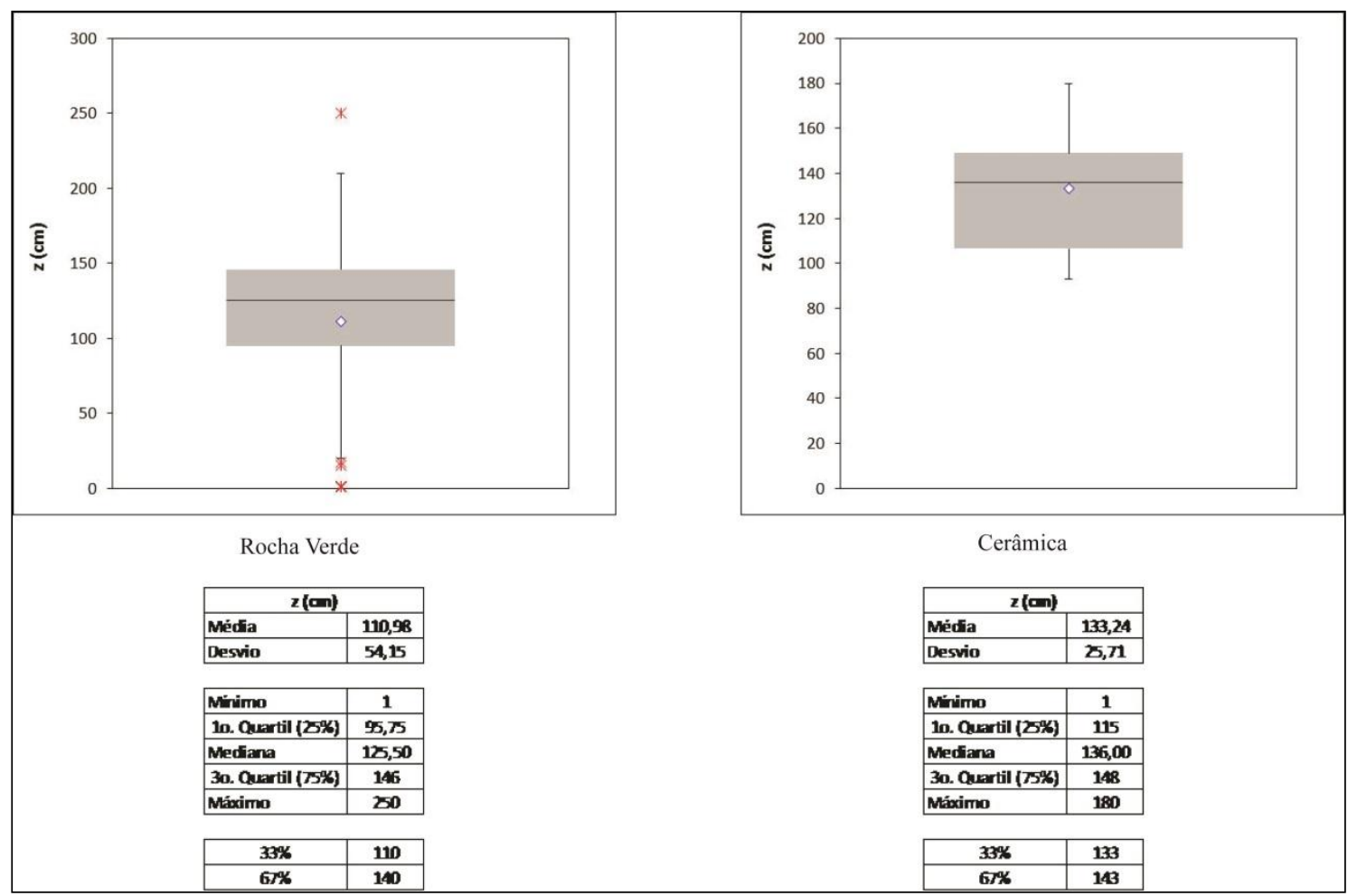

Figura 83 - Média geral da profundidade da rocha verde e da cerâmica.

Portanto, a partir da observação das remontagens, da distribuição da média da profundidade (z) da rocha verde, dos fragmentos cerâmicos e de sua distribuição no espaço do sítio, delimita-se um horizonte cronológico de até 2.000 AP. Vimos que este compreende desde a área mais abrigada do sítio até sua porção central, cuja frequência de materiais reúne $37,8 \%$ de todo material coletado.

Os mesmos testes de remontagens, da verificação da média geral de distribuição vertical das peças conforme a variável (z) e da distribuição de cada matéria-prima espacialmente e estratigraficamente na área do sítio foram realizados na área limiar de entrada do abrigo. Nesta porção, as remontagens demonstram que o deslocamento vertical está presente e apresenta média de $19 \mathrm{~cm}$, além de evidenciarem que as peças estão relacionadas entre níveis superiores e inferiores a $150 \mathrm{~cm}$, como podem ser vistas no APÊNDICE 2.

A média de profundidade da deposição do sílex, arenito silicificado e óxido de ferro são inferiores a $150 \mathrm{~cm}$, denotando um horizonte de deposição abaixo do estabelecido para a área central do abrigo. 
Respectivamente, a média de deposição do sílex é de $162 \mathrm{~cm}$, do arenito silicificado de $159 \mathrm{~cm}$ e do óxido de ferro de $154 \mathrm{~cm}$, cuja distribuição destas matérias-primas não se alocam em níveis estratigráficos específicos, isolados ou delimitados [figura 75].

Não obstante, não parece haver processos de desmoronamento de camadas superiores, instabilidade acentuada do terreno ou mesmo que o processo de declividade detectado na área de entrada do abrigo faça com que as peças se desloquem intensivamente do interior para este setor, mas que convivem, no mesmo espaço desta área processos antrópicos e naturais.

Processos antrópicos testemunhados pela presença de arte rupestre, como registro arqueológico elaborado in situ e pelas matérias-primas líticas sílex e arenito silicificado, situadas preferencialmente nesta área, embora estejam presentes também no interior do abrigo e perpassem horizontes cronológicos estabelecidos em 2.000 AP. 


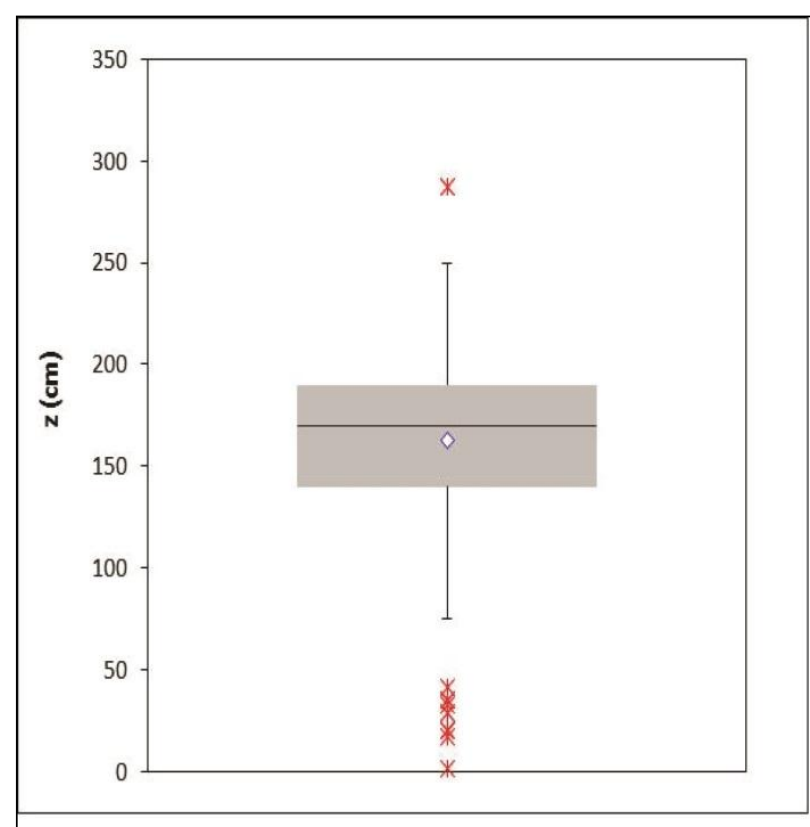

Sílex
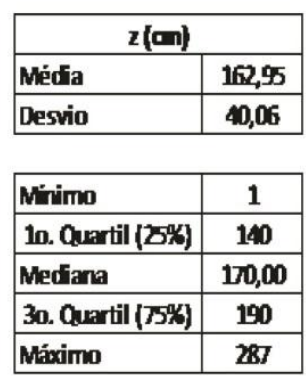

Máximo

\begin{tabular}{|l|l|}
\hline $33 \%$ & 150 \\
\hline $67 \%$ & 187 \\
\hline
\end{tabular}

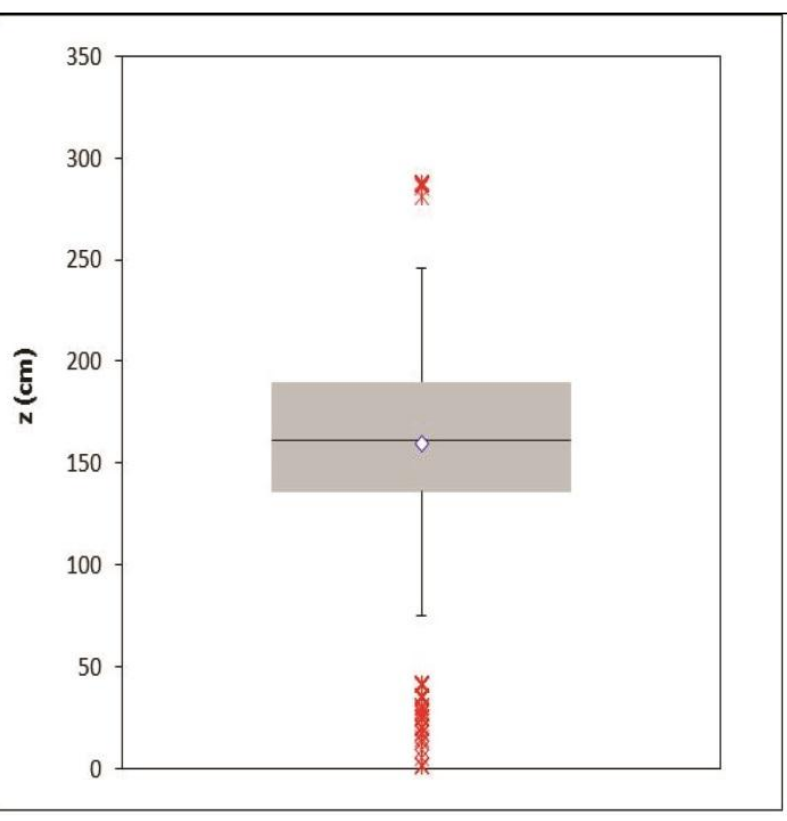

Arenito Silificiado

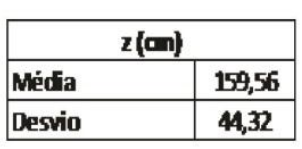

\begin{tabular}{|l|c|}
\hline Mirimo & 1 \\
\hline 10. Quartil (25) & 136,5 \\
\hline Mediana & 161,00 \\
\hline 30. Quartil (75\%) & 190 \\
\hline Máximo & 287 \\
\hline
\end{tabular}

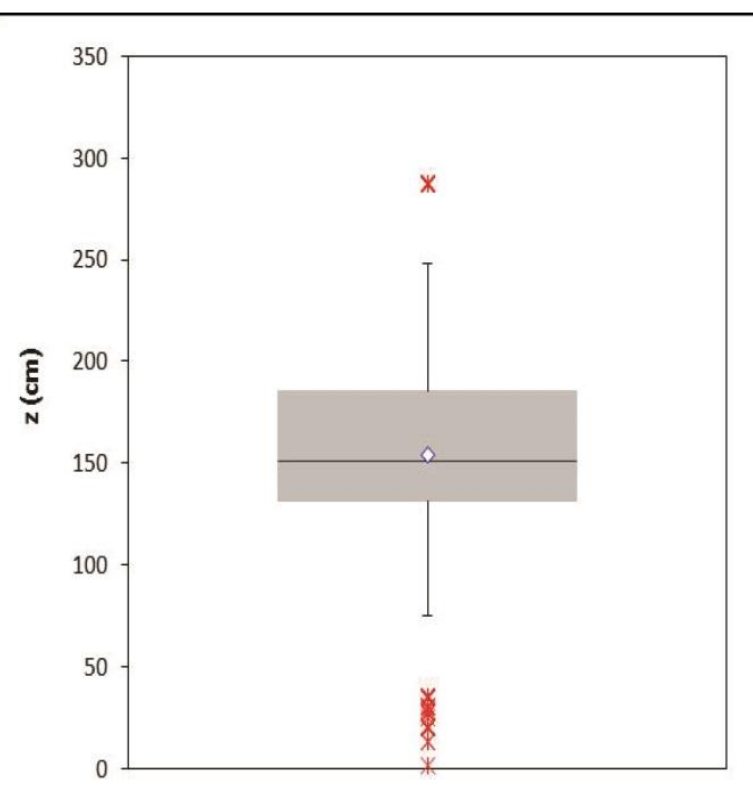

Óxido de Ferro

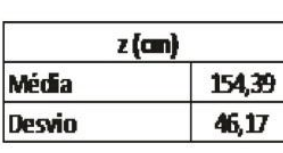

Mrimo \begin{tabular}{|c|c|}
\hline 10. Quartil (25) & 131 \\
\hline
\end{tabular} Mediana 151,00

\begin{tabular}{ll}
\hline 30. Quartil (55) & 185 \\
\hline
\end{tabular}

\begin{tabular}{|l|l|}
\hline 30. Quartil(75\%) & 185 \\
\hline Máximo & 287 \\
\hline
\end{tabular}

\begin{tabular}{|l|l|}
\hline $33 \%$ & 138 \\
\hline
\end{tabular}

Figura 84 - Média Geral da profundidade do sílex, arenito silicificado e óxido de ferro.

\begin{tabular}{|l|l|}
\hline $33 \%$ & 145 \\
\hline $6 \%$ & 182 \\
\hline
\end{tabular}


Portanto, a partir da convergência de análise entre remontagens, da distribuição média da profundidade (z) do sílex, do arenito silicificado e do óxido de ferro, estas matérias-primas se distribuem em horizontes estratigráficos que perfazem um longo período de deposição, entre 500 até 3.400 AP e comportam 52,7\% do material coletado.

Nesta área, os testes efetuados na cultura material lítica e cerâmica conforme a verificação das medidas e dos pesos, verifica-se que a parcela de sílex e arenito silicificado fino é leve e diminuta, podendo deslocar-se com facilidade solo adentro e alcançar o embasamento rochoso, delimitando o fenômeno conhecido como chão de lascas. Este fenômeno é estendido à parcela de arenito de grossa granulometria, mesmo apresentando medidas e pesos mais acentuados.

Contudo, deve-se considerar que uma informação advinda dos estudos efetuados das remontagens é contrária à constatação do fenômeno de chão de lascas. As remontagens apontam que os vestígios arqueológicos se localizam preferencialmente no setor abrigado do sítio e que pouco se movimenta abaixo de $150 \mathrm{~cm}$ de profundidade, APÊNDICE 2.

Deste modo, é possível que pouco tenham se deslocado por uma área tão ampla que inclua o espaço central e o limiar de entrada do abrigo, corroborando a interpretação de que a área de entrada do abrigo ou setor $\mathrm{C}$ preserve aspectos antrópicos específicos de deposição, o que relacionaria o sílex, o arenito silicificado e o óxido de ferro a contextos anteriores a 2.000 AP.

Isto reforça a caracterização dos processos de acúmulo de material como um meio de reprodução social, demonstrando relações e interesses específicos de agentes em relação ao espaço do sítio, no qual se acumulam vestígios ao longo do tempo de maneira rotineira e habitual. Estes vestígios concentram-se em áreas nas quais pessoas conectam práticas sociais organizadas, também denominadas áreas de atividades (DOBRES, 1999, p.128).

Nesta escala de análise, a reprodução social é o eixo que relaciona uma perspectiva em macroescala e uma perspectiva em microescala. A extensa temporalidade de ocupação do sítio e da deposição das matérias-primas apresentam a especificidade de manipulação de cultura material como fruto de estratégias organizadas por indivíduos em longa perspectiva abarcando uma área de extrapola os limites do sítio e incorporando feições fisiográficas distintas. Desse modo, a deposição das matérias-primas dentro do abrigo revela aspectos temporais sobre a movimentação na paisagem de recursos e pessoas.

Sob esta perspectiva, pode-se aventar que o rio Vermelho movimenta o fluxo de acesso às matérias-primas da área a montante. A área central da Cidade de Pedra integra os maciços areníticos em que abrigos rochosos e sítios ceramistas convivem dentro de um leque temporal 
amplo, contextos que parecem relacionar-se com a área de entrada do abrigo em pauta a partir de 3.400 AP. Por sua vez, a área de ocupação central do abrigo, que comporta a maior parcela de rocha verde conecta-se a área peripantaneira e a contextos posteriores a 2.000 AP.

A partir das informações referentes à variabilidade de matérias-primas e de seus processos deposicionais dentro do sítio, é possível inferir que as regiões de vertente e o núcleo central da Cidade de Pedra são áreas primeiro acessadas para coleta de material lítico, e, posteriormente são incorporadas as zonas de extração de material lítico que circundam regiões já pertencentes ao Pantanal mato-grossense.

Tal qual o encadeamento organizado que relaciona a primeira escala da Cidade de Pedra à escala do sítio Abrigos Vermelhos, os processos vistos nas matérias-primas em microescala ou nas atividades praticadas em relação ao processamento do material, fornecem inferências entre as ações técnicas e a construção do conhecimento coletivo sobre o espaço. Isso reflete a necessidade de buscar evidências de ações praticadas dentro deste extenso intervalo temporal, caracterizando a dimensão do estudo da chaîne opératoire, reafirmada através de rotinas de gestos técnicos (DOBRES, 1999, p.126).

A partir desta escala de análise, o foco recai em como a cultura material evidencia comportamentos humanos vinculados aos tipos de matérias-primas, aos tipos de suportes e de discriminações técnicas relacionadas às formas de ocupação do sítio.

No capítulo IV, discriminou-se a existência de três métodos de redução, denominados respectivamente:

- Método A - Indício de produção de pequenos artefatos planos convexos e redução bifacial, que perfaz 50\% do material lítico;

- Método B - Etapas de preparação de núcleo e indícios de produção de lasca suporte, perfazendo $22 \%$ do material lítico;

- Método C - Pouca modificação dos suportes, representados pelo aproveitamento de fragmentos, que perfaz $28 \%$ do material lítico.

É a partir da descrição destes métodos que serão relacionadas informações provenientes desta escala de análise à escala de análise do sítio. Esta relação visa produzir distinções entre os quatro setores detectados em função da cronologia e do acúmulo de cultura material, como esforço de gerar uma síntese de contextos que podem ser tratados como áreas de atividades. 


\subsubsection{Setor A}

O setor A apresenta um quadro de datações mais recentes e concernentes às estruturas de combustão $13 \mathrm{G}, 17 \mathrm{G}$ e $11 \mathrm{~J}$, situadas nesta área, mais plana e abrigada do sítio, [figura 76]. Estas estruturas de combustão são altas e morfologicamente diferentes daquelas localizadas na área central e na área de entrada do abrigo. Apresenta uma superfície limpa entre as fogueiras, sugerindo que os vestígios tenham sido alocados para outras áreas, além de apresentar marcas de fuligem na parede localizada ao lado da estrutura de combustão da quadra 17G. Tais características apontam que esta estrutura tenha sido bastante ativa e que atingisse altura suficiente para alcançar e sobrepor-se às pinturas executadas.

Do ponto de vista da análise espacial, este contexto foi pouco explorado devido a presença de poucos vestígios arqueológicos. A principal caracterização, além da baixa incidência de material, é a ocupação de espaços muito recônditos e apartados de atividades que envolvem ativamente o processamento de matérias-primas líticas.

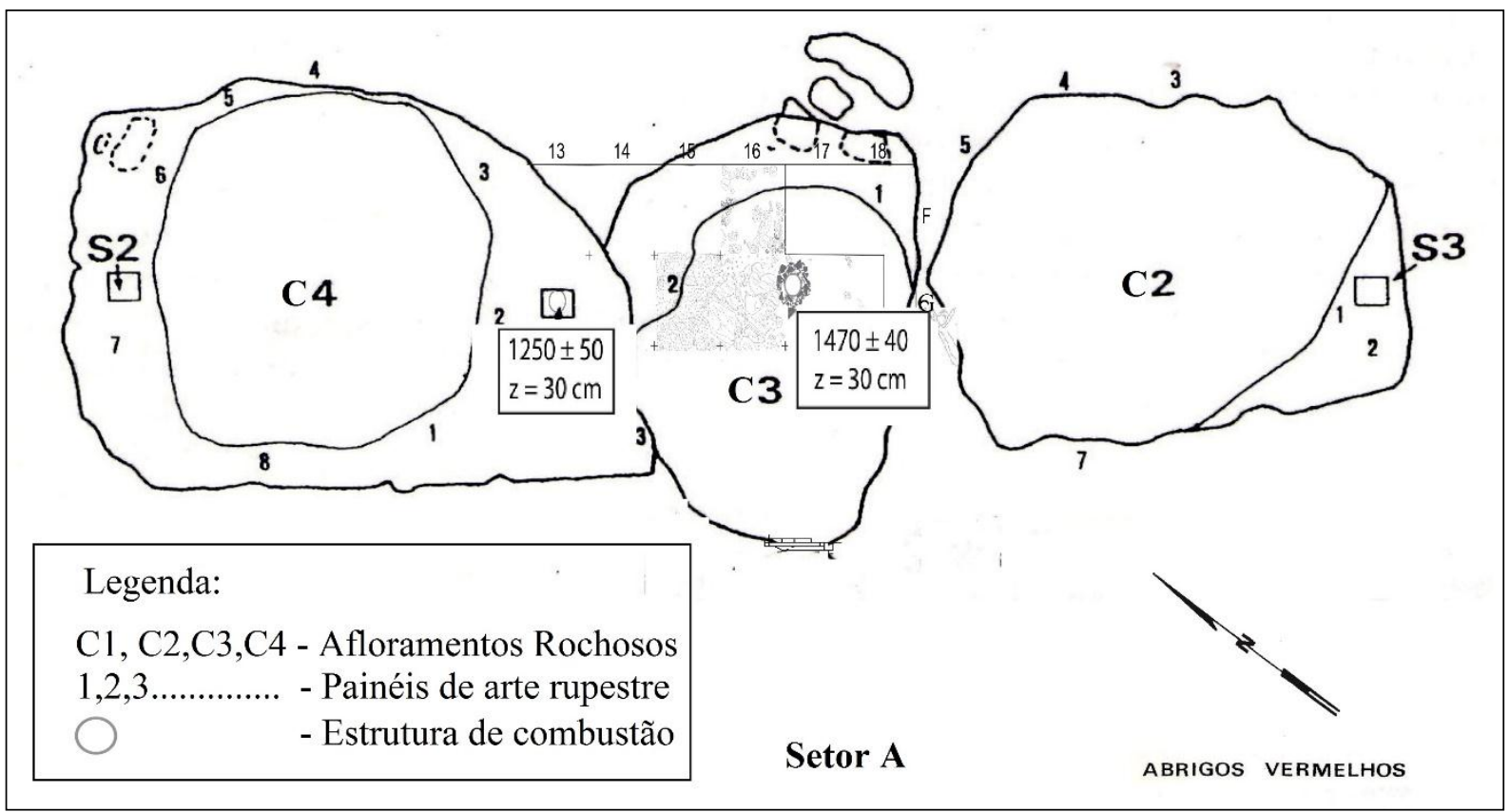

Figura 85- Setor A - Croqui. 


\subsubsection{Setor B}

A área central do abrigo, denominado setor B, [Figura 87], configura-se como um espaço em que estão alocadas estruturas de combustão em camada arenosa de fina textura e datações radiométricas estabelecidas em até 2.000 AP. A estrutura do embasamento rochoso é mais rasa e comporta, além destas estruturas de combustão, todas as matérias-primas líticas e quase exclusivamente a rocha verde.

É também a área onde painéis de arte rupestre estão bastante estruturados às atividades de solo de ocupação, sendo este local a base da escavação realizada, envolvida pelo Painel I do afloramento rochoso $\mathrm{C} 4$. Este painel apresenta uma pátina importante e forte coloração vermelha, de modo que a coloração e as técnicas de expressão o relacionam ao Painel 1 do afloramento rochoso CII, [Figura 86] (PAILLET, 2006, p.104).

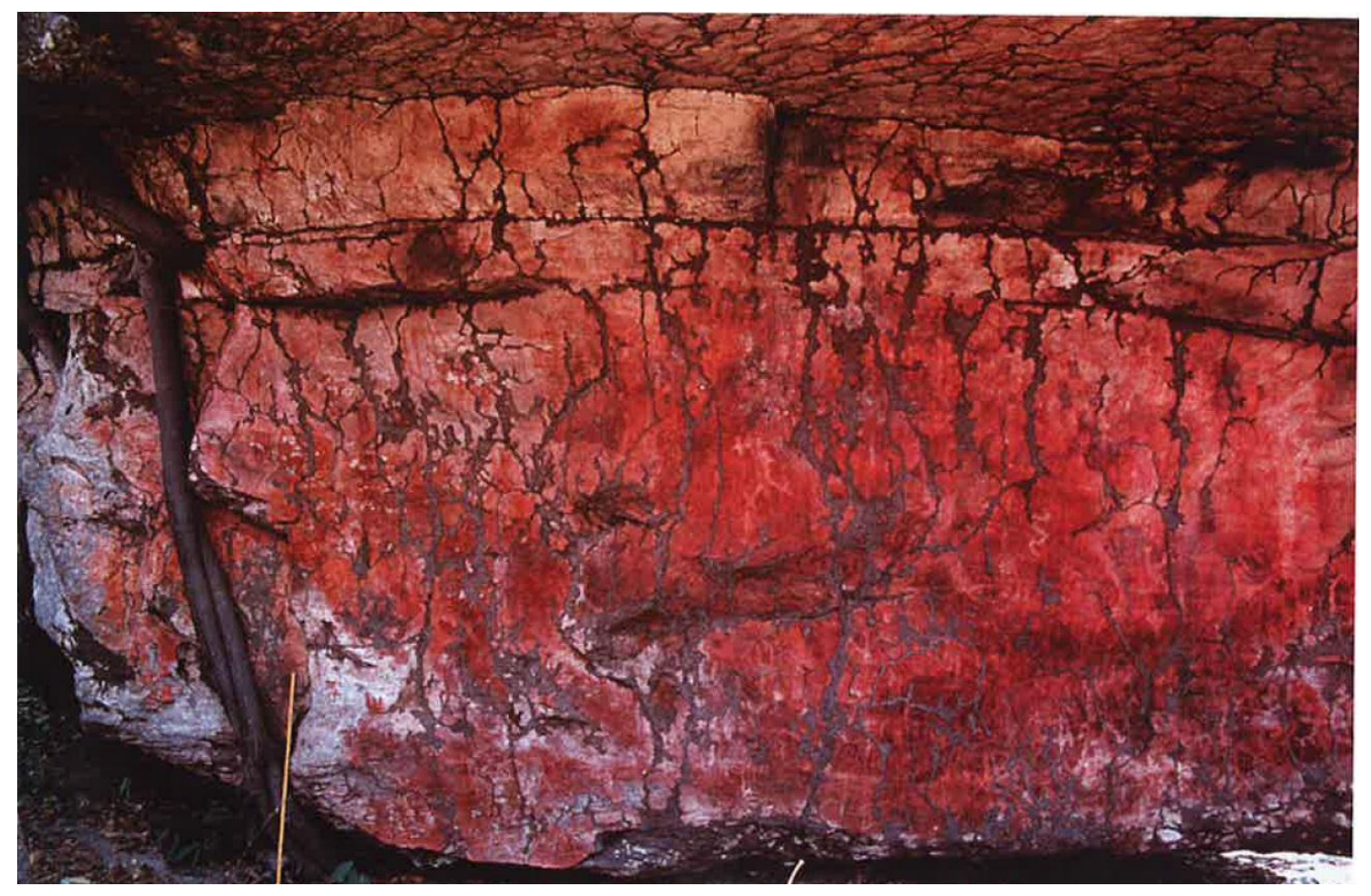

Figura 86 - Painel 1, CII. Fonte: (PAILLET, 2006, p.99).

O lugar é, assim, recoberto de desenhos e pinturas, protegido e escuro no interior, mas aberto para o sul. Este aspecto fenomenológico, embora seja um importante fator a ser considerado, é acessado do ponto de vista da matéria-prima lítica e seu nível de força e 
mobilização social, ou seja, nos esforços empreendidos para que atividades se realizassem no interior do abrigo.

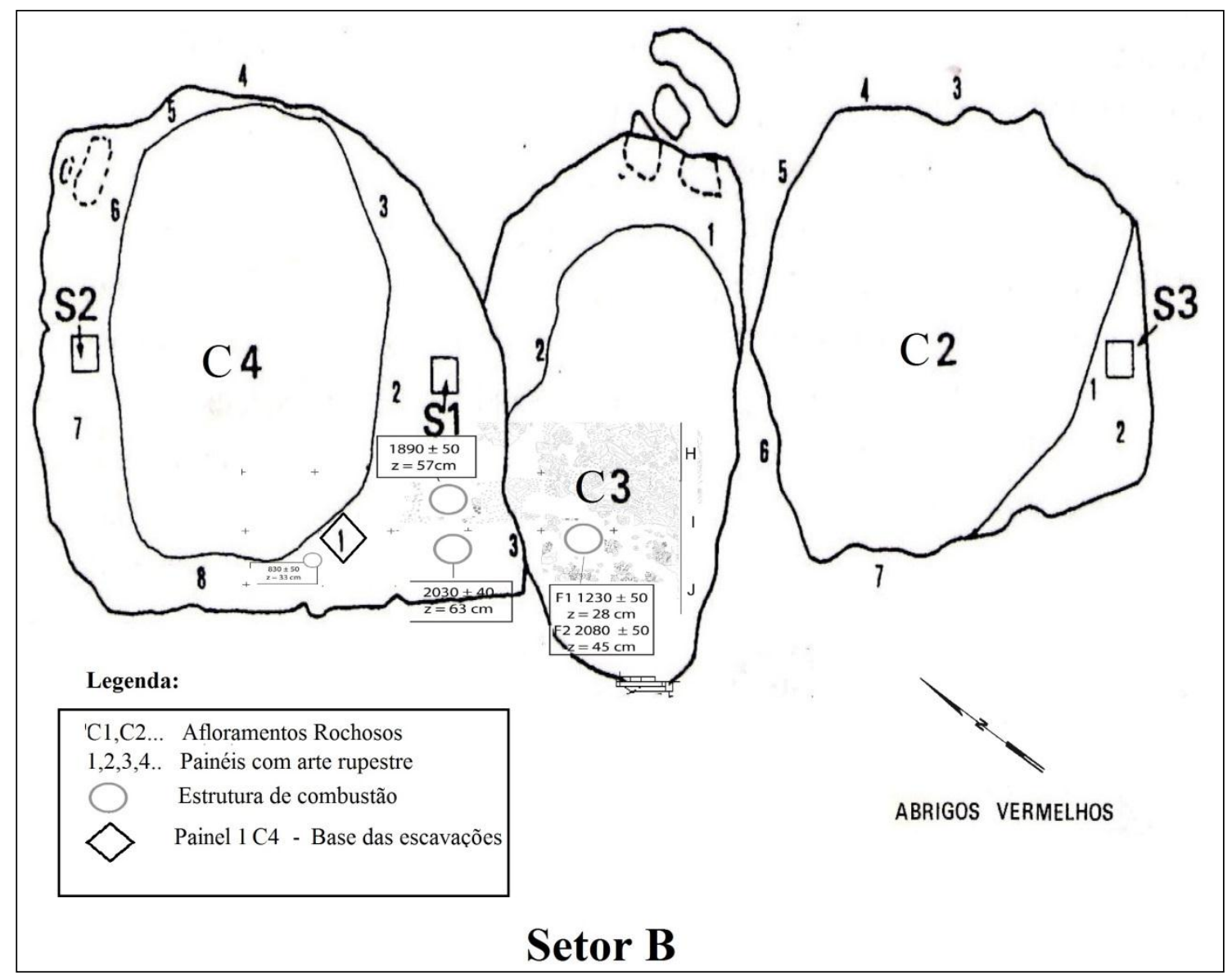

Figura 87 - Setor B - Croqui.

Uma vez descritos os pontos essenciais do setor B para esta análise, a pergunta é como estes padrões de lascamento conectam-se à área do abrigo em horizontes estratigráficos distintos? Dada a circunscrição da rocha verde ao setor B e sua maior compatibilidade com o método $\mathrm{C}$ de redução, além da menor incidência de outros materiais líticos nesta área, melhor distinguiremos aspectos deste método, explorando seu potencial de interação com a área central do abrigo.

Como exposto no capítulo IV, o método de redução C possui indícios de redução de núcleos em início de debitagem, observando-se a retirada de lascas espessas em materiais com características litológicas variáveis, ora muito friável ou não apta ao lascamento, ora com características bastante aptas, tal o caso da rocha verde, além do aproveitamento de 
fragmentos e de pequenas plaquetas ou seixos de óxido de ferro que representam uma cadeia operatória curtíssima.

Neste método os suportes utilizados demostram marcas de retiradas, batidas e desgaste nos bordos das classes de vestígios que não visam obtenção da simetria nem tampouco de uma redução organizada até que se alcancem fases avançadas de debitagem, mas apresentam a peculiaridade de selecionar volumes poliédricos, em qualquer tipo de matéria-prima lítica e produzir artefatos sem uma nítida diferenciação entre área de apreensão e ativa.

Deste modo, aventa-se a hipótese que detritos de cadeias operatórias mais longas sejam transportados da área de entrada do abrigo e aproveitados na finalidade de preparar esteticamente o espaço central. Conforme a caracterização deste espaço central o fator proeminente é que o baixo investimento técnico se relacione ao acompanhamento do efeito do mover-se das ações cotidianas das transformações das matérias-primas líticas, de seus aspectos corriqueiros e habituais, para a possível finalidade de transformar o espaço em outra categoria, como, por exemplo, uma categoria de interação simbólica de alta performance.

Todavia, não há uma real alteração física do espaço, de modo que se encontra no registro arqueológico são apenas os vestígios das atividades realizadas em material lítico com menor intensidade de transformação e métodos de redução menos controlados.

Em contraponto, o único registro que se associa indubitavelmente a uma performance simbólica continua sendo a arte rupestre. Entrementes, este pode ser o aspecto central de interação entre solos de ocupação e a produção de arte rupestre, de modo que no setor B as atividades simbólicas se sobreponham às atividades cotidianas. Os vestígios líticos não apresentam transformações que denotem filiações técnicas ou que o repertório artefatual lítico não é ativamente transformado para ser vetor de identidades ou expressar relações simbólicas, mas que seja acessório à produção de arte rupestre.

\subsubsection{Setor C}

Apesar dos aspectos de movimentações verticais estarem presentes na entrada do abrigo, a distribuição espacial apontar para uma área de processamento de materiais principalmente no que se refere à parcela de arenito silicificado, sílex e óxido de ferro. Os padrões técnicos descritos fornecem indicativos de que para cada tipo de suporte recolhido e proveniente de áreas de captação distintas, também havia procedimentos técnicos distintos. 
As paredes do abrigo são intensamente pintadas e repintadas, gravadas, entre outras ações. São estruturalmente compostas por paredes laterais dos rochedos, quase todas cobertas por uma curta laje saliente formada por uma camada mais dura, menos erodida, da estratigrafia de camadas sub-horizontais de arenitos metamórficos que formam o afloramento.

Do ponto de vista do espaço, delimita-se uma área localizada na zona no limiar de entrada do abrigo, deslocando a ocupação humana para um espaço semiaberto e com interação entre registros materiais em solo de ocupação e possibilidade de visualização de signos visuais nas paredes. Esta confluência de fatores permite criar a relação entre dois sistemas de objetos (LEMONNIER, 1992, p.79).

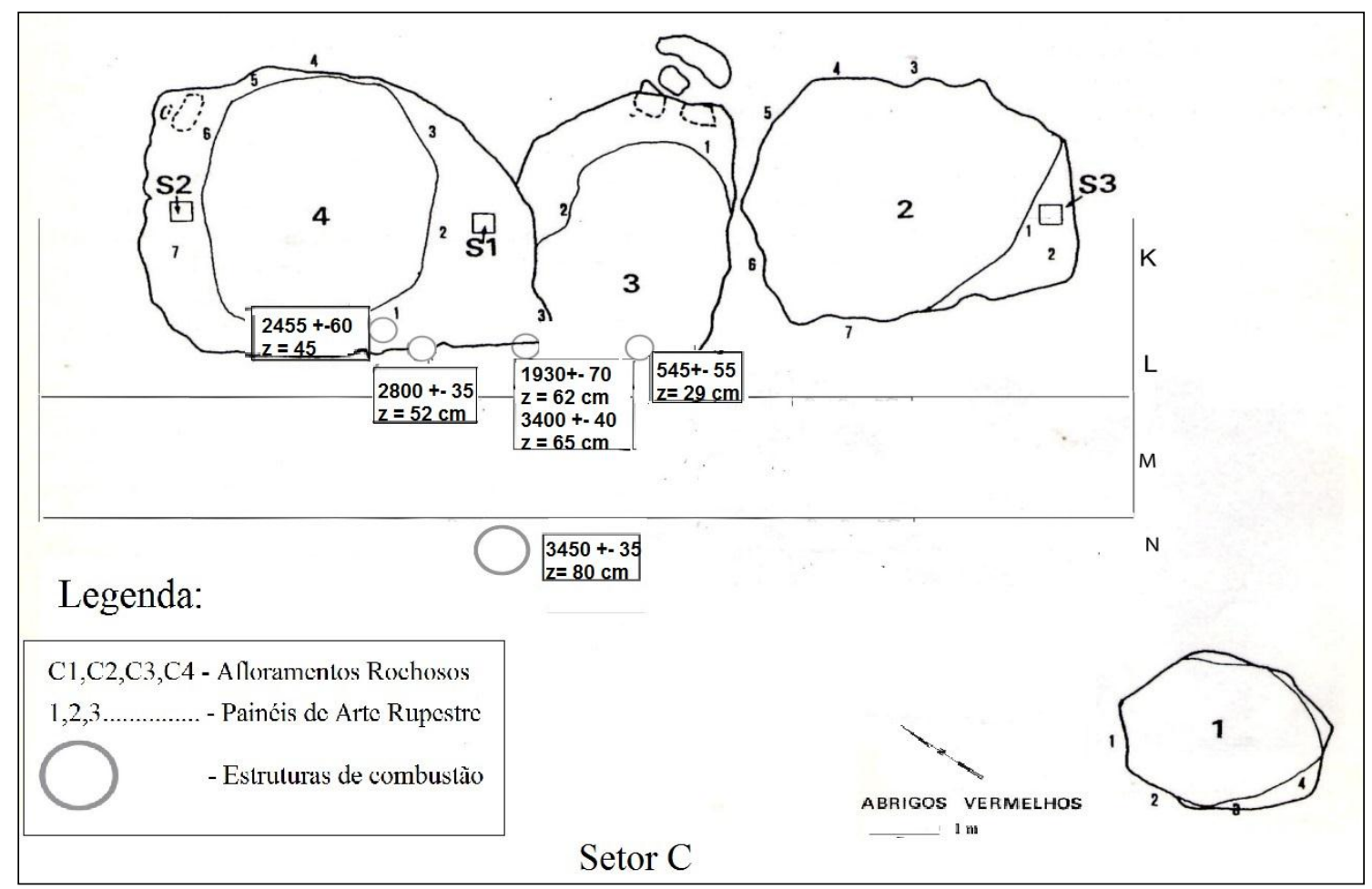

Figura 88 - Setor C - Croqui.

As sequências organizadas de produção fornecem indicações de atividades cotidianas de etapas de confecção, reparo de artefatos ou de descarte de detritos. Nesta área, destaca-se principalmente a redução do método de lascamento A e B, além da presença específica do óxido de ferro.

Conforme visto no capítulo IV no método de redução A ocorre a debitagem somente em pequenos seixos de sílex e arenito silicificado fino com uma sequência regular focada em suportes muito pequenos ou etapas específicas de redução, remetendo a um tipo de redução de 
planos convexos e indícios de reparos de artefatos bifaciais. Além deste método, o método B apresenta indicativos de redução quase completa de blocos compostos pelos afloramentos rochosos do núcleo da Cidade de Pedra.

Reporta-se a uma sequência de redução intencional, evidenciando a produção de lascas preparadas, deixando séries de negativos sistematicamente paralelos no dorso. A sequência de lascamento produz morfologia quadrática e volumetria que produz detritos cúbicos. Neste processo, massas grandes e volumosas foram reduzidas em fragmentos menores, mantendo a proporção entre o comprimento, largura e altura. Tanto o método A, quanto o método B, não perpassam toda a estratigrafia, não sendo definidos em níveis estratigráficos isolados, conforme a análise da distribuição em estratigrafia.

$\mathrm{Na}$ utilização do óxido de ferro, nota-se que esta matéria-prima é marcada pelo imediatismo dos procedimentos técnicos e pelo aproveitamento de suportes pouco transformados, sendo que a forma e o tamanho de pequenos seixos, blocos e plaquetas não está direcionada para a produção de cadeias operatórias que reduzam uma massa, mas para o contato entre a matéria-prima e a mão do produtor de arte rupestre, cuja atividade de pintura, parece ininterrupta conforme a análise da distribuição do óxido de ferro em estratigrafia.

Para entender as atividades aparentemente um tanto quanto específicas que tiveram lugar é essencial articular os eventos parietais aos eventos deixados no solo, pois, do ponto de vista da ocupação, estes vestígios parecem fazer parte de um mesmo conjunto de atividades, ou atividades encadeadas, como numa cadeia operatória.

A proposta da elaboração de uma cadeia operatória que produza conexões entre solos de ocupação e paredes ornadas está para além do escopo deste trabalho, de modo que será apresentada a seguir apenas alguns indicativos explorados a partir da avaliação técnica das matérias-primas e da distribuição destas no espaço do sítio.

O óxido de ferro, torna-se, neste caso, o elemento de ligação de uma proposta de não aparte entre materiais depositados em solos de habitação e dos paredões rochosos. Rochas duras são altamente processadas no limiar de entrada do abrigo e direcionam-se para o território cotidiano, corriqueiro de caça e movimentação na paisagem, enquanto que a partir de um elemento quase in natura, o óxido de ferro, criam-se processos simbólicos sofisticados que se direcionam para o espaço do sítio.

As discriminações dos métodos de redução $\mathrm{A}, \mathrm{B}$ e $\mathrm{C}$ foram fundamentais para a observação da interligação entre processamentos de rochas duras e a transformação dos corantes, que não apresenta nenhum procedimento diferente daquele adotado para a parcela de material do método de redução $\mathrm{C}$. 
Assim, este material destinado à pigmentação das paredes, mantém um repertório tecnológico compatível com a parcela de material pouco transformado, incluindo parte do arenito de grossa e média granulometria e a maior parcela de rocha verde. Diante disso, cabe a pergunta se os produtores de arte seriam os produtores deste padrão tecnológico lítico menos formalizado em arenito silicificado que aproveita-se de detritos para fabricação de artefatos?

\subsubsection{Setor D}

A área externa do abrigo envolve uma espécie de círculo de afloramentos menores ao sul, configurando uma área central plana e naturalmente delimitada, ainda que aberta por todos os lados por entre estes afloramentos. Desta área central foram coletadas duas datações que abrange o horizonte cronológico mais antigo do sítio situado em torno de 4.000 AP. Neste local não se encontram evidências de acúmulo significativo de cultura material e nem mudança no perfil técnico do material lítico, sugerindo que a cultura material pode ter se deslocado do espaço limiar de entrada do abrigo.

Porém, há uma série de estruturas de combustão diferentes daquelas que se encontram incorporadas ao interior do abrigo, sendo estas estruturas diminutas e distribuídas por uma ampla área aberta dos quatro afloramentos rochosos. Esta configuração favorece a hipótese de que esta seja uma área de interação pública, ou múltiplos espaços interligados com continuidade a partir de uma estrutura dominante, o afloramento rochoso $\mathrm{C} 4-\mathrm{C} 3$ do abrigo. Não obstante, este contexto foi explorado apenas em linhas gerais devido à metodologia de pesquisa direcionada para a elucidação do espaço abrigado do sítio. 


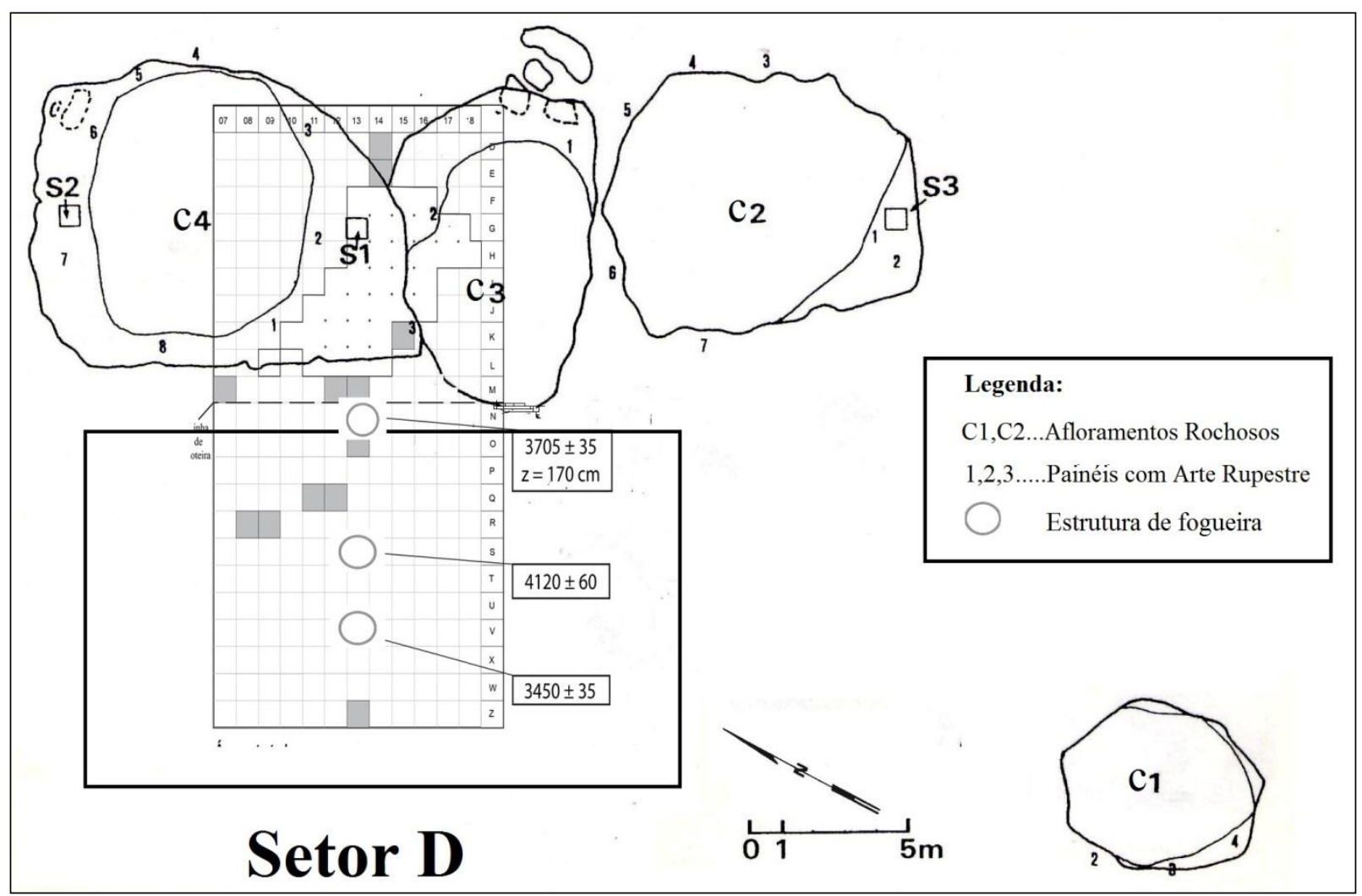

Figura 89 - Setor 4 - Croqui.

\subsection{CONSIDERAÇÕES FINAIS}

Retomamos nas considerações finais as questões propostas na introdução ou a ideia de que os vestígios líticos e parietais encontram-se associados ao contexto de atividades que demandam a articulação de ambos os procedimentos em três escalas de análise. A síntese dos resultados de análise concerne a:

- O sítio faz parte de unidades fisiográficas distintas, não estabelecendo contato apenas com o núcleo central da Cidade de Pedra;

- O mapeamento dos pontos de extração de matérias-primas líticas coloca em evidência que grupos e ambientes distintos participavam das estratégias de coleta, desbastamento e transporte destas até ele;

- A reduzida carga de matéria-prima aventa a perspectiva de que outros locais são previamente visitados; 
- A variabilidade de matérias-primas e de seus processos deposicionais aponta que as regiões a montante da Cidade de Pedra e o núcleo central são áreas de onde primeiro se extrai o material levado até Abrigos Vermelhos, enquanto as áreas que circundam o Pantanal mato-grossense são incorporadas a posteriori.

- A cultura material depositada sobre os mesmos pontos dentro do abrigo denota o aspecto de rotina e constância de deposição, demonstrando que este comportamento nunca foi abandonado ou diminuiu ao longo do tempo;

- A cronologia e a distribuição dos vestígios arqueológicos sugerem que, de um espaço externo pouco expressivo quanto ao acúmulo de material, o qual perfaz um horizonte cronológico em 4.000 AP, a ocupação humana dirige-se progressivamente para o limiar de entrada do abrigo. Esse processo denota contextos datados de 3.400 AP, estendendo-se para a área interna do abrigo, com horizonte cronológico em torno de 2.000 AP.

- No limiar de entrada do abrigo, em horizontes cronológicos datados de 3.400 AP há indício de produção de pequenos artefatos planos convexos e reparo bifacial, e etapas de preparação de núcleo e indícios de produção de lasca suporte;

- No limiar de entrada do abrigo e se estendendo até a porção mais abrigada, há a pouca modificação dos suportes representados pelo aproveitamento de fragmentos. Utiliza-se o óxido de ferro como material para pigmentação das paredes e este mantém procedimentos técnicos compatíveis com a parcela de material pouco transformado, que inclui parte do arenito de grossa e média granulometria e a maior parcela de rocha verde.

Estes resultados contemplam a pergunta elencada na introdução deste trabalho e de forma mais especifica coloca a questão se a tecnologia lítica mais refinada e antiga torna-se menos refinada com o tempo; ou trata-se de um padrão tecnológico homogêneo com variações relacionadas ao uso do sítio e sua localização na paisagem.

Estes padrões tecnológicos parecem sofrer variações conforme o uso do sítio e sua localização na paisagem. Embora não foi possível isolar padrões estratigráficos, a argumentação colocada a partir dos dados de análise corrobora a hipótese de que a ocupação deste sítio se relacione a escalas diversificadas. O lugar é visitado e temporalmente integra pontos distintos da Cidade de Pedra em termos de captação de recursos litológicos, enquanto o espaço de ocupação do sítio parece ir sendo gradativamente construído em torno das áreas 
de atividades que desenvolvem e modificam a relação entre o espaço e tipos de atividades empreendidas.

Em uma área externa, que envolve uma espécie de círculo de afloramentos menores ao sul, configurando uma área central plana, a maior parte das atividades começa a ser realizadas em um espaço semiaberto com a possibilidade de visualização de signos visuais nas paredes, a partir de contextos datados de 3.400 AP. Em contextos datados a partir de 2.000 AP, consolida-se a ocupação de espaço, envolvido por repetitivas construções e paredões areníticos modificados para tornarem-se um produto cultural. Este setor não parece se relacionar simplesmente ao processamento de materiais líticos. Por fim, o espaço mais recôndito do sítio com datações que perfaz um horizonte de deposição de $1.200 \mathrm{AP}$, apresenta uma superfície limpa entre as fogueiras, sugerindo que os vestígios desta área tenham sido alocados para outros locais, destacando-se a preferência pelo aspecto recôndito.

Portanto, o sentido de ocupação de lugar modifica-se com o tempo e a cultura material apresenta padrões técnicos com níveis diferenciados. Não foi possível isolar os métodos de redução identificados ou as matérias primas líticas em estratigrafia, com exceção da rocha verde. Todavia, os métodos de redução A e B são compatíveis com um padrão tecnológico amplamente presente no Planalto Central brasileiro consonante a produção de artefatos planos convexos e resquícios de redução bifacial confeccionados em sílex e arenito silicificado fino, além da produção regular de núcleos em arenito silicificado de média a grossa silicificação.

O método $\mathrm{C}$ reporta-se especificamente ao que poderia ser classicamente denominado expediência lítica. Perante a pouca transformação dos materiais líticos, argumenta-se que a pouca transformação da forma original do suporte não se trata de um aproveitamento imediato marcado pelas condições do ambiente, pela má qualidade da matéria-prima ou pelo decréscimo de habilidades provocadas pela queda de mobilidade, mas trata-se de modificações dos aspectos materiais em função de modificações simbólicas do lugar.

É plausível que a produção tecnológica lítica se torne neste caso, secundária (ou suporte), em relação a uma atividade tecnológica paralela e detentora de valores simbólicos expressivos. Dada a natureza do registro arqueológico no período, esta atividade para qual o abrigo é preparado e abarca relações simbólicas, produzindo um repertório tecnológico especializado para atividades de altas performances é a arte rupestre. 


\section{REFERÊNCIAS BIBLIOGRÁFICAS}

AB’SABER, Aziz Nacib. O Pantanal mato-grossense e a teoria dos refúgios e redutos. In: MODENESI-GAUTERRI, May Christine (org.) [et al.] ; A Obra de Aziz Nacib Ab’Saber. São Paulo: Beca BALL Edições, 2010.

. Paisagens de exceção: o litoral e o Pantanal mato-grossense: patrimônios básicos. Cotia, SP: Ateliê Editorial, 2006.

.Os Domínios de Natureza no Brasil: potencialidades paisagísticas. 2. ed. São

Paulo: Ateliê Editorial, 2003.

ADÁMOLI, Jorge. Bases para uma política comum de conservação das terras úmidas do Pantanal e do Chaco. III SIMPÓSIO SOBRE RECURSOS NATURAIS E SÓCIO ECÔNOMICOS DO PANTANAL. OS DESAFIOS DO NOVO MILÊNIO. Corumbá, Mato Grosso do Sul, 2000. Anais. Corumbá: Embrapa Pantanal, 2001, CD ROOM.2001 b.

ANDREFSKY JUNIOR, William. Lithics: macroscopic approaches to analysis. Cambridge: Cambridge University Press, 2002.

. Raw material availability and the organization of technology. American Antiquity, v. 59 , n. 1,1994 . p. 21-34. [sem local]

Disponível:

http://www.uio.no/studier/emner/hf/iakh/ARK2120/v09/Andrefsky\%201994\%20Raw \%20Material\%20Availability.pdf. Acesso em:20/01/2014

ARAUJO, Astolfo Gomes Mello; PUGLIESE Jr, Francisco. The use of non-flint raw materials by Paleoindians in Eastern South America: a Brazilian perspective. In: Farina Sternke; Lotte Eigeland; Laurent-Jacques Costa (org). Non-Flint Raw Material Use in Prehistory - Old prejudices and new directions. Oxford: Oxbow Books, 2009, v.1939, p.169-175.

; FEATHERS, James. K; ARROYO-KALIM, Manuel; TIKUZA, Michelle, M. Lapa das Boleiras rockshelter stratigraphy and formations at a paleoamerican site in Central Brazil. Journal of Archaeological Science. v.35, p.3186-3202, 2008.

. Peças que descem, peças que sobem e o fim de Pompéia; algumas observações sobre a natureza flexível do registro arqueológico. Revista do Museu de Arqueologia e Etnologia, São Paulo,v. 5. p. 35-45, 1995. 
As propriedades físicas dos arenitos silicificados e suas implicações na aptidão ao lascamento. Revista do Museu de Arqueologia e Etnologia, São Paulo, v. 2. p. 63$74,1992$.

. As rochas silicosas como matéria prima para o homem pré histórico: variedades, definições e conceitos. Revista do Museu de Arqueologia e Etnologia, São Paulo, v.1. p.105-111, 1991.

AUBRY, Thierry. Geologia. Pedra In: VIALOU, Águeda Vilhena (org). Pré história do Mato Grosso. Cidade de Pedra. São Paulo: EDUSP. v.2 p. 21-25, 2006.

AYRES, Fábio Martins. Previsão de cheias via satélite para o planejamento Ambiental do Pantanal: Subsídios para as atividades humanas no complexo. $2004.93 \mathrm{f}$. Dissertação (Mestrado Acadêmico), Universidade Católica Dom Bosco, Campo Grande, MS, 2006.

Disponível em: http://www.cpap.embrapa.br/teses/online/DST17.pdf. Acesso em: 25 de outubro de 2013.

AZEVEDO, Andréia Aguiar.; MONTEIRO, Jorge Luiz Gomes. Análise dos Impactos Ambientais da Atividade Agropecuária no Cerrado e suas inter-relações com os recursos hídricos na Região do Pantanal. In:JACCOUD, D’Alembert de Barros...[et al.]: A avaliação de sustentabilidade do crescimento do cultivo da soja para a exportação no Brasil. Brasília: WWF, 2003.

Disponível: assets.panda.org/dowloads/sustainabilibyassesmentpt_fs60.pdf. Acesso em: 24 de maio de 2013.

BACHELET, Caroline. Apport de l'anthracologie à la conaissance des relations homesmilieux à partir de l’Holocene moyen dans des sites préhistoriques de La Cidade de Pedra (Mato Grosso, Brésil). 2011. 311 f. Tese (Doutorado em Arqueologia) Muséum National d’Historie Naturelle (Paris) et 1'Université de São Paulo (Brésil), Paris, 2011.

BAILEY, Geoff; GALANIDOU, Nena. Caves palimpsests and dwelling spaces: examples from the upper palaeolithic of southeast europe. World Archaeology, v. 41, n.2, pp.215-246, junho/2009.

BALFET, Hélène. Observer l'action technique: des chaînes opératoires, pour quoi faire? Paris: Centre National de la Reserche Scientifique, 1991. 
BARRETO, Cristiana Nunes Galvão de Barros. Meios Místicos de reprodução social: arte e estilo na cerâmica funerária da Amazônia antiga. 2008. 230 f. Tese (Doutorado em Arqueologia). Universidade de São Paulo, São Paulo, 2008. 230 p.

. A construção social do espaço: De volta às aldeias circulares do Brasil central. Habitus, Goiânia, v.9, n.1, jan/jun 2011, p.61-79.

BECK Robert J. Spatial meaning, and the properties of the environment. In: Environmental perception and behavior. Lowenthal, David (ed.). Chicago, The University of Chicago: Department of Geography, Research Paper n. 109, 1967.

BERLEANT, Arnold. The Aesthetic of Environment. Philadelfia,Temple: University Press, 1992.

BINFORD, Lewis Roberts. Pursuit of the Past: Decoding the Archaeological Record. New York: Thames and Hudson, 1983.

. The Archaeology of Place. Journal of Anthropological Archaeology. v.1, 1982. p.5-31

. Organization and formation processes: Looking at curated technologies. Journal of Anthropological Research. v. 35, n.3, p. 255-273, 1979.

Disponível em: http://www.jstor.org/stable/3629902. Acesso em: 20 de outubro de 2012.

. Forty-Seven Trips: A case study in the character of some formation processes of the archaeological record. Ottawa: Musée Nationaux du Canada, Mercury Series, 1976.

. Interssemblage variability: The mousterian and the functional Argument. In:

RENFREW, Colin (ed.). The explanation of Culture Change: Models in prehistory, Proceedings of a meeting of the research seminar in Archaeology and related subjects held at the University of Sheffield. London: Duckworth, 1973. p. 227-254.

. An archaeological perspective. New York: Seminar Press, 1972.

BOËDA, Eric. Levallois: uma construção volumétrica, vários métodos, uma técnica. Canindé - Revista do Museu de Arqueologia de Xingó, Sergipe, n.7, junho, 2006.

BREZILLON. Michel. La dénomination des objets de pierre taillée - Matériaux pour un vocabulaire des préhistoriens de langue française. $\mathrm{IV}^{\circ}$ supplément à Gallia Prehistoire. Editions du CNRS, reimp.,Paris, 425 p, 1977.

BROCHADO, José Proença. An Ecological Model of the Spread of Poterry and Agriculture into Eastern South America. 1984. 573 f. Tesis (Doctor of Philosophy 
et Anthropology). University of Illinois at Urbana- Champaign. The Gratuated College. Philosophy and Anthropology, Illinois, 1984.

BRÜCK, Joanna; GOODMAN, Melissa. Making places in the prehistoric world: themes in settlement archaeology. London: UCL Press, 1999.

BUENO, Lucas de Melo Reis. Variabilidade tecnológica nos sítios líticos da região de Lajeado, Médio rio Tocantins. Revista do Museu de Arqueologia e Etnologia, Universidade de São Paulo. Suplemento n.4, 2007.

CASEY, Edward S. How to get from space to place in a fairly short stretch of time. In: Senses of Place. FELD, Steven \& BASSO, Keith H. (eds.). Santa Fe, NM: School of American Research Press, 1996.

CARSTEN, Janet; HUGH-JONES, Stephen. Introduction. In: CARSTEN, Janet; HUGHJONES, Stephen (eds). About de House Lévi-Strauss and beyond. Carsten, J; Hugh Jones (eds). Cambridge, Cambridge University Press, 1995.

CHIPPINDALE, Christopher. Contested Images: Diversity in Southern African Rock Research. The South African Archaeological Bulletin, v. 51, n.163, jun,1996. p. 42-45. Disponível em: http://www.jstor.org/stable/38888936. Data de acesso: 25 de outubro de 2013.

CLARKE, David L. Spatial Analysis. London; New York; San Franscisco: Academic Press, 1977.

COTTERELL, Brian; KAMMINGA, Johan. The Formation of Flakes. In: ODELL, George H. (org). Archaeological Lithic Analysis: Readings from American Antiquity and Latin American Antiquity. Society for American Archaeology. Washington, D.C.: SAA, Press, 2009. p.37-70.

CRABTREE, Don E. An introduction to flintworking. Pocatello, Idaho. Idaho State University Museum. Occasional Papers of the Idaho Museum Natural History, n.28, 1982.

CUNHA, Manuela Carneiro. Manuela Carneiro da Cunha. Antropóloga Militante. Pesquisa Fapesp. Dezembro de 2009. Disponível em: www.revistafapesp.fapesp.br/wpcontent/uploads/2009/12/010-015-166.pdf. Data de acesso: 14 de fevereiro de 2013.

DeBLASIS, Paulo Antonio Dantas. Abrigos Vermelhos: Habitat. In: VIALOU, Águeda Vilhena (org). Pré história do Mato Grosso. Cidade de Pedra. São Paulo: EDUSP, São Paulo, 2006. v.2. 
- A ocupação colonial do Vale do Ribeira de Iguape, SP. Os sítios líticos do médio curso. 1988. 178 f. Dissertação (Mestrado em Arqueologia). Universidade de São Paulo, São Paulo, 1988.

. Projeto Pré-História e Paleoambiente no Mato Grosso: Estado Atual das Pesquisas.

Revista do Museu de Arqueologia e Etnologia, São Paulo, n.3, 1993. P.221-222.

DILlEHAY, Tom D. The Late Pleistocene Cultures of South America. Evolutionary Anthropology; Issues, News and Reviews. Volume 7, p. 191-224. 1999-2000.

Disponível em http://www.latinamericanstudies.org/ancient/pleistocene-cultures.pdf. Data de acesso: 24 de novembro de 2012.

DOBRES, Marcia-Anne.; ROBB, J. E. Doing Agency: Introductory Remarks on Methodology. Journal of Archaeological Method and Theory, New York: Kluwer Academic: Plenum Press, v.12, n.3, p.159- 166, 2005.

Disponível:

http://webcache.googleusercontent.com/search?q=cache:1YjM_BpTSEkJ:proteus.bro wn.edu/materialworlds/admin/download.html\%3Fattachid\%3D1307635+\&cd=1\&hl= pt-BR\&ct=clnk\&gl=br. Acesso em: 12 de dezembro de 2013.

.Technology's links and chaînes: the processual unfolding of technique and technician. In: DOBRES, Marcia-Anne; HOFFMAN, Christopher (eds.). The Social Dynamics of Technology. Practices, Politics and World Views. Practices Politics and World Views. Washington, DC: Smithsonian Institution Press, 1999.

.HOFFMAN, Christopher. Social Agengy and the Dynamics of Prehistoric Technology. Journal of Archaeological Method and Theory. v.1, n.3, p.211-257, 1994.

DOWSON, Thomas.A. Reading art,writing history: rock art and social change in southern Africa. World Archaeology, v.25, p.332-344, 1994.

DUNNELL, Robert C. Classificação em arqueologia. Traduzido por Astolfo Gomes Mello de Araujo. São Paulo: Edusp, 2007.

. Science, social science, and common sense: The agonizing dilemma of modern archaeology. Journal of Anthropological Research, [s.1]: University of New Mexico, vol. 38, n. 1, p 1-25, 1982. Disponível em: HTTP://www.jstor.org/stable/3629946. Acesso em: 13 de janeiro de 3013 . 
EREMITES DE OLIVEIRA, Jorge; VIANA, Sibele. Pré História da Região Centro Oeste do Brasil. Ciudad Virtual de Antropologia y Arqueologia, 2000. Disponível:HTTP://www.naya.org.ar/congreso2000/ponencias/Jorge_de_Oliveira.htm EVERITT, Brian S; LANDAU, Sabine; LEESE, Morven. Cluster Analysis. London, Oxford University Press, 2001.

FERNANDES, Maria Lourdes Souza. Minerais formadores de rochas. In: SGARBI, Geraldo Norberto Chaves (org). Petrografia Macroscópica das Rochas Ígneas, Sedimentares e Metamórficas. 2 ed,(rev. e ampl.) Belo Horizonte: Editora UFMG, 2012 , p.74-181.

FIGUTI, Levy. Os sítios a céu aberto na Fazenda Verde. In: VIALOU, Águeda Vilhena (org). Pré História do Mato Grosso. Cidade de Pedra. v.2. p. 211-215, 2006.

FOGAÇA, Emilio. Mãos para o Pensamento: a variabilidade tecnológica de indústrias líticas de caçadores coletores holocênicos a partir de um estudo de caso: as camadas VIII e VII da Lapa do Boquete, Minas Gerais. 2001. Tese (Doutorado em Arqueologia), Pontifícia Universidade Católica do Rio Grande do Sul, Porto Alegre, $2001.452 \mathrm{p}$.

. SAMPAIO, Divaldo Rocha; MOLINA, Alberto Luiz. Nas entrelinhas da tradição: os instrumentos de ocasião da Lapa do Boquete (Minas Gerais-Brasil). Revista de Arqueologia. v.10, p. 71-88, 1997.

FONTUGNE, Michel. Cronologia dos Acampamentos. In: VIALOU, Águeda Vilhena; FIGUTI, Levy (orgs), Cidade de Pedra: Passado no Presente. São Paulo: Casa Editorial Maluhy \& Co, 2013. Vol.1. p.47-50.

.;HATTÉ Christine; NOURY Claude. Quadro cronológico. In: VIALOU, Águeda Vilhena (org). Pré história do Mato Grosso. Cidade de Pedra. São Paulo: EDUSP, 2006. v.2. p.45-50.

FURASTÉ, Pedro Augusto. Normas técnicas para o trabalho científico: explicações das normas da ABNT. 16.ed. Porto Alegre: Dáctilo Plus, 2012.

GIFFORD, GONZALEZ, Diane. The third dimension in site structure: an experiment in trampling and vertical dispersal. American Antiquity, Vol 50, n.4 (oct, 1985), pp.803-818.

GOODMAN, Mary Ellen. The Physical Properties of Stone Tool Materials. In: ODELL, George H (org). Archaeological Lithic Analysis: Readings from American Antiquity 
and Latin American Antiquity. Washington, D.C.: Society for American Archaeology, 2009.

GOMBRICH, Ernst Hans. Arte e ilusão: um estudo da psicologia da representação pictória. Tradução de Raul de Sá Barbosa; revisão de Monica Stahel. 3.ed. São Paulo, Martins Fontes, 1995.

HALL, Simon; SMITH, Ben. Empowering places: Rock Shelters and ritual control in farmerforager interactions in the northern province. South African Archaeological Society. Goodwin Series, v. 8, African Naissance; The Limpopo Valley 1000 years ago, dez, 2000.

Disponível: http://www.jstor.org/stable/3858044. Acesso em: 26 de janeiro de 2011.

HARIDASAN, M. Observations on soils, foliar nutrient concentrations and floristic composition of cerrado sensu stricto and cerradão communities in central Brazil, In: FURLEY, P.A., PROCTOR, J., RATTER, J.A (eds). Nature and Dynamics of Forest - Savanna Boundaries. Chapman \& Hall, 2-6, 1992. p. 171-184.

HARRIS, Edward C. Principles of archaeological stratigraphy. London: Academic Press, 1989.

HOFMAN, JACK L. Putting the pieces together: An introduction to refitting. In: HOFMAN Jack L.; ENLOE James G (eds). Piecing together in the past: Applications of refitting studies in archaeology. Bar International Series 578, 1992.

HORTA, Andrei Isnardis. Entre as Pedras: As Ocupações Pré Históricas Recentes e os Grafismos Rupestres da Região de Diamantina, Minas Gerais. 2009. 250 f. Tese (Doutorado em Arqueologia) Museu de Arqueologia e Etnologia, Universidade de São Paulo, São Paulo, 2009.

;; BUENO, Lucas (orgs). Das pedras aos homens: tecnologia lítica na arqueologia brasileira. Belo Horizonte: Argvmetuvm, 2007.

INGOLD, Tim. Beyond art and technology: The anthropology of skill. In: SCHIFFER, Michael Brian (ed). Anthropological perspective on technology. University of New Mexico Press, p. 17-31, 2001.

JONES, Andy M. Regionality in prehistory: some thoughts from the periphery. In: Beyond the core: Reflections on regionality in prehistory. JONES, Andy M. and KIRKHAM, Graeme, (eds). Oxford, UK: Oxbow Books, 2011. 
KAPLAN, Stephen. Perceptions and Landscape: Conceptions and Misconceptions. In Nasar Jack L (ed.) Environmental aesthetics: Theory, research and application. New York: Cambridge University Press, 1992.

KAPLAN, Rachel; KAPLAN, Stephen; RYAN Robert L. With People in the Mind: Design and Management of Everyday Nature. Washington DC, Island Press, 1998.

KAIMAZ, Isil Cakci. Landscape perception. In: OZYAVUZ, Murat (ed.). Landscape planning. [s.1.]: Intech, 2012. [Under CCBY 3.0 license]. p. 251-276.

Disponível: $\quad$ http://www.intechopen.com/books/landscape-planning/landscapeperception. Acesso em: 13 de fevereiro de 2014.

KOBIYAMA, Masato. Conceitos de Zona Ripária e seus Aspectos Geohidrológicos. I Seminário de Hidrologia Florestal, 1., 2003, Florianópolis. Zonas Ripárias, Anais, Florianópolis: UFSC/PPGEA,2003, p.1-13

KIPNIS, Renato. Hunter- Gatherers perspectives from Central Brazil. Antiquity, v.72, n.277, p. $581-592,1998$

LACERDA FILHO, Joffre Valmório de (org). et al. Carta Geológica: Geologia e Recursos Minerais do Estado do Mato Grosso. Escala 1:10000000. Goiânia: CPRM, 2004.

Disponível: http://www.ufrgs.br/igeo/pesquisas/3302/06-3302.pdf. Acesso em: 24 de outubro de 2013.

LANDIM, Paulo M. Barbosa; MONTEIRO, Rubens Caldeira; CORSI, Alessandra Cristina. Introdução à confecção de mapas pelo software SURFER. Texto Didático. Departamento de Geologia Aplicada - IGCE, Unesp, Rio Claro, 2002.

Disponível: $\quad$ www.rc.unesp.br/igce/aplicada/DIDATICOS/LANDIM/Surfer.pdf Acesso em: 28 de maio de 2012.

LEDRU, Marie -Pierre; LABOURIAU, Maria Lea. Salgado; LORSCHEITTER, Maria Luisa. Vegetation dynamics in southern and central Brazil during the last 10.000 yr B.P. Review of Palaebotany and Palynology, [s.1]: Elsevier, v. 99, Issue 2, p. 131-142, 1998.

LEMONNIER, Pierre. Elements for an Anthropology of Technology. An Arbor, Mich: Museum of Anthropology, University of Michigan, 1992.

LEROI-GOURHAN, André. O gesto e a palavra: técnica e linguagem. Paris: Editions Albin Michel, 1964/1965 [1971]. v.1

. O gesto e a palavra: a linguagem e os ritmos. Paris: Editions Albin Michel. 1964/65. [1971] . v.2 
LONGMAN, Keneth Alan; JENÍK, Jan. Forest-Savanna boundaries: general considerations. In: FURLEY, P.A., PROCTOR, J., RATTER, J.A (eds). Nature and Dynamics of Forest - Savanna Boundaries. London: Chapman \& Hall, 1992.

LUCENA, Velena. Estratigrafia arqueológica: Processo de constituição e interpretação. Revista Clio. v.1, n.8, p.69-88, 1992.

Disponível: https://www.ufpe.br/clioarq/images/documentos/1992-N8/1992a3.pdf. Data de acesso: 20 de novembro de 2014.

LOURDEAU, Antonie. Le technocomplexe Itaparica. Définition Techno-functionelle des industries à pieces façonnées unifacialement à une face plane dans le centre et le nordest du Brésil pendant la transition Pléistocène- Holocène ancient. Tese (Doutorado em pré história), 2010. Paris Ouest Nanterre, Nanterre, 2010.

Disponível: https://bdr.u-paris10.fr/theses/internet/2010PA100190.pdf. Acesso em: 20 de agosto de 2014.

.A pertinência de uma abordagem tecnológica para o estudo do povoamento pré histórico do planalto central do Brasil. Habitus, Goiânia.v.4, n.2. p. 685-710. jul/dez.2006.

Disponível em: http://seer.ucg.br/index.php/habitus/article/viewFile/197/158 Acesso em: 15 de julho de 2013.

LOWENTHAL, David (Ed.). Environmental perception and behavior. Chicago: University of Chicago, Department of Geography, 1967.

MADRIGAL, Lorena. Statistics for Anthropology. Cambridge: Cambridge University Press, 1998.

MARTINS Gilson, Rodolfo, KASHIMOTO, Emilia Mariko. 12.000 anos: Arqueologia do Povoamento Humano no Nordeste de Mato Grosso do Sul. Campo Grande, Mato Grosso do Sul: Campo Grande, MS: Life Editora, 2012.

MELLO, Paulo Jobim de Campos. Análise de sistemas de produção e da variabilidade tecnofuncional de instrumentos retocados. As indústrias líticas a céu aberto do rio Manso (Mato Grosso, Brasil). 2005. Tese (Doutorado em Arqueologia). Pontifícia Universidade Católica do Rio Grande do Sul, Porto Alegre, 2005. 2v.

MILlER JUNIOR, Tom. Onde estão as Lascas? Revista Clio Arqueológica, n.24, vol.2, 2009.

. Arqueologia da região central do estado de São Paulo. Dédalo. v.16, .13-118, 1972 
MOORE, Jerry D. The Archaeology of Plazas and the proxemics of ritual. Three Andean Traditions. American Anthropologist. v. 98, n.4, 1996. p.789-802.

MONTEIRO, Luciane Cabral. Abrigos e aldeias: análise dos contextos tecnológicos das ocupações de ceramistas na Cidade de Pedra, Rondonópolis, Mato Grosso. 2005. 164 f. Dissertação (Mestrado em Arqueologia), Museu de Arqueologia e Etnologia da Universidade de São Paulo, São Paulo, 2005.

MORAIS, Carlos Mesquita. Escalas de Medida, Estatística Descritiva e Inferência Estatística. Escola Superior de Educação Instituto Politécnico de Bragança, Bragança, 2005.

Disponível:https://bibliotecadigital.ipb.pt/bitstream/10198/7325/1/estdescr.pdf Acesso em: 04 de janeiro de 2014.

NÁPOLIS, Patricia Maria Martins. Políticas públicas na bacia hidrográfica do rio das Mortes Mato Grosso- Brasil: Educação ambiental para vidas. 2010. 144 f. Tese (Doutorado em Ecologia e Recursos Naturais), Universidade Federal de São Carlos, 2010.

Disponível: www.bdtd.ufscar.br/htdocs/tedeSimplificado/tde_arquivos/2/TDE-201007-30T093417Z-3179/Publico/3118.pdf. Data de acesso: 15 de fevereiro de 2013.

NARDES, Antonia Marília Medeiros. Caracterização e zoneamento ambiental da reserva particular do patrimônio natural Parque Ecológico João Basso. 2005. 84f..Tese (Doutorado em Ecologia e Recursos Naturais), Universidade Federal de São Carlos, São Paulo, 2005.

Disponível:

www.bdtd.ufscar.br/htdocs/tedeSimplificado/tde_busca/arquivo.php?codArquivo=852 . Acesso em: 4 de janeiro de 2013

OLIVEIRA, Ana Paula de Paula Lourer, ROCHA, Cezar Henrique Barra; MENZONI, Mauro; AZEVEDO, FURTADO, Fabricio Cassaro. Análise espacial do sítio arqueológico Córrego do Maranhão. In: Congresso Brasileiro do Cadastro Técnico Multifinalitário - COBRAC 2008. Florianópolis: UFSC. p.1-9.

Disponível: http://www.ufjf.br/maea/files/2010/04/COBRAC2008fabricio.pdf. Acesso em: 14 de março de 2013.

OLIVEIRA FILHO, Ary Teixeira de; MARTINS, Fernando Roberto. A comparative study of five cerrado áreas in southern Mato Grosso, Brazil. Edinburgh Journal of Botany. v. 48, n.3, p.307-332, 1991. 
Disponível: http://journals.cambridge.org/article_S0960428600003036 . Acesso em 25 de outubro de 2012.

OLVEIRA-FILHO, Ary. Teixeira de.; RATTER, James. A. Vegetation physiognomies and woody flora of the cerrado biome. In: OLIVEIRA, Paulo S \& MARQUIS, Roberto, J (eds). The cerrados of Brazil. Ecology and Natural History of a Neotropical Savanna. New York: Columbia University Press, 2002. p 91-113.

PAILLET, Patrick. Abrigos Vermelhos. In: VIALOU, Águeda Vilhena (org). Pré história do Mato Grosso. Cidade de Pedra. São Paulo: EDUSP, 2006. p. 91-124. v.2.

PALLESTRINI, Luciana; PERASSO, Antonio. Arqueologia: Metodo y técnicas em superfícies amplias. Biblioteca Paraguaya de Antropología. Centro de Estudios Antropológicos. Universidade Católica, 1984.

PARRY, William J; KELLY, Robert. L. Expedient core technology and sedentism. In: Johnson, Jay. K., MORROW Carol, A. (eds.). The Organization of Core Technology. Boulder, Colorado: Westview Press, 1987. p. 285-304.

PEREIRA, Edithe da Silva. Arte rupestre na Amazônia - Pará. Belém: Museu Paraense Emílio Goeldi. São Paulo, Editora da UNESP. 2003

PINTO, Maria Novaes. Geomorfologia do Pantanal Mato-grossense. In: SIMPÓSIO BRASILEIRO DE SENSORIAMENTO REMOTO,5, 1988, Brasília, DF. Anais. São José dos Campos: INPE, 1988, p.78-85.

Disponível:

http://marte.dpi.inpe.br/col/dpi.inpe.br/marte@ 80/2008/07.22.19.16/doc/078-085.pdf. Acesso em: 12 de março de 2013.

PROUS, André. O Brasil antes dos brasileiros. A pré história do nosso país. Segunda edição revisada, Rio de Janeiro: Jorge Zahar, 2007.

. O povoamento da América visto do Brasil: uma perspectiva crítica. Revista USP, São Paulo, n.34, p.8-21, junho/agosto,1997

Disponível em: http://www.usp.br/revistausp/34/02-andre.pdf Acesso em: 01 de junho de 2013. . Os artefatos líticos. Elementos descritivos classificatórios. In: Arquivos do Museu de História Natural da Universidade Federal de Minas Gerais, Belo Horizonte, v. XI, 1986-1990, p. 1-88. 
; ALONSO, Márcio. A tecnologia de debitagem do quartzo no centro de Minas Gerais: Lascamento Bipolar. In: Arquivos do Museu de História Natural da Universidade Federal de Minas Gerais, Belo Horizonte, v. XI, 1986-1990.

. Fouilles Du Grand Abri de Santana de Riacho (Minas Gerais), Brésil. Journal de la Societé des Américanistes, Paris, n.67, p.63-183, 1980.

Disponível:http://www.persee.fr/web/revues/home/prescript/article/jsa_0037-

9174_1980_num_67_1_2192. Acesso em: em 14 de fevereiro de 2014.

RATTER, James A. Transitions between Cerrado and Forest Vegetation in Brazil. In: FURLEY, P.A., PROCTOR, J., RATTER, J.A (eds). Nature and Dynamics of Forest - Savanna Boundaries. London New York: Chapman \& Hall, 1992.

RICK, John W. Downslope movement and archaeological intrasite spatial analysis. American Antiquity. v.41, n.2, p. 133-146, 1976.

ROBRAHN GONZALEZ, Erika Marion. A ocupação ceramista pré colonial no Brasil Central: origens e desenvolvimento. 1996. 279 f. Tese (Doutorado em Arqueologia), Faculdade de Filosofia, Letras e Ciências Humanas, Universidade de São Paulo, São Paulo, 1996.

RODET, Maria Jaqueline. Etude technologique des industries lithiques taillées du nord de Minas Gerais, Brésil: depuis le passage Plèistocéne/Holocène jusqu'au contact XVIIIème siècle. 2006. 516 p. Thèse (Doctorat en Préhistoire), Université de Paris X, Nanterre, Paris X, França. 2006.

- ALONSO, Márcio. Princípios de reconhecimento de duas técnicas de debitagem: percussão direta dura e percussão direta macia (tendre). Experimentação com material do norte de MG. Revista de Arqueologia, Porto Alegre, n.17: 63-72, 2004.

Disponível: http://periodicos.ufpb.br/ojs/index.php/ra/article/view/1525. Acesso em: 14 de dezembro de 2012.

ROOSEVELT, Anna.C et al. Paleoindian Cave Dwellers in the Amazon: The peopling of the Americas. Science. v. 272, p.373-384, 1996.

ROSS, Jurandyr Luciano Sanches (org). Geografia do Brasil. 5 edição revista e ampliada. São Paulo: EDUSP, 1995. . Registro cartográfico dos fatos geomorfológicos e a questão da taxonomia do relevo.

Revista do Departamento de Geografia. São Paulo. v. 6, p. 17-29, 1992.

Disponível:http://citrus.uspnet.usp.br/rdg/ojs/index.php/rdg/article/view/245/224.

Acesso em: 20 de outubro de 2012. 
O contexto geotectônico e a morfogênese da província serrana de Mato Grosso. Revista do Instituto Geológico, São Paulo, vol. 12, n.1/2, p. 21-37, jan/dez, 1991.

Disponível em: http://ppegeo.igc.usp.br/pdf/rig/v12n1-2/v12n1-2a02.pdf Acesso em: 3 de agosto de 2013

SANTANA-PORTO, Eucilene Alves. et al. Identificação macroscópica das gônadas de peixes de interesse comercial no período de piracema em três afluentes do rio Cuiabá, baixa do alto Paraguai, município de Rondonópolis, Mato Grosso, Brasil, 2005. Caxambu. In: CONGRESSO DE ECOLOGIA DO BRASIL, 7, 2005, Caxambu, MG. Livro de Resumo Expandido, 2005.

Disponível: http://www.seb-ecologia.org.br/viiceb/resumos/286a.pdf Acesso em: 15 de abril de 2013

SCHIFFER, Michael Brian. et. al. Behavioral Archaeology. Principles and Practice. London Oakville, Equinox Publishing Ltd, 2010.

SCHMITZ, Pedro Ignácio; ROSA, André Osório; BITENCOURT, Ana Luisa Vietti. Arqueologia nos cerrados do Brasil Central: Serranópolis III. Pesquisas, Série Antropologia, São Leopoldo, RS: Instituto Anchietano de Pesquisas, n.60, 2004.

.Caçadores antigos no sudoeste de Goiás, Brasil. Estudios Atacamenõs. Chile: Universidade del Norte, San Pedro de Atacama, n. 8, p.16-35, 1987.

;Caiapônia: Arqueologia nos Cerrados do Brasil Central. RS. Instituto Anchietano de Pesquisas, Unisinos. 1986. (Publicações avulsas, n.8).

. La evolucíon de la cultura em el centro y nordeste de Brasil em 14.000 y 4.000 antes del presente. Pesquisas (série antropológica), v.32, p.7-39, 1981.

SGARBI, Geraldo Norberto Chaves (org). Petrografia Macroscópica das Rochas Ígneas, Sedimentares e Metamórficas. 2 ed, revisada e ampliada. Belo Horizonte: Editora UFMG, 2012.

SILVA, Carolina Joana.; SILVA, Joana Fernandes. No ritmo das águas do Pantanal. São Paulo, NUPAUB-USP, 1995.

SILVA, Valéria Cristina Ferreira. Geologia e Litologia. In: VIALOU, Águeda Vilhena; FIGUTI, Levy (orgs). Cidade de Pedra: Passado no Presente. São Paulo: Casa Editorial Maluhy \& Co, 2013. p.27-29.

A Exploração dos Recursos litológicos da Cidade de 99 f. 2005. Dissertação (Mestrado em Arqueologia), Museu de Arqueologia e Etnologia, Universidade de São Paulo, São Paulo, 2005. 
SILVA, João Santos Vila; ABDON, Myriam de Moura. Delimitação do Pantanal Brasileiro e suas Sub Regiões. Pesquisas. Agropecuária Brasileira, DF, v. 33, p. 1703-1711, maio1998. (Número Especial).

SHOTT, Michael. An exegesis of the curation concept. Journal of Anthropological Research, v. 52, n.3,1996. p.259-280.

. Settlement mobility and technological organization: an ethnographic examination.

Journal of Anthropological Research. v. 42, 1986. p.15-51.

Disponívelem:

http://www.jstor.org/discover/10.2307/3630378?uid=2129\&uid=2\&uid=70\&uid=4\&si $\mathrm{d}=21105218195373$. Acesso em: 24 de maio de 2013.

SORESSI, Marie; GINESTE, Jean-Michel. Special Issue: Reduction sequencie, chaîne opératoire, and others methods: The epistemologies of different approaches to lithic analysis. PaleoAntropology. 2011, p.334-350.

Disponível: www.paleoanthro.org/static/.../PA20110334.pdf. Acesso em: 21 de janeiro de 2013.

STEIN, Julie K. Scale in archaeology, geosciences, and geoarchaeology. In: STEIN, Julie K; LINSE, Angela R. (eds). Effects of scale an archaeological and geoscientific perspectives. Boulder, Colorado: Geological Society of America, 1993. p. 1-10. (Special Paper, 283).

STOCKTON, Eugene D. Shaw's Creek Shelter: Human Displacement of Artefacts and its significance. Mankind, 9, 1973. P. 112-117.

SUGUIO, Kenitiro. Rochas sedimentares: propriedades, gênese, importância econômica. São Paulo: E. Blucher, Universidade de São Paulo, 1980.

SUllivAN, Alan P; ROZEN, Kenneth C. Debitage analysis and archaeological interpretation. In: ODELL, George H. (org). Archaeological lithic analysis: readings from American Antiquity and Latin American Antiquity. Washington, Society for American Archaeology, The SAA Press, 2009. p.307-331.

TANNUS, Rafael Nora. Funcionalidade e Sazonalidade sobre Cerrado e sobre FlorestaEcótono Cerrado: uma investigação com dados micrometeorológicos e $\mathrm{CO}_{2}$. Dissertação (Mestrado em Ecologia de Ecossistemas). 2004. 94 f. Escola Superior de Agricultura Luiz de Queiroz, Piracicaba, SP, 2004.

TILLEY, Christopher; HAMILTON, Sue; HARRISON, Stephan; ANDERSON, An. Nature, Culture, Clitter. Distinguishing between cultural and geomorphological landscapes; 
The case of Hilltop Tors in south-west England. Journal of Material Culture. v.5, n.197, p. 197-224, 2000.

Disponível: http://mcu.sagepub.com. Acesso em: 2 de fevereiro de 2013.

TIXIER, Jacques.; INIZAN, Marie-Louise.; ROCHE, Hélène. Technology of Knapped Stone. Préhistoire de la Pierre Taillé. Paris, Cercle de recherches et d’études préhistoriques, 1992.

TOLEDO, Eduardo Vilhena de. Três décadas de prospecção na Cidade de Pedra. In: VALOU, Águeda Vilhena; FIGUTI, Levy (orgs). Cidade de Pedra:Passado e Presente. São Paulo: Casa Editorial Maluhy \& Co, 2013.

., Prospecção. In: VIALOU, Águeda Vilhena (org). Pré história do Mato Grosso. Cidade de Pedra. São Paulo: EDUSP, 2006. v.2. p. 27-32.

TOMKA, Steven A. The effect of processing requirements on reduction strategies and tool form: a new perspective. In: ANDREFSKY JUNIOR, William (ed.). Lithic debitage analysis: Context, Form, Meaning. Salt Lake City: University of Utah Press, 2001. p. 207-225.

;CAMERON, C.M (eds). Abandonment of settlements and region ethnoarchaeological and archaeological approach. Cambridge, Cambridge Press, 1993.

THORP, C.R. A preliminar report on evidence of interaction between Hunter-gatherers and farmers along a hypothesized frontier in the eastern free state. South African Archaeological Bulletin v. 51, 1996. p. 57-63.

Disponível em: http://www.jstor.org/stable/3888840. Data de Acesso: 25 de outubro de 2013.

TRIGGER, Bruce G. A history of Archaeological Thought. Cambridge New York, Cambridge University Press, 1989.

TUAN, Yi Fu. Espaço e Lugar. A perspectiva da experiência. Tradução de Lívia de Oliveira. São Paulo: DIFEL, 1983.

TURKMAN, Maria Antónia Amaral; SILVA, Giovani Loiola. Modelos Lineares Generalizados - da teoria à prática. Lisboa: Editions SPE, 2000.

Disponível em: http://docentes.deio.fc.ul.pt/maturkman/mlg.pdf. Acesso em: 24 de outubro de 2014.

TURNER, Victor Witter. The anthropology of performance. New York: PAJ Publications, 1988. 
VAN DYKE, Ruth M.; ALCOCK, Susan E. Archaeologies of Memory. Blackwell Publishing, Oxford, 2003

VAN DOORNUM, Bronwen. Sheltered from change: hunter-gatherer occupation of Balerno Main Shelter, Shashe-Limpopo confluence area, South Africa. Southern African Humanities, vol. 20, p.249-284, December, 2008.

Disponível: http://www.sahumanities.org/ojs/index.php/SAH/article/viewFile/243/202. Acesso em 20 de agosto de 2014.

. Tshisiku Shelter and the Shashe-Limpopo confluence area hunter-gatherer sequence. Southern African Humanities, vol.19, p.17-67 December, 2007.

Disponível: http://www.sahumanities.org/ojs/index.php/SAH/article/viewFile/218/177 Acesso em 02 de agosto de 2014.

VIALOU, Águeda Vilhena; FIGUTI, Levy. Sítios Habitacionais e Povoamentos Pré Históricos. In: VIALOU, Águeda Vilhena; FIGUTI, Levy (orgs). Cidade de Pedra: Passado no Presente. São Paulo: Casa Editorial Maluhy \& Co, 2013.

. A indústria lítica de Ferraz Egreja. In: VIALOU, Águeda Vilhena (org). Pré História do Mato Grosso. Cidade de Pedra. v.2. EDUSP, p. 169-183.São Paulo, 2006.

. Territórios, meio ambiente e culturas pré históricas na Cidade de Pedra, Mato Grosso. In: Congresso Internacional da Sociedade Brasileira, [SAB], 12, Arqueologia das Américas, 2003. Anais. São Paulo, SAB, Sociedade de Arqueologia Brasileira, 2003. $\mathrm{S} / \mathrm{p}$.

.Tecno-Tipologia das indústrias líticas do sítio Almeida em seu quadro natural, arqueoetnológico e regional. Museu Paulista, Instituto de Pré História, Universidade de São Paulo, São Paulo, 1980.

VIALOU, Denis. A arte rupestre na Cidade de Pedra. In: In: VIALOU, Águeda Vilhena; FIGUTI, Levy (orgs). Cidade de Pedra: Passado no Presente. São Paulo: Casa Editorial Maluhy \& Co, 2013. p.31-34.

. A arte rupestre e a paisagem da Cidade de Pedra In: VIALOU, Águeda Vilhena (org). Pré história do Mato Grosso. Cidade de Pedra. São Paulo: EDUSP, v.2. p.51-70, 2006.

. Art rupestre, habitats et territories au Brésil. El arte pré-histórico desde los inicios del siglo XXI. Primer Symposium Internacional de Arte Prehistórico de Ribadesella. Asociación Cultural Amigos de Ribadesella, 2003. Asturias: Asociación Cultural de Ribadesella, 2003. P. 481-512. 
; et. al. O Homem Fóssil e seus Paleoambientes na Bacia do Paraná. Relatório de missão, 1992.

.; O Homem Fóssil e seus Paleoambientes na Bacia do Paraná. Relatório de missão, 1993.

.; O Homem Fóssil e seus Paleoambientes na Bacia do Paraná. Relatório de missão, 1994.

.; O Homem Fóssil e seus Paleoambientes na Bacia do Paraná. Relatório de missão, 1995.

.; O Homem Fóssil e seus Paleoambientes na Bacia do Paraná. Relatório de missão, 1997.

.; O Homem Fóssil e seus Paleoambientes na Bacia do Paraná. Relatório de missão, 1999.

VIANA, Sibeli Aparecida. Instrumentos fora de seus contextos de produção. Instrumentos líticos plano convexos provenientes de sítios lito cerâmicos do estado do Mato Grosso.

Habitus, Goiânia, v. 9, n.1, p.101-131, jan/jun, 2011.

Disponível em http://seer.ucg.br/index.php/habitus/article/view/2212/1368 Acesso em 03 de março de 2014.

- Variabilidade tecnológica do sistema de debitagem de confecção dos instrumentos líticos lascados de sítios lito-cerâmico da região de rio Manso, MT. Tese (Doutorado em História) PUC/RS, 2005.

VIDOTTO, Elaine. Estudo da dinâmica do ecótono floresta-campo no sul do estado do Amazonas no Quaternário tardio, empregando os isótopos do carbono e das plantas. Dissertação (Mestrado Acadêmico). 2003. 101 f. Escola Superior de Agronomia Luiz de Queiroz, Piracicaba, 2003.

VILLA, Paola; COURTIN, Jean. The interpretation of stratifield sites: a view from underground. Journal of Archaeological Science. Vol 10, 1983, pp. 267-281.

. Conjoinable pieces and site formation process. American Antiquity. v.47, n.2, p. 277-287, 1982.

WARD JUNIOR, Joe H. Hierarchical grouping to optimize an objective function.

Journal of the American Statistical Association. vol, 58, n. 301, p. 236-244, março,1963. Disponível em: http://www.jstor.org/stable/2282967. Acesso em: 13 de setembro de 2012. 
WARGO, Melissa Candy. The Bordes Binford debate: translation in interpretative traditions in paleolithic archaeology. 2009. 151 f. Tese (Doctor in Philosophy), Universidade do Texas e Arlington, Texas, 2009.

Disponível:

www.ibrarian.net\%2Fnavon\%2Fpaper\%2FTHE_BORDES_BINFORD_DEBATE_T RANSATLANTIC_INTERPRE.pdf. Acesso em: 12 de janeiro de 2012

WHEATLEY, David; GILLING Mark. Spatial technology and archaeology: the archaeological application of GIS. New York: Taylor \& Francis, 2002.

WHITTAKER, John C. Flintknapping, making and understanding stone tools. Austin: University of Texas Press, 1996.

WÜST, Irmhild; CARVALHO, Helen B. Novas perspectivas para o estudo dos ceramistas pré-coloniais do Centro-oeste brasileiro: a análise espacial do sítio Guará 1 (GO-NI100), Goiás. Revista do Museu de Arqueologia e Etnologia da Universidade de São Paulo v.6, n. 47, p.47-81, 1996.

. Continuidade e Mudança: Para uma Interpretação dos Grupos Ceramistas Pré coloniais da Bacia do Rio Vermelho, Mato Grosso. 1990. 683 f. Tese (Doutorado em Antropologia), Faculdade de Filosofia, Letras e Ciências Humanas, Universidade de São Paulo, São Paulo, 1990.

ZEDEÑO, María Nieves; STOFLE, Richard W. Tracking the role of pathways in the evolution of a human landscape. The St. Croix riverway in ethnohistorical perspective. Colonization of unfamiliar landscapes. The archaeology of adaptation. ROCKMAN, Marcy \& STEELE, James(eds). Routledge, London: Routledge, 2003. P.59-80.

.On what people make of places. A behavioral cartography. In: Social theory in archaeology. SCHIFFER, Michael Brian (Ed). Salt Lake City: University of Utah Press, 2000.(Foundations of Archaeological Inquiry). P.97-11. 


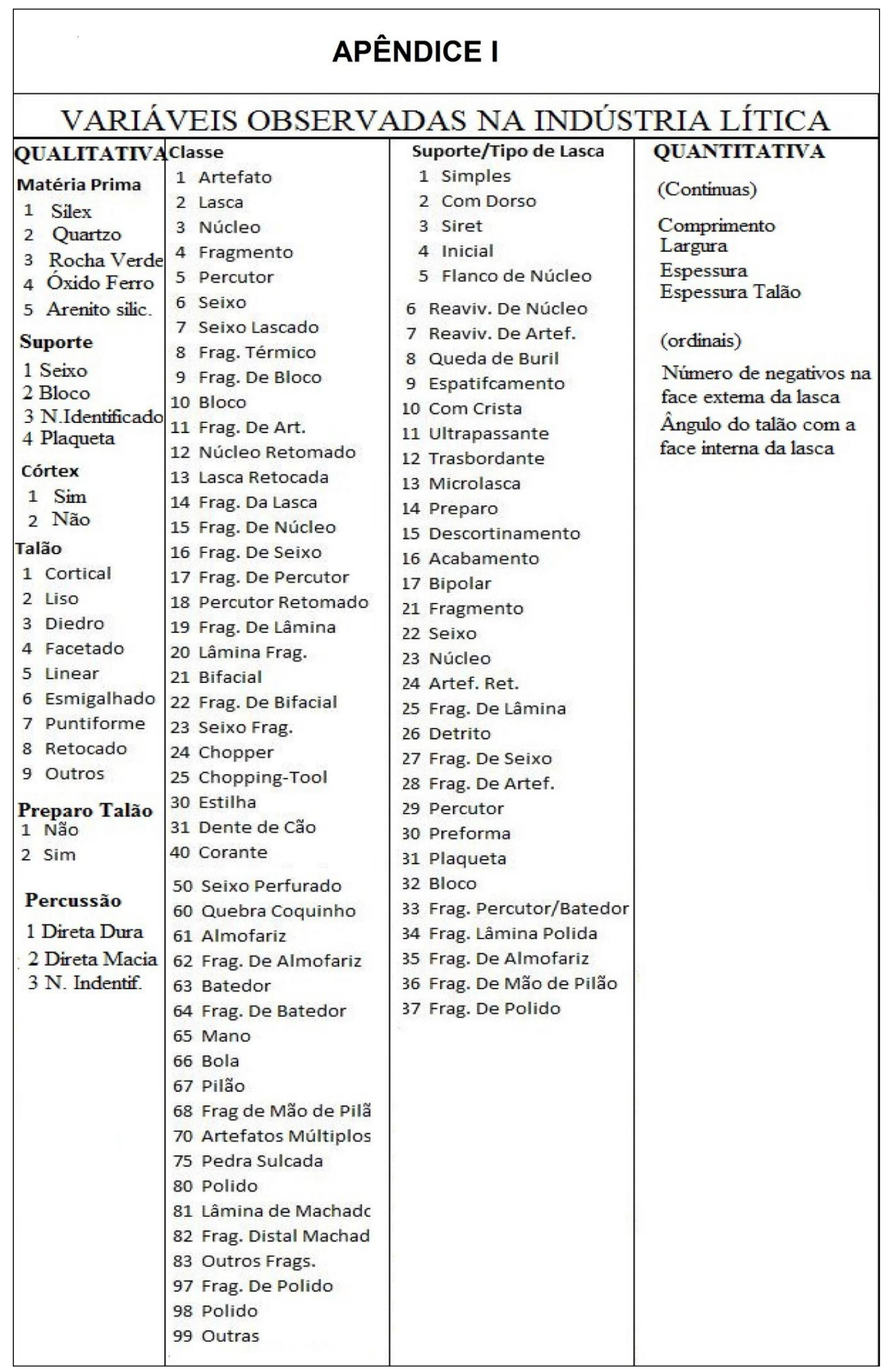




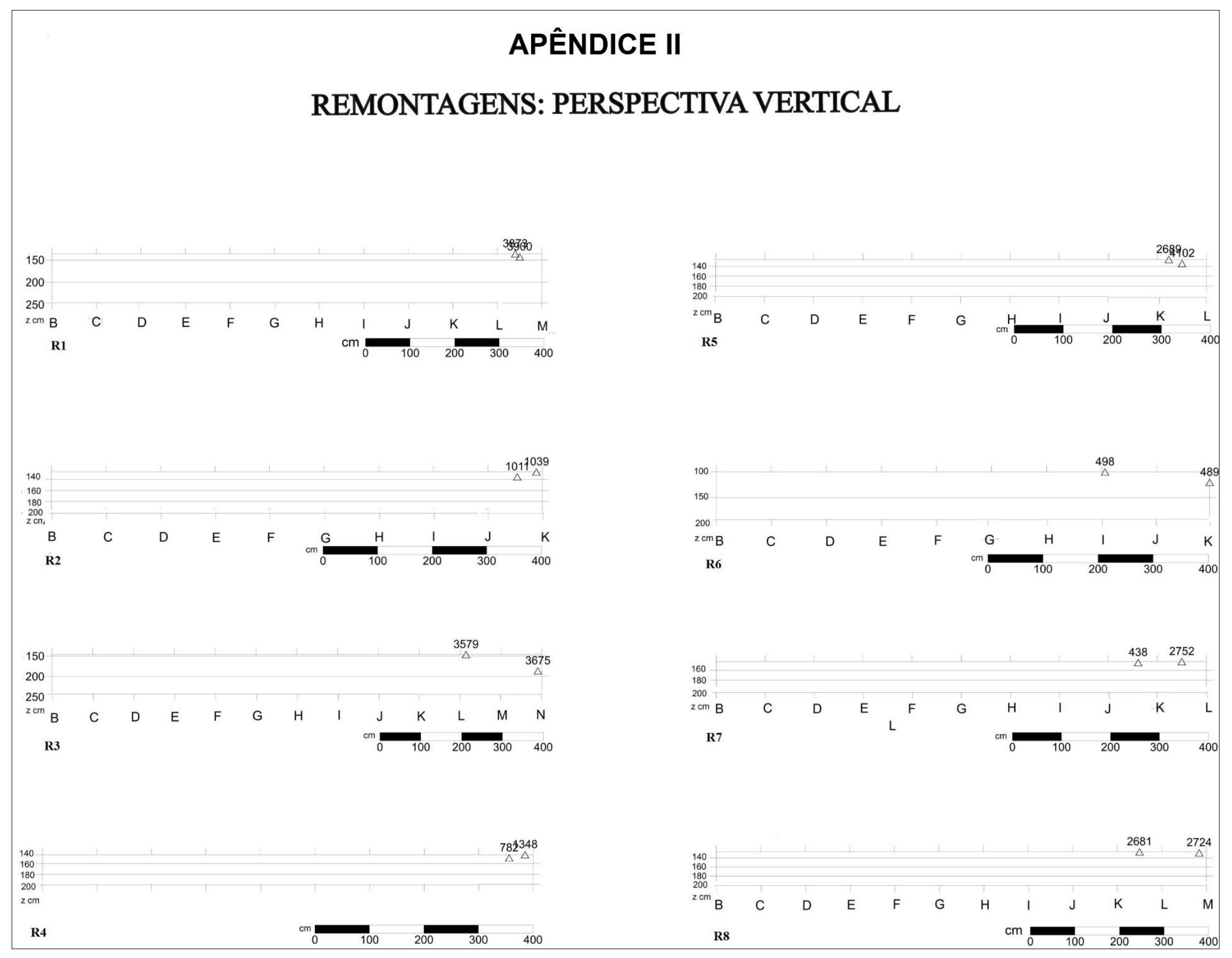




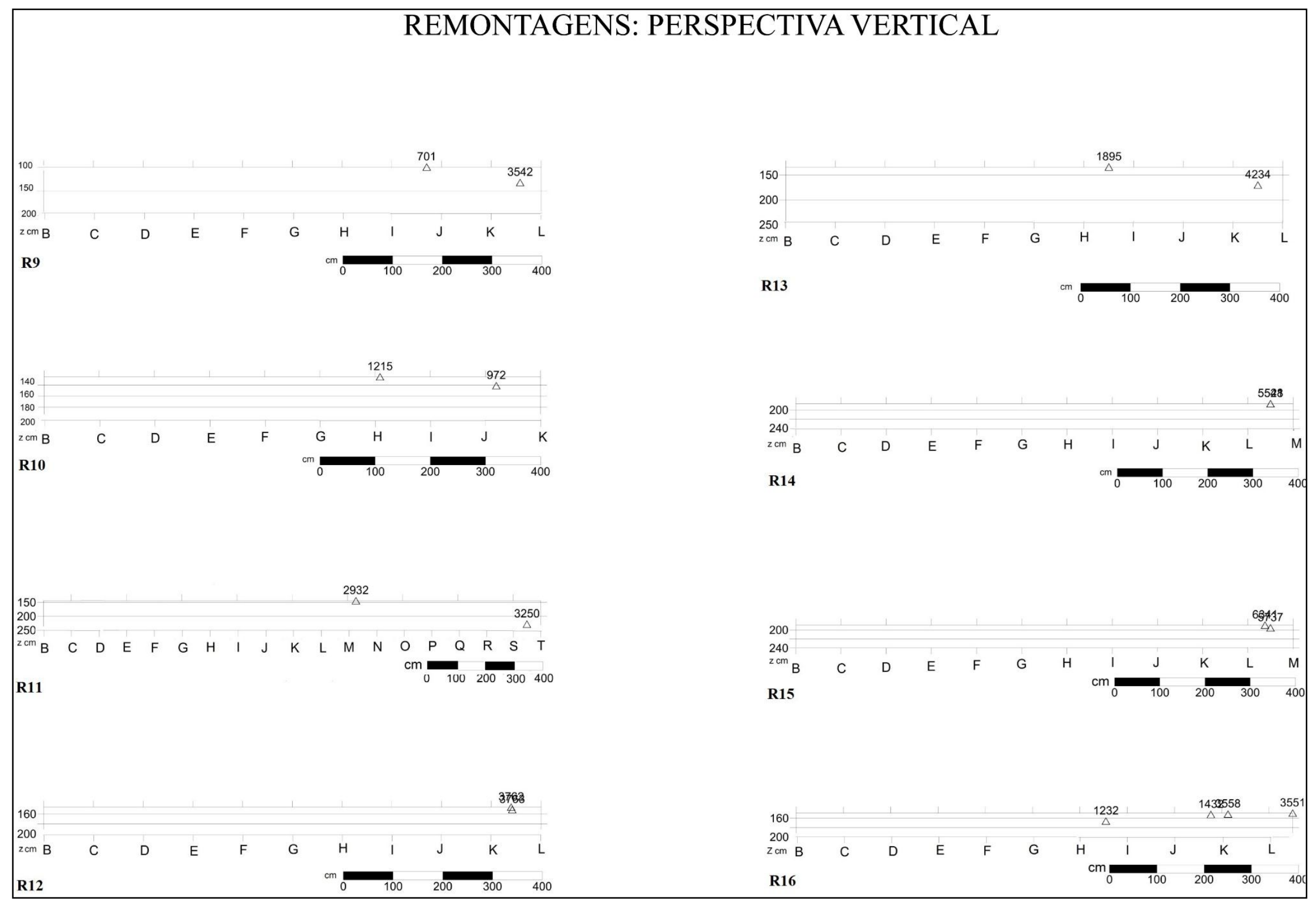




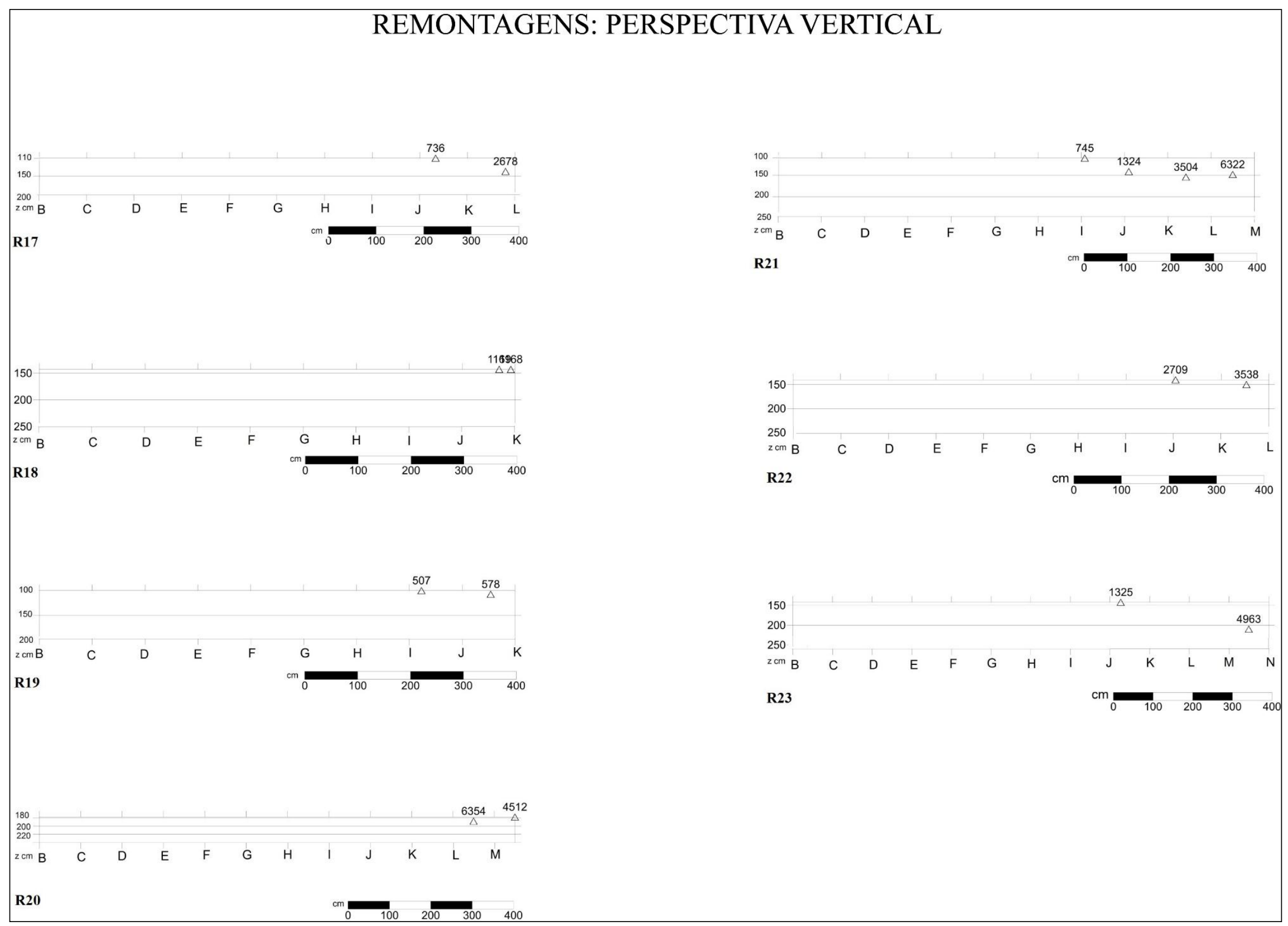




\section{APÊNDICE 3 - FREQUÊNCIAS TECNOLÓGICAS DOS CONJUNTOS LÍTICOS}

\section{Conjunto 1 - Sílex}

Tabela 1 - Suporte

Suporte

\begin{tabular}{|l|r|r|r|r|}
\hline & Frequência & Porcentual & $\begin{array}{c}\text { Porcentagem } \\
\text { válida }\end{array}$ & $\begin{array}{c}\text { Porcentagem } \\
\text { acumulativa }\end{array}$ \\
\hline Válido Seixo & 450 & 100,0 & 100,0 & 100,0 \\
\hline
\end{tabular}

Tabela 2 - Córtex

Córtex

\begin{tabular}{|rl|r|r|r|r|}
\hline & Frequência & Porcentual & $\begin{array}{c}\text { Porcentagem } \\
\text { válida }\end{array}$ & $\begin{array}{c}\text { Porcentagem } \\
\text { acumulativa }\end{array}$ \\
\hline Válido & Não & 386 & 85,8 & 85,8 & 85,8 \\
& Sim & 64 & 14,2 & 14,2 & 100,0 \\
& Total & 450 & 100,0 & 100,0 & \\
\hline
\end{tabular}

Tabela 3 - Classes

Classes

\begin{tabular}{|c|c|c|c|c|c|}
\hline & & Frequência & Porcentual & $\begin{array}{l}\text { Porcentagem } \\
\text { válida }\end{array}$ & $\begin{array}{l}\text { Porcentagem } \\
\text { acumulativa }\end{array}$ \\
\hline \multirow[t]{7}{*}{ Válido } & Lasca & 193 & 42,9 & 42,9 & 42,9 \\
\hline & Frag Núcleo & 4 & 9 &, 9 & 43,8 \\
\hline & Fragmento & 102 & 22,7 & 22,7 & 66,4 \\
\hline & Frag Térmico & 11 & 2,4 & 2,4 & 68,9 \\
\hline & Frag de Lasca & 120 & 26,7 & 26,7 & 95,6 \\
\hline & Frag de Seixo & 20 & 4,4 & 4,4 & 100,0 \\
\hline & Total & 450 & 100,0 & 100,0 & \\
\hline
\end{tabular}


Tabela 4 - Classe de Lasca

Classe de Lasca

\begin{tabular}{|ll|r|r|r|r|}
\hline & Frequência & Porcentual & $\begin{array}{c}\text { Porcentagem } \\
\text { válida }\end{array}$ & $\begin{array}{c}\text { Porcentagem } \\
\text { acumulativa }\end{array}$ \\
\hline Válido & Simples & 70 & 15,6 & 36,3 & 36,3 \\
& Com Dorso & 4 &, 9 & 2,1 & 38,3 \\
& Siret & 9 & 2,0 & 4,7 & 43,0 \\
& Inicial & 5 & 1,1 & 2,6 & 45,6 \\
& Flanco de Núcleo & 4 &, 9 & 2,1 & 47,7 \\
& Preparo de Núcleo & 48 & 10,7 & 24,9 & 72,5 \\
& Descorticamento & 28 & 6,2 & 14,5 & 87,0 \\
& Acabamento & 6 & 1,3 & 3,1 & 90,2 \\
& Bipolar & 7 & 1,6 & 3,6 & 93,8 \\
& Retoque & 12 & 2,7 & 6,2 & 100,0 \\
Ausente & Sistema & 193 & 42,9 & 100,0 & \\
Total & 257 & 57,1 & & \\
\hline
\end{tabular}

Tabela 5 - Percussão

Percussão

\begin{tabular}{|ll|r|r|r|r|}
\hline & & & $\begin{array}{c}\text { Porcentagem } \\
\text { válida }\end{array}$ & $\begin{array}{c}\text { Porcentagem } \\
\text { acumulativa }\end{array}$ \\
\hline Válido & Direta Dura & 160 & 35,6 & 82,9 & 82,9 \\
& Direta Macia & 2 &, 4 & 1,0 & 83,9 \\
& Não Identificada & 24 & 5,3 & 12,4 & 96,4 \\
& Bipolar & 7 & 1,6 & 3,6 & 100,0 \\
& Total & 193 & 42,9 & 100,0 & \\
Ausente & Sistema & 257 & 57,1 & & \\
Total & 450 & 100,0 & & \\
\hline
\end{tabular}


Tabela 6 - Preparo de Talão

Preparo de Talão

\begin{tabular}{|ll|r|r|r|r|}
\hline & Frequência & Porcentual & \multicolumn{1}{c|}{$\begin{array}{c}\text { Porcentagem } \\
\text { válida }\end{array}$} & $\begin{array}{c}\text { Porcentagem } \\
\text { acumulativa }\end{array}$ \\
\hline Válido & Sim & 34 & 7,6 & 18,3 & 18,3 \\
& Não & 152 & 33,8 & 81,7 & 100,0 \\
Ausente & Sotal & 186 & 41,3 & 100,0 & \\
Total & & 264 & 58,7 & & \\
\hline
\end{tabular}

Tabela 7 - Classe de Talão

Classe de Talão

\begin{tabular}{|ll|r|r|r|r|}
\hline & Frequência & Porcentual & $\begin{array}{c}\text { Porcentagem } \\
\text { válida }\end{array}$ & $\begin{array}{c}\text { Porcentagem } \\
\text { acumulativa }\end{array}$ \\
\hline Válido & Cortical & 15 & 3,3 & 7,8 & 7,8 \\
& Liso & 131 & 29,1 & 67,9 & 75,6 \\
& Diedro & 5 & 1,1 & 2,6 & 78,2 \\
& Facetado & 8 & 1,8 & 4,1 & 82,4 \\
& Linear & 12 & 2,7 & 6,2 & 88,6 \\
& Esmigalhado & 6 & 1,3 & 3,1 & 91,7 \\
& Puntiforme & 13 & 2,9 & 6,7 & 98,4 \\
& Retocado & 1 &, 2 &, 5 & 99,0 \\
& Outros & 2 &, 4 & 1,0 & 100,0 \\
Ausente & Sistema & 193 & 42,9 & 100,0 & \\
Total & 257 & 57,1 & & \\
\hline
\end{tabular}

Tabela 8 - Espessura do talão

Espessura do talão (mm)

\begin{tabular}{|l|r|r|r|r|r|}
\hline & \multicolumn{1}{|c|}{ N } & Mínimo & Máximo & Média & Desvio Padrão \\
\hline Espessura Talao & 186 & 1 & 20 & 4,51 & 3,257 \\
Válido $N$ & 186 & & & & \\
\hline
\end{tabular}


Tabela 9 - Ângulo do talão com a face interna da lasca

Ângulo do Talão com a face interna da Lasca

\begin{tabular}{|ll|r|r|r|r|}
\hline & Frequência & Porcentual & $\begin{array}{c}\text { Porcentagem } \\
\text { válida }\end{array}$ & $\begin{array}{c}\text { Porcentagem } \\
\text { acumulativa }\end{array}$ \\
\hline Válido & 60,0 & 4 &, 9 & 3,6 & 3,6 \\
& 70,0 & 2 & 4 & 1,8 & 5,5 \\
& 80,0 & 9 & 2,0 & 8,2 & 13,6 \\
& 90,0 & 72 & 16,0 & 65,5 & 79,1 \\
& 100,0 & 12 & 2,7 & 10,9 & 90,0 \\
& 110,0 & 7 & 1,6 & 6,4 & 96,4 \\
& 120,0 & 3 &, 7 & 2,7 & 99,1 \\
& 160,0 & 1 &, 2 &, 9 & 100,0 \\
& Total & 110 & 24,4 & 100,0 & \\
Ausente & Sistema & 340 & 75,6 & & \\
Total & & 450 & 100,0 & & \\
\hline
\end{tabular}

Tabela 10 - Medidas das lascas e fragmentos de lascas

Medidas das Lascas e Frag Lascas

\begin{tabular}{|l|r|r|r|r|r|}
\hline & N & Mínimo & Máximo & \multicolumn{1}{c|}{ Média } & \multicolumn{1}{c|}{$\begin{array}{c}\text { Desvio } \\
\text { padrão }\end{array}$} \\
\hline Comprimento & 313 & 1,0 & 60,0 & 21,018 & 11,2422 \\
Largura & 313 & 2,0 & 75,0 & 17,752 & 10,3602 \\
Espessura & 313 & 1,0 & 33,0 & 7,077 & 4,7241 \\
N válido (de lista) & 313 & & & & \\
\hline
\end{tabular}




\section{Conjunto 2 - Sílex}

Tabela 11- Suporte

Suporte

\begin{tabular}{|ll|r|r|r|r|}
\hline & Frequência & Porcentual & $\begin{array}{c}\text { Porcentagem } \\
\text { válida }\end{array}$ & $\begin{array}{c}\text { Porcentagem } \\
\text { acumulativa }\end{array}$ \\
\hline $\begin{array}{l}\text { Válido } \\
\text { Ausente }\end{array}$ & Seixo & 233 & 91,4 & 100,0 & 100,0 \\
Total & 0 & & & \\
\hline
\end{tabular}

Tabela 12 - Córtex

Córtex

\begin{tabular}{|ll|r|r|r|r|}
\hline & & Frequência & Porcentual & $\begin{array}{c}\text { Porcentagem } \\
\text { válida }\end{array}$ & $\begin{array}{c}\text { Porcentagem } \\
\text { acumulativa }\end{array}$ \\
\hline Válido & Não & 214 & 83,9 & 91,8 & 91,8 \\
& Sim & 19 & 7,5 & 8,2 & 100,0 \\
Tutal & 233 & 91,4 & 100,0 & \\
Total & & & & & \\
\hline
\end{tabular}

Tabela 13 - Classes

\section{Classes}

\begin{tabular}{|ll|r|r|r|r|}
\hline & Frequência & Porcentual & $\begin{array}{c}\text { Porcentagem } \\
\text { válida }\end{array}$ & $\begin{array}{c}\text { Porcentagem } \\
\text { acumulativa }\end{array}$ \\
\hline Válido & Lasca & 129 & 55,4 & 55,4 & 55,4 \\
& Frag Núcleo & 4 & 1,7 & 1,7 & 57,1 \\
Fragmento & 47 & 20,2 & 20,2 & 77,3 \\
Frag Térmico & 5 & 2,1 & 2,1 & 79,4 \\
Frag Lasca & 43 & 18,5 & 18,5 & 97,9 \\
Frag Seixo & 3 & 1,3 & 1,3 & 99,1 \\
Lasca Laminar & 1 &, 4 &, 4 & 99,6 \\
Frag Artefato & 1 &, 4 &, 4 & 100,0 \\
Total & 233 & 100,0 & 100,0 & \\
\hline
\end{tabular}


Tabela 14 - Classe de Lascas

Classes de Lascas

\begin{tabular}{|ll|r|r|r|r|}
\hline & Frequência & Porcentual & $\begin{array}{c}\text { Porcentagem } \\
\text { válida }\end{array}$ & $\begin{array}{c}\text { Porcentagem } \\
\text { acumulativa }\end{array}$ \\
\hline Válido & Simples & 37 & 15,9 & 28,7 & 28,7 \\
& Com Dorso & 2 &, 9 & 1,6 & 30,2 \\
& Siret & 3 & 1,3 & 2,3 & 32,6 \\
& Flanco de Núcleo & 1 &, 4 &, 8 & 33,3 \\
& Reavi. Núcleo & 1 &, 4 &, 8 & 34,1 \\
& Com Crista & 1 &, 4 &, 8 & 34,9 \\
& Preparo de Núcleo & 26 & 11,2 & 20,2 & 55,0 \\
& Descorticamento & 5 & 2,1 & 3,9 & 58,9 \\
& Acabamento & 6 & 2,6 & 4,7 & 63,6 \\
& Bipolar & 6 & 2,6 & 4,7 & 68,2 \\
Ausente & Sistema & 129 & 17,6 & 31,8 & 100,0 \\
Total & Total & 104 & 44,6 & 100,0 & \\
\hline
\end{tabular}

Tabela 15 - Percussão

\section{Percussão}

\begin{tabular}{|ll|r|r|r|r|}
\hline & Frequência & Porcentual & $\begin{array}{c}\text { Porcentagem } \\
\text { válida }\end{array}$ & $\begin{array}{c}\text { Porcentagem } \\
\text { acumulativa }\end{array}$ \\
\hline Válido & Direta Dura & 71 & 30,5 & 55,0 & 55,0 \\
& Direta Macia & 9 & 3,9 & 7,0 & 62,0 \\
& Não identificado & 43 & 18,5 & 33,3 & 95,3 \\
& Bipolar & 6 & 2,6 & 4,7 & 100,0 \\
Ausente & Total & 129 & 55,4 & 100,0 & \\
Total & 104 & 44,6 & & \\
\hline
\end{tabular}


Tabela 16 - Preparo de Talão

Preparo de Talão

\begin{tabular}{|ll|r|r|r|r|}
\hline & Frequência & Porcentual & $\begin{array}{c}\text { Porcentagem } \\
\text { válida }\end{array}$ & $\begin{array}{c}\text { Porcentagem } \\
\text { acumulativa }\end{array}$ \\
\hline Válido & Sim & 37 & 15,9 & 30,1 & 30,1 \\
& Não & 90 & 36,9 & 69,9 & 100,0 \\
& Total & 127 & 52,8 & 100,0 & \\
Ausente & Sistema & 110 & 47,2 & & \\
Total & & 233 & 100,0 & & \\
\hline
\end{tabular}

Tabela 17 - Classe de Talão

\section{Classe de Talão}

\begin{tabular}{|ll|r|r|r|r|}
\hline & Frequência & Porcentual & $\begin{array}{c}\text { Porcentagem } \\
\text { válida }\end{array}$ & $\begin{array}{c}\text { Porcentagem } \\
\text { acumulativa }\end{array}$ \\
\hline Válido & Cortical & 19 & 8,2 & 15,4 & 15,4 \\
& Liso & 60 & 23,2 & 43,9 & 59,3 \\
& Diedro & 4 & 1,7 & 3,3 & 62,6 \\
& Facetado & 2 &, 9 & 1,6 & 64,2 \\
& Linear & 20 & 8,6 & 16,3 & 80,5 \\
& Esmigalhado & 1 &, 4 &, 8 & 81,3 \\
& Puntiforme & 10 & 4,3 & 8,1 & 89,4 \\
& Retocado & 1 &, 4 &, 8 & 90,2 \\
Ausente & Sistema & 12 & 5,2 & 9,8 & 100,0 \\
Total & 129 & 52,8 & 100,0 & \\
\hline
\end{tabular}


Tabela 18 - Espessura de talão

Espessura do Talão

\begin{tabular}{|l|r|r|r|r|r|}
\hline & \multicolumn{1}{|c|}{$\mathrm{N}$} & \multicolumn{1}{|c|}{ Mínimo } & \multicolumn{1}{c|}{ Máximo } & \multicolumn{1}{c|}{ Média } & \multicolumn{1}{c|}{ Desvio Padrão } \\
\hline Espessura Talão & 127 & 1 & 12 & 3,09 & 2,497 \\
Válido $\mathrm{N}$ & 127 & & & & \\
\hline
\end{tabular}

Tabela 19 - Ângulo de talão com a face interna da lasca

Ângulo do Talão com a face interna da Lasca

\begin{tabular}{|ll|r|r|r|r|}
\hline & & Frequência & Porcentual & $\begin{array}{c}\text { Porcentagem } \\
\text { válida }\end{array}$ & $\begin{array}{c}\text { Porcentagem } \\
\text { acumulativa }\end{array}$ \\
\hline Válido & 70,0 & 1 &, 4 & 2,0 & 2,0 \\
& 80,0 & 1 &, 4 & 2,0 & 3,9 \\
& 90,0 & 32 & 12,5 & 62,7 & 66,7 \\
& 100,0 & 9 & 3,5 & 17,6 & 84,3 \\
& 110,0 & 2 &, 8 & 3,9 & 88,2 \\
& 120,0 & 4 & 1,6 & 7,8 & 96,1 \\
& 140,0 & 1 &, 4 & 2,0 & 98,0 \\
& 150,0 & 1 &, 4 & 2,0 & 100,0 \\
& Total & 51 & 20,0 & 100,0 & \\
Ausente & Sistema & 182 & 80,0 & & \\
Total & & 233 & 100,0 & & \\
\hline
\end{tabular}

Tabela 20 - Medidas das lascas e fragmentos de lascas

Medidas das lascas e fragmentos de lascas

\begin{tabular}{|l|r|r|r|r|r|}
\hline & N & Mínimo & Máximo & \multicolumn{1}{c|}{ Média } & \multicolumn{1}{c|}{$\begin{array}{c}\text { Desvio } \\
\text { padrão }\end{array}$} \\
\hline Comprimento & 172 & 2,0 & 70,0 & 16,837 & 7,6301 \\
Largura & 172 & 4,0 & 40,0 & 13,814 & 6,4446 \\
Espessura & 172 & 1,0 & 28,0 & 4,744 & 3,0596 \\
N válido (de lista) & 172 & & & & \\
\hline
\end{tabular}




\section{Conjunto 1- Arenito Silicificado.}

Tabela 21 - Suporte

Suporte

\begin{tabular}{|c|c|c|c|c|}
\hline & Frequência & Porcentual & $\begin{array}{l}\text { Porcentagem } \\
\text { válida }\end{array}$ & $\begin{array}{c}\text { Porcentagem } \\
\text { acumulativa }\end{array}$ \\
\hline Bloco & 53 & 100,0 & 100,0 & 100,0 \\
\hline
\end{tabular}

Tabela 22 - Córtex

Córtex

\begin{tabular}{|rl|r|r|r|r|}
\hline & Frequência & Porcentual & $\begin{array}{c}\text { Porcentagem } \\
\text { válida }\end{array}$ & $\begin{array}{c}\text { Porcentagem } \\
\text { acumulativa }\end{array}$ \\
\hline Válido & Não & 52 & 98,1 & 98,1 & 98,1 \\
& Sim & 1 & 1,9 & 1,9 & 100,0 \\
& Total & 53 & 100,0 & 100,0 & \\
\hline
\end{tabular}

\section{Tabela 23 - Classes}

Classes

\begin{tabular}{|ll|r|r|r|r|}
\hline & Frequência & Porcentual & $\begin{array}{c}\text { Porcentagem } \\
\text { válida }\end{array}$ & $\begin{array}{c}\text { Porcentagem } \\
\text { acumulativa }\end{array}$ \\
\hline Válido & Lasca & 27 & 50,9 & 50,9 & 50,9 \\
& Fragmento & 17 & 32,1 & 32,1 & 83,0 \\
& Frag Lasca & 9 & 17,0 & 17,0 & 100,0 \\
& Total & 53 & 100,0 & 100,0 & \\
\hline
\end{tabular}

\section{Tabela 24 - Classe de Lasca}

Classe de Lasca

\begin{tabular}{|ll|r|r|r|r|}
\hline & Frequência & Porcentual & $\begin{array}{c}\text { Porcentagem } \\
\text { válida }\end{array}$ & $\begin{array}{c}\text { Porcentagem } \\
\text { acumulativa }\end{array}$ \\
\hline Válido & Simples & 5 & 9,4 & 18,5 & 18,5 \\
& Siret & 4 & 7,5 & 14,8 & 33,3 \\
& Preparo de Núcle0 & 10 & 18,9 & 37,0 & 70,4 \\
& Descorticamento & 3 & 5,7 & 11,1 & 81,5 \\
& Bipolar & 5 & 9,4 & 18,5 & 100,0 \\
Ausente & Sistema & 27 & 50,9 & 100,0 & \\
Total & 26 & 49,1 & & \\
\hline
\end{tabular}


Tabela 25 - Percussão

Percussão

\begin{tabular}{|ll|r|r|r|r|}
\hline & Frequência & Porcentual & $\begin{array}{c}\text { Porcentagem } \\
\text { válida }\end{array}$ & $\begin{array}{c}\text { Porcentagem } \\
\text { acumulativa }\end{array}$ \\
\hline Válido & Direta Dura & 21 & 39,6 & 77,8 & 77,8 \\
& Não Identificada & 1 & 1,9 & 3,7 & 81,5 \\
& Bipolar & 5 & 9,4 & 18,5 & 100,0 \\
& Total & 27 & 50,9 & 100,0 & \\
Ausente & Sistema & 26 & 49,1 & & \\
Total & 53 & 100,0 & & \\
\hline
\end{tabular}

Tabela 26 - Preparo de Talão

\section{Preparo de Talão}

\begin{tabular}{|ll|r|r|r|r|}
\hline & Frequência & Porcentual & \multicolumn{2}{c|}{$\begin{array}{c}\text { Porcentagem } \\
\text { válida }\end{array}$} & $\begin{array}{c}\text { Porcentagem } \\
\text { acumulativa }\end{array}$ \\
\hline Válido & Sim & 2 & 3,8 & 7,4 & 7,4 \\
& Não & 20 & 37,7 & 74,1 & 81,5 \\
& Bipolar & 5 & 9,4 & 18,5 & 100,0 \\
Ausente & Sotal & 27 & 50,9 & 100,0 & \\
Total & 26 & 49,1 & & \\
\hline
\end{tabular}

Tabela 27 - Classe de Talão

Classe de Talão

\begin{tabular}{|ll|r|r|r|r|}
\hline & Frequência & Porcentual & $\begin{array}{c}\text { Porcentagem } \\
\text { válida }\end{array}$ & $\begin{array}{c}\text { Porcentagem } \\
\text { acumulativa }\end{array}$ \\
\hline Válido & Liso & 26 & 49,1 & 96,3 & 96,3 \\
& Puntiforme & 1 & 1,9 & 3,7 & 100,0 \\
& Total & 27 & 50,9 & 100,0 & \\
Ausente & Sistema & 26 & 49,1 & & \\
Total & & 53 & 100,0 & & \\
\hline
\end{tabular}


Tabela 28 Espessura do talão

Espessura do Talão

\begin{tabular}{|l|r|r|r|r|r|}
\hline & $N$ & Mínimo & Máximo & Média & $\begin{array}{c}\text { Desvio } \\
\text { Padrão }\end{array}$ \\
\hline $\begin{array}{l}\text { Espessura Talao } \\
\text { Válido } \mathrm{N}\end{array}$ & 26 & 3 & 30 & 12,44 & 6,002 \\
\hline
\end{tabular}

Tabela 29 - Ângulo do talão com a face interna da lasca

Ângulo do talão com a face interna da lasca

\begin{tabular}{|ll|r|r|r|r|}
\hline & Frequência & Porcentual & $\begin{array}{c}\text { Porcentagem } \\
\text { válida }\end{array}$ & $\begin{array}{c}\text { Porcentagem } \\
\text { acumulativa }\end{array}$ \\
\hline Válido & 80,0 & 1 & 1,9 & 4,8 & 4,8 \\
& 90,0 & 18 & 34,0 & 85,7 & 90,5 \\
& 100,0 & 2 & 3,8 & 9,5 & 100,0 \\
Ausente & Sistema & 21 & 39,6 & 100,0 & \\
Total & & 32 & 60,4 & & \\
\hline
\end{tabular}

Tabela 30 - Número de retiradas da face externa da lasca

Número de Retiradas da Face Externa das Lascas

\begin{tabular}{|ll|r|r|r|r|}
\hline & Frequência & Porcentual & $\begin{array}{c}\text { Porcentagem } \\
\text { válida }\end{array}$ & $\begin{array}{c}\text { Porcentagem } \\
\text { acumulativa }\end{array}$ \\
\hline Válido & 1,0 & 11 & 20,8 & 40,7 & 40,7 \\
& 2,0 & 9 & 17,0 & 33,3 & 74,1 \\
& 3,0 & 4 & 7,5 & 14,8 & 88,9 \\
& 4,0 & 2 & 3,8 & 7,4 & 96,3 \\
& 5,0 & 1 & 1,9 & 3,7 & 100,0 \\
Ausente & Sotal & 27 & 50,9 & 100,0 & \\
Total & Sistema & 26 & 49,1 & & \\
\hline
\end{tabular}


Tabela 31 - Medidas das lascas e fragmentos de lascas

Medidas de Lascas e Fragmentos de Lascas

\begin{tabular}{|l|r|r|r|r|r|}
\hline & N & Mínimo & Máximo & \multicolumn{1}{c|}{ Média } & \multicolumn{1}{c|}{$\begin{array}{c}\text { Desvio } \\
\text { padrão }\end{array}$} \\
\hline Comprimento & 36 & 16,0 & 110,0 & 44,750 & 24,3936 \\
Largura & 36 & 10,0 & 110,0 & 39,667 & 21,4063 \\
Espessura & 36 & 5,0 & 36,0 & 15,583 & 8,1499 \\
N válido (de lista) & 36 & & & & \\
\hline
\end{tabular}


Conjunto 2 de Arenito Silicificado -

Tabela 32 - Suporte

Suporte

\begin{tabular}{|rr|r|r|r|r|}
\hline & Frequência & Porcentual & $\begin{array}{c}\text { Porcentagem } \\
\text { válida }\end{array}$ & $\begin{array}{c}\text { Porcentagem } \\
\text { acumulativa }\end{array}$ \\
\hline Válido & Seixo & 3 & 2,9 & 2,9 & 2,9 \\
& Bloco & 99 & 97,1 & 97,1 & 100,0 \\
& Total & 102 & 100,0 & 100,0 & \\
\hline
\end{tabular}

Tabela 33 - Córtex

Córtex

\begin{tabular}{|rl|r|r|r|r|}
\hline & Frequência & Porcentual & $\begin{array}{c}\text { Porcentagem } \\
\text { válida }\end{array}$ & $\begin{array}{c}\text { Porcentagem } \\
\text { acumulativa }\end{array}$ \\
\hline Válido & Não & 64 & 62,7 & 62,7 & 62,7 \\
& Sim & 38 & 37,3 & 37,3 & 100,0 \\
& Total & 102 & 100,0 & 100,0 & \\
\hline
\end{tabular}

Tabela 34 - Classes

Classes

\begin{tabular}{|c|c|c|c|c|c|}
\hline & & Frequência & Porcentual & $\begin{array}{l}\text { Porcentagem } \\
\text { válida }\end{array}$ & $\begin{array}{c}\text { Porcentagem } \\
\text { acumulativa }\end{array}$ \\
\hline \multirow[t]{6}{*}{ Válido } & Lasca & 61 & 59,8 & 59,8 & 59,8 \\
\hline & Núcleo & 1 & 1,0 & 1,0 & 60,8 \\
\hline & Fragmento & 21 & 20,6 & 20,6 & 81,4 \\
\hline & Bloco lascado & 5 & 4,9 & 4,9 & 86,3 \\
\hline & Fragmento de Lasca & 14 & 13,7 & 13,7 & 100,0 \\
\hline & Total & 102 & 100,0 & 100,0 & \\
\hline
\end{tabular}


Tabela 35 - Classe de Lasca

Classe de Lasca

\begin{tabular}{|ll|r|r|r|r|}
\hline & Frequência & Porcentual & $\begin{array}{c}\text { Porcentagem } \\
\text { válida }\end{array}$ & $\begin{array}{c}\text { Porcentagem } \\
\text { acumulativa }\end{array}$ \\
\hline Válido & Simples & 13 & 13,7 & 22,6 & 22,6 \\
& Siret & 4 & 3,9 & 6,5 & 29,0 \\
& Inicial & 4 & 3,9 & 6,5 & 35,5 \\
& Flanco de Núcleo & 1 & 1,0 & 1,6 & 37,1 \\
& Preparo de Núcleo & 18 & 17,6 & 29,0 & 66,1 \\
& Descorticamento & 20 & 19,6 & 32,3 & 98,4 \\
& Bipolar & 1 & 1,0 & 1,6 & 100,0 \\
Ausente & Sotal & 61 & 60,8 & 100,0 & \\
Total & Sistema & 41 & 39,2 & & \\
\hline
\end{tabular}

Tabela 36 - Percussão

\section{Percussão}

\begin{tabular}{|ll|r|r|r|r|}
\hline & Frequência & Porcentual & $\begin{array}{c}\text { Porcentagem } \\
\text { válida }\end{array}$ & $\begin{array}{c}\text { Porcentagem } \\
\text { acumulativa }\end{array}$ \\
\hline Válido & Direta Dura & 45 & 44,1 & 73,8 & 73,8 \\
& Não Identificada & 15 & 14,7 & 24,6 & 98,4 \\
& Bipolar & 1 & 1,0 & 1,6 & 100,0 \\
& Total & 61 & 59,8 & 100,0 & \\
Ausente & Sistema & 41 & 40,2 & & \\
Total & 102 & 100,0 & & \\
\hline
\end{tabular}

Tabela 37 - Preparo de Talão

Preparo de Talão

\begin{tabular}{|ll|r|r|r|r|}
\hline & Frequência & Porcentual & $\begin{array}{c}\text { Porcentagem } \\
\text { válida }\end{array}$ & $\begin{array}{c}\text { Porcentagem } \\
\text { acumulativa }\end{array}$ \\
\hline Válido & Sim & 4 & 3,9 & 6,6 & 6,6 \\
& Não & 57 & 55,9 & 93,4 & 100,0 \\
& Total & 61 & 59,8 & 100,0 & \\
Ausente & Sistema & 41 & 40,2 & & \\
Total & & 102 & 100,0 & & \\
\hline
\end{tabular}


Tabela 38 - Classe de Talão

Classe de Talão

\begin{tabular}{|ll|r|r|r|r|}
\hline & Frequência & Porcentual & $\begin{array}{c}\text { Porcentagem } \\
\text { válida }\end{array}$ & $\begin{array}{c}\text { Porcentagem } \\
\text { acumulativa }\end{array}$ \\
\hline Válido & Cortical & 19 & 18,6 & 31,1 & 31,1 \\
& Liso & 41 & 40,2 & 67,2 & 98,4 \\
& Esmigalhado & 1 & 1,0 & 1,6 & 100,0 \\
& Total & 61 & 59,8 & 100,0 & \\
Ausente & Sistema & 41 & 40,2 & & \\
Total & 102 & 100,0 & & \\
\hline
\end{tabular}

Tabela 39 - Espessura do Talão

Espessura do Talão

\begin{tabular}{|l|r|r|r|r|r|}
\hline & N & Mínimo & Máximo & Média & $\begin{array}{c}\text { Desvio } \\
\text { padrão }\end{array}$ \\
\hline EspessuraTalao & 60 & 2,0 & 31,0 & 11,900 & 5,8706 \\
N válido (de lista) & 60 & & & & \\
\hline
\end{tabular}

Tabela 40 - Ângulo de talão com a face interna da lasca

Ängulo de talão com a face interna da Lasca

\begin{tabular}{|ll|r|r|r|r|}
\hline & & Frequência & Porcentual & $\begin{array}{c}\text { Porcentagem } \\
\text { válida }\end{array}$ & $\begin{array}{c}\text { Porcentagem } \\
\text { acumulativa }\end{array}$ \\
\hline Válido & 70,0 & 1 & 1,0 & 1,8 & 1,8 \\
& 80,0 & 5 & 4,9 & 8,8 & 10,5 \\
& 90,0 & 37 & 36,3 & 64,9 & 75,4 \\
& 95,0 & 1 & 1,0 & 1,8 & 77,2 \\
& 100,0 & 8 & 7,8 & 14,0 & 91,2 \\
& 110,0 & 4 & 3,9 & 7,0 & 98,2 \\
& 120,0 & 1 & 1,0 & 1,8 & 100,0 \\
Ausente & Sotal & 57 & 55,9 & 100,0 & \\
Total & Sistema & 45 & 44,1 & & \\
\hline
\end{tabular}


Tabela 41 - Número de retiradas da face externa da lasca

Número de Retiradas da Face Externa das Lascas

\begin{tabular}{|ll|r|r|r|r|}
\hline & Frequência & Porcentual & $\begin{array}{c}\text { Porcentagem } \\
\text { válida }\end{array}$ & $\begin{array}{c}\text { Porcentagem } \\
\text { acumulativa }\end{array}$ \\
\hline Válido & 1,0 & 28 & 27,5 & 45,9 & 45,9 \\
& 2,0 & 29 & 28,4 & 47,5 & 93,4 \\
& 3,0 & 2 & 2,0 & 3,3 & 96,7 \\
& 4,0 & 1 & 1,0 & 1,6 & 98,4 \\
& 5,0 & 1 & 1,0 & 1,6 & 100,0 \\
& Total & 61 & 59,8 & 100,0 & \\
Ausente & Sistema & 41 & 40,2 & & \\
Total & & 102 & 100,0 & & \\
\hline
\end{tabular}

Tabela 42 - Medidas das lascas e fragmentos das lascas

Medidas de Lasca e Fragmentos de Lasca

\begin{tabular}{|l|r|r|r|r|r|}
\hline & N & Mínimo & Máximo & Média & \multicolumn{1}{c|}{$\begin{array}{c}\text { Desvio } \\
\text { padrão }\end{array}$} \\
\hline Comprimento & 75 & 10,0 & 75,0 & 31,973 & 14,9666 \\
Largura & 75 & 7,0 & 110,0 & 31,653 & 16,8262 \\
Espessura & 75 & 2,0 & 28,0 & 12,520 & 5,7642 \\
N válido (de lista) & 75 & & & & \\
\hline
\end{tabular}




\section{Conjunto 3 de Arenito Silicificado -}

Tabela 43 - Suporte

Suporte

\begin{tabular}{|c|c|c|c|c|}
\hline & Frequência & Porcentual & $\begin{array}{l}\text { Porcentagem } \\
\text { válida }\end{array}$ & $\begin{array}{l}\text { Porcentagem } \\
\text { acumulativa }\end{array}$ \\
\hline Válido Seixo & 47 & 100,0 & 100,0 & 100,0 \\
\hline
\end{tabular}

Tabela 44 - Córtex

\section{Córtex}

\begin{tabular}{|rr|r|r|r|r|}
\hline & Frequência & Porcentual & $\begin{array}{c}\text { Porcentagem } \\
\text { válida }\end{array}$ & $\begin{array}{c}\text { Porcentagem } \\
\text { acumulativa }\end{array}$ \\
\hline Válido & Não & 22 & 46,8 & 46,8 & 46,8 \\
& Sim & 25 & 53,2 & 53,2 & 100,0 \\
& Total & 47 & 100,0 & 100,0 & \\
\hline
\end{tabular}

Tabela 45 - Classes

Classes

\begin{tabular}{|rl|r|r|r|r|}
\hline & Frequência & Porcentual & $\begin{array}{c}\text { Porcentagem } \\
\text { válida }\end{array}$ & $\begin{array}{c}\text { Porcentagem } \\
\text { acumulativa }\end{array}$ \\
\hline Válido & Lasca & 28 & 59,6 & 59,6 & 59,6 \\
& Fragmento & 11 & 23,4 & 23,4 & 83,0 \\
Frag Lasca & 7 & 14,9 & 14,9 & 97,9 \\
Frag Seixo & 1 & 2,1 & 2,1 & 100,0 \\
Total & 47 & 100,0 & 100,0 & \\
\hline
\end{tabular}


Tabela 46 - Classe de Lasca

Classe de Lasca

\begin{tabular}{|ll|r|r|r|r|}
\hline & Frequência & Porcentual & $\begin{array}{c}\text { Porcentagem } \\
\text { válida }\end{array}$ & $\begin{array}{c}\text { Porcentagem } \\
\text { acumulativa }\end{array}$ \\
\hline Válido & Simples & 2 & 4,3 & 7,1 & 7,1 \\
& Siret & 4 & 8,5 & 14,3 & 21,4 \\
& Inicial & 1 & 2,1 & 3,6 & 25,0 \\
& Preparo de Núcleo & 10 & 21,3 & 35,7 & 60,7 \\
& Descorticamento & 11 & 23,4 & 39,3 & 100,0 \\
& Total & 28 & 59,6 & 100,0 & \\
Ausente & Sistema & 19 & 40,4 & & \\
Total & & 47 & 100,0 & & \\
\hline
\end{tabular}

Tabela 47 - Percussão

Percussão

\begin{tabular}{|c|c|c|c|c|c|}
\hline & & Frequência & Porcentual & $\begin{array}{c}\text { Porcentagem } \\
\text { válida }\end{array}$ & $\begin{array}{c}\text { Porcentagem } \\
\text { acumulativa }\end{array}$ \\
\hline Válido & Direta Dura & 28 & 59,6 & \multirow[t]{3}{*}{100,0} & \multirow[t]{3}{*}{100,0} \\
\hline Ausente & Sistema & 19 & 40,4 & & \\
\hline Total & & 47 & 100,0 & & \\
\hline
\end{tabular}

Tabela 48 - Preparo de Talão

Preparo de Talão

\begin{tabular}{|ll|r|r|r|r|}
\hline & Frequência & Porcentual & $\begin{array}{c}\text { Porcentagem } \\
\text { válida }\end{array}$ & $\begin{array}{c}\text { Porcentagem } \\
\text { acumulativa }\end{array}$ \\
\hline Válido & Sim & 7 & 14,9 & 25,0 & 25,0 \\
& Não & 21 & 44,7 & 75,0 & 100,0 \\
& Total & 28 & 59,6 & 100,0 & \\
Ausente & Sistema & 19 & 40,4 & & \\
Total & & 47 & 100,0 & & \\
\hline
\end{tabular}


Tabela 49 - Classe de Talão

Classe de Talão

\begin{tabular}{|ll|r|r|r|r|}
\hline & Frequência & Porcentual & $\begin{array}{c}\text { Porcentagem } \\
\text { válida }\end{array}$ & $\begin{array}{c}\text { Porcentagem } \\
\text { acumulativa }\end{array}$ \\
\hline Válido & Cortical & 4 & 8,5 & 14,3 & 14,3 \\
& Liso & 19 & 40,4 & 67,9 & 82,1 \\
& Facetado & 1 & 2,1 & 3,6 & 85,7 \\
& Esmigalhado & 2 & 4,3 & 7,1 & 92,9 \\
& Puntiforme & 2 & 4,3 & 7,1 & 100,0 \\
& Total & 28 & 59,6 & 100,0 & \\
Ausente & Sistema & 19 & 40,4 & & \\
Total & & 47 & 100,0 & & \\
\hline
\end{tabular}

Tabela 50 - Espessura do Talão

Espessura do Talão

\begin{tabular}{|l|r|r|r|r|r|}
\hline & N & Mínimo & Máximo & Média & $\begin{array}{r}\text { Desvio } \\
\text { padrão }\end{array}$ \\
\hline EspessuraTalao & 24 & 2,0 & 25,0 & 10,429 & 6,3446 \\
N válido (de lista) & 24 & & & & \\
\hline
\end{tabular}

Tabela 51 - Ângulo do talão com a face interna da lasca

Ângulo de Talão da Face Interna da Lasca

\begin{tabular}{|c|c|c|c|c|c|}
\hline & & Frequência & Porcentual & $\begin{array}{c}\text { Porcentagem } \\
\text { válida }\end{array}$ & $\begin{array}{c}\text { Porcentagem } \\
\text { acumulativa }\end{array}$ \\
\hline \multirow[t]{5}{*}{ Válido } & 90,0 & 18 & 38,3 & 66,7 & 66,7 \\
\hline & 100,0 & 2 & 4,3 & 7,4 & 74,1 \\
\hline & 110,0 & 5 & 10,6 & 18,5 & 92,6 \\
\hline & 120,0 & 2 & 4,3 & 7,4 & 100,0 \\
\hline & Total & 27 & 57,4 & 100,0 & \\
\hline Ausente & Sistema & 20 & 42,6 & & \\
\hline Total & & 47 & 100,0 & & \\
\hline
\end{tabular}


Tabela 52 - Número de retirada da face externa da lasca

Número de Retiradas da Face Externa da Lasca

\begin{tabular}{|ll|r|r|r|r|}
\hline & Frequência & Porcentual & \multicolumn{1}{c|}{$\begin{array}{c}\text { Porcentagem } \\
\text { válida }\end{array}$} & $\begin{array}{c}\text { Porcentagem } \\
\text { acumulativa }\end{array}$ \\
\hline Válido & 1,0 & 14 & 29,8 & 50,0 & 50,0 \\
& 2,0 & 11 & 23,4 & 39,3 & 89,3 \\
& 3,0 & 2 & 4,3 & 7,1 & 96,4 \\
& 5,0 & 1 & 2,1 & 3,6 & 100,0 \\
& Total & 28 & 59,6 & 100,0 & \\
Ausente & Sistema & 19 & 40,4 & & \\
Total & & 47 & 100,0 & & \\
\hline
\end{tabular}

Tabela 53 - Medidas das lascas e fragmentos de lascas

Medidas de Lascas e Frag Lascas

\begin{tabular}{|l|r|r|r|r|r|}
\hline & N & Mínimo & Máximo & \multicolumn{1}{c|}{ Média } & \multicolumn{1}{c|}{$\begin{array}{c}\text { Desvio } \\
\text { padrão }\end{array}$} \\
\hline Comprimento & 35 & 15,0 & 96,0 & 37,171 & 16,9315 \\
Largura & 35 & 13,0 & 87,0 & 30,943 & 13,9325 \\
Espessura & 35 & 4,0 & 25,0 & 11,457 & 5,5272 \\
N válido (de lista) & 35 & & & & \\
\hline
\end{tabular}




\section{Conjunto 4 de Arenito Silicificado}

Tabela 54 - Suporte

Suporte

\begin{tabular}{|l|r|r|r|r|}
\hline & Frequencia & Percetual & $\begin{array}{c}\text { Percentual } \\
\text { Válido }\end{array}$ & $\begin{array}{c}\text { Percentual } \\
\text { Acumulativo }\end{array}$ \\
\hline Válido Bloco & 312 & 100,0 & 100,0 & 100,0 \\
\hline
\end{tabular}

Tabela 55 - Córtex

Córtex

\begin{tabular}{|rl|r|r|r|r|}
\hline & & & \multicolumn{1}{c|}{$\begin{array}{c}\text { Percentual } \\
\text { Válido }\end{array}$} & $\begin{array}{c}\text { Percentual } \\
\text { Acumulativo }\end{array}$ \\
\hline Válido & Sim & 3 & 1,0 & 1,0 & 100,0 \\
& Não & 309 & 99,0 & 99,0 & 99,0 \\
& Total & 312 & 100,0 & 100,0 & \\
\hline
\end{tabular}

Tabela 56 - Classes

Classes

\begin{tabular}{|ll|r|r|r|r|}
\hline & & & \multicolumn{1}{c|}{$\begin{array}{c}\text { Percentual } \\
\text { Válido }\end{array}$} & $\begin{array}{c}\text { Percentual } \\
\text { Acumulativo }\end{array}$ \\
\hline Válid & Lasca & 173 & 55,4 & 55,4 & 55,4 \\
0 & Fragmento & 76 & 24,4 & 24,4 & 79,8 \\
& Frag Lasca & 63 & 20,2 & 20,2 & 100,0 \\
& Total & 312 & 100,0 & 100,0 & \\
\hline
\end{tabular}


Tabela 57 - Classe de Lasca

Classe de Lasca

\begin{tabular}{|ll|r|r|r|r|}
\hline & Frequencia & Percentual & $\begin{array}{c}\text { Percentual } \\
\text { Válido }\end{array}$ & $\begin{array}{c}\text { Percentual } \\
\text { Acumulativo }\end{array}$ \\
\hline Válido & Simples & 51 & 16,3 & 29,5 & 29,5 \\
& Siret & 27 & 8,7 & 15,6 & 45,1 \\
& Flanco Núcleo & 4 & 1,3 & 2,3 & 47,4 \\
& Preparo Núcleo & 49 & 15,7 & 28,3 & 75,7 \\
& Descorticamento & 6 & 1,9 & 3,5 & 79,2 \\
& Acabamento & 35 & 11,2 & 20,2 & 99,4 \\
& Laminar & 1 &, 3 &, 6 & 100,0 \\
Ausência & Sotal & 173 & 55,4 & 100,0 & \\
Total & Sistema & 139 & 44,6 & & \\
\hline
\end{tabular}

Tabela 58 - Percussão

Percussão

\begin{tabular}{|c|c|c|c|c|c|}
\hline & & Percentual & Percentual & $\begin{array}{c}\text { Percentual } \\
\text { Válido }\end{array}$ & $\begin{array}{l}\text { Percentual } \\
\text { Acumulativo }\end{array}$ \\
\hline \multirow[t]{3}{*}{ Válido } & Dura Direta & 152 & 48,7 & 87,9 & 87,9 \\
\hline & Não Identificada & 21 & 6,7 & 12,1 & 100,0 \\
\hline & Total & 173 & 55,4 & 100,0 & \\
\hline Ausência & Sistema & 139 & 44,6 & & \\
\hline Total & & 312 & 100,0 & & \\
\hline
\end{tabular}

Tabela 59 - Preparo de Talão

Preparo de Talão

\begin{tabular}{|ll|r|r|r|r|}
\hline & Frequencia & Percentual & $\begin{array}{c}\text { Percentual } \\
\text { Válido }\end{array}$ & $\begin{array}{c}\text { Percentual } \\
\text { Acumulativo }\end{array}$ \\
\hline Válido & Sim & 41 & 13,1 & 23,7 & 23,7 \\
& Não & 132 & 42,3 & 76,3 & 100,0 \\
& Total & 173 & 55,4 & 100,0 & \\
Ausência & Sistema & 139 & 44,6 & & \\
Total & & 312 & 100,0 & & \\
\hline
\end{tabular}


Tabela 60 - Classe de Talão

Classe de Talão

\begin{tabular}{|ll|r|r|r|r|}
\hline & Frequencia & Percentual & $\begin{array}{c}\text { Percentual } \\
\text { Válido }\end{array}$ & $\begin{array}{c}\text { Percentual } \\
\text { Acumulativo }\end{array}$ \\
\hline Válido & Cortical & 3 & 1,0 & 1,7 & 1,7 \\
& Liso & 128 & 41,0 & 75,7 & 74,0 \\
& Diedro & 4 & 1,3 & 78,0 & 2,3 \\
& Facetado & 13 & 4,2 & 85,5 & 7,5 \\
& Linear & 12 & 3,8 & 92,5 & 6,9 \\
& Esmigalhado & 5 & 1,6 & 95,4 & 2,9 \\
& Puntiforme & 8 & 2,6 & 100,0 & 4,6 \\
Ausência & Sistema & 173 & 55,4 & & 100,0 \\
Total & 139 & 44,6 & & \\
\hline
\end{tabular}

Tabela 61 - Espessura do Talão

Espessura do Talão

\begin{tabular}{|l|r|r|r|r|r|}
\hline & \multicolumn{1}{|c|}{ N } & Mínimo & Máximo & Média & D. Padrão \\
\hline Espessura Talão & 160 & 1 & 27 & 7,68 & 5,704 \\
Valid N (listwise) & 160 & & & & \\
\hline
\end{tabular}

Tabela 62 - Ângulo do talão com a face interna da lasca

Ângulo do Talão com a Face Interna da Lasca

\begin{tabular}{|ll|r|r|r|r|}
\hline & & Frequencia & Percentual & $\begin{array}{c}\text { Percentual } \\
\text { Válido }\end{array}$ & $\begin{array}{c}\text { Percentual } \\
\text { Acumulativo }\end{array}$ \\
\hline Válido & 60 & 1 &, 3 &, 9 &, 9 \\
& 70 & 6 & 1,9 & 5,1 & 6,0 \\
& 80 & 21 & 6,7 & 17,9 & 23,9 \\
& 90 & 46 & 14,7 & 39,3 & 63,2 \\
& 100 & 21 & 6,7 & 17,9 & 81,2 \\
& 110 & 12 & 3,8 & 10,3 & 91,5 \\
& 120 & 9 & 2,9 & 7,7 & 99,1 \\
& 140 & 1 &, 3 &, 9 & 100,0 \\
Ausência & Sistema & 117 & 37,5 & 100,0 & \\
Total & 195 & 62,5 & & \\
\hline
\end{tabular}


Tabela 63 - Número de retiradas da face externa da lasca

Número de Retiradas da Face Externa da Lasca

\begin{tabular}{|ll|r|r|r|r|}
\hline & Frequencia & Percentual & $\begin{array}{c}\text { Percentual } \\
\text { Válido }\end{array}$ & $\begin{array}{c}\text { Percentual } \\
\text { Acumulativo }\end{array}$ \\
\hline Válido & 1 & 67 & 21,5 & 38,7 & 38,7 \\
& 2 & 60 & 19,2 & 34,7 & 73,4 \\
& 3 & 33 & 10,6 & 19,1 & 92,5 \\
& 4 & 8 & 2,6 & 4,6 & 97,1 \\
& 5 & 5 & 1,6 & 2,9 & 100,0 \\
& Total & 173 & 55,4 & 100,0 & \\
Ausência & Sistema & 139 & 44,6 & & \\
\hline
\end{tabular}

Tabela 64 - Medidas das lascas e fragmentos de lascas

Medidas das Lascas e Frag Lascas

\begin{tabular}{|l|r|r|r|r|r|}
\hline & \multicolumn{1}{|c|}{ N } & \multicolumn{1}{|c|}{ Mínimo } & Máximo & \multicolumn{1}{c|}{ Média } & \multicolumn{1}{c|}{ D.Padrão } \\
\hline Comprimento & 236 & 7 & 127 & 29,67 & 17,569 \\
Largura & 236 & 2 & 100 & 25,50 & 16,011 \\
Espessura & 236 & 2 & 50 & 9,61 & 7,154 \\
Válido N & 236 & & & & \\
(listwise) & & & & & \\
\hline
\end{tabular}




\section{Conjunto 5 de Arenito Silicificado}

Tabela 65 - Suporte

Suporte

\begin{tabular}{|ll|r|r|r|r|}
\hline & Frequência & Percentual & $\begin{array}{c}\text { Percentual } \\
\text { Válido }\end{array}$ & $\begin{array}{c}\text { Percentual } \\
\text { Acumulativo }\end{array}$ \\
\hline Válido & Bloco & 307 & 99,4 & 99,4 & 99,4 \\
& Não Identificado & 2 &, 6 &, 6 & 100,0 \\
& Total & 309 & 100,0 & 100,0 & \\
\hline
\end{tabular}

Tabela 66 - Córtex

Córtex

\begin{tabular}{|rl|r|r|r|r|}
\hline & Frequência & Percentual & \multicolumn{1}{c|}{$\begin{array}{c}\text { Percentual } \\
\text { Válido }\end{array}$} & $\begin{array}{c}\text { Percentual } \\
\text { Acumulativo }\end{array}$ \\
\hline Válido & Não & 307 & 99,4 & 99,4 & 99,4 \\
& Sim & 2 &, 6 &, 6 & 100,0 \\
& Total & 309 & 100,0 & 100,0 & \\
\hline
\end{tabular}

Tabela 67 - Classes

Classes

\begin{tabular}{|ll|r|r|r|r|}
\hline & Frequência & Percentual & $\begin{array}{c}\text { Percentual } \\
\text { Válido }\end{array}$ & $\begin{array}{c}\text { Percentual } \\
\text { Acumulativo }\end{array}$ \\
\hline Válido & Lasca & 163 & 52,8 & 52,8 & 52,8 \\
& Fragmento & 79 & 25,6 & 25,6 & 78,3 \\
& Fragmento de Lasca & 67 & 21,7 & 21,7 & 100,0 \\
& Total & 309 & 100,0 & 100,0 & \\
\hline
\end{tabular}


Tabela 68 - Classe de Lasca

Classe de Lasca

\begin{tabular}{|ll|r|r|r|r|}
\hline & Frequência & Percentual & $\begin{array}{c}\text { Percentual } \\
\text { Válido }\end{array}$ & $\begin{array}{c}\text { Percentual } \\
\text { Acumulativo }\end{array}$ \\
\hline Válido & Simples & 74 & 23,9 & 45,4 & 45,4 \\
& Com Dorso & 1 &, 3 &, 6 & 46,0 \\
& Siret & 14 & 4,5 & 8,6 & 54,6 \\
& Flanco de Núcleo & 3 & 1,0 & 1,8 & 56,4 \\
& Preparo de Núcleo & 51 & 16,5 & 31,3 & 87,7 \\
& Descorticamento & 5 & 1,6 & 3,1 & 90,8 \\
& Acabamento & 15 & 4,9 & 9,2 & 100,0 \\
Ausência & Sistema & 163 & 52,8 & 100,0 & \\
Total & 146 & 47,2 & & \\
\hline
\end{tabular}

Tabela 69 - Percussão

Percussão

\begin{tabular}{|c|c|c|c|c|c|}
\hline & & Frequência & Percentual & $\begin{array}{c}\text { Percentual } \\
\text { Válido }\end{array}$ & $\begin{array}{l}\text { Percentual } \\
\text { Acumulativo }\end{array}$ \\
\hline \multirow[t]{3}{*}{ Válido } & Direta Dura & 139 & 45,0 & 85,3 & 85,3 \\
\hline & Não Identificada & 24 & 7,8 & 14,7 & 100,0 \\
\hline & Total & 163 & 52,8 & 100,0 & \\
\hline Ausência & Sistema & 146 & 47,2 & & \\
\hline Total & & 309 & 100,0 & & \\
\hline
\end{tabular}

Tabela 70 - Preparo de Talão

Preparo de talão

\begin{tabular}{|ll|r|r|r|r|}
\hline & Frequência & Percentual & $\begin{array}{c}\text { Percentual } \\
\text { Válido }\end{array}$ & $\begin{array}{r}\text { Percentual } \\
\text { Acumulativo }\end{array}$ \\
\hline Válido & Sim & 24 & 7,8 & 14,7 & 14,7 \\
& Não & 139 & 45,0 & 85,3 & 100,0 \\
& Total & 163 & 52,8 & 100,0 & \\
\multicolumn{1}{|l|}{ Ausência Sistema } & 146 & 47,2 & & \\
\multicolumn{2}{|l|}{ Total } & 309 & 100,0 & & \\
\hline
\end{tabular}


Tabela 71 - Classe de Talão

Classe de Talão

\begin{tabular}{|c|c|c|c|c|}
\hline & Frequência & Percentual & $\begin{array}{c}\text { Percentual } \\
\text { Válido }\end{array}$ & $\begin{array}{l}\text { Percentual } \\
\text { Acumulativo }\end{array}$ \\
\hline Cortical & 2 & ,6 & 1,2 & 1,2 \\
\hline Liso & 139 & 45,0 & 85,3 & 86,5 \\
\hline Diedro & 1 &, 3 &, 6 & 87,1 \\
\hline Facetado & 8 & 2,6 & 4,9 & 92,0 \\
\hline Linear & 6 & 1,9 & 3,7 & 95,7 \\
\hline Esmigalhado & 1 & 3 &, 6 & 96,3 \\
\hline Puntiforme & 5 & 1,6 & 3,1 & 99,4 \\
\hline Outros & 1 & 3 &, 6 & 100,0 \\
\hline Total & 163 & 52,8 & 100,0 & \\
\hline Ausência Sistema & 146 & 47,2 & & \\
\hline Total & 309 & 100,0 & & \\
\hline
\end{tabular}

Tabela 72 - Espessura do Talão

Espessura do Talão

\begin{tabular}{|l|r|r|r|r|r|}
\hline & \multicolumn{1}{|c|}{ N } & \multicolumn{1}{c|}{ Minimo } & Máximo & Média & Desvio Padrã \\
\hline Espessura Talão & 158 & 1 & 27 & 8,01 & 4,610 \\
Válido N & 158 & & & & \\
\hline
\end{tabular}

Tabela 73 - Ângulo do talão com a face interna da lasca

Ângulo do Talão com a Face Interna da Lasca

\begin{tabular}{|ll|r|r|r|r|}
\hline & & Frequência & Percentual & $\begin{array}{l}\text { Percentual } \\
\text { Válido }\end{array}$ & $\begin{array}{l}\text { Percentual } \\
\text { Acumulativo }\end{array}$ \\
\hline Válido & 70 & 2 &, 6 & 1,6 & 1,6 \\
& 80 & 23 & 7,4 & 18,3 & 19,8 \\
& 90 & 43 & 13,9 & 34,1 & 54,0 \\
& 300 & 30 & 9,7 & 23,8 & 77,8 \\
& 110 & 27 & 8,7 & 21,4 & 99,2 \\
& 120 & 1 &, 3 &, 8 & 100,0 \\
& Total & 126 & 40,8 & 100,0 & \\
Ausência & Sistema & 183 & 59,2 & & \\
Total & 309 & 100,0 & & \\
\hline
\end{tabular}


Tabela 74 - Número de retiradas da face externa da lasca

Número de Retiradas da Face Externa da Lasca

\begin{tabular}{|rl|r|r|r|r|}
\hline & & Frequência & Percentual & $\begin{array}{c}\text { Percentual } \\
\text { Válido }\end{array}$ & $\begin{array}{l}\text { Percentual } \\
\text { Acumulativo }\end{array}$ \\
\hline Válido & 1 & 68 & 22,0 & 41,7 & 41,7 \\
& 2 & 53 & 17,2 & 32,5 & 74,2 \\
& 3 & 25 & 8,1 & 15,3 & 89,6 \\
& 4 & 15 & 4,9 & 9,2 & 98,8 \\
& 5 & 1 &, 3 &, 6 & 99,4 \\
& 6 & 1 &, 3 &, 6 & 100,0 \\
& Total & 163 & 52,8 & 100,0 & \\
Ausência & Sistema & 146 & 47,2 & & \\
Total & 309 & 100,0 & & \\
\hline
\end{tabular}

Tabela 75 - Medidas das lascas e fragmentos das lascas

Medidas das Lascas e Fragmentos de Lascas

\begin{tabular}{|l|r|r|r|r|r|}
\hline & \multicolumn{1}{|c|}{ N } & \multicolumn{1}{|c|}{ Minimo } & Máximo & \multicolumn{1}{c|}{ Média } & Desvio Padrão \\
\hline Comprimento & 230 & 7 & 94 & 28,59 & 15,505 \\
Largura & 230 & 2 & 80 & 25,95 & 15,277 \\
Espessura & 230 & 2 & 40 & 9,40 & 5,724 \\
Válidc W (listwise) & 229 & & & & \\
\hline
\end{tabular}




\section{Conjunto 6 de Arenito Silicificado}

Tabela 76 - Suporte

Suporte

\begin{tabular}{|c|c|c|c|c|c|}
\hline & & Frequência & Percentual & $\begin{array}{l}\text { Percentual } \\
\text { Válido }\end{array}$ & $\begin{array}{l}\text { Percentual } \\
\text { Acumulativo }\end{array}$ \\
\hline Válido & Bloco & 10 & 100,0 & 100,0 & 100,0 \\
\hline
\end{tabular}

Tabela 77 - Córtex

Córtex

\begin{tabular}{|l|r|r|r|r|}
\hline & Freauência & Percentual & $\begin{array}{c}\text { Percentual } \\
\text { Válido }\end{array}$ & $\begin{array}{c}\text { Percentual } \\
\text { Acumulativo }\end{array}$ \\
\hline Válido Não & 10 & 100,0 & 100,0 & 100,0 \\
\hline
\end{tabular}

Tabela 78 - Classes

Classes

\begin{tabular}{|ll|r|r|r|r|}
\hline & Frequência & Percentual & $\begin{array}{c}\text { Percentual } \\
\text { Válido }\end{array}$ & $\begin{array}{c}\text { Percentual } \\
\text { Acumulativo }\end{array}$ \\
\hline Válido & Lasca & 5 & 50,0 & 50,0 & 50,0 \\
& Fragmento & 1 & 10,0 & 10,0 & 60,0 \\
Fragmento de Lasca & 4 & 40,0 & 40,0 & 100,0 \\
Total & 10 & 100,0 & 100,0 & \\
\hline
\end{tabular}


Tabela 79 - Classe de Lasca

Classe de Lasca

\begin{tabular}{|ll|r|r|r|r|}
\hline & Frequência & Percentual & $\begin{array}{c}\text { Percentual } \\
\text { Válido }\end{array}$ & $\begin{array}{c}\text { Percentual } \\
\text { Acumulativo }\end{array}$ \\
\hline Válido & Simples & 2 & 20,0 & 40,0 & 40,0 \\
& Preparo de Núcleo & 1 & 10,0 & 20,0 & 60,0 \\
& Acabamento & 2 & 20,0 & 40,0 & 100,0 \\
& Total & 5 & 50,0 & 100,0 & \\
Ausência & Sistema & 5 & 50,0 & & \\
Total & & 10 & 100,0 & & \\
\hline
\end{tabular}

Tabela 80- Percussão

Percussão

\begin{tabular}{|c|c|c|c|c|c|}
\hline & & Frequência & Percentual & $\begin{array}{c}\text { Percentual } \\
\text { Válido }\end{array}$ & $\begin{array}{l}\text { Percentual } \\
\text { Acumulativo }\end{array}$ \\
\hline \multirow[t]{3}{*}{ Válido } & Direta Dura & 4 & 40,0 & 80,0 & 80,0 \\
\hline & Não Identificada & 1 & 10,0 & 20,0 & 100,0 \\
\hline & Total & 5 & 50,0 & 100,0 & \\
\hline Ausência & Sistema & 5 & 50,0 & & \\
\hline Total & & 10 & 100,0 & & \\
\hline
\end{tabular}

Tabela 81 - Preparo de Talão

Preparo de Talão

\begin{tabular}{|ll|r|r|r|r|}
\hline & Frequência & Percentual & $\begin{array}{c}\text { Percentual } \\
\text { Válido }\end{array}$ & $\begin{array}{c}\text { Percentual } \\
\text { Acumulativo }\end{array}$ \\
\hline Válido & Não & 5 & 50,0 & 100,0 & 100,0 \\
Ausência & Sistema & 5 & 50,0 & & \\
Total & & 10 & 100,0 & & \\
\hline
\end{tabular}


Tabela 82 - Classe de Talão

Classe de Talão

\begin{tabular}{|ll|r|r|r|r|}
\hline & & & \multicolumn{1}{c|}{$\begin{array}{c}\text { Percentual } \\
\text { Válido }\end{array}$} & $\begin{array}{c}\text { Percental } \\
\text { Acumulativo }\end{array}$ \\
\hline Valid & Liso & 4 & 40,0 & 80,0 & 80,0 \\
& Puntiforme & 1 & 10,0 & 20,0 & 100,0 \\
& Total & 5 & 50,0 & 100,0 & \\
Ausência & Sistema & 5 & 50,0 & & \\
Total & & 10 & 100,0 & & \\
\hline
\end{tabular}

Tabela 83 - Espessura do Talão

Espessura do Talăo

\begin{tabular}{|l|r|r|r|r|r|}
\hline & $N$ & Mínimo & Máximo & Média & \multicolumn{1}{c|}{$\begin{array}{c}\text { Desvio } \\
\text { Padrão }\end{array}$} \\
\hline $\begin{array}{l}\text { Espessura Talão } \\
\text { Válido N }\end{array}$ & 4 & 1 & 10 & 4,80 & 3,701 \\
\hline
\end{tabular}

Tabela 84 - Ângulo do talão com a face interna da lasca

Ângulo do Talão com a Face Interna da Lasca

\begin{tabular}{|ll|r|r|r|r|}
\hline & Frequência & Percentual & $\begin{array}{c}\text { Percentual } \\
\text { Válido }\end{array}$ & $\begin{array}{c}\text { Percentual } \\
\text { Acumulativo }\end{array}$ \\
\hline Válido & 80 & 4 & 40,0 & 80,0 & 80,0 \\
& 90 & 1 & 10,0 & 20,0 & 100,0 \\
& Total & 5 & 50,0 & 100,0 & \\
Ausência & Sistema & 5 & 50,0 & & \\
Total & & 10 & 100,0 & & \\
\hline
\end{tabular}


Tabela 85 - Número de retiradas da face externa da lasca

Número de Retiradas da Face Externa da Lasca

\begin{tabular}{|ll|r|r|r|r|}
\hline & Frequência & Percentual & $\begin{array}{c}\text { Percentual } \\
\text { Válido }\end{array}$ & $\begin{array}{c}\text { Percentual } \\
\text { Acumulativo }\end{array}$ \\
\hline Válido & 1 & 2 & 20,0 & 40,0 & 40,0 \\
& 2 & 2 & 20,0 & 40,0 & 80,0 \\
& 3 & 1 & 10,0 & 20,0 & 100,0 \\
& Total & 5 & 50,0 & 100,0 & \\
Ausência & Sistema & 5 & 50,0 & & \\
Total & 10 & 100,0 & & \\
\hline
\end{tabular}

Tabela 86 - Medidas das lascas e fragmentos das lascas

Medidas das Lascas e Fragmentos de Lascas

\begin{tabular}{|l|r|r|r|r|r|}
\hline & N & Mínimo & Máximo & Média & \multicolumn{1}{c|}{$\begin{array}{c}\text { Desvio } \\
\text { Padrão }\end{array}$} \\
\hline Comprimento & 9 & 11 & 57 & 28,78 & 18,185 \\
Largura & 9 & 10 & 98 & 29,56 & 26,595 \\
Espessura & 9 & 2 & 30 & 10,22 & 8,423 \\
Válido N (listwise) & 9 & & & & \\
\hline
\end{tabular}




\section{Conjunto 7 de Arenito Silicificado}

Tabela 87 - Suporte

Suporte

\begin{tabular}{|ll|r|r|r|r|}
\hline & Frequência & Percentual & \multicolumn{1}{c|}{$\begin{array}{c}\text { Percentual } \\
\text { Válido }\end{array}$} & $\begin{array}{c}\text { Percentual } \\
\text { Acumulativo }\end{array}$ \\
\hline Válido & Seixo & 4 & 4,0 & 4,0 & 4,0 \\
& Bloco & 96 & 95,0 & 95,0 & 99,0 \\
Não identificado & 1 & 1,0 & 1,0 & 100,0 \\
Total & 101 & 100,0 & 100,0 & \\
\hline
\end{tabular}

Tabela 88 - Córtex

Córtex

\begin{tabular}{|rl|r|r|r|r|}
\hline & Frequência & Percentual & \multicolumn{1}{c|}{$\begin{array}{c}\text { Percentual } \\
\text { Válido }\end{array}$} & $\begin{array}{c}\text { Percentual } \\
\text { Acumulativo }\end{array}$ \\
\hline Válido & Não & 91 & 90,1 & 90,1 & 90,1 \\
& Sim & 10 & 9,9 & 9,9 & 100,0 \\
& Total & 101 & 100,0 & 100,0 & \\
\hline
\end{tabular}

Tabela 89 - Classes

\section{Classes}

\begin{tabular}{|ll|r|r|r|r|}
\hline & Frequência & Percentual & $\begin{array}{c}\text { Percentual } \\
\text { Válido }\end{array}$ & $\begin{array}{c}\text { Percentual } \\
\text { Acumulativo }\end{array}$ \\
\hline Válido & Lasca & 63 & 62,4 & 62,4 & 62,4 \\
& Fragmento & 7 & 6,9 & 6,9 & 69,3 \\
Fragmento Térmico & 1 & 1,0 & 1,0 & 70,3 \\
Fragmento de Lasca & 30 & 29,7 & 29,7 & 100,0 \\
Total & 101 & 100,0 & 100,0 & \\
\hline
\end{tabular}


Tabela 90 - Classe de Lasca

Classe de Lasca

\begin{tabular}{|ll|r|r|r|r|}
\hline & & Frequência & Percentual & $\begin{array}{c}\text { Percentual } \\
\text { Válido }\end{array}$ & $\begin{array}{c}\text { Percentual } \\
\text { Acumulativo }\end{array}$ \\
\hline Válido & Simples & 16 & 15,8 & 25,4 & 25,4 \\
& Siret & 3 & 3,0 & 4,8 & 30,2 \\
& Preparo de Núcleo & 15 & 14,9 & 23,8 & 54,0 \\
& Descorticamento & 11 & 10,9 & 17,5 & 71,4 \\
& Acabamento & 15 & 14,9 & 23,8 & 95,2 \\
& Retoque & 3 & 3,0 & 4,8 & 100,0 \\
Ausência & Sistema & 63 & 62,4 & 100,0 & \\
Total & & 38 & 37,6 & & \\
\hline
\end{tabular}

Tabela 91 - Percussão

Percussão

\begin{tabular}{|ll|r|r|r|r|}
\hline & Frequência & Percentual & $\begin{array}{c}\text { Percentual } \\
\text { Válido }\end{array}$ & $\begin{array}{c}\text { Percentual } \\
\text { Acumulativo }\end{array}$ \\
\hline Válido & Direta Dura & 62 & 61,4 & 98,4 & 98,4 \\
& Não Identificado & 1 & 1,0 & 1,6 & 100,0 \\
& Total & 63 & 62,4 & 100,0 & \\
Ausência & Sistema & 38 & 37,6 & & \\
Total & & 101 & 100,0 & & \\
\hline
\end{tabular}

Tabela 92 - Preparo de talão

Preparo de Talăo

\begin{tabular}{|ll|r|r|r|r|}
\hline & Frequência & Percentual & $\begin{array}{c}\text { Percentual } \\
\text { Válido }\end{array}$ & $\begin{array}{c}\text { Percentual } \\
\text { Acumulativo }\end{array}$ \\
\hline Válido & Sim & 10 & 9,9 & 15,9 & 15,9 \\
& Não & 53 & 52,5 & 84,1 & 100,0 \\
Ausência & Sistema & 63 & 62,4 & 100,0 & \\
Total & 38 & 37,6 & & \\
\hline
\end{tabular}


Tabela 93 - Classe de Talão

Classe de Talão

\begin{tabular}{|ll|r|r|r|r|}
\hline & Frequência & Percentual & \multicolumn{1}{c|}{$\begin{array}{c}\text { Percentual } \\
\text { Válido }\end{array}$} & $\begin{array}{c}\text { Percentual } \\
\text { Acumulativo }\end{array}$ \\
\hline Válido & Cortical & 5 & 5,0 & 7,9 & 7,9 \\
& Liso & 36 & 35,6 & 57,1 & 65,1 \\
& Diedro & 5 & 5,0 & 7,9 & 73,0 \\
& Facetado & 7 & 6,9 & 11,1 & 84,1 \\
& Linear & 4 & 4,0 & 6,3 & 90,5 \\
& Esmigalhado & 3 & 3,0 & 4,8 & 95,2 \\
& Puntiforme & 2 & 2,0 & 3,2 & 98,4 \\
Ausênc & Sistema & 1 & 1,0 & 1,6 & 100,0 \\
ia & Totros & 38 & 37,6 & 100,0 & \\
Total & & 101 & 100,0 & & \\
\hline
\end{tabular}

Tabela 94 - Espessura do talão

Espessura do Talăo

\begin{tabular}{|l|r|r|r|r|r|}
\hline & $\mathrm{N}$ & Mínimo & Máximo & \multicolumn{1}{c|}{ Média } & \multicolumn{1}{c|}{$\begin{array}{c}\text { Desvio } \\
\text { Padrão }\end{array}$} \\
\hline $\begin{array}{l}\text { Espessura } \\
\text { Válido } \mathrm{N}\end{array}$ & 58 & 1 & 20 & 6,57 & 4,475 \\
\hline
\end{tabular}


Tabela 95 - Ângulo do talão com a face interna da lasca

Ângulo do talão com a Face Interna da Lasca

\begin{tabular}{|ll|r|r|r|r|}
\hline & Frequência & Percentual & $\begin{array}{c}\text { Percentual } \\
\text { Válido }\end{array}$ & $\begin{array}{c}\text { Percentual } \\
\text { Acumulativo }\end{array}$ \\
\hline Válido & 70 & 2 & 2,0 & 4,1 & 4,1 \\
& 80 & 13 & 12,9 & 26,5 & 30,6 \\
& 90 & 19 & 18,8 & 38,8 & 69,4 \\
& 100 & 9 & 8,9 & 18,4 & 87,8 \\
& 110 & 4 & 4,0 & 8,2 & 95,9 \\
& 120 & 2 & 2,0 & 4,1 & 100,0 \\
& Total & 49 & 48,5 & 100,0 & \\
Ausência & Sistema & 52 & 51,5 & & \\
Total & & 101 & 100,0 & & \\
\hline
\end{tabular}

Tabela 96 - Número de retirada da face externa da lasca

Número de Retiradas da Face Externa das Lascas

\begin{tabular}{|ll|r|r|r|r|}
\hline & Frequência & Percentual & $\begin{array}{c}\text { Percentual } \\
\text { Válido }\end{array}$ & $\begin{array}{c}\text { Percentual } \\
\text { Acumulativo }\end{array}$ \\
\hline Válido & 1 & 21 & 20,8 & 33,3 & 33,3 \\
& 2 & 25 & 24,8 & 39,7 & 73,0 \\
& 3 & 9 & 8,9 & 14,3 & 87,3 \\
& 4 & 6 & 5,9 & 9,5 & 96,8 \\
& 5 & 2 & 2,0 & 3,2 & 100,0 \\
& Total & 63 & 62,4 & 100,0 & \\
Ausência & Sistema & 38 & 37,6 & & \\
Total & & 101 & 100,0 & & \\
\hline
\end{tabular}

Tabela 97 - Medidas das lascas e fragmentos das lascas

Medidas de Lascas e Fragmentos de Lasca

\begin{tabular}{|l|r|r|r|r|r|}
\hline & N & \multicolumn{1}{|c|}{ Mínimo } & Máximo & \multicolumn{1}{c|}{ Média } & \multicolumn{1}{c|}{$\begin{array}{c}\text { Desvio } \\
\text { Padrão }\end{array}$} \\
\hline Comprimento & 93 & 2 & 83 & 21,65 & 12,657 \\
Largura & 93 & 4 & 73 & 19,49 & 12,847 \\
Espessura & 93 & 2 & 42 & 6,90 & 5,477 \\
Válido N (listwise) & 93 & & & & \\
\hline
\end{tabular}




\section{Conjunto 8 de Arenito Silicificado}

Tabela 98 - Suporte

Suporte

\begin{tabular}{|c|c|c|c|c|c|}
\hline & & Frequência & Percentual & $\begin{array}{c}\text { Percentual } \\
\text { Válido }\end{array}$ & $\begin{array}{l}\text { Percentual } \\
\text { Acumulativo }\end{array}$ \\
\hline Válido & Seixo & 312 & 100,0 & 100,0 & 100,0 \\
\hline
\end{tabular}

Tabela 99 - Córtex

Córtex

\begin{tabular}{|ll|r|r|r|r|}
\hline & Frequência & Percentual & $\begin{array}{c}\text { Percentual } \\
\text { Válido }\end{array}$ & $\begin{array}{c}\text { Percentual } \\
\text { Acumulativo }\end{array}$ \\
\hline Válid & Não & 303 & 97,1 & 97,1 & 97,1 \\
0 & Sim & 9 & 2,9 & 2,9 & 100,0 \\
& Total & 312 & 100,0 & 100,0 & \\
\hline
\end{tabular}

Tabela 100 - Classe

Classe

\begin{tabular}{|ll|r|r|r|r|}
\hline & & Frequência & Percent & $\begin{array}{c}\text { Percentual } \\
\text { Válido }\end{array}$ & $\begin{array}{c}\text { Percentual } \\
\text { Acumulativo }\end{array}$ \\
\hline Válido & Lasca & 214 & 68,6 & 68,6 & 68,6 \\
& Fragmento & 58 & 18,6 & 18,6 & 87,2 \\
& Fragmento de Lasca & 40 & 12,8 & 12,8 & 100,0 \\
& Total & 312 & 100,0 & 100,0 & \\
\hline
\end{tabular}


Tabela 101 - Classe de Lasca

Classe de Lasca

\begin{tabular}{|ll|r|r|r|r|}
\hline & Frequência & Percentual & $\begin{array}{c}\text { Percentual } \\
\text { Válido }\end{array}$ & $\begin{array}{c}\text { Percentual } \\
\text { Acumulativo }\end{array}$ \\
\hline Válido & Simples & 53 & 16,2 & 24,8 & 24,8 \\
& Siret & 9 & 2,7 & 4,2 & 29,0 \\
& Inicial & 1 &, 3 &, 5 & 29,4 \\
& Preparo de Núcleo & 57 & 17,4 & 26,6 & 56,1 \\
& Descorticamento & 9 & 2,7 & 4,2 & 60,3 \\
& Acabamento & 57 & 17,4 & 26,6 & 86,9 \\
& Retoque & 28 & 8,5 & 13,1 & 100,0 \\
& Total & 214 & 65,2 & 100,0 & \\
Ausência & Sistema & 114 & 34,8 & & \\
Total & 328 & 100,0 & & \\
\hline
\end{tabular}

Tabela 102 - Percussão

Percussão

\begin{tabular}{|ll|r|r|r|r|}
\hline & & & \multicolumn{1}{c|}{$\begin{array}{c}\text { Percentual } \\
\text { Válido }\end{array}$} & $\begin{array}{c}\text { Percentual } \\
\text { Acumulativo }\end{array}$ \\
\hline Válido & Direta Dura & 151 & 48,4 & 70,6 & 70,6 \\
& Não Identificado & 63 & 20,2 & 29,4 & 100,0 \\
& Total & 214 & 68,6 & 100,0 & \\
Ausência & Sistema & 98 & 31,4 & & \\
Total & & 312 & 100,0 & & \\
\hline
\end{tabular}

Tabela 103 - Preparo de Talão

Preparo de Talão

\begin{tabular}{|ll|r|r|r|r|}
\hline & Frequência & Percentual & $\begin{array}{c}\text { Percentual } \\
\text { Válido }\end{array}$ & $\begin{array}{c}\text { Percentual } \\
\text { Acumulativo }\end{array}$ \\
\hline Válido & Sim & 78 & 25,0 & 36,4 & 36,4 \\
& Não & 136 & 43,6 & 63,6 & 100,0 \\
& Total & 214 & 68,6 & 100,0 & \\
Ausência & Sistema & 98 & 31,4 & & \\
Total & & 312 & 100,0 & & \\
\hline
\end{tabular}


Tabela 104 - Classe de Talão

Classe de Talão

\begin{tabular}{|ll|r|r|r|r|}
\hline & Frequência & Percentual & $\begin{array}{c}\text { Percentua } \\
\text { Válido }\end{array}$ & $\begin{array}{c}\text { Percentual } \\
\text { Acumulativo }\end{array}$ \\
\hline Válido & Cortical & 12 & 3,8 & 5,6 & 5,6 \\
& Liso & 140 & 44,9 & 65,4 & 71,0 \\
& Diedro & 1 &, 3 &, 5 & 71,5 \\
& Facetado & 24 & 7,7 & 11,2 & 82,7 \\
& Linear & 21 & 6,7 & 9,8 & 92,5 \\
& Esmigalhado & 1 &, 3 &, 5 & 93,0 \\
& Puntiforme & 7 & 2,2 & 3,3 & 96,3 \\
Ausência & Sistema & 214 & 68,6 & 3,7 & 100,0 \\
Total & Outros & 98 & 31,4 & 100,0 & \\
\hline
\end{tabular}

Tabela 105 - Espessura de Talão

Espessura do Talão

\begin{tabular}{|l|r|r|r|r|r|}
\hline Espessura Talão & \multicolumn{1}{|c|}{ N } & \multicolumn{1}{|c|}{ Mínimo } & Maximum & Média & Desvio Padrão \\
\hline & 206 & 1 & 25 & 4,42 & 3,207 \\
Válido N & 206 & & & & \\
(listwise) & & & & & \\
\hline
\end{tabular}


Tabela 106 - Ângulo do talão com a face interna da lasca

Ângulo do talão com a Face Interna da Lasca

\begin{tabular}{|ll|r|r|r|r|}
\hline & Frequência & \multicolumn{1}{c|}{$\begin{array}{c}\text { Percentual } \\
\text { Válido }\end{array}$} & $\begin{array}{c}\text { Percentual } \\
\text { Válido }\end{array}$ & $\begin{array}{c}\text { Percentual } \\
\text { Acumulativo }\end{array}$ \\
\hline Válido & 70 & 12 & 3,8 & 8,9 & 8,9 \\
& 80 & 37 & 11,9 & 27,4 & 36,3 \\
& 90 & 49 & 15,7 & 36,3 & 72,6 \\
& 100 & 21 & 6,7 & 15,6 & 88,1 \\
& 110 & 13 & 4,2 & 9,6 & 97,8 \\
& 120 & 3 & 1,0 & 2,2 & 100,0 \\
& Total & 135 & 43,3 & 100,0 & \\
Ausência & Sistema & 177 & 56,7 & & \\
Total & 312 & 100,0 & & \\
\hline
\end{tabular}

Tabela 107 - Número de retiradas da face externa da lasca

Número de Retiradas da Face Externa da Lasca

\begin{tabular}{|ll|r|r|r|r|}
\hline & Frequência & Percentual & $\begin{array}{c}\text { Percentual } \\
\text { Válido }\end{array}$ & $\begin{array}{c}\text { Percentual } \\
\text { Acumulativo }\end{array}$ \\
\hline Válido & 1 & 63 & 20,2 & 29,4 & 29,4 \\
& 2 & 79 & 25,3 & 36,9 & 66,4 \\
& 3 & 43 & 13,8 & 20,1 & 86,4 \\
& 4 & 18 & 5,8 & 8,4 & 94,9 \\
& 5 & 10 & 3,2 & 4,7 & 99,5 \\
& 6 & 1 &, 3 &, 5 & 100,0 \\
& Total & 214 & 68,6 & 100,0 & \\
Ausência & Sistema & 98 & 31,4 & & \\
Total & & 312 & 100,0 & & \\
\hline
\end{tabular}

Tabela 108 - Medidas das lascas e fragmentos das lascas

Medidas das Lascas e Fragmentos de Lasca

\begin{tabular}{|l|r|r|r|r|r|}
\hline & \multicolumn{1}{|c|}{ N } & \multicolumn{1}{|c|}{ Mínimo } & Máximo & \multicolumn{1}{c|}{ Média } & \multicolumn{1}{c|}{ Desvio Padrão } \\
\hline Comprimento & 254 & 5 & 55 & 18,07 & 8,754 \\
Largura & 254 & 2 & 64 & 15,39 & 8,458 \\
Espessura & 254 & 2 & 90 & 6,41 & 10,212 \\
Válido N & 254 & & & & \\
(listwise) & & & & & \\
\hline
\end{tabular}




\section{Conjunto 9 de Arenito Silicificado}

Tabela 109 - Suporte

Suporte

\begin{tabular}{|l|r|r|r|r|}
\hline & Frequência & Percentual & $\begin{array}{c}\text { Percentual } \\
\text { Válido }\end{array}$ & $\begin{array}{c}\text { Percentual } \\
\text { Acumulativo }\end{array}$ \\
\hline Válido Seixo & 364 & 100,0 & 100,0 & 100,0 \\
\hline
\end{tabular}

Tabela 110 - Córtex

Córtex

\begin{tabular}{|rl|r|r|r|r|}
\hline & Frequência & Percentual & \multicolumn{1}{c|}{$\begin{array}{c}\text { Percentual } \\
\text { Válido }\end{array}$} & $\begin{array}{c}\text { Percentual } \\
\text { Acumulativo }\end{array}$ \\
\hline Válido & Não & 361 & 99,2 & 99,2 & 99,2 \\
& Sim & 3 &, 8 &, 8 & 100,0 \\
& Total & 364 & 100,0 & 100,0 & \\
\hline
\end{tabular}

Tabela 111 - Classes

Classes

\begin{tabular}{|ll|r|r|r|r|}
\hline & Freauência & Percentual & $\begin{array}{c}\text { Percentual } \\
\text { Válido }\end{array}$ & $\begin{array}{c}\text { Cumulative } \\
\text { Percent }\end{array}$ \\
\hline Válido & Lasca & 213 & 58,5 & 58,5 & 58,5 \\
& Fragmento de Núcleo & 1 &, 3 &, 3 & 58,8 \\
Fragmento & 70 & 19,2 & 19,2 & 78,0 \\
Fragmento de Lasca & 80 & 22,0 & 22,0 & 100,0 \\
Total & 364 & 100,0 & 100,0 & \\
\hline
\end{tabular}


Tabela 112 - Classe de Lasca

Classe de Lasca

\begin{tabular}{|ll|r|r|r|r|}
\hline & Frequência & Percentual & $\begin{array}{c}\text { Percentual } \\
\text { Válido }\end{array}$ & $\begin{array}{c}\text { Percentual } \\
\text { Acumulativo }\end{array}$ \\
\hline Válido & Simples & 67 & 18,4 & 31,5 & 31,5 \\
& Siret & 3 &, 8 & 1,4 & 32,9 \\
& Flanco de Núcleo & 6 & 1,6 & 2,8 & 35,7 \\
& Preparo de Núcleo & 50 & 13,7 & 23,5 & 59,2 \\
& Acabamento & 38 & 10,4 & 17,8 & 77,0 \\
& Retoque & 49 & 13,5 & 23,0 & 100,0 \\
Ausência & Sotal & 213 & 58,5 & 100,0 & \\
Total & Sistema & 151 & 41,5 & & \\
\hline
\end{tabular}

Tabela 113 - Percussão

\section{Percussão}

\begin{tabular}{|ll|r|r|r|r|}
\hline & Frequência & Percentual & $\begin{array}{c}\text { Percentual } \\
\text { Válido }\end{array}$ & \multicolumn{1}{c|}{$\begin{array}{c}\text { Percentual } \\
\text { Acumulativo }\end{array}$} \\
\hline Válido & Direta Dura & 184 & 50,5 & 86,4 & 86,4 \\
& Não Identificada & 29 & 8,0 & 13,6 & 100,0 \\
& Total & 213 & 58,5 & 100,0 & \\
Ausente & Sistema & 151 & 41,5 & & \\
Total & & 364 & 100,0 & & \\
\hline
\end{tabular}

Tabela 114 - Preparo de Talão

Preparo de Talão

\begin{tabular}{|ll|r|r|r|r|}
\hline & Frequência & Percentual & \multicolumn{1}{c|}{$\begin{array}{c}\text { Percentual } \\
\text { Válido }\end{array}$} & $\begin{array}{c}\text { Percentual } \\
\text { Acumulativo }\end{array}$ \\
\hline Válido & Sim & 42 & 11,5 & 19,7 & 19,7 \\
& Não & 171 & 47,0 & 80,3 & 100,0 \\
& Total & 213 & 58,5 & 100,0 & \\
Ausência & Sistema & 151 & 41,5 & & \\
Total & & 364 & 100,0 & & \\
\hline
\end{tabular}


Tabela 115 - Classe de Talão

Classe de Talão

\begin{tabular}{|ll|r|r|r|r|}
\hline & Frequência & Percentual & $\begin{array}{c}\text { Percentual } \\
\text { Válido }\end{array}$ & $\begin{array}{c}\text { Percentual } \\
\text { Acumulativo }\end{array}$ \\
\hline Válido & Cortical & 3 & 2,5 & 4,2 & 4,2 \\
& Liso & 140 & 36,8 & 62,9 & 67,1 \\
& Diedro & 3 &, 8 & 1,4 & 68,5 \\
& Facetado & 12 & 3,3 & 5,6 & 74,2 \\
& Linear & 36 & 9,9 & 16,9 & 91,1 \\
& Esmigalhado & 4 & 1,1 & 1,9 & 93,0 \\
& Puntiforme & 6 & 1,6 & 2,8 & 95,8 \\
& 9 & 9 & 2,5 & 4,2 & 100,0 \\
& Total & 213 & 58,5 & 100,0 & \\
Ausente & Sistema & 151 & 41,5 & & \\
Total & & 364 & 100,0 & & \\
\hline
\end{tabular}

Tabela 116 - Espessura do talão

Espessura do Talão

\begin{tabular}{|l|l|r|r|r|r|}
\hline Espessura Talão & \multicolumn{1}{|c|}{ N } & \multicolumn{1}{|c|}{ Mínimo } & Máximo & \multicolumn{1}{c|}{ Média } & Desvio Padrão \\
\hline & 203 & 1 & 25 & 4,81 & 3,562 \\
Válido N \\
(listwise)
\end{tabular}

Tabela 117 - Ângulo de talão com a face interna da lasca

Ângulo do Talão com a Face Interna da Lasca

\begin{tabular}{|c|c|c|c|c|}
\hline & Frequência & Percentual & $\begin{array}{c}\text { Percentual } \\
\text { Válido }\end{array}$ & $\begin{array}{l}\text { Percentual } \\
\text { Acumulativo }\end{array}$ \\
\hline Válido & 282 & 77,5 & 77,5 & 77,5 \\
\hline 100 & 24 & 6,6 & 6,6 & 84,1 \\
\hline 110 & 6 & 1,6 & 1,6 & 85,7 \\
\hline 120 & 4 & 1,1 & 1,1 & 86,8 \\
\hline 80 & 14 & 3,8 & 3,8 & 90,7 \\
\hline 90 & 34 & 9,3 & 9,3 & 100,0 \\
\hline Total & 82 & 100,0 & 100,0 & \\
\hline
\end{tabular}


Tabela 118 - Número de retiradas da face externa da lasca

Número de Retiradas da Face Externa da Lasca

\begin{tabular}{|ll|r|r|r|r|}
\hline & Frequência & $\begin{array}{c}\text { Percent } \\
\text { ual }\end{array}$ & $\begin{array}{c}\text { Percentual } \\
\text { Válido }\end{array}$ & $\begin{array}{c}\text { Percentual } \\
\text { Acumulativo }\end{array}$ \\
\hline Válido & 1 & 89 & 24,5 & 41,8 & 41,8 \\
& 2 & 94 & 25,8 & 44,1 & 85,9 \\
& 3 & 19 & 5,2 & 8,9 & 94,8 \\
& 4 & 9 & 2,5 & 4,2 & 99,1 \\
& 5 & 2 &, 5 &, 9 & 100,0 \\
& Total & 213 & 58,5 & 100,0 & \\
Ausência & Sistema & 151 & 41,5 & & \\
Total & & 364 & 100,0 & & \\
\hline
\end{tabular}

Tabela 119 - Medidas das lascas e fragmentos das lascas

Medidas das Lascas e Fragmentos de Lasca

\begin{tabular}{|l|r|r|r|r|r|}
\hline & \multicolumn{1}{|c|}{ N } & \multicolumn{1}{|c|}{ Mínimo } & Máximo & \multicolumn{1}{c|}{ Média } & \multicolumn{1}{c|}{ Desvio Padrão } \\
\hline Comprimento & 293 & 4 & 117 & 16,69 & 10,830 \\
Largura & 293 & 4 & 64 & 14,68 & 8,497 \\
Espessura & 293 & 1 & 38 & 5,16 & 3,760 \\
Válido N (listwise) & 291 & & & & \\
\hline
\end{tabular}




\section{Conjunto 10 de Arenito Silicificado}

Tabela 120 - Suporte

Suporte

\begin{tabular}{|l|r|r|r|r|}
\hline & Frequência & Percentual & $\begin{array}{c}\text { Percentual } \\
\text { Válido }\end{array}$ & $\begin{array}{c}\text { Percentual } \\
\text { Acumulativo }\end{array}$ \\
\hline Válido Seixo & 192 & 100,0 & 100,0 & 100,0 \\
\hline
\end{tabular}

Tabela 121 - Córtex

Córtex

\begin{tabular}{|l|r|r|r|r|}
\hline & Frequência & Percentual & $\begin{array}{c}\text { Percentual } \\
\text { Válido }\end{array}$ & $\begin{array}{c}\text { Percentual } \\
\text { Acumulativo }\end{array}$ \\
\hline $\begin{array}{l}\text { Válid não } \\
0\end{array}$ & 192 & 100,0 & 100,0 & 100,0 \\
\hline
\end{tabular}

Tabela 122 - Classe

Classe

\begin{tabular}{|ll|r|r|r|r|}
\hline & Frequência & Percentual & $\begin{array}{c}\text { Percentual } \\
\text { Válido }\end{array}$ & $\begin{array}{c}\text { Percentual } \\
\text { Acumulativo }\end{array}$ \\
\hline Válido & Lasca & 111 & 57,8 & 57,8 & 57,8 \\
& Fragmento & 40 & 20,8 & 20,8 & 78,6 \\
& Fragmento de Lasca & 41 & 21,4 & 21,4 & 100,0 \\
& 192 & 100,0 & 100,0 & \\
\hline
\end{tabular}


Tabela 123 - Classe de Lasca

Classe de Lasca

\begin{tabular}{|ll|r|r|r|r|}
\hline & Frequência & Percentual & $\begin{array}{c}\text { Percentual } \\
\text { Válido }\end{array}$ & $\begin{array}{c}\text { Percentual } \\
\text { Acumulativo }\end{array}$ \\
\hline Válido & Simples & 41 & 21,4 & 36,9 & 36,9 \\
& Com Dorso & 1 &, 5 &, 9 & 37,8 \\
& Siret & 6 & 3,1 & 5,4 & 43,2 \\
& Preparo de & 16 & 8,3 & 14,4 & 57,7 \\
& Núcleo & & & \\
& Acabamento & 34 & 17,7 & 30,6 & 100,0 \\
& Retoque & 13 & 6,8 & 11,7 & \\
Ausente & Sotal & 111 & 57,8 & 100,0 & \\
Total & Sistema & 81 & 42,2 & & \\
\hline
\end{tabular}

Tabela 124 - Percussão

Percussão

\begin{tabular}{|ll|r|r|r|r|}
\hline & Frequência & $\begin{array}{c}\text { Percent } \\
\text { ual }\end{array}$ & $\begin{array}{c}\text { Percentual } \\
\text { Válido }\end{array}$ & $\begin{array}{c}\text { Percentual } \\
\text { Acumulativo }\end{array}$ \\
\hline Válido & Dura Direta & 88 & 45,8 & 79,3 & 79,3 \\
& Não Identificada & 23 & 12,0 & 20,7 & 100,0 \\
Ausente & Total & 111 & 57,8 & 100,0 & \\
Total & & 81 & 42,2 & & \\
\hline
\end{tabular}

Tabela 125 - Preparo de Talão

Preparo de Talão

\begin{tabular}{|ll|r|r|r|r|}
\hline & Frequência & Percentual & $\begin{array}{c}\text { Percentual } \\
\text { Válido }\end{array}$ & $\begin{array}{c}\text { Percentual } \\
\text { Acumulativo }\end{array}$ \\
\hline Válido & Sim & 45 & 23,4 & 40,5 & 40,5 \\
& Não & 66 & 34,4 & 59,5 & 100,0 \\
& Total & 111 & 57,8 & 100,0 & \\
Ausente & Sistema & 81 & 42,2 & & \\
Total & & 192 & 100,0 & & \\
\hline
\end{tabular}


Tabela 126 - Classe de Talão

Classe de Talão

\begin{tabular}{|ll|r|r|r|r|}
\hline & Frequência & Percentual & $\begin{array}{c}\text { Percentual } \\
\text { Válido }\end{array}$ & $\begin{array}{c}\text { Percentual } \\
\text { Acumulativo }\end{array}$ \\
\hline Válido & Cortical & 4 & 2,1 & 3,6 & 3,6 \\
& Liso & 79 & 41,1 & 71,2 & 74,8 \\
& Facetado & 9 & 4,7 & 8,1 & 82,9 \\
& Linear & 13 & 6,8 & 11,7 & 94,6 \\
& Esmigalhad & 3 & 1,6 & 2,7 & 97,3 \\
& 0 & & & 1,8 & \\
& Puntiforme & 2 & 1,0 &, 9 & 98,2 \\
Ausent & Outros & 1 &, 5 & 100,0 & \\
Total & Sotal & 111 & 57,8 & & \\
Total & & 192 & 42,2 & & \\
\hline
\end{tabular}

Tabela 127 - Espessura de Talão

Espessura do Talão

\begin{tabular}{|l|r|r|r|r|r|}
\hline & N & Mínimo & Máximo & Média & $\begin{array}{r}\text { Desvio } \\
\text { Padrão }\end{array}$ \\
\hline & 106 & 1 & 17 & 4,29 & 3,046 \\
Válido $N$ & 106 & & & & \\
\hline
\end{tabular}


Tabela 128 - Ângulo de talão com a face interna da lasca

Ângulo do Talão com a Face Interna da Lasca

\begin{tabular}{|ll|r|r|r|r|}
\hline & & Frequência & Percentual & $\begin{array}{c}\text { Percentual } \\
\text { Válido }\end{array}$ & $\begin{array}{c}\text { Percentual } \\
\text { Acumulativo }\end{array}$ \\
\hline Válido & 80 & 12 & 6,3 & 17,6 & 17,6 \\
& 90 & 35 & 18,2 & 51,5 & 69,1 \\
& 100 & 12 & 6,3 & 17,6 & 86,8 \\
& 110 & 8 & 4,2 & 11,8 & 98,5 \\
& 120 & 1 &, 5 & 1,5 & 100,0 \\
& Total & 68 & 35,4 & 100,0 & \\
Ausente & Sistema & 124 & 64,6 & & \\
Total & & 192 & 100,0 & & \\
\hline
\end{tabular}

Tabela 129 - Número de retiradas da face externa da lasca

Número de Retiradas da Face Externa da Lasca

\begin{tabular}{|ll|r|r|r|r|}
\hline & Frequência & Percentual & $\begin{array}{c}\text { Percentual } \\
\text { Válido }\end{array}$ & $\begin{array}{c}\text { Percentual } \\
\text { Acumulativo }\end{array}$ \\
\hline Válido & 1 & 46 & 24,0 & 41,4 & 41,4 \\
& 2 & 35 & 18,2 & 31,5 & 73,0 \\
& 3 & 25 & 13,0 & 22,5 & 95,5 \\
& 4 & 4 & 2,1 & 3,6 & 99,1 \\
& 5 & 1 &, 5 &, 9 & 100,0 \\
& Total & 111 & 57,8 & 100,0 & \\
Ausente & Sistema & 81 & 42,2 & & \\
Total & & 192 & 100,0 & & \\
\hline
\end{tabular}

Tabela 130 - Medidas das lascas e fragmentos das lascas

Medidas das Lascas e Fragmentos das Lascas

\begin{tabular}{|l|r|r|r|r|r|}
\hline & \multicolumn{1}{|c|}{ N } & \multicolumn{1}{|c|}{ Mínimo } & Máximo & \multicolumn{1}{c|}{ Média } & \multicolumn{1}{c|}{$\begin{array}{c}\text { Desvio } \\
\text { Padrão }\end{array}$} \\
\hline Comprimento & 152 & 5 & 45 & 19,15 & 7,463 \\
Largura & 152 & 5 & 48 & 15,33 & 6,609 \\
Espessura & 152 & 2 & 70 & 5,52 & 5,999 \\
Válido N (listwise) & 152 & & & & \\
\hline
\end{tabular}




\section{Conjunto 11 de Arenito Silicificado}

Tabela 131 - Suporte

Suporte

\begin{tabular}{|c|c|c|c|c|c|}
\hline & & Frequência & Percentual & $\begin{array}{c}\text { Percentual } \\
\text { Válido }\end{array}$ & $\begin{array}{l}\text { Percentual } \\
\text { Acumulativo }\end{array}$ \\
\hline Válido & Seixo & 160 & 100,0 & 100,0 & 100,0 \\
\hline
\end{tabular}

Tabela 132 - Córtex

Córtex

\begin{tabular}{|rc|r|r|r|r|}
\hline & Freauência & Percentual & $\begin{array}{c}\text { Percentual } \\
\text { Válido }\end{array}$ & $\begin{array}{c}\text { Percentual } \\
\text { Acumulativo }\end{array}$ \\
\hline Não & Não & 151 & 94,4 & 94,4 & 94,4 \\
& Sim & 9 & 5,6 & 5,6 & 100,0 \\
& Total & 160 & 100,0 & 100,0 & \\
\hline
\end{tabular}

Tabela 133 - Classes

Classe

\begin{tabular}{|c|c|c|c|c|c|}
\hline & & Frequência & $\begin{array}{c}\text { Percentual } \\
\text { Válido }\end{array}$ & $\begin{array}{c}\text { Percentual } \\
\text { Válido }\end{array}$ & $\begin{array}{l}\text { Percentual } \\
\text { Acumulativo }\end{array}$ \\
\hline \multirow[t]{5}{*}{ Válido } & Lasca & 93 & 58,1 & 58,1 & 58,1 \\
\hline & Fragmento & 24 & 15,0 & 15,0 & 73,1 \\
\hline & Seixo Lascado & 1 &, 6 & 6 & 73,8 \\
\hline & Fragmento de Lasca & 42 & 26,3 & 26,3 & 100,0 \\
\hline & Total & 160 & 100,0 & 100,0 & \\
\hline
\end{tabular}


Tabela 134 - Classe de Lasca

Classe de Lasca

\begin{tabular}{|ll|r|r|r|r|}
\hline & Frequência & Percentual & $\begin{array}{c}\text { Percentual } \\
\text { Válido }\end{array}$ & $\begin{array}{c}\text { Percentual } \\
\text { Acumulativo }\end{array}$ \\
\hline Válido & Simples & 25 & 15,6 & 26,9 & 26,9 \\
& Siret & 6 & 3,8 & 6,5 & 33,3 \\
& Preparo de Núcleo & 30 & 18,8 & 32,3 & 65,6 \\
& Descorticamento & 7 & 4,4 & 7,5 & 73,1 \\
& Acabamento & 22 & 13,8 & 23,7 & 96,8 \\
& Retoque & 3 & 1,9 & 3,2 & 100,0 \\
& Total & 93 & 58,1 & 100,0 & \\
Ausente & Sistema & 67 & 41,9 & & \\
Total & & 160 & 100,0 & & \\
\hline
\end{tabular}

Tabela 135 - Percussão

\section{Percussão}

\begin{tabular}{|ll|r|r|r|r|}
\hline & Frequência & Percentual & $\begin{array}{c}\text { Percentual } \\
\text { Válido }\end{array}$ & $\begin{array}{c}\text { Percentual } \\
\text { Acumulativo }\end{array}$ \\
\hline Válido & Dura Direta & 82 & 51,2 & 88,2 & 88,2 \\
& Não Identificada & 11 & 6,9 & 11,8 & 100,0 \\
& Total & 93 & 58,1 & 100,0 & \\
Ausente & Sistema & 67 & 41,9 & & \\
Total & & 160 & 100,0 & & \\
\hline
\end{tabular}

Tabela 136 - Preparo de Talão

Preparo de Talão

\begin{tabular}{|ll|r|r|r|r|}
\hline & Frequência & Percentual & \multicolumn{1}{c|}{$\begin{array}{c}\text { Percentual } \\
\text { Válido }\end{array}$} & $\begin{array}{c}\text { Percentual } \\
\text { Acumulativo }\end{array}$ \\
\hline Válido & Sim & 36 & 22,5 & 38,7 & 38,7 \\
& Não & 57 & 35,6 & 61,3 & 100,0 \\
& Total & 93 & 58,1 & 100,0 & \\
Ausente & Sistema & 67 & 41,9 & & \\
Total & & 160 & 100,0 & & \\
\hline
\end{tabular}


Tabela 137 - Classe de Talão

Classe de Talão

\begin{tabular}{|ll|r|r|r|r|}
\hline & Frequência & Percentual & \multicolumn{1}{|c|}{$\begin{array}{c}\text { Percentual } \\
\text { Válido }\end{array}$} & $\begin{array}{c}\text { Percentual } \\
\text { Acumulativo }\end{array}$ \\
\hline Válido & Cortical & 6 & 3,8 & 6,5 & 6,5 \\
& Liso & 62 & 38,8 & 66,7 & 73,1 \\
& Diedro & 3 & 1,9 & 3,2 & 76,3 \\
& Facetado & 7 & 4,4 & 7,5 & 83,9 \\
& Linear & 8 & 5,0 & 8,6 & 92,5 \\
& Puntiforme & 1 &, 6 & 1,1 & 93,5 \\
& Outros & 6 & 3,8 & 6,5 & 100,0 \\
Ausente & Sistema & 93 & 58,1 & 100,0 & \\
Total & 67 & 41,9 & & \\
\hline
\end{tabular}

Tabela 138 - Espessura do talão

Espessura do Talão

\begin{tabular}{|l|r|r|r|r|r|}
\hline & $\mathrm{N}$ & Mínimo & Máximo & Média & $\begin{array}{c}\text { Desvio } \\
\text { Padrão }\end{array}$ \\
\hline Espessura Talao & 92 & 1 & 25 & 5,16 & 3,675 \\
Válido $\mathrm{N}$ & 92 & & & & \\
\hline
\end{tabular}

Tabela 139 - Ângulo do talão com a face interna da lasca

Ângulo do talão com a Face Interna da Lasca

\begin{tabular}{|ll|r|r|r|r|}
\hline & Frequência & Percentual & \multicolumn{1}{c|}{$\begin{array}{c}\text { Percentual } \\
\text { Válido }\end{array}$} & $\begin{array}{c}\text { Percentual } \\
\text { Acumulativo }\end{array}$ \\
\hline Válido & 70 & 2 & 1,3 & 3,4 & 3,4 \\
& 80 & 12 & 7,5 & 20,3 & 23,7 \\
& 90 & 18 & 11,3 & 30,5 & 54,2 \\
& 100 & 15 & 9,4 & 25,4 & 79,7 \\
& 110 & 8 & 5,0 & 13,6 & 93,2 \\
& 120 & 4 & 2,5 & 6,8 & 100,0 \\
Ausente & Sistema & 101 & 63,1 & 100,0 & \\
Total & & 160 & 100,0 & & \\
\hline
\end{tabular}


Tabela 140 - Número de retiradas da face externa das lascas

Número de Retiradas da Face Externa da Lasca

\begin{tabular}{|ll|r|r|r|r|}
\hline & Frequência & Percentual & $\begin{array}{c}\text { Percentual } \\
\text { Válido }\end{array}$ & $\begin{array}{c}\text { Percentual } \\
\text { Acumulativo }\end{array}$ \\
\hline Válido & 1 & 33 & 20,6 & 35,5 & 35,5 \\
& 2 & 26 & 16,3 & 28,0 & 63,4 \\
& 3 & 19 & 11,9 & 20,4 & 83,9 \\
& 4 & 11 & 6,9 & 11,8 & 95,7 \\
& 5 & 3 & 1,9 & 3,2 & 98,9 \\
& 6 & 1 &, 6 & 1,1 & 100,0 \\
Ausente & Sistema & 93 & 58,1 & 100,0 & \\
Total & & 67 & 41,9 & & \\
\hline
\end{tabular}

Tabela 141 - Medidas das lascas e fragmentos das lascas

Medidas das Lascas e Fragmentos das Lascas

\begin{tabular}{|l|r|r|r|r|r|}
\hline & N & Mínimo & Máximo & \multicolumn{1}{c|}{ Média } & \multicolumn{1}{c|}{$\begin{array}{c}\text { Desvio } \\
\text { Padrão }\end{array}$} \\
\hline Comprimento & 135 & 7 & 120 & 21,93 & 12,511 \\
Largura & 135 & 4 & 50 & 18,50 & 8,516 \\
Espessura & 135 & 1 & 25 & 6,05 & 3,478 \\
Valid N (listwise) & 135 & & & & \\
\hline
\end{tabular}




\section{Conjunto 12 de Arenito Silicificado}

Tabela 142 - Suporte

Suporte

\begin{tabular}{|l|r|r|r|r|}
\hline & Frequência & Percentua & $\begin{array}{c}\text { Percentual } \\
\text { Válido }\end{array}$ & $\begin{array}{c}\text { Percentual } \\
\text { Acumulativo }\end{array}$ \\
\hline Válido Seixo & 202 & 100,0 & 100,0 & 100,0 \\
\hline
\end{tabular}

Tabela 143 - Córtex

Córtex

\begin{tabular}{|ll|r|r|r|r|}
\hline & Frequência & Percentual & \multicolumn{1}{c|}{$\begin{array}{c}\text { Percentual } \\
\text { Válido }\end{array}$} & $\begin{array}{c}\text { Percentual } \\
\text { Acumulativo }\end{array}$ \\
\hline Válid & Não & 129 & 63,9 & 63,9 & 63,9 \\
0 & Sim & 73 & 36,1 & 36,1 & 100,0 \\
& Total & 202 & 100,0 & 100,0 & \\
\hline
\end{tabular}

Tabela 144 - Classes

\section{Classes}

\begin{tabular}{|ll|r|r|r|r|}
\hline & & & \multicolumn{1}{|c|}{$\begin{array}{c}\text { Percentual } \\
\text { Válido }\end{array}$} & $\begin{array}{c}\text { Percentual } \\
\text { Acumulativo }\end{array}$ \\
\hline Válido & Lasca & 91 & 45,0 & 45,0 & 45,0 \\
& Fragmento & 84 & 41,6 & 41,6 & 86,6 \\
& Fragmento de Lasca & 27 & 13,4 & 13,4 & 100,0 \\
Total & 202 & 100,0 & 100,0 & \\
\hline
\end{tabular}


Tabela 145 - Classe de Lasca

Classe de Lasca

\begin{tabular}{|ll|r|r|r|r|}
\hline & Frequência & Percentual & $\begin{array}{c}\text { Percentual } \\
\text { Válido }\end{array}$ & $\begin{array}{c}\text { Percentual } \\
\text { Acumulativo }\end{array}$ \\
\hline Válido & Simples & 31 & 15,3 & 34,1 & 34,1 \\
& Siret & 7 & 3,5 & 7,7 & 41,8 \\
& Inicial & 10 & 5,0 & 11,0 & 52,7 \\
& Flanco de Núcleo & 2 & 1,0 & 2,2 & 54,9 \\
& Preparo de Núcleo & 19 & 9,4 & 20,9 & 75,8 \\
& Descorticamento & 12 & 5,9 & 13,2 & 89,0 \\
& Acabamento & 6 & 3,0 & 6,6 & 95,6 \\
& Retoque & 4 & 2,0 & 4,4 & 100,0 \\
Ausente & Sistema & 91 & 45,0 & 100,0 & \\
Total & Total & 111 & 55,0 & & \\
\hline
\end{tabular}

Tabela 146 - Percussão

Percussão

\begin{tabular}{|ll|r|r|r|r|}
\hline & Frequência & Percentual & $\begin{array}{c}\text { Percentual } \\
\text { Válido }\end{array}$ & $\begin{array}{c}\text { Percentual } \\
\text { Acumulativo }\end{array}$ \\
\hline Válido & Direta Dura & 87 & 43,1 & 95,6 & 95,6 \\
& Não Identificada & 4 & 2,0 & 4,4 & 100,0 \\
& Total & 91 & 45,0 & 100,0 & \\
Ausente & Sistema & 111 & 55,0 & & \\
Total & & 202 & 100,0 & & \\
\hline
\end{tabular}


Tabela 147 - Preparo de Talão

Preparo de talão

\begin{tabular}{|ll|r|r|r|r|}
\hline & Frequência & Percentual & \multicolumn{1}{c|}{$\begin{array}{c}\text { Percentual } \\
\text { Válido }\end{array}$} & $\begin{array}{c}\text { Percentual } \\
\text { Acumulativo }\end{array}$ \\
\hline Válido & Sim & 10 & 5,0 & 11,0 & 11,0 \\
& Não & 81 & 40,1 & 89,0 & 100,0 \\
& Total & 91 & 45,0 & 100,0 & \\
Ausente & Sistema & 111 & 55,0 & & \\
Total & & 202 & 100,0 & & \\
\hline
\end{tabular}

Tabela 148 - Classe de Talão

Classe de Talão

\begin{tabular}{|ll|r|r|r|r|}
\hline & Frequência & Percentual & \multicolumn{1}{c|}{$\begin{array}{c}\text { Percentual } \\
\text { Válido }\end{array}$} & $\begin{array}{c}\text { Percentual } \\
\text { Acumulativo }\end{array}$ \\
\hline Válido & Cortical & 25 & 12,4 & 27,5 & 27,5 \\
& Liso & 54 & 26,7 & 59,3 & 86,8 \\
& Facetado & 3 & 1,5 & 3,3 & 90,1 \\
& Linear & 5 & 2,5 & 5,5 & 95,6 \\
& Esmigalhado & 3 & 1,5 & 3,3 & 98,9 \\
& Outros & 1 &, 5 & 1,1 & 100,0 \\
Ausente & Sotal & 91 & 45,0 & 100,0 & \\
Total & & 111 & 55,0 & & \\
\hline
\end{tabular}


Tabela 149 - Espessura do Talão

Espessura do talão

\begin{tabular}{|l|r|r|r|r|r|}
\hline & \multicolumn{1}{|c|}{ N } & \multicolumn{1}{|c|}{ Mínimo } & Máximo & Média & \multicolumn{1}{c|}{ Desvio Padrão } \\
\hline Espessura Talão & 88 & 1 & 25 & 6,49 & 5,237 \\
Válido N & 88 & & & & \\
\hline
\end{tabular}

Tabela 150 - Ângulo do talão com a face interna da lasca

Ângulo do Talão com a Face Interna da Lasca

\begin{tabular}{|ll|r|r|r|r|}
\hline & Frequência & Percentual & $\begin{array}{c}\text { Percentual } \\
\text { Válido }\end{array}$ & $\begin{array}{c}\text { Percentual } \\
\text { Acumulativo }\end{array}$ \\
\hline Válido & 70 & 4 & 2,0 & 4,9 & 4,9 \\
& 80 & 17 & 8,4 & 20,7 & 25,6 \\
& 90 & 38 & 18,8 & 46,3 & 72,0 \\
& 100 & 15 & 7,4 & 18,3 & 90,2 \\
& 110 & 8 & 4,0 & 9,8 & 100,0 \\
Ausente & Sistema & 120 & 59,4 & 100,0 & \\
Total & & 202 & 100,0 & & \\
\hline
\end{tabular}


Tabela 151 - Número de retiradas da face externa da lasca

Número de Retiradas da Face Externa da Lasca

\begin{tabular}{|ll|r|r|r|r|}
\hline & Frequência & Percentual & $\begin{array}{c}\text { Percentual } \\
\text { Válido }\end{array}$ & $\begin{array}{c}\text { Percentual } \\
\text { Acumulativo }\end{array}$ \\
\hline Válido & 1 & 58 & 28,7 & 63,7 & 63,7 \\
& 2 & 23 & 11,4 & 25,3 & 89,0 \\
& 3 & 10 & 5,0 & 11,0 & 100,0 \\
& Total & 91 & 45,0 & 100,0 & \\
Ausente & Sistema & 111 & 55,0 & & \\
Total & 202 & 100,0 & & \\
\hline
\end{tabular}

Tabela 152 - Medidas das lascas e fragmentos das lascas

Medidas das Lascas e Fragmentos das Lascas

\begin{tabular}{|l|r|r|r|r|r|}
\hline & \multicolumn{1}{|c|}{ N } & \multicolumn{1}{|c|}{ Mínimo } & Máximo & \multicolumn{1}{c|}{ Média } & \multicolumn{1}{c|}{ Desvio Padrão } \\
\hline Comprimento & 118 & 4 & 77 & 28,88 & 14,273 \\
Largura & 118 & 5 & 60 & 25,02 & 12,129 \\
Espessura & 118 & 2 & 95 & 9,77 & 10,195 \\
Válido N (listwise) & 116 & & & & \\
\hline
\end{tabular}




\section{Conjunto 1 de Rocha Verde}

Tabela 153 - Suporte

\section{Suporte}

\begin{tabular}{|ll|r|r|r|r|}
\hline & Freauência & Percentual & $\begin{array}{c}\text { Percentual } \\
\text { Válido }\end{array}$ & $\begin{array}{c}\text { Percentual } \\
\text { Acumulativo }\end{array}$ \\
\hline Válido & Seixo & 8 & 3,8 & 3,8 & 3,8 \\
& Bloco & 152 & 72,7 & 72,7 & 76,6 \\
& Não identificado & 49 & 23,4 & 23,4 & 100,0 \\
& 209 & 100,0 & 100,0 & \\
\hline
\end{tabular}

Tabela 154 - Córtex

Córtex

\begin{tabular}{|rl|r|r|r|r|}
\hline & Frequência & Percentual & \multicolumn{1}{c|}{$\begin{array}{c}\text { Percentual } \\
\text { Válido }\end{array}$} & $\begin{array}{c}\text { Percentual } \\
\text { Acumulativo }\end{array}$ \\
\hline Válido & não & 183 & 87,6 & 87,6 & 87,6 \\
& sim & 26 & 12,4 & 12,4 & 100,0 \\
& Total & 209 & 100,0 & 100,0 & \\
\hline
\end{tabular}

Tabela 155 - Classe

Classe

\begin{tabular}{|ll|r|r|r|r|}
\hline & Frequência & Percentual & $\begin{array}{c}\text { Percentual } \\
\text { Válido }\end{array}$ & $\begin{array}{c}\text { Percentual } \\
\text { Acumulativo }\end{array}$ \\
\hline Válido & Lasca & 70 & 33,5 & 33,5 & 33,5 \\
& Fragmento & 88 & 42,1 & 42,1 & 75,6 \\
& Fragmento de lasca & 25 & 12,0 & 12,0 & 87,6 \\
& Fragmento de seixo & 1 &, 5 &, 5 & 88,0 \\
& Fragmento de Polido & 25 & 12,0 & 12,0 & 100,0 \\
Total & 209 & 100,0 & 100,0 & \\
\hline
\end{tabular}


Tabela 156 - Classe de Lasca

Classe de Lasca

\begin{tabular}{|ll|r|r|r|r|}
\hline & & Frequência & Percentual & $\begin{array}{c}\text { Percentual } \\
\text { Válido }\end{array}$ & $\begin{array}{c}\text { Percentual } \\
\text { Acumulativo }\end{array}$ \\
\hline Válido & Simples & 32 & 15,3 & 45,7 & 45,7 \\
& Com Dorso & 3 & 1,4 & 4,3 & 50,0 \\
& Preparo de Núcleo & 15 & 7,2 & 21,4 & 71,4 \\
& Descorticamento & 11 & 5,3 & 15,7 & 87,1 \\
& Acabamento & 8 & 3,8 & 11,4 & 98,6 \\
& Retoque & 1 &, 5 & 1,4 & 100,0 \\
& Total & 70 & 33,5 & 100,0 & \\
Ausência & Sistema & 139 & 66,5 & & \\
Total & 209 & 100,0 & & \\
\hline
\end{tabular}

Tabela 157 - Percussão

Percussão

\begin{tabular}{|c|r|r|r|r|}
\hline & Frequência & Percentual & Percentual Váli & $\begin{array}{c}\text { Percentual } \\
\text { Acumulativo }\end{array}$ \\
\hline Válido Direta Dura & 49 & 23,4 & 70,0 & 70,0 \\
N. Identificada & 21 & 10,0 & 30,0 & 100,0 \\
Total & 70 & 33,5 & 100,0 & \\
Ausência Sistema & 139 & 66,5 & & \\
Total & 209 & 100,0 & & \\
\hline
\end{tabular}

Tabela 158 - Preparo de Talão

Preparo de talão

\begin{tabular}{|ll|r|r|r|r|}
\hline & & Freauência & Percentual & Percentual Vál & $\begin{array}{l}\text { Percentual } \\
\text { Acumulativo }\end{array}$ \\
\hline Válido & Sim & 11 & 5,3 & 15,7 & 15,7 \\
& Não & 59 & 28,2 & 84,3 & 100,0 \\
& Total & 70 & 33,5 & 100,0 & \\
Ausência & Sistema & 139 & 66,5 & & \\
Total & 209 & 100,0 & & \\
\hline
\end{tabular}


Tabela 159 - Classe de Talão

\begin{tabular}{|c|c|c|c|c|c|}
\hline & & Freauência & Percentual & $\begin{array}{l}\text { Percentual } \\
\text { Válido }\end{array}$ & $\begin{array}{l}\text { Percentual } \\
\text { Acumulativo }\end{array}$ \\
\hline \multirow[t]{7}{*}{ Válido } & Cortical & 1 &, 5 & 1,4 & 1,4 \\
\hline & Liso & 57 & 27,3 & 81,4 & 82,9 \\
\hline & Diedro & 2 & 1,0 & 2,9 & 85,7 \\
\hline & Facetado & 3 & 1,4 & 4,3 & 90,0 \\
\hline & Linear & 4 & 1,9 & 5,7 & 95,7 \\
\hline & smigalhado & 3 & 1,4 & 4,3 & 100,0 \\
\hline & Total & 70 & 33,5 & 100,0 & \\
\hline \multirow{2}{*}{\multicolumn{2}{|c|}{$\begin{array}{l}\text { Ausência Sistema } \\
\text { Total }\end{array}$}} & 139 & 66,5 & & \\
\hline & & 209 & 100,0 & & \\
\hline
\end{tabular}

Tabela 160 - Espessura do Talão

Espessura de Talão

\begin{tabular}{|l|r|r|r|r|r|}
\hline & \multicolumn{1}{|c|}{ N } & \multicolumn{1}{c|}{ Mínimo } & Máximo & Média & Desvio Padrão \\
\hline Espessura Talão & 87 & 1 & 100 & 7,31 & 11,839 \\
Válido N & 87 & & & & \\
\hline
\end{tabular}


Tabela 161 - Ângulo do talão com a face interna da lasca

Ângulo do talão com a face interna da lasca

\begin{tabular}{|ll|r|r|r|r|}
\hline & & Frequência & Percentual & $\begin{array}{l}\text { Percentual } \\
\text { Válido }\end{array}$ & $\begin{array}{l}\text { Percentual } \\
\text { Acumulativo }\end{array}$ \\
\hline Válido & 70 & 1 &, 5 & 2,9 & 2,9 \\
& 80 & 5 & 2,4 & 14,7 & 17,6 \\
& 90 & 13 & 6,2 & 38,2 & 55,9 \\
& 100 & 6 & 2,9 & 17,6 & 73,5 \\
& 110 & 6 & 2,9 & 17,6 & 91,2 \\
& 120 & 3 & 1,4 & 8,8 & 100,0 \\
& Total & 34 & 16,3 & 100,0 & \\
Ausência & Sistema & 175 & 83,7 & & \\
Total & 209 & 100,0 & & \\
\hline
\end{tabular}

Tabela 162 - Número de retiradas da face externa da lasca

Número de retiradas da face externa da lasca

\begin{tabular}{|ll|r|r|r|r|}
\hline & & Frequência & Percentual & $\begin{array}{l}\text { Percentual } \\
\text { Válido }\end{array}$ & $\begin{array}{l}\text { Percentual } \\
\text { Acumulativo }\end{array}$ \\
\hline Válido & 1 & 28 & 13,4 & 40,0 & 40,0 \\
& 2 & 22 & 10,5 & 31,4 & 71,4 \\
& 3 & 15 & 7,2 & 21,4 & 92,9 \\
& 4 & 5 & 2,4 & 7,1 & 100,0 \\
& Total & 70 & 33,5 & 100,0 & \\
Ausência & Sistema & 139 & 66,5 & & \\
Total & 209 & 100,0 & & \\
\hline
\end{tabular}

Tabela 163 - Medidas das lascas e fragmentos das lascas

Medidas de lascas e fragmentos de lascas

\begin{tabular}{|l|r|r|r|r|r|}
\hline & \multicolumn{1}{|c|}{ N } & Mínimo & Máximo & Média & Desvio Padrão \\
\hline Comprimento & 95 & 4 & 125 & 31,41 & 20,669 \\
Largura & 95 & 7 & 115 & 30,96 & 19,745 \\
Espessura & 95 & 2 & 30 & 7,93 & 5,545 \\
Válido N(listwise) & 95 & & & & \\
\hline
\end{tabular}




\section{Conjunto 1 de Óxido de Ferro}

Tabela 164 - Suporte

Suporte

\begin{tabular}{|ll|r|r|r|r|}
\hline & Frequência & Percentual & $\begin{array}{c}\text { Percentual } \\
\text { Válido }\end{array}$ & $\begin{array}{c}\text { Percentual } \\
\text { Acumulativo }\end{array}$ \\
\hline Válido & Seixo & 81 & 23,8 & 23,8 & 23,8 \\
& Não Identificado & 115 & 33,7 & 33,7 & 57,5 \\
& Plaqueta & 145 & 42,5 & 42,5 & 100,0 \\
Total & 341 & 100,0 & 100,0 & \\
\hline
\end{tabular}

Tabela 165 - Classe

Classe

\begin{tabular}{|c|r|r|r|r|}
\hline & Frequência & Percentual & P. Válido & $\begin{array}{c}\text { Percentual } \\
\text { Acumulativo }\end{array}$ \\
\hline Válido Lasca & 25 & 7,3 & 7,3 & 7,3 \\
Fragmento & 72 & 21,1 & 21,1 & 28,4 \\
Seixo n. usado & 71 & 20,8 & 20,8 & 49,3 \\
Frag. Térmico & 4 & 1,2 & 1,2 & 50,4 \\
Frag de Lasca & 4 & 1,2 & 1,2 & 51,6 \\
Frag de Seixo & 5 & 1,5 & 1,5 & 53,1 \\
Plaqueta n. usa fla & 120 & 35,2 & 35,2 & 88,3 \\
Frag. usados & 40 & 11,7 & 11,7 & 100,0 \\
Total & 341 & 100,0 & 100,0 & \\
\hline
\end{tabular}

Tabela 166 - Classe de lasca

Classe de lasca

\begin{tabular}{|r|r|r|r|r|}
\hline & Frequência & Percentual & P. Válido & $\begin{array}{r}\text { Percentual } \\
\text { Acumulativo }\end{array}$ \\
\hline Válido Simples & 14 & 4,1 & 56,0 & 56,0 \\
Descorticamento & 3 &, 9 & 12,0 & 68,0 \\
Acabamento & 7 & 2,1 & 28,0 & 96,0 \\
Retoque & 1 &, 3 & 4,0 & 100,0 \\
Total & 25 & 7,3 & 100,0 & \\
Ausência Sistema & 316 & 92,7 & & \\
Total & 341 & 100,0 & & \\
\hline
\end{tabular}


Tabela 167 - Percussão

Percussão

\begin{tabular}{|l|r|r|r|r|}
\hline & Frequência & Percentual & P. Válido & $\begin{array}{l}\text { Percentual } \\
\text { Acumulativo }\end{array}$ \\
\hline Válido Direta Dura & 25 & 7,3 & 100,0 & 100,0 \\
Ausência Sistema & 316 & 92,7 & & \\
Total & 341 & 100,0 & & \\
\hline
\end{tabular}

Tabela 168 - Preparo de Talão

Preparo de talăo

\begin{tabular}{|c|c|c|c|c|c|}
\hline & & Frequência & Percentual & P. Válido & $\begin{array}{l}\text { Percentual } \\
\text { Acumulativo }\end{array}$ \\
\hline \multirow[t]{3}{*}{ Válido } & Sim & 7 & 2,1 & 28,0 & 28,0 \\
\hline & Não & 18 & 5,3 & 72,0 & 100,0 \\
\hline & Total & 25 & 7,3 & 100,0 & \\
\hline \multirow{2}{*}{$\begin{array}{l}\text { Ausência } \\
\text { Total }\end{array}$} & Sistema & 316 & 92,7 & & \\
\hline & & 341 & 100,0 & & \\
\hline
\end{tabular}

Tabela 169 - Classe de Talão

Classe de Talão

\begin{tabular}{|rr|r|r|r|r|}
\hline & & Frequência & Percentual & $\begin{array}{c}\text { Percentual } \\
\text { Válido }\end{array}$ & $\begin{array}{l}\text { Percentual } \\
\text { Acumulativo }\end{array}$ \\
\hline Válido & Simples & 19 & 5,6 & 76,0 & 76,0 \\
& Diedro & 1 &, 3 & 4,0 & 80,0 \\
& Linear & 2 &, 6 & 8,0 & 88,0 \\
Esmigalhado & 1 &, 3 & 4,0 & 92,0 \\
& Outros & 2 &, 6 & 8,0 & 100,0 \\
& Total & 25 & 7,3 & 100,0 & \\
Ausência & Sistema & 316 & 92,7 & & \\
Total & 341 & 100,0 & & \\
\hline
\end{tabular}


Tabela 170 - Espessura do Talão

Espessura do talão

\begin{tabular}{|l|r|r|r|r|r|}
\hline & \multicolumn{1}{|c|}{$\mathrm{N}$} & \multicolumn{1}{|c|}{ Mínimo } & Máximo & Média & D. Padrão \\
\hline Espessura Talão & 24 & 1 & 17 & 5,12 & 4,086 \\
Válidc $\mathbb{N}$ & 24 & & & & \\
\hline
\end{tabular}

Tabela 171 - Medidas

Medidas de todas as classes

\begin{tabular}{|l|r|r|r|r|r|}
\hline & \multicolumn{1}{|c|}{ N } & \multicolumn{1}{|c|}{ Minimo } & Máximo & \multicolumn{1}{c|}{ Média } & \multicolumn{1}{c|}{ D. Padrão } \\
\hline Comprimento & 341 & 5 & 77 & 21,16 & 11,452 \\
Largura & 341 & 5 & 95 & 25,08 & 13,566 \\
Espessura & 341 & 1 & 68 & 8,87 & 7,237 \\
Valid N (listwise) & 341 & & & & \\
\hline
\end{tabular}




\section{APÊNDICE IV}

Tabela 172 - Distribuição da frequência de materiais nas quadras

\begin{tabular}{|c|c|c|c|c|}
\hline Quadra & Frequência & Percentual & $\begin{array}{l}\text { Percentual } \\
\text { Válido }\end{array}$ & $\begin{array}{l}\text { Percentual } \\
\text { Acumulativo }\end{array}$ \\
\hline $7 \mathrm{M}$ & 111 & 2,6 & 2,6 & 2,6 \\
\hline $9 \mathrm{~L}$ & 129 & 3,0 & 3,0 & 5,6 \\
\hline $10 \mathrm{~A}$ & 75 & 1,8 & 1,8 & 7,4 \\
\hline $10 \mathrm{~K}$ & 90 & 2,1 & 2,1 & 9,5 \\
\hline 111 & 11 &, 3 & 3 & 9,8 \\
\hline $11 \mathrm{~J}$ & 25 &, 6 & 6 & 10,4 \\
\hline $11 \mathrm{~K}$ & 94 & 2,2 & 2,2 & 12,6 \\
\hline $11 \mathrm{~L}$ & 383 & 9,0 & 9,0 & 21,6 \\
\hline $11 \mathrm{~s}$ & 1 &, 0 &, 0 & 21,6 \\
\hline 121 & 1 &, 0 &, 0 & 21,6 \\
\hline $12 \mathrm{~J}$ & 14 &, 3 & 3 & 22,0 \\
\hline $12 \mathrm{~K}$ & 10 &, 2 &, 2 & 22,2 \\
\hline $12 \mathrm{~L}$ & 321 & 7,5 & 7,5 & 29,7 \\
\hline $12 \mathrm{M}$ & 210 & 4,9 & 4,9 & 34,7 \\
\hline $13 \mathrm{C}$ & 1 &, 0 &, 0 & 34,7 \\
\hline $13 \mathrm{D}$ & 1 &, 0 & 0 & 34,7 \\
\hline $13 \mathrm{~F}$ & 1 &, 0 & 0 & 34,8 \\
\hline $13 \mathrm{G}$ & 14 &, 3 &, 3 & 35,1 \\
\hline $13 \mathrm{H}$ & 29 & .7 & .7 & 35,8 \\
\hline $13 \mathrm{I}$ & 90 & 2,1 & 2,1 & 37,9 \\
\hline $13 \mathrm{~J}$ & 201 & 4,7 & 4,7 & 42,6 \\
\hline $13 \mathrm{~K}$ & 150 & 3,5 & 3,5 & 46,1 \\
\hline $13 \mathrm{~L}$ & 389 & 9,1 & 9,1 & 55,3 \\
\hline $13 \mathrm{M}$ & 203 & 4,8 & 4,8 & 60,1 \\
\hline $13 \mathrm{~N}$ & 64 & 1,5 & 1,5 & 61,6 \\
\hline 130 & 130 & 3,1 & 3,1 & 64,6 \\
\hline $13 \mathrm{P}$ & 8 &, 2 &, 2 & 64,8 \\
\hline $13 \mathrm{~S}$ & 33 & 8 &, 8 & 65,6 \\
\hline $13 \mathrm{~V}$ & 14 & 3 &, 3 & 65,9 \\
\hline $14 \mathrm{~B}$ & 4 &, 1 &, 1 & 66,0 \\
\hline $14 \mathrm{C}$ & 3 &, 1 &, 1 & 66,1 \\
\hline $14 \mathrm{D}$ & 56 & 1,3 & 1,3 & 67,4 \\
\hline $14 \mathrm{~F}$ & 1 &, 0 &, 0 & 67,4 \\
\hline $14 \mathrm{H}$ & 239 & 5,6 & 5,6 & 73,0 \\
\hline $14 \mathrm{I}$ & 111 & 2,6 & 2,6 & 75,6 \\
\hline $14 \mathrm{~J}$ & 210 & 4,9 & 4,9 & 80,6 \\
\hline $14 \mathrm{~K}$ & 112 & 2,6 & 2,6 & 83,2 \\
\hline $14 \mathrm{~L}$ & 49 & 1,2 & 1,2 & 84,4 \\
\hline $15 \mathrm{H}$ & 56 & 1,3 & 1,3 & 85,7 \\
\hline $15 \mathrm{I}$ & 63 & 1,5 & 1,5 & 87,2 \\
\hline $15 \mathrm{~J}$ & 134 & 3,2 & 3,2 & 90,3 \\
\hline $16 \mathrm{G}$ & 20 & .5 & .5 & 90,8 \\
\hline $16 \mathrm{H}$ & 38 &, 9 &, 9 & 91,7 \\
\hline $16 \mathrm{I}$ & 249 & 5,9 & 5,9 & 97,5 \\
\hline $16 \mathrm{~J}$ & 31 &, 7 & .7 & 98,3 \\
\hline $17 \mathrm{~B}$ & 34 & 8 & 8 & 99,1 \\
\hline $17 \mathrm{G}$ & 3 &, 1 & 1 & 99,1 \\
\hline $17 \mathrm{H}$ & 35 & 8 & 8 & 100,0 \\
\hline $18 \mathrm{G}$ & 2 &, 0 & 0 & 100,0 \\
\hline Total & 4253 & 100,0 & 100,0 & \\
\hline
\end{tabular}

